VARGA GERGELY

HOSSZÚ TÁVÚ MUNKAKÍNÁLAT, TŐKEKÍNÁLAT ÉS MAKROGAZDASÁGI HATÁSAIK 
Makroökonómia Tanszék

Témavezető: Major Klára, Phd.

(C) Varga Gergely 
Budapesti Corvinus Egyetem

Közgazdaságtani Doktori Iskola

Közgazdaságtani Doktori Program

\section{HOSSZÚ TÁVÚ MUNKAKÍNÁLAT, TŐKEKÍNÁLAT ÉS MAKROGAZDASÁGI HATÁSAIK}

Doktori értekezés

\section{VARGA GERGELY}

Budapest, 2015. 



\section{Tartalomjegyzék}

\begin{tabular}{ll}
\hline Táblázatok jegyzéke & 12
\end{tabular}

\begin{tabular}{|l|l|l|l|l|l}
\hline Arák jegyzéke & 15
\end{tabular}

\begin{tabular}{ll}
\hline 1. Bevezetés & 17
\end{tabular}

1.1. A hosszú távú munka- és tőkekínálat jelentôsége . . . . . . . . . . . 17

1.2. A dolgozat fö eredményei . . . . . . . . . . . . . . . . . . . . . 20

2. Három megtakarítói típus: egy adaptív-evolúciós megközelítés 25

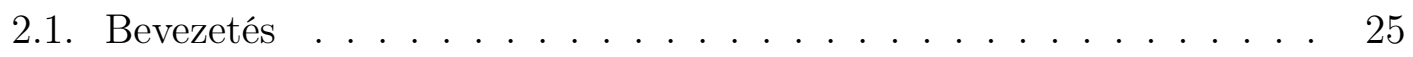

2.2. Megtakarítói típusok . . . . . . . . . . . . . . . . . . 28

2.2.1. A fogyasztás-megtakarítás hagyományos elméletei . . . . . . 28

2.3. Megtakarítási szabályok makro ABM-ekben . . . . . . . . . . . . . 30

2.4. A három típus és versenyük . . . . . . . . . . . . . . . . . . 31

2.5. Egy ABM és szimulációs eredményei . . . . . . . . . . . . . . . . . 32

2.5.1. A modell . . . . . . . . . . . . . . . . . . . . 32 
2.5.2. A szimulációk eredményei . . . . . . . . . . . . . . . . . . 40

2.6. Összegzés . . . . . . . . . . . . . . . . . . . . . . 56

3. Parametrikus nyugdíjreformok és életciklus-munkakínálat 59

3.1. Bevezetés . . . . . . . . . . . . . . . . . . . . . . . . . 59

3.2. A férfiak munkaóráinak korprofiljai 1999 és 2009 között . . . . . . . 64

3.3. Magyar nyugdíjrendszer és munkakínálat . . . . . . . . . . . . . . . 68

3.3.1. Az Öregségi és rokkantsági nyugdíjrendszer munkakínálatra ható elemei 1999 és 2009 között . . . . . . . . . . . . . . . 68

3.3.2. Nyugdíjasok és foglalkoztatottság 1999 és 2009 között . . . . 72

3.4. Az életciklus-munkakínálat modellje . . . . . . . . . . . . . . . . . 76

3.4.1. A háztartások döntési problémája . . . . . . . . . . . . . 77

3.4.2. A háztartás fogyasztási és munkakínálati döntése . . . . . . 80

3.5. A paraméterek értékének megválasztása . . . . . . . . . . . . . . . . 82

3.6. Életciklus-munkakínálat és parametrikus nyugdíjreformok . . . . . . 88

3.7. Következtetések . . . . . . . . . . . . . . . . . . . . . 93

4. Demográfiai átmenet és parametrikus nyugdíjreformok hatása a gazdasági növekedésre és a nyugdíjrendszer fenntarthatóságára $\quad 97$

4.1. Bevezetés . . . . . . . . . . . . . . . . . . . . . . . . . . . . 97

4.2. A nyugdíjrendszer fenntarthatóságát befolyásoló tényezők . . . . . . 99

4.2.1. Demográfiai folyamatok . . . . . . . . . . . . . . . . . 99

6 
Tartalomjegyzék

4.2.2. Munkapiaci aktivitás . . . . . . . . . . . . . . . . . 102

4.2.3. A nyugdíjrendszer . . . . . . . . . . . . . . . 106

4.3. Demográfiai átmenet és a nyugdíjreformok hatásainak szimulációja 108

4.3.1. Nyugdíjreformok fenntarthatóságra gyakorolt hatását vizsgáló ad hoc modellek . . . . . . . . . . . . . . . . . . . . . . 108

4.3.2. Az Auerbach-Kotlikoff típusú modellek általános felépítése . 111

4.3.3. Demográfiai átmenet és nyugdíjreformok szimulációja A-K modellekkel . . . . . . . . . . . . . . . . 116

4.4. Demográfiai átmenet egy kis nyitott gazdaság OLG modelljében . . 121

4.4.1. Demográfia . . . . . . . . . . . . . . . . . . 122

4.4.2. A háztartások döntési problémája . . . . . . . . . . . . . . 122

4.4.3. A háztartások problémájának a megoldása . . . . . . . . . . 126

4.4.4. Vállalatok . . . . . . . . . . . . . . . . . . . . . . . . . . 128

4.4.5. Az állam költségvetése . . . . . . . . . . . . . . . . 129

4.4.6. Egyensúlyi feltételek . . . . . . . . . . . . . . . . . . 130

4.4.7. A modell megoldása . . . . . . . . . . . . . . . . 131

4.4.8. A paraméterek megválasztása és a gazdaság 2006-2010-es állapota . . . . . . . . . . . . . . . . 132

4.4.9. Szimuláció . . . . . . . . . . . . . . . . . 136

4.4.10. Következtetések és továbblépési irányok . . . . . . . . . . . . 152

\begin{tabular}{ll}
\hline 5. Befejezés & 157
\end{tabular} 
6. Hivatkozások

7. Saját publikációk a témában

\begin{tabular}{lr}
\hline 8. Függelék & 177
\end{tabular}

F.1. Ábrák, táblázatok . . . . . . . . . . . . . . . . . . 178

F.2. A háztartás feladatának megoldása . . . . . . . . . . . . . . . 187

F.3. Az együttélő korosztályok modelljének normált egyenletei . . . . . . . 190

F.4. Az effektív munka, a hatékony fơre jutó fogyasztás és vagyon dekompozíciójának módszertana . . . . . . . . . . . . . . . . . . 193 


\section{Táblázatok jegyzéke}

2.1. A rögzített paraméterek értéke . . . . . . . . . . . . . . . . 41

2.2. A kibővített Dickey-Fuller tesztek eredményei $\Upsilon=0,001, \Upsilon=10$ és $\Upsilon=1000$ esetben . . . . . . . . . . . . . . . . . . . . . 44

2.3. Az aggregált tôkeállomány szimulációnkénti átlagainak átlaga, minimuma és maximuma a "hômérséklet" $(\Upsilon)$ különbözố értékei mellett, az aranykori tôkkeállomány százalékában . . . . . . . . . . . . . . . . 45

2.4. Az egyes háztartástípusok (prudens, rövidlátó és permanens jövedelem) arányának szimulációkénti átlagai: az átlagok átlaga, minimuma és maximuma a "hőmérséklet" (؟) különböző értékei mellett . . 49

2.5. Az aggregált fogyasztás szimulációnkénti átlagainak átlaga, minimuma és maximuma a "hốmérséklet" $(\Upsilon)$ különbözố értékei mellett, az aranykori fogyasztás százalékában . . . . . . . . . . . . . . . 50

2.6. A puffer méret szimulációnkénti átlagainak átlaga, minimuma és maximuma a "hốmérséklet" $(\Upsilon)$ különbözó értékei mellett . . . . . . 51

2.7. Az adósságráta $(D / Y)$ szimulációnkénti átlagainak átlaga, minimuma és maximuma a "hőmérséklet" (؟) különböző értékei mellett . . 51 
2.8. Az aggregált tókeállomány szimulációnkénti átlagainak átlaga, minimuma és maximuma a "hőmérséklet" $(\Upsilon)$ különbözó értékei mellett, katasztrófák esetén, az aranykori tôkeállomány százalékában, katasztrófák esetén . . . . . . . . . . . . . . . . . . . . . . 53

2.9. A puffer méret szimulációnkénti átlagainak átlaga, minimuma és maximuma a "hômérséklet" ( $\Upsilon$ különbözô értékei mellett, katasztrófák esetén . . . . . . . . . . . . . . . . . 5 53

2.10. Az egyes háztartástípusok (prudens $(p r)$, rövidlátó $(r l)$ és permanens jövedelem $(p j))$ arányának szimulációkénti átlagai $(\Upsilon=10)$, amikor

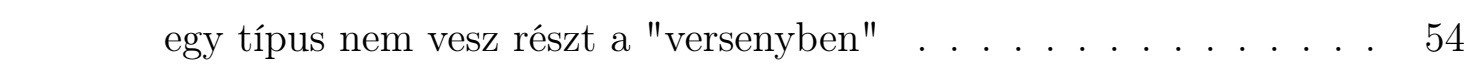

2.11. Az adósságráta $(D / Y)$ szimulációnkénti átlagainak átlaga, minimuma és maximuma a "hômérséklet" ( $\Upsilon$ különbözô értékei mellett alacsony és magas hitelkorlát $(\bar{D})$ mellett . . . . . . . . . . . . . . . 55

2.12. Az aggregált tôkeállomány szimulációnkénti átlagainak átlaga, mini\begin{tabular}{|l|l|}
\hline muma és maximuma a "hốmérséklet" $(\Upsilon)$ különbözô értékei mellett \\
\hline \hline alacsony és magas hitelkorlát $(\bar{D})$ mellett . . . . . . . . . . . . . . . 56
\end{tabular}

3.1. A modell paraméterei . . . . . . . . . . . . . . . . 86

3.2. Becsült preferenciaparaméterek . . . . . . . . . . . . . . 87

3.3. A magas és közepes képzettségú férfiak munkakínálatának százalékos

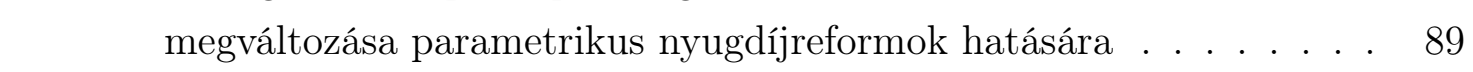

4.1. A modell paraméterei az alapváltozatban . . . . . . . . . . . . . 135

4.2. A hatékony fő́re jutó aggregált változók 2006-10 és 2066-70 közötti változásának dekompozíciója (\%-os változás) . . . . . . . . . . . . . 137

4.3. A hatékony fôre jutó munkakínálat \%-os eltérése az alappályájától 2006-10 és 2066-70 között, parametrikus nyugdíjreformok mellett. . 145 
4.4. A hatékony fơre jutó fogyasztás \%-os eltérése az alappályájától 200610 és 2066-70 között, parametrikus nyugdíjreformok mellett. . . . . 145

4.5. A hatékony főre jutó vagyon \%-os eltérése az alappályájától 2006-10 és 2066-70 között, parametrikus nyugdíjreformok mellett . . . . . . 146

4.6. A hatékony fơre jutó tôkeállomány \%-os eltérése az alappályájától 2006-10 és 2066-70 között, parametrikus nyugdíjreformok mellett. . 146

4.7. A hatékony főre jutó kibocsátás \%-os eltérése az alappályájától 200610 és 2066-70 között, parametrikus nyugdíjreformok mellett. . . . . 147

4.8. A GDP-arányos külsố adósság százalékpontos eltérése az alappályájától 2006-10 és 2066-70 között, parametrikus nyugdíjreformok mellett147

4.9. A reálkamatláb százalékpontos eltérése az alappályájától 2006-10 és 2066-70 között, parametrikus nyugdíjreformok mellett . . . . . . . . 148

4.10. A hatékonysági egységre jutó reálbér \%-os eltérése az alappályájától 2006-10 és 2066-70 között, parametrikus nyugdíjreformok mellett. . 148

4.11. A GDP-arányos nyugdíjkiadások alakulása a parametrikus nyugdíjreformok mellett . . . . . . . . . . . . . . . . . . . . . . . . . 150

4.12. A nyugdíjrendszer GDP-arányos hiánya 2006-10 és 2066-70 között parametrikus nyugdíjreformok mellett . . . . . . . . . . . . . . 151

4.13. A fogyasztási adó kulcsa 2006-10 és 2066-70 között parametrikus nyugdíjreformok mellett . . . . . . . . . . . . . . . . . . . 151

4.14. Az 1951-55 és 2006-10 között született kohorszok 60 éves korban várható nyugdíjának jelenértéke a reálbérhez viszonyítva: \%-os eltérés

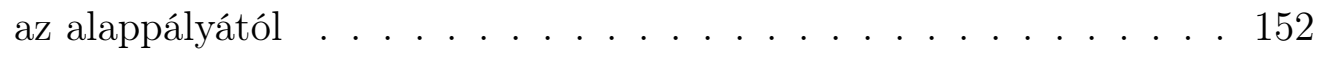

8.1. A munkakínálat százalékos megváltozása a parametrikus nyugdíjreformok hatására az egyes korosztályokban. 3 képzettségi csoport . . 180 
8.2. Termelékenységi profil becslése - alacsony képzettségüek . . . . . . 180

8.3. Termelékenységi profil becslése - közepes képzettségüek . . . . . . . 182

8.4. Termelékenységi profil becslése - magas képzettségüek . . . . . . . . 184 


\section{Ábrák jegyzéke}

2.1. Az aggregált tókeállomány alakulása $\Upsilon=0,001$ mellett . . . . . . . 46

2.2. Az aggregált tókeállomány alakulása $\Upsilon=10$ mellett . . . . . . . . . 47

2.3. Az aggregált tôkeállomány alakulása $\Upsilon=1000$ mellett . . . . . . . 48

2.4. Az aggregált tókeállomány alakulása $\bar{h}=30$ és $\Upsilon=10$ mellett . . . 52

3.1. Az 55-64 éves korosztály foglalkoztatottsági rátái 2011-ben az Európai Unióban . . . . . . . . . . . . . . . . . . . . . . . . 61

3.2. A férfiak átlagos egy före jutó munkaórái, foglalkoztatottsági rátái és egy munkásra jutó munkaórái, 1999-2009. . . . . . . . . . . . . . 66

3.3. A férfiak átlagos egy főre jutó munkaórái és azok összetevői képzettségi csoportonként, 1999-2009. . . . . . . . . . . . . . . 67

3.4. Nyugdíjas és foglalkoztatott férfiak aránya korosztályonként 2004-ben. 72

3.5. Rokkantsági és öregségi nyugdíjba vonuló férfiak aránya korosztályonként 1999-2009. . . . . . . . . . . . . . . . . . . . . . . 74

3.6. Rokkantsági és öregségi nyugdíjas férfiak aránya korosztályonként, képzettségi csoportonként 1999-2009. . . . . . . . . . . . . . . . 75 
3.7. Rokkantsági és öregségi nyugdíjba vonuló férfiak aránya korosztályonként, képzettségi csoportonként 1999-2009. . . . . . . . . . . . 75

3.8. Alacsony, közepes és magas képzettségú férfiak termelékenységi korprofiljai . . . . . . . . . . . . . . . . . . . 83

3.9. Magas és közepes képzettségúek megfigyelt és becsült foglalkoztatási arányai . . . . . . . . . . . . . . . . . 88

4.1. Az időskori függôségi ráta Magyarországon, 1950-2010. . . . . . . . . 101

4.2. Időskori függôségi ráták előrevetítése Magyarországon, 2001-2100. . 102

4.3. Aktivitási ráta a 20-64 évesek körében a visegrádi országokban, 1998-

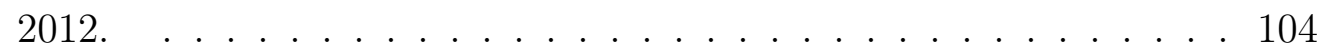

4.4. Aktivitási ráta elôreszámítása Magyarországon, 2001-2100. . . . . . 105

4.5. A népesség megoszlása az egyes korosztályok között a 2006-10-es és a 2066-70-es idôszakában . . . . . . . . . . . . . . . . . . . . . . . . 133

4.6. A 26-60 évesekre jutó 60 évnél idősebbek száma 2006-10 és 2066-70 között . . . . . . . . . . . . . . . . . . . 136

4.7. A demográfiai átmenet hatása a makrováltozókra 2006-10 és 2066-70 |között (1.) . . . . . . . . . . . . . . . . . 139

4.8. A demográfiai átmenet hatása a makrováltozókra 2006-10 és 2066-70

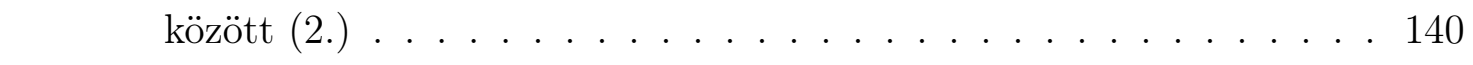

4.9. A demográfiai átmenet hatása az állami költségvetésre 2006-10 és 2066-70 között . . . . . . . . . . . . . . . . . . . . . 141

4.10. Az 1951-55 és 2006-10 között született kohorszok 60 éves korban várható nyugdíjának jelenértéke a reálbérhez viszonyítva: 1951-55ös kohorsz $=100 \%$. . . . . . . . . . . . . . . . . . . . . . . . 142 
Ábrák jegyzéke

8.1. A férfiak átlagos egy főre jutó munkaórái, foglalkoztatottsági rátái és egy munkásra jutó munkaórái 1999., 2004. és 2009. években . 178

8.2. A férfiak átlagos egy főre jutó munkaóráinak, foglalkoztatottsági rátáinak és egy munkásra jutó munkaóráinak arányai képzettségi csoportonként 1999-2009 . . . . . . . . . . . . . . . . . . . . . . . . . . 179

8.3. Nyugdíjas és foglalkoztatott férfiak aránya korosztályonként 1999. és 2009. években . . . . . . . . . . . . . . . . . . . . . . . . . . . . 179

8.4. Rokkantsági és öregségi nyugdíjba vonuló férfiak aránya korosztályonként az 1999., 2004. és 2009. években . . . . . . . . . . . . . 180 


\section{1. fejezet}

\section{Bevezetés}

\subsection{A hosszú távú munka- és tôkekínálat jelentősége}

A makroökonómia területét az alapszintú tankönyvek hagyományosan hosszú és rövid távra osztják. Konszenzusos vélemény, hogy az üzleti ciklusok elemzésénél nem lehet eltekinteni a nominális ár- és bérmerevségektől (rövid táv), és így a gazdaság mozgását nagyban befolyásolják az aggregált kereslet komponenseit érô sokkok. Amennyiben azonban ennél hosszabb távú jelenségeket szeretnénk modellezni, a merevségek jelenlétét nem szükséges figyelembe venni, feltehető, hogy az árak és bérek rugalmasan alkalmazkodnak (hosszú táv), így a gazdasági események kínálati oldalról meghatározottak ${ }^{1}$

Azok a közgazdászok, akik a gazdaságok hosszú távú teljesítményét szeretnék megérteni, az intézmények (például Acemoglu, Johnson, Robinson [2005]) hatásainak vizsgálata mellett hagyományosan a technológiai haladás mechanizmusával (például Romer [1990]) és - ahogy jelen tanulmány is - a termelési tényezôk kíná-

\footnotetext{
${ }^{1}$ Kivételt képeznek azok a modellek, ahol növekvô mérethozadék jellemzi a vállalatok technológiáját, és a keresleti oldal is meghatározza a gazdaság hosszú távú egyensúlyát: például az új gazdaságföldrajz modelljei (Krugman [1991]), a "big push" elméletei (Murphy, Shleifer, Vishny [1989]) vagy a szegénységi csapda modelljei (Azariadis, Stachurski [2005])
} 
latát meghatározó folyamatokkal foglalkoznak. Az alábbiakban a tanulmány saját eredményeinek ismertetését megelôzően röviden bemutatok néhány fontos stilizált tényt a két legfontosabb termelési tényezô, a munka és a tôke kínálatának hosszú távú alakulásáról, ismertetek néhány olyan tanulmányt, elméletet, amelyek magyarázatot szolgáltatnak az alakulásukra, illetve arra, hogy milyen (makrogazdasági és költségvetési) hatásaik vannak.

Greenwood, Vandenbroucke [2005] kiemeli, hogy az elmúlt 200 évben az egy munkásra jutó (piacon) ledolgozott órák száma csökkenő trendet mutat: az átlagos munkahét hossza 1830-ban még 70, 2002-ben 41 órás volt. A trend okaként a technológiai haladást, a növekvő reálbérek vagyonhatását, a szabadidő fokozódó értékét és a háztartási munka csökkenő munkaidőigényét emeli ki. A közelebbi múltat elemezve Blundell, Bozio, Laroque [2011] bemutatja, hogy az egy foore jutó munkaórák számában 1968-ban még alig volt különbség Franciaország, az Egyesült Királyság és az Amerikai Egyesült Államok között, de 2008-ra több, mint 30 \%-os eltérés alakult ki közöttük. Általában a munkakínálat változásait a reálbérek, az adóés transzferrendszer ösztönző hatásaival hozzák összefüggésbe (pl. Keane [2011], Benczúr, Kátay, Kiss [2012]). Sokan a nyugdíjrendszer és a demográfiai folyamatok jelentőségét emelték ki a csökkenő munkakínálat (és a nyugdíjrendszer reformjait az utóbbi idôkben megfigyelt élénkülés) okaként. A fejlett országok felosztó-kiróvó elven múködő társadalombiztosítási nyugdíjrendszerei a legutóbbi idôk reformjait megelőző időszakban gyakran igen nagyvonalúan múködtek, és kimutathatóan (lásd Gruber, Wise szerk. [2002]) fékezték a munkakínálatot, különösen idôsebb korban. Wallenius [2013] általános egyensúlyi modelljének eredményei szerint az egyes országok eltérô nyugdíjrendszerei jól magyarázzák az életpálya-munkakínálat kései (55 és 64 év közötti) szakaszának eltéréseit. A demográfiai átmenet, melynek során a fejlett gazdaságok népességének egyre nagyobb hányada válik időssé, szintén az összes ledolgozott óra csökkenésével járhat, amennyiben a várható élettartam emelkedését nem kíséri párhuzamosan az egészségben, munkaképesen eltölthető éveknek az emelkedése. Az öregedésnek, az egészségnek, a vagyonnak és a béreknek az életciklus-munkakínálatra és a nyugdíjba vonulásra gyakorolt hatását Rust, Phelan [1997] és French [2005] modellezte. 
A változó munkakínálat jelentôségét a hagyományos növekedéselméletek legtöbbször figyelmen kívül hagyják, és inkább az üzleti ciklusok elméletében játszik központi szerepet (például Hansen [1985]). A növekedési perspektívákra gyakorolt hatás mellett a hazai irodalomban igen nagy teret kapott az a probléma is, hogy a népesség munkakínálati-foglalkoztatottsági viszonyainak kedvezôtlen alakulása milyen hatást gyakorol a felosztó-kiróvó elven múködő nyugdíjrendszer, és általában a költségvetés finanszírozási szükségletére (Orbán, Palotai [2005], Holtzer szerk. [2010]). A nyugdíjrendszer ösztönzőire reagáló munkakínálat (és tôkekínálat) növekedési és költségvetési hatásait legtöbbször az Auerbach és Kotlikoff [1987] modellezési hagyományain nyugvó, együttélő korosztályokat tartalmazó modellek számszerúsítik (például Börsch-Supan, Ludwig [2010], Imrohoroglu, Kitao [2010] vagy Magnani [2011]).

A hosszú távú tókekínálatban, a megtakarítási rátákban nehéz a munkakínálathoz hasonló trendet felfedezni: bár a fejlett országokban a megtakarítási ráták a válságot megelőző években inkább csökkentek, összességében a megtakarítási ráták időszakonként és az országok közötti is nagyon változékonyak. Léteznek országok negatív megtakarítási rátával, és olyanok is, ahol az meghaladja az egyharmadot. Az Egyesült Államokban az 1980-as évek elején még körülbelül 10 \% volt a magán megtakarítások rátája, ami aztán negatívvá vált a XXI. század elejére. A megtakarítási és vagyonfelhalmozási viselkedés magyarázatában fontos szerepet játszik az egyének közötti heterogenitás. A népesség egyik kézenfekvô megbontása a megtakarítások szempontjából Modigliani, Brumberg [1954] óta az életciklus szerint történik: a fiatalok és idősek megtakarítási viselkedése pusztán azért különbözik, mert más szakaszait élik életüknek, és tervezett fogyasztási szintjükhöz képest más jövedelmeket realizálnak. Jövedelmeiket a fejlett országokban nagyban befolyásolja az is, hogy az állam fontos szerepet vállal idôs korukban a társadalombiztosítási nyugdíjrendszer keretében korábbi jövedelmeik - legalább részleges - pótlásában, ez pedig visszahat megtakarítási viselkedésükre (pl. Feldstein [1995]) . Egy másik megközelítés az egyéneket (háztartásokat) két csoportra osztja: egyrészt vannak, akik a hosszú távon hasznosságot maximalizáló fogyasztó eredetileg Irving Fisher [1930] által megfogalmazott elméletének megfelelôen cselekszenek (racionális ágensek), és azok, akik - látszólag - rövid látó módon mindig annyit fogyasztanak, 
amennyit csak tudnak. A különböző elméletek az utóbbiakat illetôen lényegében abban különböznek, hogy minek tudják be ezt a viselkedést: rövidlátásnak (Laibson [1997]), egyszerú irracionalitásnak, vagy likviditási (hitel) korlátoknak (Hall, Mishkin [1982]). Az előretekintő viselkedés modellezésének később egy másik fajtája is elterjedt, amely már a jövedelem nem-diverzifikálható kockázatát és a fogyasztók kockázatviselő képességét is figyelembe veszi (Carroll [1996]). A puffer modell szerint a prudens preferenciákkal rendelkező, viszonylag jelentős nem diverzifikálható munkajövedelem kockázattal bíró háztartások viselkedését az jellemzi, hogy egy vagyon puffer fenntartására törekszenek, amelyet a vagyon/jövedelem aránnyal lehet jellemezni.

A megtakarítási ráta és a jövedelem szintje közötti kapcsolat szinte általánosan elfogadott tézis a növekedési elméletben (például Solow [1956], Diamond [1965]), és az endogén növekedési elméletek gyakran vezetnek arra a konklúzióra, hogy a megtakarítási rátának növekedési hatásai is vannak (például Rebelo [1991]). Akerlof, Shiller [2009] arról ír, hogy a megtakarítási ráták tekintetében milyen óriásiak az egyéni különbségek, amelyek aztán hatalmas eltéréseket okoznak a nyugdíjasok vagyoni helyzetében. A megtakarási ráta változásai (a relatív árváltozásokkal együtt) a nemzeti vagyonnak is számottevô változásait okozhatja (Piketty [2014]), amely részben az adott ország fizikai tôkeállományának, részben a külsô pozíciójának változásában ölt testet. A korábban említett együttélő korosztályok tartalmazó modellek közül több is számszerúsíti az egyes országok eltérő ütemú népességöregedési folyamatainak és nyugdíjreformjainak (és az ezek által kiváltott tókekínálati reakcióknak) a külsố eladósodására gyakorolt hatását (pl. Fehr, Haider, Jokisch [2005]).

\subsection{A dolgozat fó eredményei}

Az értekezés három önálló tanulmányból áll, melyek témáját összeköti, hogy az elôbb bemutatott irodalomhoz kapcsolódva a hosszú távú munka- és tőkekínálatot befolyásoló tényezôkrôl, és azok makrogazdasági következményeirôl fogalmaz meg gondolatokat. Mindegyik tanulmány saját bevezető résszel rendelkezik, amely 
elhelyezi az egyes tanulmányokat a szakirodalomban, ezért itt, a teljes értekezés bevezető fejezetében csupán utalok az egyes fejezetek által fölvetett problémákra és az eredményekre.

- A közgazdaságtanban az ágens-alapú modellezés egyik viszonylag új alkalmazási területe a makroökonómia. Minden makromodellnek, így az ágens-alapú modelleknek is, fontos része a megtakarítási döntések kezelése. A megtakarítások nem tartoznak az ágens-alapú mikroökonómiai modellek népszerú alkalmazási területei közé, ezért a makromodellezôk a hagyományos megtakarítási elméletekhez nyúltak vissza, és a megtakarítási viselkedések bizonyos leegyszerűsített válfajait, amelyet viselkedési szabályként lehet felfogni, építették be modelljeikbe. A2, fejezetben²]azt kérdezzük, hogy néhány népszerú megtakarítási szabály létét feltételezve egy adaptív-evolúciós megközelítésből endogén módon tudunk-e következtetni ezen szabályok relatív életképességére, illetve arra, hogy milyen társadalmi kimeneteket kapunk, amikor az egyes megtakarítási szabályok versenyeznek egymással. Három típust vezetünk be: egy prudens, egy rövidlátó, és egy a permanens jövedelem elméletnek megfelelően múködő típust. Rendkívül erôs szelekciós nyomás mellett a prudens típus egyértelmúen kiszorítja a másik kettôt. Talán furcsa módon a második legéletképesebbnek a rövidlátó típus túnik, de már közepes szelekciós nyomásnál sem hal ki egyik típus sem. Szokásos tókehatékonyság mellett a prudens típus túlberuházási tendenciát visz a gazdaságba, és a gazdaság az aranykori megtakarítási rátánál magasabbat produkál. A hitelkorlátok oldása még nagyobb túlberuházáshoz vezethet, a hitelek mennyiségének növekedése mellett a tőketulajdonosok, akik itt endogén módon alakulnak ki, mintegy kizsákmányoltatják magukat azokkal, akiknek nincs pozitív tôkejövedelmük. A hosszú távú átlagos fogyasztás szempontjából a típusok kiegyensúlyozott aránya adja a legjobb eredményt, ugyanakkor ez jóval nagyobb ingadozással jár, mint amikor csak prudens típusú háztartások léteznek.

\footnotetext{
${ }^{2}$ A fejezet Varga, Vincze [2015b] szerkesztett változata.
} 
- A 3 . fejezet ${ }^{3}$ a magyar férfiak 1999 és 2009 közötti életciklus átlagos munkaprofiljainak és nyugdíjba vonulási jellemzőinek a bemutatását követően felvázol egy magyar adatokra kalibrált életciklus-munkakínálati modellt, és parametrikus nyugdíjreformok hatását szimulálja a segítségével. Az eredmények szerint a helyettesítési ráta csökkentése, a nyugdíjkorhatár emelése és az indexálás megváltoztatása összességében növeli az egyes képzettségi csoportok munkakínálatát, míg a nyugdíj alapját képezô életpálya-átlagkeresetbe beszámító évek számának megváltozása nem jár jelentős aggregált hatással. A reformok azonban az összevont hatások mellett átcsoportosítják a munkakínálatot a korosztályok között. Hosszú távon a reformok a nyugdíjfelhalmozás életkorral fokozódó marginális ösztönzőinek a gyengülése miatt a munkakínálatot a fiatalabb korosztályok felé tolják el. A helyettesítési ráta csökkentése még a két hatás eredőjeként valamennyi korosztályban emelte a foglalkoztatást, de a korhatáremelés és az átlagolási idôszak növelése csökkentette a reform előtt is dolgozó idősebb munkaképes korosztályok foglalkoztatását. Ezzel együtt a korhatáremelés újabb, korábban egyáltalán nem dolgozó korosztályt vont be a munkaerôpiacra, ezért a 61-65 éves, illetve összességében az 56-65 éves korosztály foglalkoztatása jelentősen nôtt. A másik három reformtól eltérôen az árkövetô indexálás bevezetése minden korosztályban azonos mértékben növelte a foglalkoztatást, hiszen a bevezetése a marginális ösztönzóket nem érintette.

- A 4. fejezet! elsố része felvázolja a magyar nyugdíjrendszer fenntarthatóságát befolyásoló alapvető folyamatokat, bemutatja az együttélő korosztályokat tartalmazó ún. Auerbach-Kotlikoff-típusú modellcsaládot, amely figyelembe veszi a demográfiai átmenet és a nyugdíjreformok hatására megváltozott háztartási viselkedést és azok általános egyensúlyi hatásait, és ismertet néhány demográfiai átmenetet és nyugdíjreformot szimuláló tanulmányt. A második részben megvizsgálja, hogy a demográfiai átmenet hogyan hat a nyugdíjkassza GDP-arányos egyenlegére és a makrováltozók pályájára, illetve meghatározza, hogy egyes parametrikus nyugdíjreformok hogyan módosítják a hatásokat.

\footnotetext{
${ }^{3}$ A fejezet Major, Varga [2013] szerkesztett változata.

${ }^{4}$ A fejezet Varga [2014a] és Varga [2014b] szerkesztett változata.
} 
Elemzési keretül egy kis nyitott gazdaság kockázati prémiumot, együttélő korosztályokat tartalmazó neoklasszikus növekedési modellje szolgál, ahol a gazdasági szereplók munkakínálata és megtakarítása reagál a nyugdíjrendszer ösztönzôire.

A szimuláció során a 2006 és 2070 közötti időszakban a magyar népesség szerkezeti átrendezôdése, a munkaképes korú és jelentős vagyonnal rendelkezô háztartások arányának csökkenése önmagában számottevôen mérsékli a hatékony munkakínálatot, a hatékony fốre jutó tôkekínálatot, és az egy fôre jutó GDP-t a technikai haladás által indokolt emelkedéshez képest. Egy dekompozíciós eljárás azonban megmutatja, hogy a kedvezôtlen szerkezeti átalakulások okozta elmaradást mérsékli, hogy a háztartások, reagálva a történtekre növelik munkakínálatukat és több vagyont halmoznak föl. A többletmegtakarítás a külső pozíciót is javítja, a mérséklődő kockázati prémium hatására csökkenő kamatok pedig beruházásokat indukálnak, tôkeintenzívebbé teszik a termelést, ez pedig a reálbérekre is kedvezően hat. Az öregedő társadalomban változatlan nyugdíjparaméterek mellett jelentôsen nônek a GDP-arányos nyugdíjkiadások, a tb-nyugdíjkassza egyenlege 2070-ig a GDP több, mint 10 \%-ával romlik.

Az "egyszerü" parametrikus reformok hosszabb távon megállítani nem, csak lassítani tudják a GDP-arányos kiadásoknak és a tb-hiánynak az emelkedését. A helyettesítési ráta csökkentése, a korhatáremelés és az árindexálás együttes bevezetésének azonnali egyenlegjavító hatása is csak 2041-45-ig képes megtartani a nyugdíjrendszer egyenlegének kiegyensúlyozottságát, járulékemeléssel kiegészülve azonban már egészen 2070-ig képes ellensúlyozni a demográfiai átmenet egyenlegrontó hatását, kezdetben pedig számottevố javuláshoz vezet. Ennek ára, hogy az egyes korosztályok 60 éves korban várt nyugdíjainak jelenértéke a reálbérhez képest minden esetben csökken. Az "összetett" reformok esetén a csökkenés minden érintett korosztály számára számottevő, az alappályához képest akár 36-42\%-os veszteséget is jelenthet, az idôsek jelentôs relatív elszegényedését okozva. A járulékemeléstôl eltekintve a reformok ösztönzik a háztartások munka- és tókekínálatát, és együttes végrehajtásuk hatására az effektív munkaórák száma, a GDP, a fogyasztás és a háztartások 
vagyona nagyobb lehet 2066-70-re az alappálya értékeinél, és a GDP-arányos külső adósság is mérséklődhet. 


\section{2. fejezet}

\section{Három megtakarítói típus: egy adaptív-evolúciós megközelítés}

\subsection{Bevezetés}

Az ágens-alapú modellek (ABM) a közgazdasági modellezés egy olyan sajátos válfaja, amely az utóbbi 20 évben egyfajta alternatívát jelent a hagyományos megközelítésekhez képest számos területen. Ez az új megközelítés részben elméleti (filozófiai) részben pedig matematikai (metodológiai) aspektusokat is magában foglal, ahol ezek az aspektusok összefüggnek egymással. Elméleti szempontból az ABM-ek általában nem tartalmaznak optimalizáló ágenseket, de legalábbis nem tartalmaznak olyanokat, akik esetében az optimalizálás nem fejezhető ki explicit függvény formájában. Tehát az ABM-ek ágensei eleve csak 'kiszámítható" (computable) viselkedéssel rendelkezhetnek (Az ágens alapú modellezésrôl általában lásd Gilbert [2008], Heath et al. [2009], annak elsósorban közgazdasági aspektusairól Tesfatsion [2001], [2006]).

Egy másik filozófiai aspektusa az ABM-eknek a heterogenitás hangsúlyozása. Léteznek hagyományos modellek is, amelyek "sokszereplősek" , ahol a szereplők különböznek egymástól (lásd például az új keynesiánus DSGE modelleket), de 
a heterogenitás egy tipikus ABM-ben "lényegesebb", mint egy végtelen szereplős DSGE-ben, abban az értelemben, hogy nem vezethető le olyan aggregációs szabály (még közelítóleg sem), amely az egyedi viselkedéseket egy aggregált egyenletbe tudná sûríteni. Ennek oka elsôsorban az információ kezelése. Publikus (mindenki számára hozzáférhető, globális) információn alapulnak döntések ABM-ekben is, de szinte minden ABM-ben az ágensek heterogenitása abban is megnyilvánul, hogy jelentôs részben egyedi (lokális) információval rendelkeznek a környezetükról.

Egy fontos további jellemzô, hogy az ABM-ekben nem létezik "racionális várakozás". Logikailag a racionális várakozások (azaz adott információ mellett a jövô "objektív" valószínúség eloszlásának az ismerete) nem következik az információk lokális jellegébôl, sem pedig a "kiszámíthatóság" követelményéból, ám gyakorlatilag lehetetlen olyan nem-triviális modellt alkotni, ahol a racionális várakozások hipotézise "megvalósítható" lenne a fenti követelmények mellett, még ha valaki erre törekedne is.

Matematikailag egy ABM egy általában "nagy" dimenziós nemlineáris differenciaegyenlet-rendszer, amelynek létezik explicit megoldása, és ez az explicit megoldás az, amit a modell egy szimulációja során bizonyos (természetesen véges) időszakra ki is számolunk. Analitikus állítások csak egyszerú ABM-ek esetében fordulnak elő, és ott is inkább közelítések. Ez a metodológia ugyan relatíve új, illetve ritka a közgazdaságtanban, ám korántsem ismeretlen a természettudományokban vagy az ökológiában.

Jóllehet racionális várakozások nincsenek ABM-ekben ezek a modellek sem zárják ki azt, hogy bizonyos döntések a jövôvel kapcsolatos várakozásokon alapuljanak, és azt sem, hogy ezek a várakozások intelligensek legyenek, vagyis hogy a döntéshozók tanuljanak. A tanulási folyamatot igyekeznek azonban a tanulással kapcsolatos pszichológiai tudásunk alapján megfogalmazni, ami kizárja a tökéletességet. (Tanulásról az ágens-alapú modellekben lásd Duffy [2006], Brenner [2006].)

A tanulásnak két válfaját is megkülönböztethetjük egy ágens-alapú modellben. Az egyik fajta (kvantitatív) tanulás azt jelenti, hogy megpróbáljuk előrejelezni a jövedelmünket vagy a jövóbeli hozamokat. Létezik azonban egyfajta kvalitatív ta- 
2. fejezet: Három megtakarítói típus: egy adaptív-evolúciós megközelítés

nulás is, ami azt jelenti, hogy minőségileg is változhat valaki viselkedése. Nyilván a különbség relatív matematikailag, a kvalitatív tanulás is parametrizálható kvantitatívként. A lényeges megkülönböztetés talán az időtényezô. A kvantitatív tanulás gyorsabb, míg a kvalitatív tanulás lassabb, ritkábban van rá mód. Az elóbbi fajta tanulás sok közgazdasági ABM-et jellemez, az utóbbi viszonylag ritkább. (Arifovic [2000] példa a genetikus algoritmusok használatára a közgazdaságtanban, ami elsôsorban az utóbbi kategóriába tartozik.)

A közgazdaságtanban az ABM-ek egyik viszonylag újabb alkalmazási területe a makroökonómia. (Lásd Deissenberg et al. [2008], Delli Gatti et al. [2011].) Mára kialakult egy bizonyos fajta sztenderdje is ezeknek a modelleknek, némi differenciálódással attól függóen, hogy milyen problémára alkalmazzák ôket. Egy makroökonómiai modell szükségképpen többfajta szereplőt (háztartás, vállalat, bank stb.) tartalmaz, és számos fajta döntést. Az ABM-ek készítôi sokfajta nem-sztenderd viselkedési forma között választhatnak az egyes ágensek viselkedésének leírásakor. Igyekeznek empirikusan alátámasztott döntési szabályokat alkalmazni, de ennek lehetőségei korlátozottak, hiszen a valóban "bizonyított" empirikus viselkedési szabály ritkább, mint a fehér holló, s ezért gyakran plauzibilis, ám ad hoc megoldásokat alkalmaznak.

Ebben az írásban a makroökonómiai modellek egy nagyon fontos aspektusára, a megtakarítási szabályra koncentrálunk, és azt kérdezzük, hogy az adaptív viselkedést feltételező $\mathrm{ABM}$ megközelítés tud-e valamit mondani a makromodellek számára arról, hogy milyen megtakarítási szabályt célszerú feltételezni, illetve azoknak milyen következményei vannak. Tudomásunk szerint az adaptív megközelítést a megtakarítási magatartás szempontjából eddig nem alkalmazták ABM-ekben. A kérdés pedig érdekes és nem-triviális, hiszen mind a hagyományos, mind az újabb modellek feltételezik látszólag "alacsonyabbrendû" viselkedési formák létét, anélkül, hogy ezek hosszú távú fennmaradását magyaráznák.

A következô szakaszban először áttekintjük célkitûzésünk szempontjából a hagyományos megtakarítási irodalmat, majd a kapcsolódó ABM irodalmat. Ezután kvalitatíve azonosítjuk három típusát a megtakarítóknak, amely típusok mind elméletileg, mind empirikusan alátámaszthatónak túnnek. Az 2.5. szakaszban egy 
ABM elemzésével azt a kérdést tesszük fel, hogy vajon milyen körülmények között élhetnek együtt ezek a típusok, és milyen következményekkel jár az aggregált megtakarítói viselkedésre az együttélésük. Mint látni fogjuk az eredmények komplexek, arra utalnak, hogy a szelekciós erő és a társadalmi eredményesség közti kapcsolatok sokkal bonyolultabb kölcsönhatásban vannak, mint ahogy azt talán naívan sokáig értelmezték a közgazdászok. A záró szakaszban a tanulmány konklúziójaként javaslatokat teszünk a megtakarítások modellezésére ABM-ekben.

\subsection{Megtakarítói típusok}

\subsubsection{A fogyasztás-megtakarítás hagyományos elméletei}

A fogyasztási-megtakarítási döntések empirikus modellezőinek régóta szembe kellett néznie az egyének közti heterogenitás problémájával. Létezik egy régi tradíció, amely az egyéneket (háztartásokat) két csoportra osztja: egyrészt vannak, akik a hosszú távon hasznosságot maximalizáló fogyasztó eredetileg Irving Fisher által megfogalmazott elméletének megfelelően cselekszenek (racionális ágensek), és azok, akik - látszólag - rövidlátó módon mindig annyit fogyasztanak, amennyit csak tudnak. A különböző elméletek az utóbbiakat illetően lényegében abban különböznek, hogy minek tudják be ezt a viselkedést: rövidlátásnak, egyszerú irracionalitásnak, vagy likviditási (hitel) korlátoknak. Campbell - Mankiw [1989] az "irracionalitás" felfogást követik, ahol a háztartások egy nem elhanyagolható része rövidlátóan a jövedelmének nagy hányadát elfogyasztja minden időszakban, anélkül, hogy törôdne a jövôvel. Ezen fogyasztók esetében a pillanatnyi jövedelem és fogyasztás között szoros a korreláció, függetlenül attól, hogy a jövedelem változásai permanens vagy idôleges tényezőktôl függ.

Az utóbbi évtizedek viselkedési közgazdaságtani modelljei a rövidlátás és irracionalitás modellezésére törekedtek, és különbözố elméletek alakultak ki ennek magyarázatára. Talán a leginkább elterjedt ezek közül a hiperbolikus diszkontálás modellje, amivel a megtakarítási döntéseket gyakran elemzik az utóbbi idóben, 
2. fejezet: Három megtakarítói típus: egy adaptív-evolúciós megközelítés

de megjelentek, ha nem is terjedtek el ugyanolyan mértékben, olyan elméletek is, amelyek a korlátozott kognitív képességeket hangsúlyozzák, és olyanok is, amelyek az emberi psziché belsố inkonzisztenciájának (kettôs-én elméletek) feltevésén nyugszanak.

Egy modern változat a hiperbolikus diszkontrátákkal és némi naivitással magyarázza a rövidlátó viselkedést (lásd Laibson [1997]). Hiperbolikus és naiv fogyasztók preferenciái olyanok, hogy ma relatíve sokat akarnak fogyasztani, és elfelejtik, hogy egyszer a holnap is ma lesz, amikor ugyanúgy fognak érezni. Ha elôrelátóak lennének, akkor tennének valamit annak érdekében, hogy féken tartsák állandó türelmetlenségüket, például illikvid befektetéseket tartanának, vagy egyszerúen csak egy olyan fogyasztási tervük lenne, ami figyelembe veszi, hogy ma a holnapi énükkel részlegesen konfliktusban vannak. Még újabb változatok is léteznek erre a témára (például Fudenberg-Levine [2006]), amelyek az egyént kétlelkűnek tekintik, aki forró és hûvös állapotban létezhet, amikor a forró állapotban nem tudunk hosszú távú érdekeinknek megfelelően cselekedni. Mindezek az elméletek a racionális és irracionális megtakarítási viselkedés perzisztens együttéléséhez vezetnek, de nem magyarázzák meg, hogy a (kulturális) evolúció miért nem képes kiradírozni egy látszólag alacsony hatékonyságú viselkedési mintát.

A racionális (fogyasztás-simító és előrelátó) viselkedésnek több változata létezik az irodalomban. A korai elméletek nem törődtek a jövedelem nem-diverzifikálható kockázataival, és ezért a fogyasztók kockázatviselő képessége nem játszik különösebb szerepet ezekben a modellekben. Egy általános eredmény, hogy ilyen feltételek mellett a vagyon nem-stacionárius, illetve a fogyasztás véletlen bolyongást követ végtelen időszakra tervezô háztartás esetében. Az ilyen fogyasztók fogyasztási határhajlandósága jóval nagyobb a permanens jövedelem sokkokra, mint az átmeneti sokkokra. Empirikus tanulmányok egy része azt látszik igazolni, hogy a háztartások egy részét valóban valami ilyen magatartás jellemzi (Hall-Mishkin [1982]).

A nem-diverzifikálható munkajövedelem kockázat és a véges élettartam szerepét hangsúlyozó elméletek is születtek, amelyekben fontos szerepe van a kockázatelutasításnak, sốt a prudens preferenciáknak. Az empirikus fogyasztási függvény irodalom egyik legismertebb eredménye a puffer modell, amely egy hagyományos el- 
méletból levezetett nem-parametrikus empirikus fogyasztási függvény. (Lásd SummersCarroll [1991].) Az eredmény úgy foglalható össze, hogy prudens preferenciákkal rendelkezô, viszonylag jelentôs nem diverzifikálható munkajövedelem kockázattal bíró háztartások viselkedését az jellemzi, hogy egy vagyon puffer fenntartására törekszenek, amelyet a vagyon/jövedelem aránnyal lehet jellemezni. (Például a vagyon puffer féléves jövedelemnek feleljen meg.) Ha a puffer túl nagy, akkor többet fogyasztanak a szokásosnál, ha túl kicsi, akkor kevesebbet. Empirikus eredmények igazolni látszanak egy ilyen jellegú reláció létét a gyakorlatban is (lásd Carroll [1996].)

\subsection{Megtakarítási szabályok makro ABM-ekben}

Makroökonómiai ABM-eknek természetesen tartalmazniuk kell valamilyen megtakarítási szabályt is. Mivel ezekben a modellekben általában nincsenek hasznossági függvények a modellezók az empirikus irodalomra hivatkozva igazolják választásukat.

Dosi et al. [2013] például annak a stilizált ténynek az alapján, mi szerint a fogyasztás jól "nyomon követi" a folyó jövedelmet azzal a feltevéssel él, hogy a háztartások minden időszakban igyekeznek a teljes folyó jövedelmüket elfogyasztani, azaz mintha a fogyasztók alapvetően rövidlátók lennének. Egy másik jól ismert stilizált tény a fogyasztási függvény konkávitása, vagyis az a megfigyelés, hogy a megtakarítási határhajlandóság a rendelkezésre álló források növekvô függvénye. Ilyen fogyasztási függvényt specifikál például az irodalom egyik zászlóshajója, a BAM modell (lásd Delli-Gatti et al. [2011]).

Egyre több olyan ágens-alapú modell van, amely a puffer elméletból indul ki. Ennek az elméletnek egy leegyszerúsített (parametrizált és linearizált) változatát több makro ABM is használta. (Például a BAM egy változata, valamint az EURACE (lásd Deissenberg et al [2008].) 
2. fejezet: Három megtakarítói típus: egy adaptív-evolúciós megközelítés

\subsection{A három típus és versenyük}

A fentiek alapján a háztartások három típusa rajzolódik ki, amelyeket az irodalom azonosított, és amelyek "létére" vannak bizonyos bizonyítékok is. Ez a három típus eléggé különbözik egymástól ahhoz, hogy kvalitatíve különbözőnek tekintsük óket, mintegy különbözố mémeknek.

1. Permanens jövedelem típus. Ez a fajta háztartás hosszú távon tervez, igyekszik előrejelezni a jövedelmét, és a fogyasztását simítani. Hajlandó mind megtakarítani, mind pedig hitelt felvenni szükség esetén.

2. Prudens típus. Ez a háztartás prudens módon tartalékol, de amennyiben túlzottan nagyok a tartalékai, nem rest leépíteni azokat. Bár mindig pozitív vagyon elérésre törekszik, véletlenszerúen előfordulhat, hogy adósságba veri magát, ám ezt igyekszik minél hamarabb törleszteni.

3. Rövidlátó típus. Nem törôdik a jövôvel, a fogyasztás rövid távú maximalizálásra törekszik. Ha ehhez hitelt kell felvennie megteszi, de mintegy véletlenszerúen előfordulhat az is, hogy fölöslege van, és vagyont is felhalmozhat.

Ez a három típus nem adódik szigorúan a hasznosságmaximalizáló modellek típusaiból, csak hasonlít hozzájuk. Mivel nem tételezünk fel hasznossági függvényt nem kérdezhetjük azt, hogy szubjektíve megéri-e valamilyen típusúnak lenni, viszont fel fogjuk tenni azt a kérdést, hogy hosszú távon megéri-e. A "fittségi" kritériumunk az idóbeli átlagos fogyasztás, feltesszük, hogy létezik egy olyan adaptációs evolúciós mechanizmus, amely a hosszú távú fogyasztás szempontjából eredményesebb viselkedési mintákat propagálja a társadalomban.

Milyen hátrányai és elônyei lehetnek az egyes típusoknak? A rövidlátó típus várhatóan alacsony nettó tókével rendelkezik hosszú távon, s emiatt fogyasztása sem lehet nagyon magas. Első nekifutásra ennek a típusnak a hosszú távú fennmaradása erôsen kétségesnek tûnik, ha az adaptáció kényszere nagy. A permanens jövedelem fogyasztó józanul a vagyona szinten tartására növekszik, azaz egy stabil fogyasztást igyekszik biztosítani magának. Véthet azonban hibákat a jövő előrejelzésénél, ami 
költséges lehet, továbbá mivel hitelt ô is szívesen vesz fel, összességében nem biztos, hogy tôkejövedelme nagyon nagy lesz. A prudens háztartás biztonságra törekszik, akkor is módja lesz fogyasztani eladósodás nélkül is, ha a munkajövedelme alacsony, de lehet, hogy túlzottan takarékos, keveset fogyaszt ahhoz képest, hogy mekkora vagyont tart "fölöslegesen".

Kérdés az is, hogy milyen "társadalmi" hatást fejtenek ki az egyes típusok. Elsô látásra egy prudens fogyasztó társadalmi (másokra való) hatása pozitív, míg egy rövidlátó hatása negatív, amennyiben az elsô növeli, a második pedig csökkenti a társadalmi tókét, és ezáltal a munka termelékenységét is. Nem triviális, hogy lehetséges-e és mi a hatása az együttélésüknek. Mint láttuk az ABM-ek csak egyik vagy másik típus létét tételezik fel, de ez nagyon valószínútlen. Szinte minden vizsgálat azt bizonyítja, hogy léteznek prudens háztartások, de hogy csak ilyenek léteznének, azt cáfolni látszik a háztartások néha jelentôs eladósodása. Nehezen hihető az is, hogy csak rövidlátó fogyasztók vannak, hiszen láthatólag vannak pozitív megtakarítók minden társadalomban hosszú távon is.

A három típus konkrét modellezésénél számos kérdést kell feltennünk. Például a rövidlátó fogyasztónál valahonnan származtatni kell a fogyasztási célt, a prudens ágensnél a kívánt vagyonpuffer nagyságát, a permanens jövedelem típusnál pedig azt, hogy hogyan határozza meg permanens jövedelmét. A modell részletes leírásánál adunk választ ezekre a kérdésekre. Mint látható lesz "bizonyos" altípusok létét, és azok közti versenyt, az egyes típusokon "belüli" kiválasztódási mechanizmust fogunk feltételezni a típusok közötti verseny mellett.

\subsection{Egy ABM és szimulációs eredményei}

\subsubsection{A modell}

A modell technológiai vázát az úgynevezett Bewley-típusú modellektől (Bewley [1980]) vettük át. A Bewley-típusú modelleket fóként abból a célból tanulmányozták, hogy inkomplett piaci feltételek mellett mit tudunk mondani makromodellek 
egyensúlyáról. A modellben egyéni technológiai bizonytalanság van, aggregált technológiai bizonytalanság nem létezik. Kétfajta megtakarítási lehetôség van ebben a konkrét modellben: fizikai tôke és magánhitelek. A jelen modellt megkülönbözteti a hagyományos Bewley-modellektôl az aktívapiacok kezelése, és elsôsorban, a fogyasztói viselkedés modellezése.

\section{A termelési-elosztási oldal}

A termelési és elsődleges jövedelem elosztási része a modellnek Aiyagari [1994] cikkét követi. Létezik $N$ ex ante azonos háztartás, mely mindegyike végtelen élettartamú. Minden háztartás (homogén) munkakínálatát azonos kétállapotú Markovlánccal jellemezzük, amelynek az átmenet mátrixa:

\begin{tabular}{|c|cc|}
\hline & $L_{1}$ & $L_{2}$ \\
\hline$L_{1}$ & $p$ & $1-p$ \\
$L_{2}$ & $1-q$ & $q$ \\
\hline
\end{tabular}

ahol $L_{1}<L_{2}, p<q$. Tehát, ha a háztartások száma nagy, akkor a munkakínálati aggregált bizonytalanság kicsi, jóllehet az egyéni kínálati bizonytalanság lehet jelentôs. A munkapiacok mindig egyensúlyban vannak, és a munka díjazása határtermékén történik. A gazdaság aggregált termelési függvénye Cobb-Douglas, argumentumai az aggregált munka és az aggregált tôke, a munka részesedése $\alpha$.

$$
L_{t}=\sum_{k} L_{t, k}, \quad K_{t}=\sum_{k} K_{t, k} \quad \text { és } \quad Y_{t}=K_{t}^{1-\alpha} L_{t}^{\alpha},
$$

ahol $L_{t}$ az aggregált munka, $L_{t, k}$ a $k$ háztartás munkakínálata, $K_{t}$ az aggregált fizikai tóke, $K_{t, k}$ a $k$ háztartás fizikai tókeállománya, $Y_{t}$ az aggregált output és $0<\alpha<1$. Az egységbér $\left(w_{t}\right)$, és az egységnyi tôkeszolgáltatások járadéka $\left(r_{t}^{K}\right)$ implicite kifejezhetô, mint

$$
w_{t} L_{t}=\alpha Y_{t} \quad \text { and } \quad r_{t}^{K} K_{t}=(1-\alpha) Y_{t}
$$


A szimulációk elsô időszakában minden ágens egy véletlen nagyságú tôkével rendelkezik. A tôke idôszakonként $\delta$ százalékban amortizálódik.

Ez a modell ugyan egyéni munkakínálat bizonytalanságot tartalmaz, de az aggregált munkakínálat nagyszámú ágens esetén közelítôleg konstans, és ez a konstans munkakínálat $(L)$ egyértelmúen meghatározható a Markov-lánc paramétereiból, valamint az ágensek számából. Ekkor értelmezhetô ebben a Cobb-Douglas termelési függvénnyel rendelkezô gazdaságban a (közelítő) aranykori megtakarítási ráta, és az ennek megfelelő aranykori tôkeállomány és fogyasztás. Tudjuk, hogy Cobb-Douglas esetben az aranykori megtakarítási ráta $1-\alpha$, és

$$
\begin{aligned}
K^{*} & =\left(\frac{1-\alpha}{\delta}\right)^{\frac{1}{\alpha}} L \\
C^{*} & =\alpha K^{1-\alpha} L^{\alpha}
\end{aligned}
$$

az aranykori tókeállomány és fogyasztás.

\section{A fogyasztási oldal}

Minden időszak kezdetén az idioszinkratikus munkakínálati sokkok realizálódnak, majd a termelés és az elsődleges jövedelem elosztása történik meg. Az egyes háztartások teljes rendelkezésre álló erőforrásai:

$$
A_{t, k}=\left(1-\delta+r_{t}^{K}\right) K_{t, k}+\left(1+r_{t}\right) B_{t, k}+w_{t} L_{t, k}-\left(1+r_{t}\right) D_{t, k}
$$

ahol $A_{t, k}$ a $k$ háztartás erőforrásai, $r_{t}$ a kamatláb, amit a hiteleken érvényesítenek, $B_{t, k} \geq 0$ a háztartás más háztartásoknak nyújtott ma lejáró hitelei, és $D_{t, k} \geq 0$ a háztartás általi tartozások. (A hitelezésról lásd lejjebb.) Az $A_{t, k}$ tehát tartalmazza a nettó vagyont $\left(K_{t, k}+B_{t, k}-D_{t, k}\right)$, a jelenlegi jövedelmet $\left(r_{t}^{K} K_{t, k}+r_{t} B_{t, k}+w_{t} L_{t, k}\right)$, de levonjuk az amortizációt és a kamatkiadásokat $\left(\delta K_{t, k}+r_{t} D_{t, k}\right)$. 
2. fejezet: Három megtakarítói típus: egy adaptív-evolúciós megközelítés

A háztartások egy Erdôs-Rényi-féle véletlen gráf csomópontjain helyezkednek el (Erdős-Rényi [1959]), melyben minden lehetséges ágenspárt $\rho_{1}$ valószínúséggel kötöttünk össze, $d g$ pedig a reguláris kezdeti gráf fokszáma. Az ágensek között a gráfot minden idôszakban adott $\rho_{2}$ valószínúséggel újrageneráljuk. Egy adott időszakban minden fogyasztó három típus valamelyikéhez tartozik: $T_{t}(k)=a$, $T_{t}(k)=b$ vagy $T_{t}(k)=c$, ahol $a$ a permanens jövedelem típust, $b$ a prudens típust, $c$ pedig a rövidlátó típust jelöli.Az első időszakban az ágensek egyenlő valószínűséggel kerülnek a három típus valamelyikébe. Mindhárom típusnak megvan a saját fogyasztástervezési szabálya, amely paraméterei azonban függnek a háztartás aktuális állapotától.

A permanens jövedelem típus tervei A permanens jövedelem típushoz tartozók megpróbálják eloorejelezni teljes életpálya vagyonukat, és azt tervezik, hogy konstans (nem-negatív) fogyasztást realizálnak ennek alapján.

$$
C_{t, k}^{P}=\chi_{t, k} \max \left(0, \frac{\widetilde{E}_{t, k}(r)}{1+\widetilde{E}_{t, k}(r)} A_{t, k}+\frac{1}{1+\widetilde{E}_{t, k}(r)} \widetilde{E}_{t, k}\left(L W_{t, k}\right)\right),
$$

ahol $C_{t, k}^{P}$ a $k$ háztartás tervezett fogyasztása a $t$ időszakban, ha $T_{t}(k)=a, \chi_{t, k}$ a háztartás optimizmusát jellemzô paraméter, és $\widetilde{E}_{t, k}\left(L W_{k}\right)$ és $\widetilde{E}_{t, k}(r)$ az átlagos munkajövedelem és kamatláb várt értékei. $\chi_{1, k}$ egy $[\bar{\chi}, \underline{\chi}]$ intervallumon egyenletes eloszlású valószínúségi változó realizációja, késôbbi alakulásának mikéntjét az Adaptáció-szelekció-mutáció részben ismertetjük. A várakozások súlyozott átlagai a változók realizált értékeinek exponenciálisan csökkenô súlyokkal. Rekurzívan a következóképpen definiálhatók:

$$
\begin{aligned}
\widetilde{E}_{t, k}\left(L W_{k}\right) & =\theta \widetilde{E}_{t-1, k}\left(L W_{k}\right)+(1-\theta) w_{t} L_{t, k} \\
\widetilde{E}_{t, k}\left(r_{k}\right) & =\theta \widetilde{E}_{t-1, k}\left(r_{k}\right)+(1-\theta) r_{t} .
\end{aligned}
$$

Az elsố szimulációs periódusban:

$$
\begin{aligned}
\widetilde{E}_{1, k}\left(L W_{k}\right) & =w_{1} L_{1, k} \\
\widetilde{E}_{1, k}\left(r_{k}\right) & =r_{1} .
\end{aligned}
$$


A háztartások tehát múltbeli tapasztalataik alapján a történelmi átlagokat vetítik elôre, de úgy hogy minél távolabb megyünk vissza a múltba, a megfigyelések súlya egyre kisebb lesz. Nemstacionárius körülmények között ez a súlyozás intuitíve ésszerú, mivel ilyenkor a távoli múlt információi egyre lényegtelenebbek. Viszont, ha mégis stacionárius lenne a világ, akkor hosszú távon a súlyozás nem csökkentené lényegesen az előrejelzés hatékonyságát.

A prudens típus fogyasztási tervei Minden fogyasztó rendelkezik egy számára kívánatos vagyon/jövedelem aránnyal:

$$
h_{t, k}=A_{t+1, k} / \operatorname{Inc} c_{t, k}
$$

ahol a $k$ háztartás jövedelme a t-edik időszakban

$$
\operatorname{Inc}_{t, k}=r_{t}^{K} K_{t, k}+w_{t} L_{t, k}+r_{t} B_{t, k}-r_{t} D_{t, k},
$$

$h_{1, k}$ egy $\bar{h}$ várhatóértékú, exponenciális eloszlású valószínúségi változó realizációja. Értéke késôbb módosulhat: ennek mikéntjét az Adaptáció-szelekció-mutáció részben ismertetjük. Ha az aktuális vagyon/jövedelem arány $\left(A_{t, k} / \operatorname{Inc}_{t-1, k}\right)$ magasabb a kívánt aránynál, akkor többet fogyasztanak a szokásosnál, ha kisebb, akkor kevesebbet. Delli Gatti et al. [2011] leírását követve ekkor a prudens fogyasztó fogyasztási szabálya a következóképpen alakul:

$$
C_{t, k}^{P}=\max \left\{0, \frac{\operatorname{Inc_{t,k}}\left[1+\left(A_{t, k} / I n c_{t-1, k}-h_{t, k}-g_{t, k}\right)\right]}{1+g_{t, k}}\right\},
$$

ahol $g_{t, k}$ az ágens jövedelmének növekedési üteme a $t$-edik és a $t$ - 1-edik idôszak között.

A rövidlátó típus fogyasztási tervei A rövidlátó háztartások kizárólag a fogyasztásra koncentrálnak. A szomszédos ágensek közül a legmagasabb fogyasztással rendelkezôt tekintik referenciának, és optimizmusuk fokának megfelelően az ô fogyasztását szeretnék elérni, azaz ha $T_{t}(k)=c$, akkor

$$
C_{t, k}^{P}=\chi_{t, k} \max \left(0, C_{t, k}^{\max }\right)
$$


ahol $C_{t, k}^{\max }$ a szomszédos (azonos élen elhelyezkedô) ágenesek fogyasztása közül a legmagasabb a $t$-edik idôszakban, $\chi_{t, k}$ ismét a háztartás optimizmusát jellemzô paraméter. $\chi_{1, k}$ egy $[\bar{\chi}, \underline{\chi}]$ intervallumon egyenletes eloszlású valószínúségi változó realizációja, melynek késóbbi alakulásáról az "Adaptáció-szelekció-mutáció" alfejezetben írunk.

\section{Fogyasztás}

$\mathrm{Ha}$

$$
C_{t, k}^{P} \leq A_{t, k}
$$

akkor a háztartás pillanatnyi fogyasztási tervét képes realizálni, tehát

$$
C_{t, k}=C_{t, k}^{P}
$$

és a háztartás megtakarított erőforrásállománya:

$$
W_{t+1, k}=A_{t, k}-C_{t, k} \geq 0
$$

Egyébként:

$$
C_{t, k}=\min \left[C_{t, k}^{P}, \max \left(0, A_{t, k}+\frac{1}{1+r_{t+1}} \bar{D}_{t}\right)\right]
$$

ahol $\bar{D}_{t}$ egy általános hitelkorlát, és $r_{t+1}$ a kamatláb a $t+1$-edik periódusban lejáró hiteleken. A hitelkorlát értékét a "legrosszabb esetben" realizálható bérjövedelem örökjáradékosított értéke határozza meg, ahol a kamatláb értékét perturbáltuk, hogy minden esetben pozitív maradjon.

A $k$ háztartás hitelkereslete:

$$
D_{t+1, k}=\max \left[0, \min \left(\frac{1}{1+r_{t+1}} \bar{D}, C_{t, k}^{P}-A_{t, k}\right)\right]
$$




\section{A hitelpiac}

A kamatlábat meghatározó összefüggés:

$$
r_{t+1}=\omega\left(\sum_{k} D_{t-1, k} / Y_{t-1}\right)^{2}+\max \left(0, r_{t}^{K}-\delta\right),
$$

vagyis a hitelpiacon a kamatláb mindig legalább akkora, mint a tóke realizált nettó hozama. Ez egy naív centralizált hitelpiacot tételez fel, ahol az előzố idôszaki hozamot mintegy referenciának tekintik, de a hitelezók felhasználva azt, hogy a hitelfelvevőknek "szükségük" van rájuk, erre "rátesznek" egy kis marzsot. Továbbá a kamatláb értékét úgy perturbáljuk, hogy semmiképpen ne legyen negatív.

Ha a megvalósíthatósági kritérium

$$
\sum_{k} W_{t+1, k} \geq \sum_{k} D_{t+1, k}
$$

teljesül, akkor a megtakarítások kínálata konzisztens a hitelkereslettel. Ebben az esetben

$$
\begin{aligned}
& B_{t+1, k}=W_{t+1, k} \frac{\sum_{k} D_{t+1, k}}{\sum_{k} W_{t+1, k}}, \\
& K_{t+1, k}=W_{t+1, k}-B_{t+1, k},
\end{aligned}
$$

vagyis a hitelek és a fizikai tőke portfóliósúlyai azonosak minden háztartásnál, ha a háztartás nettó megtakarításainak egyenlege pozitív. Amikor a megvalósíthatósági feltétel nem teljesül, a hitelezók leírják az adósok adósságát ( $B_{t+1, k}=D_{t+1, k}=0 \forall k$-ra), de a hitelezés a következô idôszaktól újra beindul. 
2. fejezet: Három megtakarítói típus: egy adaptív-evolúciós megközelítés

\section{Adaptáció-szelekció-mutáció}

A modellben nincs szubjektív hasznosság, de az akkumulált hasznosság mintegy életrevalósági (fitness) kritériumként funkcionál (Brock-Holmes [1997]). Az ágensek sikerességét akkumulált fogyasztásukban mérjük az alábbi módon:

$$
U_{t, k}=\lambda U_{t-1, k}+(1-\lambda) C_{t, k}, 0<\lambda<1
$$

Minden időszakban egy kis $\left(\rho_{3}\right)$ valószínúséggel egy ágens képes típust váltani. Ilyenkor az ágens beazonosítja mindhárom csoportban (permanens jövedelem típus, prudens típus, rövidlátó típus) a legnagyobb $U_{t-1}$ értékkel rendelkezőket. Legyenek ezek az értékek $U_{t-1, k(a)}^{*}, U_{t-1, k(b)}^{*}$ és $U_{t-1, k(c)}^{*}$. Ekkor a $k$ ágens típusa $\tau(\tau=a, b$ vagy c) lesz

$$
\operatorname{Pr}\left(T_{t}(k)=\tau\right)=\frac{\exp \left(\frac{U_{t-1, k(\tau)}^{*}}{\Upsilon}\right)}{\exp \left(\frac{U_{t-1, k(a)}^{*}}{\Upsilon}\right)+\exp \left(\frac{U_{t-1, k(b)}^{*}}{\Upsilon}\right)+\exp \left(\frac{U_{t-1, k(c)}^{*}}{\Upsilon}\right)}
$$

valószínûséggel, ahol egy nagy $\Upsilon>0$ azt jelenti, hogy a típusváltásnál a siker majdnem irreleváns, míg ha $\Upsilon$ 0-hoz közeli, akkor nagy a valószínúsége, hogy a sikeresebb típus gyôz. Bármelyik eset is realizálódik a $k$ háztartás örökli a "gyôztes" sikermutatóját, habár ez azonnal erodálódik, amennyiben $\lambda<1$. A sikermutatón felül az ágensek öröklik a "gyôztes" optimizmusának fokát $\left(\chi_{t, k}\right)$, ha $T_{t}(k)=a$ vagy $T_{t}(k)=c, T_{t}(k)=b$ esetén pedig annak kívánt vagyon/jövedelem arányát $\left(h_{t, k}\right)$.

Egy kis valószínúséggel $\left(\rho_{4}\right.$, illetve $\left.\rho_{5}\right)$ az ágensek mutálódnak: optimizmusuk foka és a kívánt vagyon/jövedelem arányuk véletlenszerúen megváltozhat. Az optimizmus fokának új értéke a régi érték és egy egyenletes eloszlású valószínûségi változó konvex kombinációja:

$$
\chi_{t, k}^{n}=\phi \chi_{t, k}^{o}+(1-\phi) \varsigma_{t, k},
$$

ahol $\chi_{t, k}^{n}$ az optimizmus új, $\chi_{t, k}^{o}$ a régi értéke, $\varsigma_{t, k}$ egy $[\bar{\chi}, \underline{\chi}]$ intervallumon egyenletes eloszlású valószínúségi változó realizációja, $0<\phi<1$ pedig a régi érték súlya a 
kombinációban. A kívánt vagyon/jövedelem arány esetén pedig

$$
\log h_{t, k}^{n}=\log h_{t, k}^{o}+\nu_{t . k}
$$

ahol $h_{t, k}^{n}$ az új arány, $h_{t, k}^{o}$ a régi, $\nu_{t, k}$ pedig egy normális eloszlású valószínúségi változó $\left(\nu_{t, k} \sim N(\mu, \sigma)\right)$ realizációja.

\subsubsection{A szimulációk eredményei}

Paraméterek A "hőmérséklet" $(\Upsilon)$ kivételével a közölt szimulációkban a modell leírásban szereplő paraméterek értéke ugyanaz. Ezeket az 2.1. táblázatban mutatjuk be. 
2. fejezet: Három megtakarítói típus: egy adaptív-evolúciós megközelítés

2.1. táblázat. A rögzített paraméterek értéke

\begin{tabular}{|l|l|c|}
\hline \hline Paraméter & Jelentése & Érték \\
\hline$N$ & ágensek száma & 200 \\
$p$ & alacsony munkakínálati állapot megmaradásának valószínúsége & 0,4 \\
$q$ & magas munkakínálati állapot megmaradásának valószínúsége & 0,95 \\
$L_{1}$ & alacsony munkakínálat & 0,1 \\
$L_{2}$ & magas munkakínálat & 1 \\
$\alpha$ & munka részesedése a jövedelemból & 0,67 \\
$\delta$ & amortizációs ráta & 0,005 \\
$\rho_{1}$ & ágensek közti kapcsolat valószínúsége & 0,05 \\
$\rho_{2}$ & kapcsolatváltás valószínúsége & 0,01 \\
$\rho_{3}$ & típusváltás lehetóségének valószínúsége & 0,001 \\
$\rho_{4}$ & az optimizmus foka mutációjának valószínúsége & 0,01 \\
$\rho_{5}$ & a kívánt vagyonpuffer mutációjának valószínúsége & 0,01 \\
$d g$ & reguláris kezdeti gráf fokszáma & 6 \\
$\bar{\chi}$ & az optimizmus fokának felsó korlátja & 1,1 \\
$\chi$ & az optimizmus fokának alsó korlátja & 0,9 \\
$\theta$ & memória paraméter & 0,8 \\
$\bar{h}$ & kívánt vagyonpuffer & 120 \\
$\omega$ & "marzs" paraméter a hitelpiacon & 0,002 \\
$\lambda$ & fitnessz memória paraméter & 0,9 \\
$\phi$ & optimizmus foka memória paraméter & 0,95 \\
$\mu$ & kívánt vagyonpuffer mutációs paraméter (várható érték) & 0 \\
$\sigma$ & kívánt vagyonpuffer mutációs paraméter (variancia) \\
\hline \hline
\end{tabular}

Az adott paraméterek mellett az aranykori aggregált tókemennyiség 96745, 5, az aggregált aranykori fogyasztás pedig 982,1135. A fogyasztási és tókeadatokat a táblázatokban és az ábrákon is a megfelelő aranykori egységekben (szorozva 100zal) fejezzük ki. Tehát például $K=120$ jelentése: az aranykori tóke 120\%-a. Mint látni fogjuk, a szimulációk eredményeként adódó idôsorok úgy túnik, függnek a tôke kezdőértékétôl. Az alábbiakban az aranykori aggregált tôkével számolunk, mint kezdő tókével. 


\section{A szimulációk értelmezése}

A makroökonometriában használt módszerek (például a vektor-autoregresszív modellek, a VAR-ok) többnyire felteszik az empirikus makroökonómiai idősorok ergodicitását. Hagyományos makroökonómiai elméleti modellekból generált idôsorok általában stacionáriusak, sốt ergodikusak. Ágens-alapú makromodellek esetében az analitikus eredmények hiánya miatt ezek a tulajdonságok csak "tapasztalatilag" állapíthatóak meg, vagyis a szimulált idôsorok formális vagy informális tesztelésével. Intutívan egy modell stacionárius, ha egy szimulált idôsor minden részidősora hosszú távon "sztochasztikusan azonos". Elméletileg léteznek olyan stacionárius idôsorok is, amelyek nem-ergodikusak, vagyis amelyek esetében ugyan egy adott szimuláció különböző "részei" hasonlóak, de különbözô szimulációk eredményei lényeges eltéréseket mutatnak. (Például minden szimulációban az átlag konvergál, de ezek az átlagok nem ugyanahhoz a számhoz konvergálnak.) A stacionaritás és ergodicitás hangsúlyozottan aszimptotikus tulajdonságok, véges mintából nem állapítható meg 1 valószínúséggel meglétük vagy hiányuk, de léteznek tesztek ezek "eldöntésére". Az ágens-alapú modellek nagy dimenziójúak a heterogenitás miatt, és egy ilyen nagy dimenziós modell tesztjei nem is kivitelezhetóek teljes részletességgel. Ezért általában bizonyos aggregált változók hosszú távú viselkedését szokás vizsgálni.

A mi esetünkben a kézenfekvő aggregált állapotváltozó az összes tőke mennyisége. Ennek viselkedése alapján próbálunk a modell hosszú távú viselkedésérôl állításokat tenni. Itt most csak az elsô momentumra, azaz a várható értékre fogunk koncentrálni. Ha az ergodicitás biztosított, akkor elegendő lenne egyetlen "nagyon hosszú" szimulációt lefuttatnunk egy paraméter együttesre, és az abból számított átlagok konzisztens becslést adnának az aggregált stacionárius eloszlásról. Ha az ergodicitás nem teljesül, de a stacionaritás igen, akkor az egyes hosszú futásokból elvben csak "lokális" információt kaphatunk, minden szimuláció (amelynek egyébként ugyanazok a paraméterei) átlagai, bár értelmezhetőek várható értékként, eltérőek lehetnek, és így nem azonosíthatók az "egész" folyamat várható értékével. Ha az ergodicitás tekintetében nem vagyunk biztosak, megtehetjük, hogy egy adott paraméter együtteshez sok hosszú (de nem "nagyon hosszú") szimulációt futtatunk, 
2. fejezet: Három megtakarítói típus: egy adaptív-evolúciós megközelítés

és ezek átlagaiból képzett eloszlást vizsgáljuk. A hosszút esetünkben 5000 periódusként definiáljuk, amit több száz évnek feleltethetünk meg valós idôben, míg a nagyon hosszút 50000 periódusként, amit tehát több ezer évnek. Láthatóan ezek az idôtávok meghaladják azt, ami közgazdasági szempontból releváns, ám nem biztos, hogy az elméleti aszimptoticitás szempontjából is elegendően hosszúnak tekinthetôk-e. Mindenesetre több módszert alkalmazunk vizsgálatukra: formális nem-paraméteres stacionaritás és ergodocitás teszteket, paraméteres stacionaritási teszteket, egyes szimulált idősorok vizuális inspekcióját és összehasonlítását, egyszerú átlagok számítását és az eloszlásaik összehasonlítását.

Nem-parametrikus stacionaritási tesztek Az irodalom alapján több nemparametrikus teszt is használható a stacionaritás vizsgálatára (lásd Gibbons [1985]). Mi egy olyan módszert választottunk, melyet többször alkalmaztak ágens-alapú modellekre, és amely a Wald-Wolfowitz teszt (Wald, Wolfowitz [1940]) kiterjesztése (Grazzini [2012]).

A Wald-Wolfowitz teszt ('Futam teszt") azt vizsgálja, hogy két minta azonos eloszlásból származik-e. A kiterjesztése azt teszteli, hogy egy függvény jól illeszkedik-e a megfigyelések egy halmazához: jó illeszkedés esetén a megfigyeléseknek véletlenszerúen kell szóródnia a függvény fölött és alatt, függetlenül a hibák eloszlásától. Adott becsült függvény mellett 1 szimbólumot rendelünk a függvény fölötti, 0 szimbólumot a függvény alatti megfigyelésekhez. Futamnak az azonos szimbólumok sorozatát tekintjük, melyet az ellentétes szimbólum előz meg és követ. A szimbólumok sorozata nem véletlenszerú, ha a futamok száma túl nagy vagy túl alacsony. Ebben az esetben a null hipotézist, mely szerint a megfigyelések véletlenszerúen szóródnak az adott függvény körül, elutasítjuk (Gibbons [1985]).

A stacionaritás teszteléséhez a modellt 50500 idôszakra szimuláltuk, és az aggregált tőke idősorát 100 egyenlő szakaszra bontottuk az első 500 időszak elhagyása után. Kiszámoltuk mindegyik szakasz átlagát, és megvizsgáltuk, hogy a részminták átlagai a teljes idôsor átlagánál (a függvény, melynek illeszkedését teszteljük) nagyobb (1 szimbólum) vagy alacsonyabb (0 szimbólum). A szimbólumokra a "Futam tesztet" kétoldali alternatív hipotézissel alkalmaztuk (lásd Grazzini [2012]). 
Amennyiben a részminták átlagai véletlenszerúen szóródnak a teljes átlag körül, a stacionaritás null hipotézisét az elsố momentum esetén nem tudjuk elutasítani.

A tesztet $\Upsilon=0,001, \Upsilon=10$ és $\Upsilon=1000$ értékek mellett végeztük el, és az minden sziginifikancia-szinten a stacionaritás null hipotézisét visszautasította. Nem-parametrikus tesztek alapján tehát az idôsorok nem-stacionárusnak tûnnek.

Parametrikus stacionaritási tesztek A stacionaritás vizsgálatára hagyományosan alkalmaznak parametrikus teszteket is, melyek közül az egyik leggyakrabban használtat, a kibővített Dickey-Fuller tesztet (Dickey, Fuller [1979]) mi is elvégeztük a középső 10000 időszak adatain, $\Upsilon=0,001, \Upsilon=10$ és $\Upsilon=1000$ esetben 2.2 . táblázat). A teszt az idősor általános autoregresszív reprezentációján vizsgálja az egységgyök jelenlétét. A Wald-Wolfowitz teszttel szemben a null hipotézise az idősor nem-stacionaritását jelenti. A nem-parametrikus tesztekkel ellentétben azonban az eredmények alapján az egységgyök folyamatot (a nem-stacionaritást) $\Upsilon=0,001$ mellett minden szignifikancia-szinten elutasíthatjuk, $\Upsilon=10$ és $\Upsilon=1000$ mellett azonban csak 7,27 illetve 15,59 százalékos szignifikancia-szinten tehetjük meg ugyanezt.

2.2. táblázat. A kibővített Dickey-Fuller tesztek eredményei $\Upsilon=0,001, \Upsilon=10$ és $\Upsilon=1000$ esetben

\begin{tabular}{|c|ccc|}
\hline \hline & \multicolumn{3}{|c}{$\Upsilon$} \\
\hline & 0,001 & 10 & 1000 \\
\hline MacKinnon p-érték & 0.0000 & 0.0727 & 0.1559 \\
\hline \hline
\end{tabular}

Ergodicitási tesztek Az ergodicitás teszteléséhez ismét a "Futam tesztet" alkalmaztuk, de ezúttal az eredeti, Wald és Wolfowitz [1940] által javasolt formában. A teszt elsố lépései a stacionaritás tesztjéhez hasonlóak: újra 50500 idôszakra szimuláljuk a modellt, az aggregált tőke hosszú idősorát 100 egyenlő szakaszra osztjuk az elsô 500 időszak elhagyásával, és minden szakasznak kiszámoljuk az átlagát. A teszt elsô mintáját $\left(x_{t}\right)$ a 100 részminta átlagából alakítjuk ki. Második lépésként 
2. fejezet: Három megtakarítói típus: egy adaptív-evolúciós megközelítés

100 darab 1000 időszakos idősort generáltunk a modell segítségével (az exogén sztochasztikus változók különböző realizációira), és mindegyikre kiszámoltuk az aggregált tőke átlagát az utolsó 500 időszakra. Az ergodicitás tesztjének második mintáját a 100 mintaátlag képezi $\left(y_{t}\right)$. Ezt követôen egyesítettük a két mintát $\left(x_{t}\right.$ és $y_{t}$ ), és egy olyan $Z$ halmazt álltottunk elő belólük, amely $x_{t}$ és $y_{t}$ elemeit növekvô sorrendbe rendezi. Végül egy $V$ sorozatot képeztünk a következóképpen: $v_{i}=0$, ha $z_{i} \epsilon x_{t}$ és $v_{i}=1$, ha $z_{i} \in y_{t}$. A sorozatra alkalmaztuk a "Futam tesztet" egyoldali alternatív hipotézissel, ahol a null hipotézis szerint $x_{t}$ és $y_{t}$ átlagok azonosak (lásd Grazini [2012]) és az adatgeneráló folyamat ergodikus.

Az ergodicitást null hipotézisét mindegyik $\Upsilon$ értékre, minden szignifikanciaszinten elutasítjuk, az eredmények tehát itt egyértelmúena nem-ergodicitás irányába mutatnak.

Informális tesztek A nem-stacionaritás (nem-ergodicitás) jelentése lényegében az, hogy a modell pályája hosszú távon sem független a kezdeti feltételektôl. Ezt informálisan tesztelhetjük úgy is, hogy különböző aggregált kezdő tôkékhez több szimulációt számolunk, és az egyes szimulációk átlagainak eloszlását vizsgáljuk meg. Mivel 20 szimulációról van szó paraméter kombinációnként az eloszlásnak két tulajdonságát tekintjük csak, az átlagot és a terjedelmet. A 2.3. táblázatból látszik, hogy különbözô hômérsékletek mellett az egyes szimulációk átlagai jól megkülönböztethetők, majdnem diszjunkt intervallumokban foglalnak helyett. (Alacsony és közepes hőmérsékleteknél az intervallumok elég "kicsik").

2.3. táblázat. Az aggregált tókeállomány szimulációnkénti átlagainak átlaga, minimuma és maximuma a "hőmérséklet" ( $\Upsilon$ különböző értékei mellett, az aranykori tôkeállomány százalékában

\begin{tabular}{|l|ccc|}
\hline \hline$\Upsilon$ & átl. & min. & max. \\
\hline 0,001 & 130,51 & 127,10 & 133,76 \\
10 & 115,45 & 105,80 & 124,89 \\
1000 & 100,15 & 79,93 & 113,21 \\
\hline \hline
\end{tabular}


Végül tekintsük a vizuális inspekciót, mint informális tesztet.

2.1. ábra. Az aggregált tókeállomány alakulása $\Upsilon=0,001$ mellett

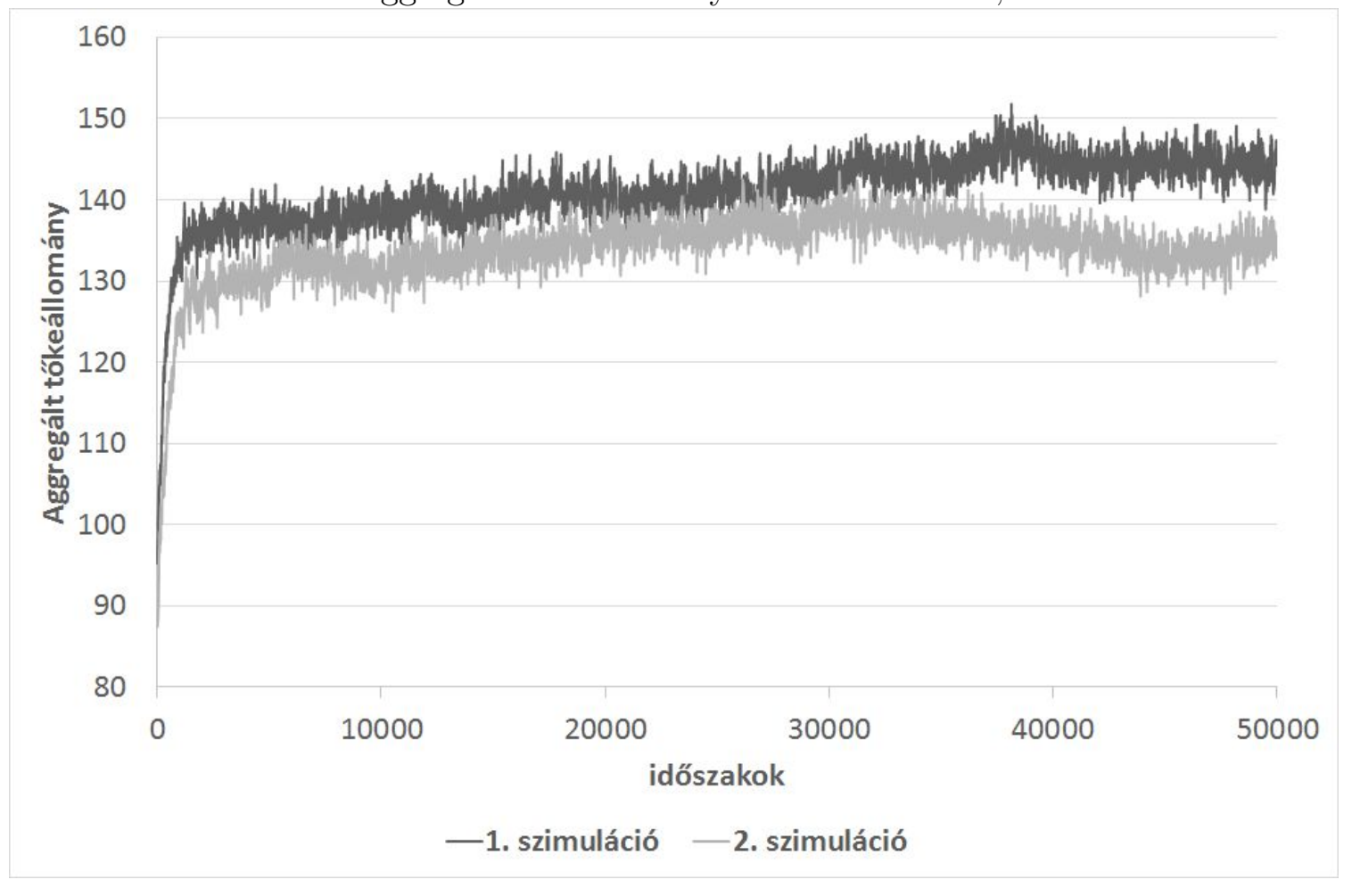


2. fejezet: Három megtakarítói típus: egy adaptív-evolúciós megközelítés

2.2. ábra. Az aggregált tőkeállomány alakulása $\Upsilon=10$ mellett

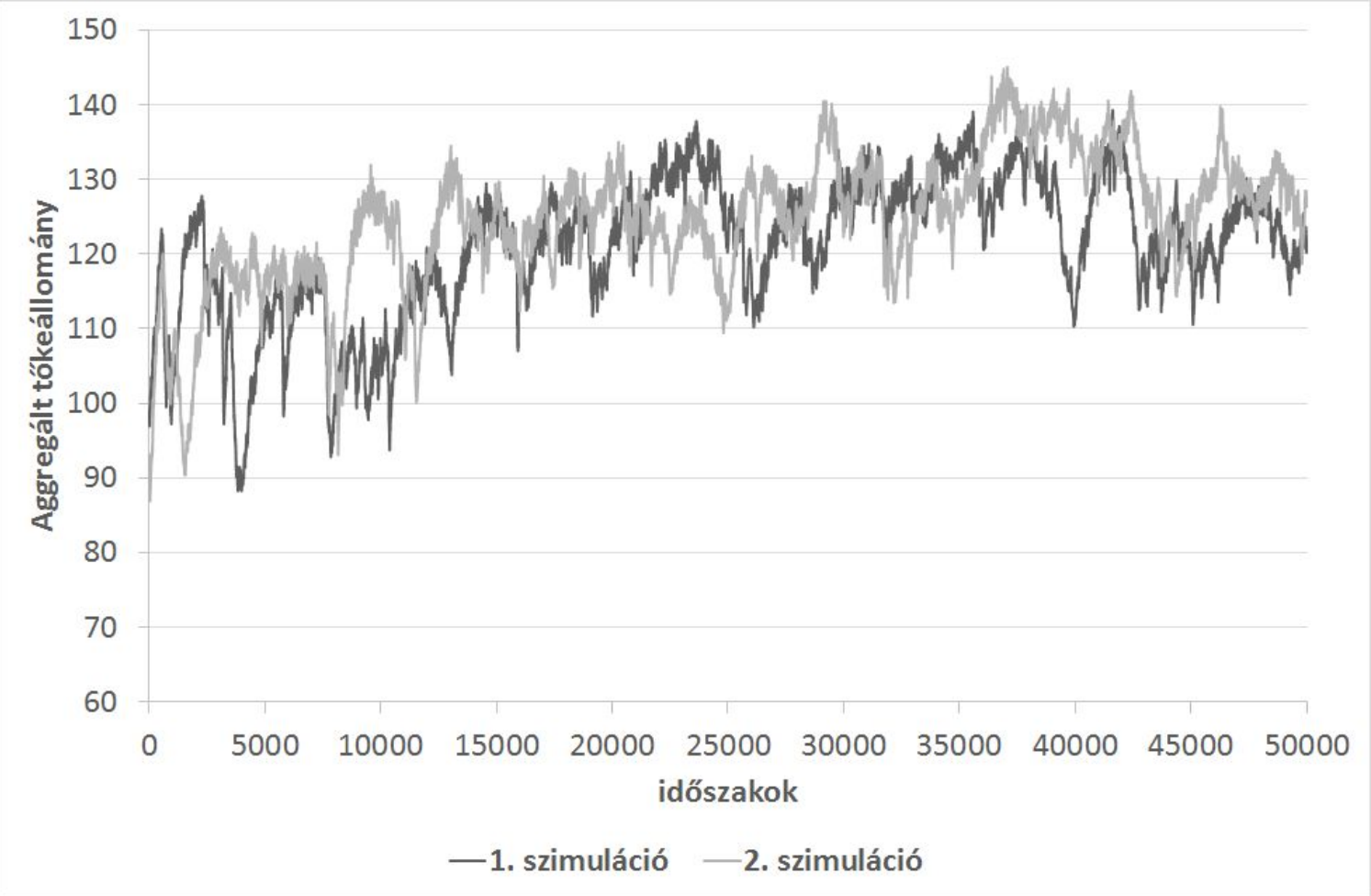


2.3. ábra. Az aggregált tókeállomány alakulása $\Upsilon=1000$ mellett

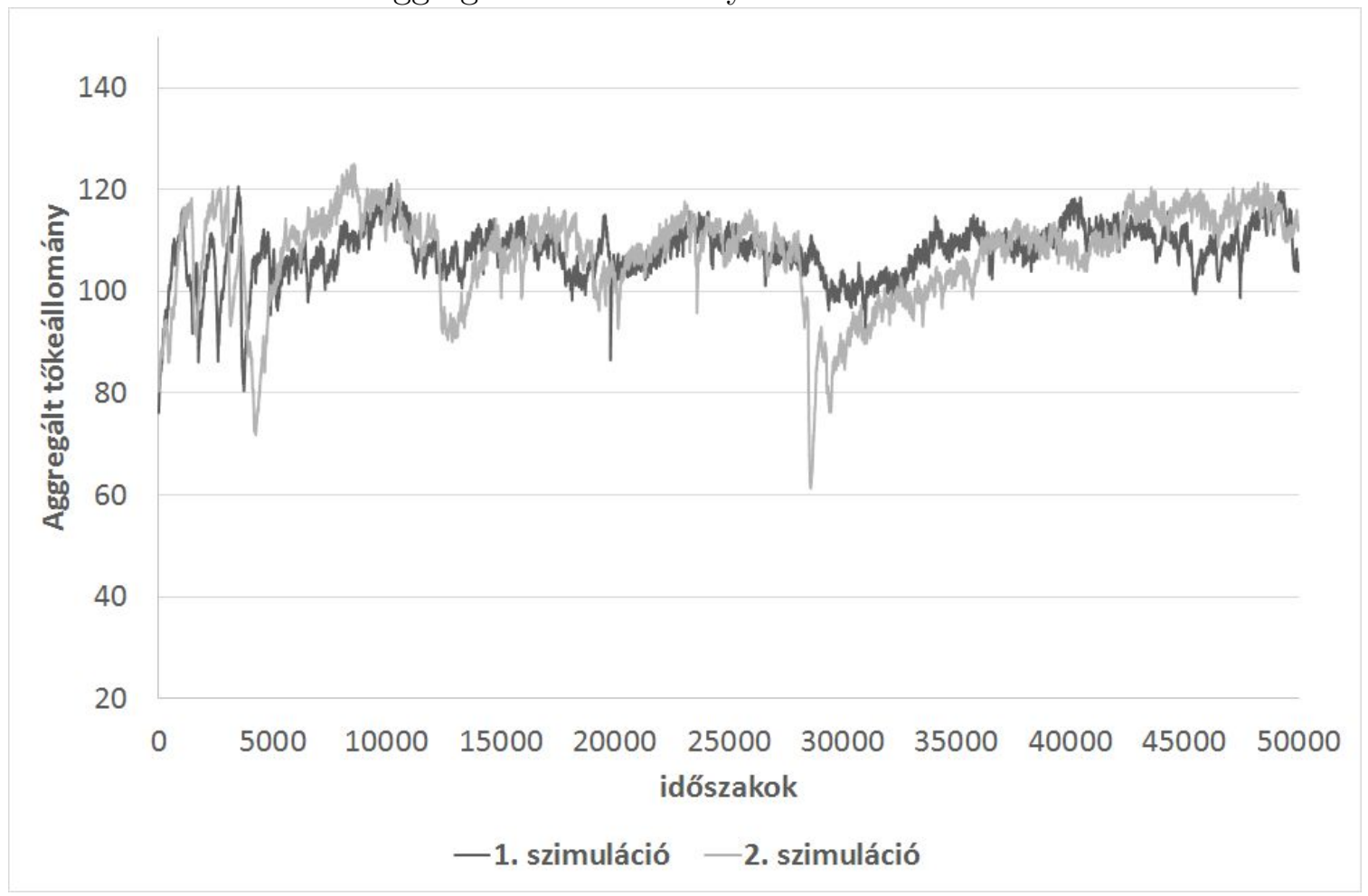

Az 2.1. ábráról leolvasható, hogy $\Upsilon=0,001$ az általunk vizsgált elég hosszú horizonton nem teljesül az ergodicitás (a két görbe nem téveszthető össze), és szigorúan véve a stacionaritás sem, mivel az átlagoknak gyenge trendjük van. Ugyanakkor a trend melletti szóródás elég kicsi. Másfelól a 2. és 3. ábrán azt látjuk, hogy $\Upsilon=10$-nél és $\Upsilon=1000$-nél az ergodicitás nem teljesül, de a stacionaritás talán igen. Itt nincs lassú trend, viszont jóval nagyobb a szóródás, tehát gyanítható, hogy a stacionaritás látszata inkább a "zajból" adódik.

Milyen következtetések vonhatók le ezekból a vizsgálatoktól? A közgazdaságilag releváns időhorizonton a modell effektíve nem stacionárius (tehát nem ergodikus), vagyis egy 5000-es szimulációból kapott átlag nem ad pontos becslést az "igazi" várható értékról, még akkor sem, ha az létezik. Ugyanakkor ez a pontatlanság (ha létezik várható érték) nem feltétlenül túl nagy, és akár létezik várható érték, akár nem, a szimulációs átlagok eloszlása informatív. Nem esetlegesek az eredmények, 
2. fejezet: Három megtakarítói típus: egy adaptív-evolúciós megközelítés

vagy ha úgy tetszik, jó eséllyel jósolhatjuk meg a modell hosszú távú viselkedését nagyságrendi és kvalitatív szinten a paraméterek függvényében.

\section{Eredmények: A típusok életképessége és a gazdaság teljesítménye}

Életképességi rangsor Legfontosabb kérdésünk az, hogy a szelekciós nyomásnak van-e és milyen hatása van arra, hogy mely megtakarítási típusok maradnak fenn hosszú távon a gazdaságban. Ezt vizsgálhatjuk úgy, hogy $\Upsilon$ (a "hőmérséklet") függvényében tekintjük az egyes típusok átlagos számát. Három "fázist" találtunk. Alacsony $\Upsilon$ (nagy szelekciós nyomás) esetén szinte kizárólag prudens típusú háztartások maradnak fenn. A másik véglet a nagy $\Upsilon$, ahol a szelekció gyakorlatilag véletlenszerú, és mindhárom típus közelítôleg egyforma arányban fordul elô a népességben. Végül közepes szelekciós nyomásnál a sorrend az egyes típusok arányában: a legtöbben a prudens ágensek vannak, óket követik a rövidlátók, majd óket, legkisebb arányban, a permanens jövedelem fogyasztók. (A 2.4. táblázat három kiválasztott gamma esetére mutatja a megoszlásokat.) Tehát az "életképességi" rangsor: 1. prudens, 2.rövidlátó, 3. permanens jövedelem.

2.4. táblázat. Az egyes háztartástípusok (prudens, rövidlátó és permanens jövedelem) arányának szimulációkénti átlagai: az átlagok átlaga, minimuma és maximuma a "hốmérséklet" $(\Upsilon)$ különbözô értékei mellett

\begin{tabular}{|l|ccc|ccc|ccc|}
\hline \hline & \multicolumn{3}{|c}{ prudens } & \multicolumn{3}{c}{ rövidlátó } & \multicolumn{3}{c}{ perm. jövedelem } \\
\hline & átl. & $\min$. & $\max$. & átl. & $\min$. & $\max$. & átl. & $\min$. & $\max$. \\
\hline 0,001 & 0,9396 & 0,9303 & 0,9565 & 0,0256 & 0,0134 & 0,0348 & 0,0349 & 0,0208 & 0,0491 \\
10 & 0,4485 & 0,3644 & 0,5967 & 0,3554 & 0,2190 & 0,5134 & 0,1961 & 0,1126 & 0,3787 \\
1000 & 0,3355 & 0,3001 & 0,3821 & 0,3428 & 0,2897 & 0,3899 & 0,3216 & 0,2849 & 0,3714 \\
\hline \hline
\end{tabular}

Életképesség és társadalmi teljesítmény Ez az életképességi rangsor azonban az egyénekre vonatkozik. Igaz-e az, hogy a nagy szelekciós nyomás javítja az egész társadalom teljesítményét is? Erre a válasz nem egyértelmú. Ha az átlagos tôkeállományokat nézzük, akkor azt látjuk, hogy valóban, erôs szelekciós nyomásnál 
a legnagyobb a tőkeállomány, és a szelekciós nyomás csökkenésével csökken. 2.3. táblázat). Azonban a fogyasztásnál (2.5. táblázat) a sorrend megfordul, ha nem is nagy mértékben. Láthatóan a legrosszabb és a legjobb futásokban is az alacsony szelekciós nyomással rendelkezô változat jobb átlagos eredményeket produkált, mint a közepes, és a közepes pedig jobbat, mint a magas szelekciós nyomással rendelkezô változat. Az átlagos fogyasztás mindenképpen jobb mércéjének túnik a gazdasági teljesítménynek, mint a tôkefelhalmozás nagysága, és ebben a metrikában mérve egy adott (zárt) gazdaság számára nem az a legjobb, ha nagy a szelekciós nyomás, és a "relatíve" életképesebb prudens fogyasztók vannak túlsúlyban. Mivel magyarázható ez az elsô látásra furcsának tûnő jelenség?

2.5. táblázat. Az aggregált fogyasztás szimulációnkénti átlagainak átlaga, minimuma és maximuma a "hőmérséklet" $(\Upsilon)$ különbözô értékei mellett, az aranykori fogyasztás százalékában

\begin{tabular}{|l|ccc|}
\hline \hline$\Upsilon$ & átl. & min. & max. \\
\hline 0,001 & 99,10 & 98,36 & 99,62 \\
10 & 99,90 & 99,15 & 100,79 \\
1000 & 100,09 & 99,15 & 100,97 \\
\hline \hline
\end{tabular}

Túlfelhalmozási tendencia Megérthetjük, ha figyelembe vesszük, hogy semmi nem zárja ki a túlzott tókefelhalmozást a modellben, vagyis azt az állapotot, ahol a tőke határterméke kisebb, mint az amortizációs ráta, ami az alapparaméterezésnél 0,005. Az 2.3. táblázat azt mutatja, hogy szimulált gazdaságainkban van túlfelhalmozási tendencia. Láthatóan a túlzott tôkefelhalmozás jelensége nagyobb gyakorisággal fordul elô a nagyobb szelekciós nyomású esetekben. Úgyis fogalmazhatnánk, hogy a nagy szelekciós nyomás túlságosan sok prudens háztartást választ ki, ami a gazdaság egésze szempontjából negatív nettó tőkehozamhoz, azaz túl sok tőkéhez vezet. (A csak munkajövedelemból élők szempontjából a tóke mennyiségének növekedése egyértelmúen pozitív hatású.) Vegyük figyelembe, hogy a puffer nagysága a modellben endogén, vagyis a prudens háztartások hosszú távon endogén módon, szelekció útján határozzák meg azt, hogy mekkora puffer vagyont tartanak. 
A 2.6. táblázat azt mutatja, hogy nagyobb szelekciós nyomás esetén hosszú távon a pufferek mérete nagyobb, vagyis a minél nagyobb biztonságra törekvó ágensek választódnak ki. Ez a megfigyelés azt mutatja, hogy társadalmi szempontból hatékonyság növelố lehet, ha vannak olyan háztartások is, akik némiképpen ellensúlyozzák a prudens háztartások túlfelhalmozási tendenciáit. Ugyanakkor a kapcsolat nem monoton, közepes szelekciós nyomásnál a legnagyobbak a vagyonpufferek. A tôke azért nem a közepes hômérsékletnél a legnagyobb, mivel a prudens háztartások vagyona tartalmazza az általuk nyújtott hitelek állományát is. A 2.7. táblázat mutatja, hogy alacsony $\Upsilon$-nál a hitelállomány alacsony, míg közepes $\Upsilon$-nál, ahol már vannak nem elhanyagolható mértékben rövidlátó háztartások is, magasabb.

2.6. táblázat. A puffer méret szimulációnkénti átlagainak átlaga, minimuma és maximuma a "hômérséklet" $(\Upsilon)$ különbözô értékei mellett

\begin{tabular}{|l|ccc|}
\hline \hline$\Upsilon$ & átl. & $\min$. & $\max$. \\
\hline 0,001 & 114,18 & 105,85 & 127,63 \\
10 & 153,31 & 116,35 & 181,66 \\
1000 & 126,68 & 94,07 & 145,36 \\
\hline
\end{tabular}

2.7. táblázat. Az adósságráta $(D / Y)$ szimulációnkénti átlagainak átlaga, minimuma és maximuma a "hőmérséklet" $(\Upsilon)$ különböző értékei mellett

\begin{tabular}{|l|ccc|}
\hline \hline$\Upsilon$ & átl. & min. & max. \\
\hline 0,001 & 0,8894 & 0,6675 & 1,0563 \\
10 & 2,3551 & 2,0390 & 2,6690 \\
1000 & 2,5111 & 2,3484 & 2,7113 \\
\hline \hline
\end{tabular}

Felvetődhet, hogy a túlberuházási tendenciát az okozza, hogy a kezdeti puffer eloszlás várható értékét túl nagyra állítjuk (120 periódus). Ezért megnéztük, hogy mi történik, amikor ezt a negyedére csökkentjük, azaz 30 periódusra. A 2.4 ábrából láthatóan hosszú távon a tôkeállomány itt is mintegy 20 \%-kal meghaladja az aranykorit, a vagyon pufferek endogén növekedésének köszönhetően. 
2.4. ábra. Az aggregált tókeállomány alakulása $\bar{h}=30$ és $\Upsilon=10$ mellett

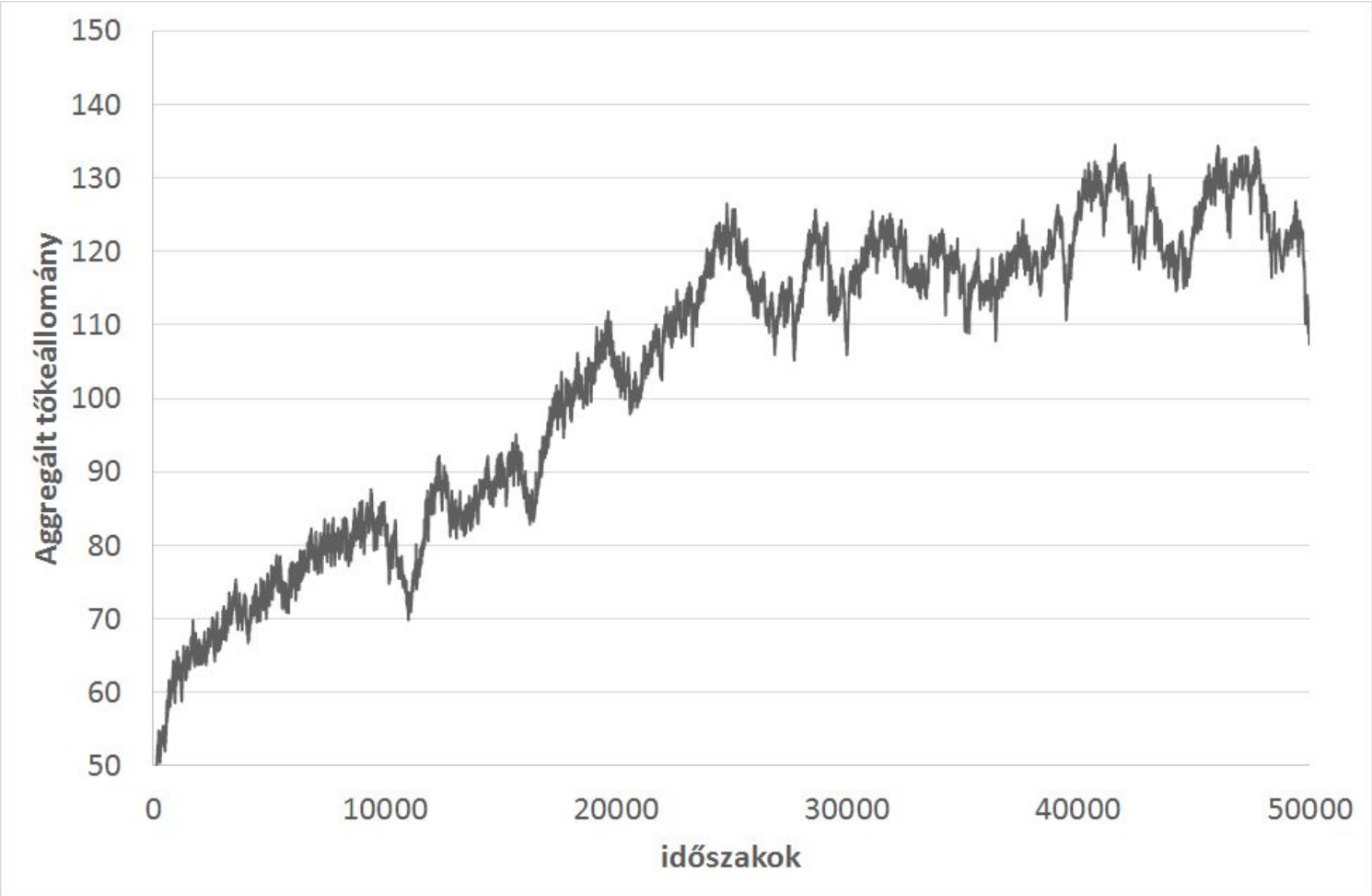

Katasztrófák és túlfelhalmozás Elsô látásra furcsa lehet az, hogy túlfelhalmozási tendenciát találunk. Megszoktuk, hogy inkább attól félünk túl alacsonyak a megtakarítások. Nem szabad azonban elfelejtenünk, hogy itt zárt gazdaságot vizsgálunk, és a világgazdaság például a XXI. század elején is megtakarítási túlkínálatot (savings glut) mutatott, vagyis az alacsony megtakarítási ráták lokális problémák voltak. Hosszabb történelmi távlatban is gyanús lehet azonban az a következtetés, hogy az emberiségnek hajlama van a túlzott tőkefelhalmozásra. Modellünk célja nem egy általános gazdaságtörténeti magyarázat, de egy ehhez kapcsolt részkérdést megvizsgáltunk. A történelem során gyakran voltak olyan katasztrófák (természeti vagy háborús), amelyek a tôke mennyiségének hirtelen csökkenéséhez vezettek. Egy olyan modellt is szimuláltunk (mindhárom fázisban), ahol 1 százalékos valószínúséggel valamely periódusban a társadalmi tôke 10 százalékkal csökken. Azt kapjuk, hogy ez a jelenség a kívánt puffer szintet csökkenteni fogja (nem éri meg egyénileg nagy tókét felhalmozni). (Lásd 2.9. táblázat). Tehát a 
2. fejezet: Három megtakarítói típus: egy adaptív-evolúciós megközelítés

túlfelhalmozási tendenciát korlátozhatja a tóke effektív termelékenységének csökkenése, vagyis sok, nagy katasztrófával terhelt időszakokban nem jut feltétlenül érvényre a túlfelhalmozási tendencia.

2.8. táblázat. Az aggregált tôkeállomány szimulációnkénti átlagainak átlaga, minimuma és maximuma a "hőmérséklet" $(\Upsilon)$ különböző értékei mellett, katasztrófák esetén, az aranykori tókeállomány százalékában, katasztrófák esetén

\begin{tabular}{|l|ccc|}
\hline \hline$\Upsilon$ & átl. & min. & max. \\
\hline 0,001 & 111,39 & 104,85 & 120,37 \\
10 & 90,41 & 79,29 & 99,16 \\
1000 & 78,99 & 69,14 & 88,56 \\
\hline \hline
\end{tabular}

2.9. táblázat. A puffer méret szimulációnkénti átlagainak átlaga, minimuma és maximuma a "hômérséklet" $(\Upsilon)$ különböző értékei mellett, katasztrófák esetén

\begin{tabular}{|l|ccc|}
\hline \hline$\Upsilon$ & átl. & min. & max. \\
\hline 0,001 & 105,51 & 96,26 & 117,88 \\
10 & 115,57 & 99,41 & 132,46 \\
1000 & 100,97 & 77,87 & 115,36 \\
\hline \hline
\end{tabular}

Kockázat Eddigi eredményeink mintha azt mondanák, hogy a társadalmi és az egyéni racionalitás ellentmond egymásnak. Van-e valamilyen kimutatható társadalmi eloonye annak, ha a szelekciós kényszer erôsebb? Igen, mégpedig az, hogy magasabb szelekciós kényszer esetén az egyes pályák sokkal stabilabbak, mint alacsony szelekciós kényszernél. Az 2.1 2.3. ábrákon jól látszik, hogy az egyes szimulációkban jóval nagyobb ingadozások vannak olyankor, amikor nem elhanyagolható mértékú rövidlátó és permanens jövedelem fogyasztó is van a gazdaságban, az alacsonyabb szelekciós kényszernek betudhatóan. Amennyiben tehát nemcsak a hosszú távú átlag számít egy zárt populáció gazdasági sikeressége szempontjából, akkor az egyéni és társadalmi racionalitás egymással már inkább összhangban 
vannak. Ha az alacsony gammás szimulációt túl stabilnak tartanánk, akkor emlékezzünk rá, hogy a modell csak egyéni exogén bizonytalanságot tartalmaz. Egy klasszikus modellból generált idôsorok majdnem determinisztikusak lennének.

Intranzitív életképesség Megvizsgáltuk azt is, hogy mi történne, ha a három típus helyett eleve csak kettő létezne. A 2.10. táblázat mutatja a kialakuló népesség megoszlásokat közepes szelekciós nyomásnál, amikor is egy-egy "nagyon hosszú" (50000-es) szimulációt futtattunk. Láthatóan a három típus "körbeveri" egymást. A permanens jövedelem-rövidlátó kombinációknak van egy speciális vonása: nagyon hosszú szimulációknál ebben az esetben szinte biztosan van egy olyan periódus, ahol a társadalmi tőke állománya 0-ra csökken. Mondhatjuk azt is, hogy prudens fogyasztók nélkül mintegy hosszabb távon életképtelen a gazdaság. Mi történik, ha csak prudens és rövidlátó fogyasztók vannak? Ilyenkor többségben lesznek a rövidlátó fogyasztók, ami, talán meglepó módon, de nem növeli a fogyasztás ingadozását. Úgy túnik tehát, hogy a prudens és a rövidlátó típusnak is van "hasznos" funkciója. Prudensek nélkül hosszú távon nincs tőkefelhalmozás, a rövidlátók mérséklik a túlfelhalmozási tendenciát. A permanens jövedelem fogyasztók életképesek, részben kiszorítják a rövidlátó típusokat, de nekik csak akkor lenne "pozitív" szerepük, ha a tôkefelhalmozás túl alacsony lenne.

2.10. táblázat. Az egyes háztartástípusok (prudens $(p r)$, rövidlátó ( $r l$ és permanens jövedelem $(p j))$ arányának szimulációkénti átlagai $(\Upsilon=10)$, amikor egy típus nem vesz részt a "versenyben"

\begin{tabular}{|l|ccc|}
\hline \hline Típuspár & prudens & rövidlátó & perm. jövedelem \\
\hline pj-rl & 0 & 0,2519 & 0,7481 \\
pj-pr & 0,7556 & 0 & 0,2444 \\
pr-rl & 0,3880 & 0,6120 & 0 \\
\hline \hline
\end{tabular}

A hitelkorlát szerepe Az alapmodellben alapvetôen nem foglalkoztunk a tôkepiac szerepével a megtakarításokban. A hitelkorlátot elég szigorúra vettük ahhoz, hogy az eredményként adódó adósságráták csak nagyon alacsonyak legyenek (lásd 
2. fejezet: Három megtakarítói típus: egy adaptív-evolúciós megközelítés

2.7. táblázat.) Mint várható is, az adósság túlnyomó részét a rövidlátó fogyasztók "vállalják". Kipróbáltunk azonban olyan változatokat is, ahol megengedünk jóval nagyobb ("irracionálisan" nagy) eladósodást is, az adósságkorlátot az alapváltozatbeli 10-szeresére növelve. Az ebben a változatban kialakuló adósságszintek jóval nagyobbak, habár nem érik el az eredeti 10-szeresét, és természetesen újra a rövidlátó fogyasztók vesznek fel fóként hitelt.2.11. táblázat.) A hitelkorlát oldása nem vezet az átlagfogyasztás növekedéséhez, hanem inkább csökkenti azt. Érdekes azonban a mechanizmus: az átlagfogyasztás csökkenésének oka nem az alulfelhalmozás, hanem a még nagyobb túlfelhalmozás. (2.12. táblázat.) Tehát, ha a tôkepiacok "megőrülnek" (a modellben "centralizált" tôkepiac van, ami szinte egyetlen rendszerként funkcionál, nem vezethetô vissza a múködése az egyes ágensek viselkedésére), akkor az ágensek társadalmilag még kevésbé hatékony túlfelhalmozással válaszolnak, ami mintegy lehetôvé teszi a rövidlátók által történô még erôteljesebb "kizsákmányolásukat". (Itt a munkás zsákmányolja ki a tőkést.) Természetesen előfordulhatna az is, hogy az aranykor felé mutatna a változás, de ahhoz alulfelhalmozásos alappályából kellene indulnunk. Ha ez előállna például nagy katasztrófák (alacsony effektív hosszútávú tôkehozam) hatására, akkor a tókepiaci "ôrültség" hatása akár még pozitív is lehetne összességében.

2.11. táblázat. Az adósságráta $(D / Y)$ szimulációnkénti átlagainak átlaga, minimuma és maximuma a "hőmérséklet" $(\Upsilon)$ különbözô értékei mellett alacsony és magas hitelkorlát $(\bar{D})$ mellett

\begin{tabular}{|l|ccc|ccc|}
\hline \hline & \multicolumn{3}{|c}{ alacsony $\bar{D}$} & \multicolumn{3}{c}{ magas $\bar{D}$} \\
\hline$\Upsilon$ & átl. & $\min$. & $\max$. & átl. & min. & $\max$. \\
\hline 0,001 & 0,8894 & 0,6675 & 1,0563 & 3,5668 & 3,4402 & 3,7366 \\
10 & 2,3551 & 2,0390 & 2,6690 & 4,9472 & 4,4766 & 5,7069 \\
1000 & 2,5111 & 2,3484 & 2,7113 & 5,4875 & 5,3843 & 5,5855 \\
\hline \hline
\end{tabular}


2.12. táblázat. Az aggregált tőkeállomány szimulációnkénti átlagainak átlaga, minimuma és maximuma a "hômérséklet" $(\Upsilon)$ különbözô értékei mellett alacsony és magas hitelkorlát $(\bar{D})$ mellett

\begin{tabular}{|l|ccc|ccc|}
\hline \hline & \multicolumn{3}{|c}{ alacsony $\bar{D}$} & \multicolumn{3}{c}{ magas $\bar{D}$} \\
\hline$\Upsilon$ & átl. & min. & $\max$. & átl. & $\min$. & $\max$. \\
\hline 0,001 & 130,51 & 127,10 & 133,76 & 154,26 & 149,96 & 162,05 \\
10 & 115,45 & 105,80 & 124,89 & 226,57 & 198,49 & 263,26 \\
1000 & 100,15 & 79,93 & 113,21 & 234,77 & 159,22 & 270,25 \\
\hline \hline
\end{tabular}

\section{6. Összegzés}

Úgy tûnik csak rendkívül erôs szelekciós nyomás mellett mondhatjuk azt, hogy a prudens típus egyértelmúen kiszorítja a másik kettót. Az eddigi megtakarításokkal kapcsolatos kutatások eredményeit azonban nehéz lenne úgy interpretálni, hogy a gazdaságok kizárólag prudens háztartásokból állnak. A (furcsa módon) második legéletképesebbnek tưnő rövidlátó típusnak feltétlenül helye van egy ágens-alapú makromodellben. A rövidlátó típus konkrét modellezésére a jelen tanulmányban megfogalmazott változat nem feltétlenül az egyetlen célravezető, itt még sok kutatásra van szükség. Amennyiben kihagyjuk a permanens jövedelem típust, akkor annak az a következménye, hogy arra számíthatunk, hogy a rövidlátó típusnak kell "dominálnia".

Szokásos tôkehatékonyság ( $\alpha=0,33)$ mellett a prudens típus túlberuházási tendenciát ad a gazdaságnak. Ha az az empirikus alapfeltevésünk, hogy a reálkamatláb nagyobb, mint a növekedési ütem, akkor ezt valahogyan más tényezókbool kell levezetni, nem lehet a háztartások viselkedésére (preferenciáira) hivatkozni, mint a hagyományos modellekben, ahol az időpreferencia paraméternek kulcsszerepe van abban, hogy a gazdaság az aranykori megtakarítási ráta melyik oldalán helyezkedik el. 
Az ágens-alapú makromodellek általában mellôzni szokták a háztartási adósság (fogyasztási hitelek) problémáját. Ezek azonban korántsem elhanyagolhatóak a valós gazdaságok életében. Szimulációink ezzel kapcsolatban egy talán meglepó eredménnyel jártak. A hitelkorlátok oldása nem az aggregált megtakarítási ráta hosszú távú csökkenéséhez, hanem növekedéséhez vezet. 


\section{3. fejezet}

\section{Parametrikus nyugdíjreformok és életciklus-munkakínálat}

\subsection{Bevezetés}

A társadalombizosítási nyugdíjrendszer fenntarthatóságának szavatolása az egyik legjelentôsebb előrejelezhetô teher a fejlett országok költségvetése számára hosszú távon. A születéskor várható élettartam emelkedése, a termékenységi ráták hullámzó csökkenése miatt a potenciális járulékfizetóknek a nyugdíjjogosultakhoz viszonyított száma csökken, ezért a nyugdíjak felosztó-kiróvó elveken történó finanszírozása számottevố nehézséget okoz. Több ország a nyugdíjrendszerének az átgondolásával, a nyugdíjrendszer paramétereinek a szigorításával reagál a kihívásokra. A problémát ugyanakkor sok fejlett országban, így Magyarországon sem pusztán a kedvezőtlen demográfiai tendenciák jelentik, hanem a munkaképes korú népesség alacsony aktivitása/foglalkoztatása.

A nyugdíjrendszer fenntarthatóságának alakulásáról, nyugdíjreformok hatásairól Magyarországon már többen készítettek előrejelzést (például Orbán, Palotai [2006] és Holtzer szerk. [2010]). Ezekben a munkapiaci folyamatok leírásánál a gazdasági szereplők viselkedése a múltban megfigyelt mintákat követi. A fog- 
lalkoztatási viszonyok nyugdíjakra gyakorolt hatásával a magyar irodalomban elsôsorban Augusztinovics Mária munkái foglalkoztak (pl. Augusztinovics [2005], Augusztinovics-Köllő [2007] és Augusztinovics, Gyombolai, Máté [2008]). Az írások alapvetően tényfeltáró jellegúek, hasznos ismereteket szerezhetünk belőlük a foglalkoztatási és járulékfizetési összefüggésekrôl. Előreszámításaik során megközelítésükben közös, hogy a foglalkoztatási viszonyok tekintetében a keresztmetszeti korprofilok továbbélését, szintbeli eltolódását feltételezik, vagy szintén exogén, időtől és állapottól független Markov-féle átmenet-mátrixokat használnak az egyes foglalkoztatási kategóriák (Augusztinovics [2005] szóhasználatával: alfák, béták és gammák) közötti átmenet jellemzésére.

Hosszú távon a nyugdíjrendszer reformjaira adott viselkedési, munkakínálati reakciók azonban fontosak lehetnek a nyugdíjrendszer fenntarthatósága szempontjából. A tanulmány megközelítése a korábban a nyugdíjrendszer és a foglalkoztatás viszonyát vizsgáló írásokhoz képest ezért abban tér el, hogy nem csak azt szeretné vizsgálni, hogy a foglalkoztatottsági viszonyok hogyan hatnak a nyugdíjakra, hanem azt is, hogy a nyugdíjrendszer (más ösztönzôkkel együtt) hogyan hat az életciklus-munkakínálatra. 
3.1. ábra. Az 55-64 éves korosztály foglalkoztatottsági rátái 2011-ben az Európai Unióban

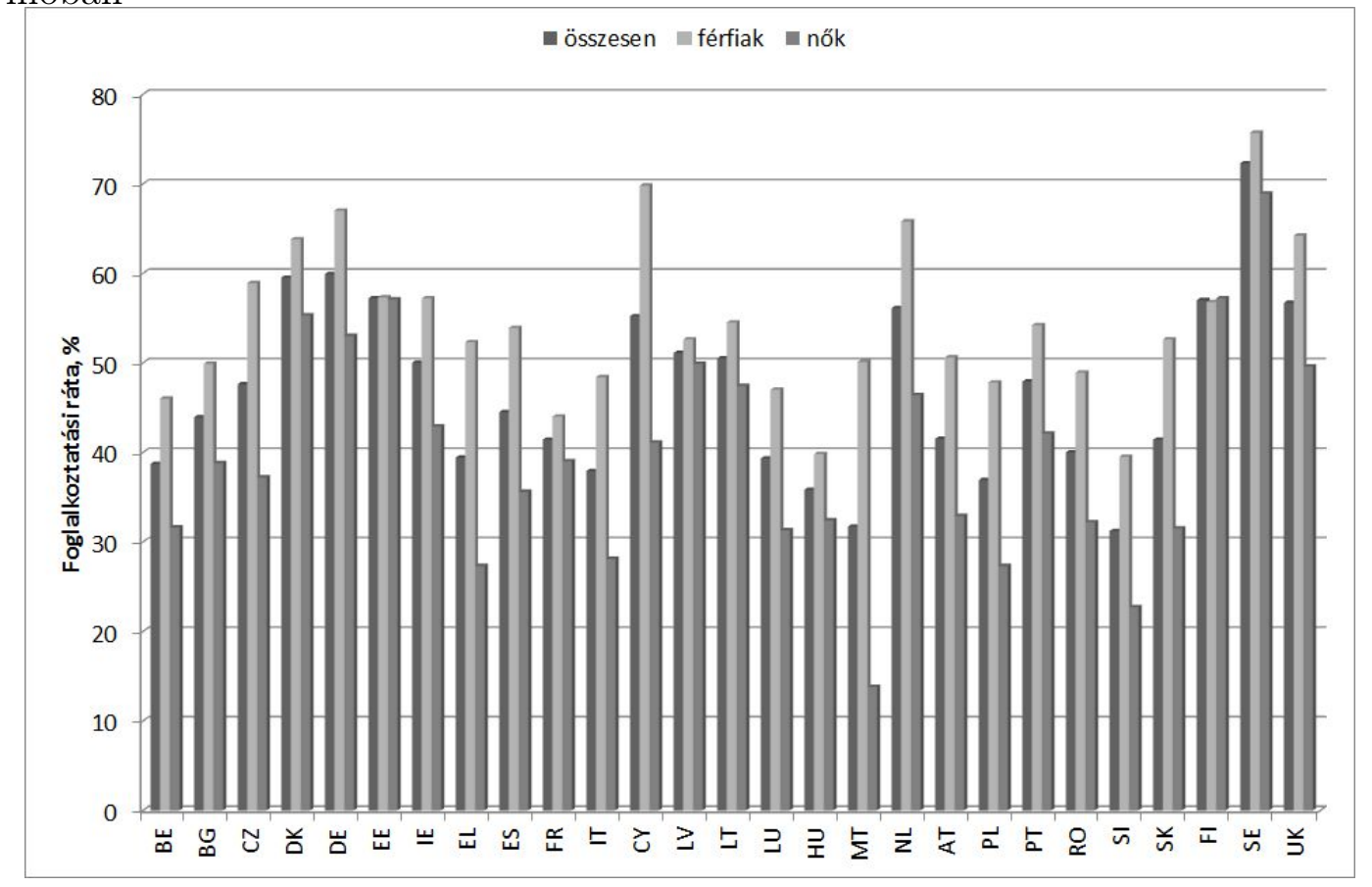

Forrás: Eurostat

Az életciklus-munkakínálat mögött meghúzódó tényezôk hatásainak elemzését a nyugdíjrendszer fenntarthatósága mellett önmagában fontossá teszi az is, hogy valószínúleg részben a nyugdíjrendszernek köszönhetően - Magyarországon az idósebb korosztályok foglalkoztatottsága az Európai Unión belül rendkívül alacsony. 2011-ben az 55-64 évesek foglalkoztatottsági rátája 35,8 százalék volt, melyet csak Málta $(31,7)$ és Szlovénia $(31,2)$ múlt alul (3.1. ábra). Szúkebb környezetünkben valamennyi ország (például Románia, Szlovákia, Csehország) mutatója magasabb: 40 százalék feletti. Magyarország relatív pozíciója a férfiak tekintetében rosszabb az 55-64 éves korosztály foglalkoztatottsági rátájánál (39,8 százalék) csak a szlovén érték alacsonyabb (39,5 százalék), míg a nők esetében 9 ország foglalkoztatottsági rátája is kisebb a magyarnál (32,4 százalék).

A nyugdíjrendszer és az időskori munkakínálat, valamint az életciklus-munkakínálat közötti kapcsolat ok-okozati elemzésének két alapvetô irányzatát ismerjük. Az 
egyik megközelítés redukált formájú ökonometriai becsléseket végez. Gruber, Wise [2004] által összegzett országtanulmányok 12 fejlett ország társadalombiztosítási nyugdíjrendszerének a nyugdíjba vonulás valószínúségére gyakorolt ösztönzô hatását vizsgálták. A tanulmányok közös következtetése, hogy a nyugdíjrendszer marginális ösztönzô hatásai negatívan befolyásolják a munkaerôpiaci részvételt. Manoli, Mullen, Wagner [2011] az osztrák nyugdíjrendszerben rejlő ösztönzô hatásokat számszerúsíti. A szerzók a munkaerôpiaci részvételre gyakorolt hatás tekintetében a marginális ösztönzô hatást még jelentősebbnek találták, mint a korábbi tanulmányok. Cseres-Gergely [2007] a szegényesebb magyar adatokon próbált hasonló vizsgálatokat folytatni, és a várható nyugdíj értékének a pozitív hatását mutatta ki a nyugdíjba vonulási döntésre. Benczúr, Kátay, Kiss [2012] egy mikroszimuláció keretében a magyar adó- és transzferrendszer változásai között megvizsgálja a nyugdíjkorhatár emelésének aktivitásra gyakorolt hatását. Az eredmények szerint az effektív nyugdíjkorhatár 1 éves megemelése összességében 4,26 százalékponttal emeli meg az 55-65 éves korosztály foglalkoztatottsági arányát.

A másik megközelítés, melynek hagyományait írásunk is igyekszik követni, az életciklus-munkakínálot dinamikusan optimalizáló szereplők döntéséból vezeti le!1 A társadalombiztosítási nyugdíjrendszer, mint elsődleges ösztönző szerepel Rust, Phelan [1997] és Manoli, Mullen, Wagner [2011] tanulmányaiban: a nyugdíjrendszer változásai hatással vannak az idősebb férfiak munkakínálatára, illetve nyugdíjba vonulási döntésére. French [2005] a férfiak teljes életciklus-munkakínálatát igyekszik leírni egy olyan modell felhasználásával, ahol a munkakínálatot a nyugdíjrendszer mellett az egészségi állapot változásai is meghatározzák. Mindhárom tanulmány strukturális becsléssel határozza meg a modell kulcsparamétereit. A magyar irodalomban Simonovits [2012] kétidôszakos modelljében - amelyben az optimalizáló szereplők jóléte fogyasztásuk mellett szabadidő-fogyasztásuktól is függ - a kiegyensúlyozott költségvetés a nyugdíjjárulékért és jövedelemadóért cserébe a nyugdíjasoknak keresetarányos nyugdíjat, a dolgozóknak és nyugdíjasoknak alapjövedelmet biztosít. Eredménye szerint a társadalmi jólétet maximalizáló adó- és járulékkulcs egyensúlyt teremt a keresetarányos nyugdíjrendszer hatékonysága, munkakínálatot ösztönzố hatása és az alapjövedelem adta újraelosztás között.

\footnotetext{
${ }^{1}$ A férfiak életciklus-munkakínálati modelljeinek jó összefoglalóját adja Keane [2011].
} 
3. fejezet: Parametrikus nyugdíjreformok és életciklus-munkakínálat

Tanulmányunkban egy életciklusmodell alapjait szeretnénk lefektetni. A modellben kizárólag a férfiak munkakínálatára koncentrálunk, a nôi életciklus-munkakínálattal az azt befolyásoló, nehezebben modellezhetô tényezók (család, jövedelemkiegészítés) miatt nem foglalkozunk. A modellben két fontos elem van, amely a munkakínálatra hat. Az egyik a magyar adatokból becsült termelékenységi profil. Mind a termelékenységi profilok, mind a foglalkoztatási/aktivitási görbék jelentős eltérést mutatnak az eltérő képzettségü férfiak között, ezért három képzettségi csoport termelékenységét és munkakínálatát külön elemezzük. A termelékenység mellett a modell másik fontos jellemzője, hogy a szereplők nyugdíja az aktív munkapiaci életük során megszerzett nettó bérjövedelmükön alapul, amit munkakínálati döntéseikben figyelembe vesznek.

A modell a munkakínálat magyarázatára emellett más tényezóket, például különbözô adókat is bevon. Ugyanakkor így sem gondoljuk, hogy jelen állapotában megfelelô részletezettséggel tartalmazza az összes olyan összetevôt, amely a férfiak munkakínálatát befolyásolja az életpálya vagy annak csak kései szakasza során. Maga a nyugdíjrendszer ábrázolása is egyszerú, nem terjed ki az egyébként roppant bonyolult magyar nyugdíjrendszer számos, munkakínálatot egészen biztosan befolyásoló elemére (a vizsgált időszakban például az előrehozott nyugdíj lehetôségére). Másrészt a nyugdíjrendszeren kívül is hiányoznak olyan tényezôk (például egyéb transzferek), amelyek hatnak, és bár létezik adózás, a munkajövedelem-adózás nem tartalmaz progressziót. A fenti hiányosságok a modellfejlesztés természetes evolúciójának a számlájára írhatók, a jövóben szeretnénk kiküszöbölni óket.

A nyugdíjreformok makroökonómiai és költségvetési hatásainak szimulálására gyakran használnak Auerbech, Kotlikoff [1987] megközelítésére építő, együttélő korosztályokat tartalmazó makroökonómiai modelleket. A dolgozat záró fejezete felvázol egy együttélő korosztályokat tartalmazó keretet, amelyben a demográfiai átmenet és parametrikus nyugdíjreformok hatását elemzi. Az említett modelleknek egy fontos alkotóeleme az egyes háztartások életciklusának a modellezése, amelyben a munkakínálat endogén módon alakul. Bár ebben az írásban kizárólag az életciklus-munkakínálat parciális, mikroökonómiai témájával foglalkozunk, 
a felépített életciklus modell a késôbbi, együttélő korosztályokat tartalmazó makroökonómiai modell alapját képezi.

A továbbiakban a fejezet a következő felépítést követi. A második részben felvázoljuk azokat az átlagos munkakínálati korprofilokat, melyeket a késóbbiekben a modell segítségével magyarázni igyekszünk. A harmadik részben ismertetjük a magyar társadalombiztosítás öregségi és rokkantsági nyugdíjrendszerének azon elemeit, amelyekrôl feltételezhető, hogy hatnak a munkakínálatra, másrészt leíró statisztikákra támaszkodva érvelünk amellett, hogy legalábbis idôsebb korban a nyugdíjrendszer a foglalkoztatás egyik meghatározó tényezője lehet. A negyedik részben ismertetjük az alkalmazott elméleti modell felépítését, az ötödikben kalibráljuk a modell paramétereit. A hatodik részben megvizsgáljuk, hogy a nyugdíjrendszer parametrikus reformjai miként hatnak a modellbéli életciklus-munkakínálatra, majd a hetedikben összefoglaljuk a tapasztalatokat, és vázoljuk a később szükséges bôvítési irányokat.

\subsection{A férfiak munkaóráinak korprofiljai 1999 és 2009 között}

A nyugdíjrendszer és az életciklus-munkakínálat közötti kapcsolat elemzését, modellezését megelőzően bemutatjuk a magyar férfiak munkaóráinak életkor szerinti mintázatait 1999 és 2009 között. A statisztikák előállításához a Központi Statisztikai Hivatal munkaerô-felmérésének (Labor Force Survey: LFS) adatait használtuk. ${ }^{2}$ A KSH 1992 óta készít felmérést a 15-74 évesek foglalkoztatási és munkanélküliségi viszonyainak mérésére. Bár a negyedévente megjelenő munkaerő-felmérésekben hat negyedévig nyomon követik a megfigyelteket, az adatbázisnak csak a keresztmetszeti dimenzióját használtuk ki. A vizsgálat során 1999 és 2009 közötti átlagos adatokról írunk. Ugyan a kiválasztott idôszakban sem volt változatlan a nyugdíjrendszer, de az 1997. évi, illetve a 2010-et követô még jelentősebb változásokhoz

\footnotetext{
${ }^{2} \mathrm{Az}$ adatokhoz a Magyar Nemzeti Bank Nyári Vendégkutatói Programja jóvoltából fértünk hozzá 2012-ben.
} 
3. fejezet: Parametrikus nyugdíjreformok és életciklus-munkakínálat

képest az 1999-2009-es idôszakon belül lezajlott változások kisebbnek tekinthetôk. A vizsgálat során a 26 és 70 év közötti korosztályokra figyeltünk, az évjáratokat ötévenként összevonva. A munka statisztikai mérésere az egy évben ledolgozott órákat használtuk. $]^{3}$ Az egy évben ledolgozott munkaórák számát egyszerúen a heti munkaórák 52-szereseként nyertük. A hagyományos megközelítésnek megfelelően az összes munkaóra életkor szerinti változását két összetevőre bontjuk: a foglalkoztatottak arányának, valamint a foglalkoztatottak által ledolgozott órák számának változására 4

A bemutatott empirikus megfigyelések kapcsán ki kell emelnünk, hogy a vizsgálat során nem rendelkeztünk olyan egyéni szintú adatokkal, amelyek alapján hosszmetszetben jellemezni tudtuk volna a különböző képzettségú férfiak egyes korcsoportjainak az életciklusmunkáját, ezért a következtetéseink megfogalmazása során keresztmetszeti megfigyelésekre támaszkodtunk 5

\footnotetext{
${ }^{3}$ A kérdőív külön kérdez rá a főállásban és a másodállásban eltöltött órákra, melyeket összevonva kezelünk.

${ }^{4}$ A munkakínálat irodalmában két munkakínálati döntést különböztetnek meg: az alkalmazkodás extenzív határát, amikor arról dönt a munkavállaló, hogy dolgozik-e, és az alkalmazkodás intenzív határát, amikor arról dönt a foglalkoztatott, hogy mennyit dolgozik. Aggregált szinten az elóbbit a foglalkoztatottak arányával, utóbbit az egy foglalkoztatottra jutó munkaórák számával mérik.

${ }^{5}$ A keresztmetszeti adatok csak akkor közelítik jól az idősoros értékeket, ha a gazdaság közel stacionárius, azaz a keresztmeszeti megfigyelések korprofilja időben hozzávetőlegesen továbbél. Augusztinovics, Gyombolai, Máté [2008] által használt 1997 és 2006 közötti járulékfizetési történetek tíz évet tudnak lefedni egy életpályából. Egy fontos hiányossága azonban az általuk használt Kelen-adatbázisnak, hogy nem tartalmaz iskolai végzettségre utaló változókat, ezért iskolai végzettség szerinti bontásban a munkaórák korprofiljai Kelen-adatbázissal nem vizsgálhatók. Bálint, Köllő, Molnár [2010] által használt ONYF-KSH adatbázis még hosszabb, teljes munkatörténeteket és számos egyéb egyéni és környezeti változót tartalmaz. A mintegy kilencezer főt tartalmazó adatbázishoz azonban nem volt hozzáférésünk.
} 
3.2. ábra. A férfiak átlagos egy fơre jutó munkaórái, foglalkoztatottsági rátái és egy munkásra jutó munkaórái, 1999-2009.
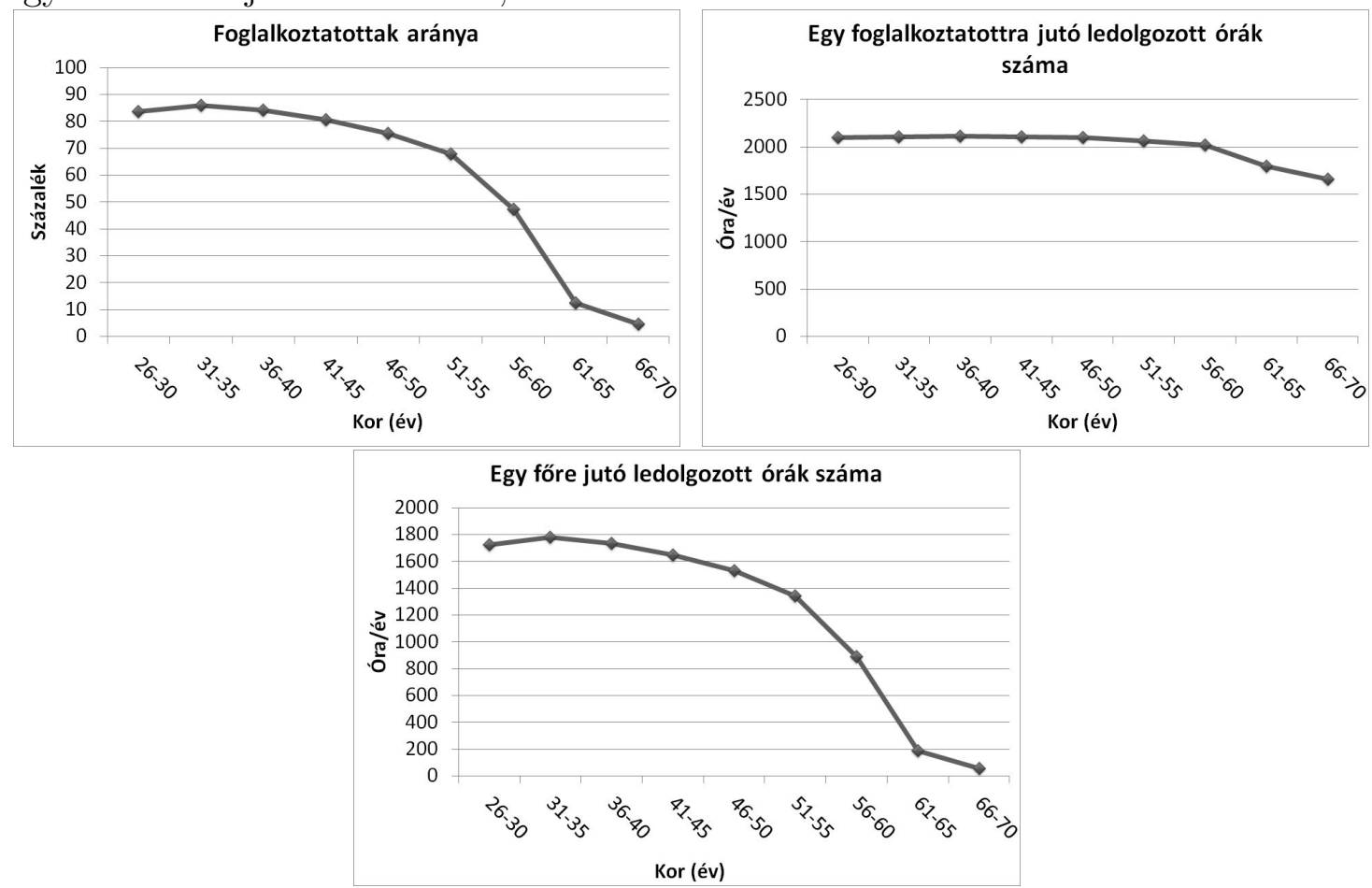

Forrás: saját számítás a KSH munkaerô-felmérése alapján

Az összes megfigyelt évet együtt kezelve látható, hogy az egy évben ledolgozott munkaórák száma a 31-35 éves korosztálynál a legmagasabb, mintegy 1780 óra (3.2. ábra). Ezt követően az órák száma körülbelül 50 éves korig lassabb ütemben, majd gyorsabb ütemben csökken. Az intenzív határon a foglalkoztatottak által ledolgozott munkaórák száma egészen az 56-60 éves korosztályig évi 2000 és 2100 óra között marad, és csak a 60 évnél idősebbeknél csökken jelentősen (körülbelül 1650 órára). Az összes munkaóra korprofilja elsősorban a foglalkoztatottak arányát követi. A ráta a 31-35 éves férfiak körében a legmagasabb, mintegy 86 százalék, majd 51-55 éves korra már 67,8, 56-60 éves korra 47,3 százalékra csökken.

Ha a munkaórák korosztály szerinti eloszlásának idôbeli változását is szemügyre vesszük kiválasztva az 1999., 2004. és 2009. éveket (Függelék 8.1. ábra), akkor láthatjuk, hogy a megfigyelt időszakban a ledolgozott órák száma a legfiatalabb, 26-30 éves korosztályban az időszak során 1800-ról 1600 órára csökkent, az idősebb 
korosztályok közül pedig az 56-60 éves korosztályé 690-rôl 940-re, a 61-65 éves korosztályé 115-rôl 190 órára nótt. Fiatal korban mind az extenzív, mind az intenzív határon változás történt, idôs korban viszont csak a foglalkoztatottak aránya emelkedett (56-60 éves korban 36 százalékról 50 százalékra, 61-65 éves korban 8,3-ról 13 százalékra nôtt).

3.3. ábra. A férfiak átlagos egy fôre jutó munkaórái és azok összetevôi képzettségi csoportonként, 1999-2009.
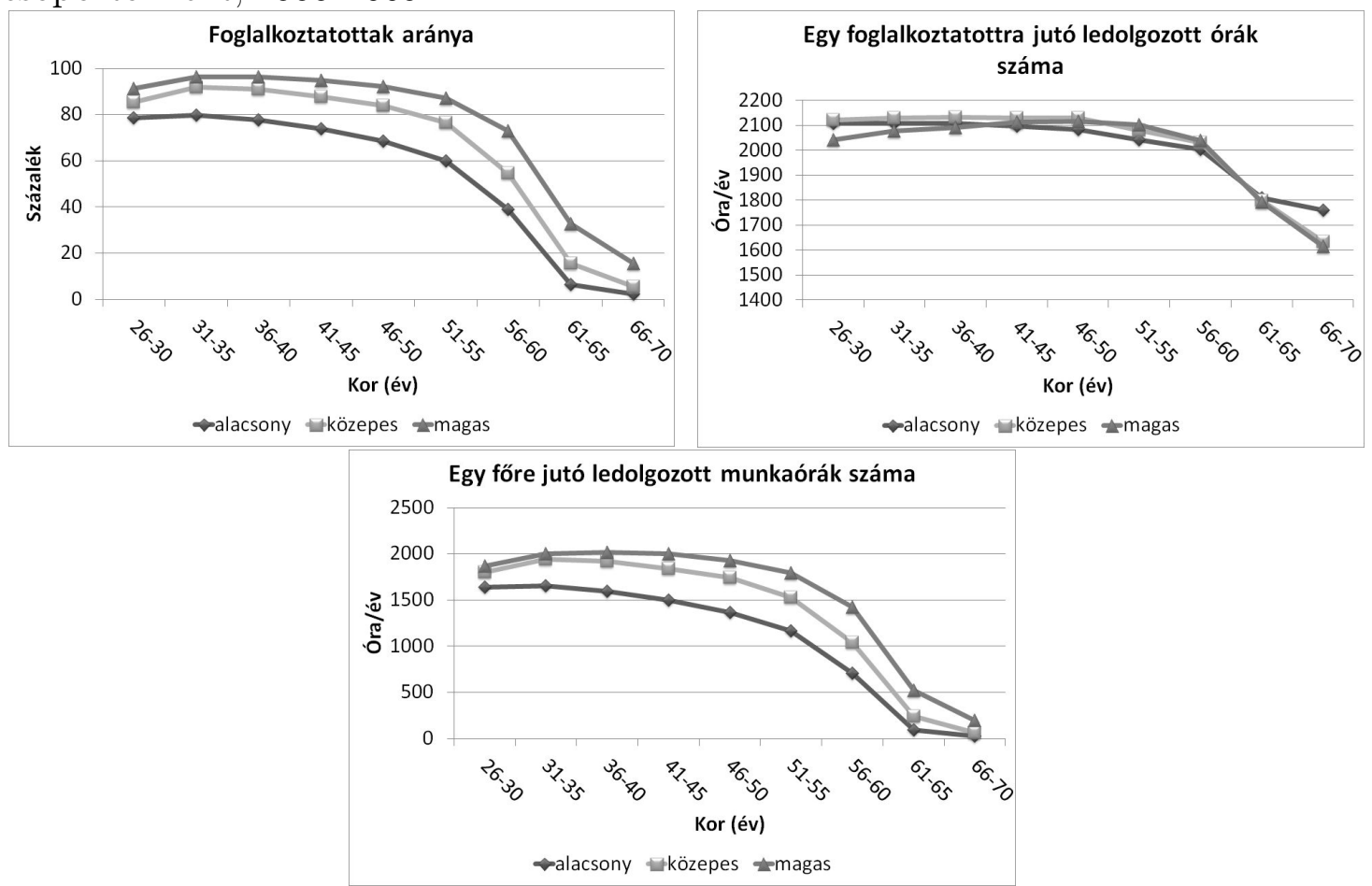

Forrás: saját számítás a KSH munkaerô-felmérése alapján

Kátay szerk. [2009] bemutatta, hogy a magyar aktivitási ráta lemaradását az Európai Unió 15 fejlett országához képest a szülóképes korú nók, a fiatalok és az idősek alacsony aktivitási rátája mellett az alacsonyan képzettek alacsony aktivitásával magyarázható. Emiatt megvizsgáltuk, hogy a munkaórák korprofiljai mutatnak-e lényeges eltérést három - alacsony (maximum 8 általános iskolával vagy szakmunkás), közepes (középfokú: szakközépiskolai, gimnáziumi és a technikusi), illetve magas (felsőfokú: főiskolai, egyetemi) végzettségú - képzettségi csoport tag- 
jai között. A 3.3. ábrán látható, hogy valamennyi korosztályban a képzettebb csoportok évente átlagosan több órát dolgoztak, mint a kevésbé képzettek.

Az eltérések azonban életkor szerint jelentôs különbségeket mutatnak (Függelék, 8.2. ábra). Az alacsony képzettségúekhez képest az eltérések kezdetben csak lassú ütemben nônek, ahogy az idôsebb kor felé haladunk: 26-30 éves korban a közepes képzettségúek 10, a magas képzettségúek 14 százalékkal dolgoztak többet, az 51-55 éves korosztályban már 31 illetve 54 százalékkal. Ezt követően azonban a képzettségi különbségek gyorsan emelkedtek: az 56-60 éves korosztályban a közepes képzettségúek munkaórái már 48, a felsőfokú végzettségúek 102 százalékkal haladták meg az alacsony képzettségúekét, a 61-65 éves korosztályban pedig már 159 és 465 százalék volt a különbség. Az eltérést most sem a foglalkoztatottak által ledolgozott órák okozzák, hanem a foglalkoztatottsági arányok különbségei. Sơt, a legidôsebbek között az intenzív határon az alacsony képzettségúek dolgoztak minimálisan többet.

\subsection{Magyar nyugdíjrendszer és munkakínálat}

\subsubsection{Az öregségi és rokkantsági nyugdíjrendszer munkakí- nálatra ható elemei 1999 és 2009 között}

A következókben a társadalombiztosítás öregségi és rokkantsági nyugdíjrendszereinek azon jellemzőit ismertetjük, amelyek 1999 és 2009 között a férfiak munkakínálatát befolyásolhatták.

1997-től 2010-ig Magyarországon három pilléres öregségi nyugdijrendszer múködött (kötelezô társadalombiztosítás, kötelezô magánnyugdíj és önkéntes nyugdíj), melyekból fontossága miatt a továbbiakban az elsố pillér témánk szempontjából érdekes jellemzőinek ismertetésére szorítkozunk ${ }^{6}$

\footnotetext{
${ }^{6}$ A magyar nyugdíjrendszer pontos jellemzőit, fejlődéstörténetét leírja például Augusztinovics és szerzôtársai [2002], Orbán, Palotai [2006], Simonovits [2009a], Holtzer szerk. [2010] és
} 
3. fejezet: Parametrikus nyugdíjreformok és életciklus-munkakínálat

A legközvetlenebb módon a munkapiaci aktivitásra az általános nyugdíjkorhatár gyakorolhat befolyást. Magyarországon teljes öregségi nyugdíjra az 1997-es reformot követôen a férfiak 62 éves korukban lettek jogosultak. A korhatár 1997-et követően 60 éves korról 62 évre emelkedett rövid átmenetet követően 7 A jogosultság további feltétele a 20 év szolgálati idő megszerzése. 8 Lehetőség volt azonban előrehozott öregségi nyugdíj igénylésére is, amely a férfiaknál 60 éves korban vált lehetôvé. Az elôrehozott nyugdíj csökkentés nélkül volt igényelhető, amennyiben az illető 38 év szolgálati idôvel rendelkezett!9 Ennél kevesebb - minimum 33, késóbb 37 - szolgálati év mellett is járt ugyan az előrehozott nyugdíj, de ebben az esetben a teljes nyugdíjhoz képest a hiányzó kor és a hiányzó szolgálati évek függvényében csökkent a nyugdíj összege. Az elörehozott öregségi nyugdíjkorhatárhoz képest még korábban is volt lehetôség a munkáltatóval kötött megállapodás esetén korengedményes nyugdíj igénylésére, hosszabb munkanélküliség esetén előnyugdíjra (késóbb nyugdíj elótti munkanélküli segélyre), illetve a szervezet fokozott igénybevételével járó vagy az egészségre különösen ártalmas munkakör esetén korkedvezményes nyugdíjra. 10

A másik tényezô, amely a munkakínálatot befolyásolhatja az, hogy a munkapiacon eltöltött évek milyen mértékben járulnak hozzá a későbbi nyugdíj összegéhez. Egy korábbi munkajövedelmektôl teljesen független nyugdíj például kizárólag azon keresztül hathat a munkakínálatra, hogy az életpálya-jövedelmek jelenértékét növeli (vagyonhatás). Egy olyan nyugdíjrendszer viszont, amelyben a nyugdíj teljesítményfüggő, tovább ösztönözheti a munkavállalást. Fontos tehát, hogy milyen erôs a kapcsolat az életpálya keresetei és a nyugdíjak között. A törvényi korhatár elôtti/utáni nyugdíjbavonulás választása is attól függ, hogy mennyire "kifizetôdô"

Simonovits [2011]. Kovács [2008] összehasonlítja a magyar nyugdíjrendszer paramétereit más országokéval.

${ }^{7}$ A törvényi nyugdíjkorhatár további emelésérôl a kormány csak 2009-ben döntött.

${ }^{8} \mathrm{~A}$ minimális szolgálati idôvel nem rendelkezô öregségi résznyugdíjhoz 15 szolgálati év is elegendố volt. A szolgálati évek nem egyeztek meg a munkában töltött évekkel, például a rokkantsági nyugdíj folyósításának ideje is hozzájuk adódott.

${ }^{9} 2009$-tốl a csökkentés nélküli elórehozott nyugdíjhoz már 40 szolgálati év volt szükséges.

${ }^{10} \mathrm{~A}$ fegyveres erôk, rendvédelmi szervek, valamint a polgári nemzetbiztonsági szolgálatok hivatalos állományának nyugdíjáról külön törvény rendelkezett, amely az elóbb felsorolt kedvezményekhez képest még korábbi nyugdíjazást is lehetôvé tett. 
az egyik vagy másik opció választása, vagyis számít, hogy mennyire bünteti/díjazza biztosításmatematikailag tisztességes módon a nyugdíjrendszer a hiányzó/további éveket.

A megállapított nyugdíj Magyarországon a nyugdíjkiszámításban figyelembe vett életpálya-átlagkeresetnek és egy szolgálati évektől függő helyettesítési rátának a szorzata. A helyettesítési ráta 20 szolgálati év esetén a havi nettó átlagkeresetek 53, 40 szolgálati év esetén 80 százalékát biztosította. A ráta növekedése ugyanakkor nem egyenletes: az elsô 25 szolgálati évben évente 2, az ezt követő 10 szolgálati évben évente 1, végül az ezt követő 5 évben 1,5 százalékponttal emelkedik. A helyettesítési ráta 80 százalék fölé is emelkedhetett: minden további szolgálati év a rátát további 1,5 (2009-tól 2) százalékkal növelte.11 Az ONYF Kelen adatbázisa alapján az átlagos helyettesítési ráta az öregségi nyugdíjasoknál 1999 és 2009 között 75-ról körülbelül 72,5 százalékra csökkent.

A nyugdíj összegének a meghatározásánál figyelembe vett másik tényezôt a korábbi havi nettó átlagkereset nettó bérnövekedéssel valorizált átlagából és egy degresszivitási tényezóból lehetett nyerni. Az átlagkeresetekbe minden, 1988 utáni kereset beleszámít, ezért a késóbb született korosztályok számára a nyugdíjat az életpályájuk egyre nagyobb részének keresetei alapján számítják. A változás egy emelkedő kereseti profil mellett a kezdő nyugdíjak értékét csökkenti. A keresetek és a nyugdíjak közötti kapcsolat szorosságát a degresszivitás gyengíti, de degresszivitási sávok értékhatárainak a gyors növekedése ezt a kapcsolatot az idôszak során fokozatosan erôsebbé tette. A legmagasabb keresetúek körében csökkentheti a keresetek és a nyugdíj közötti kapcsolat szorosságát, hogy a vizsgált idôszakban a nettó fizetés kiszámításakor kizárólag a járulékplafonig terjedô bruttó fizetést kellett figyelembe venni. Az alacsony keresetú, teljes öregségi nyugdíjra jogosultak esetén pedig a kapcsolatot a nyugdíjminimum is gyengítheti.

Az előrehozott öregségi nyugdíj mérlegelésében fontos, hogy a törvényes korhatárig, illetve a szükséges szolgálati idôbôl hiányzó éveket a nyugdíj megállapításánál milyen mértékben bünteti a törvény. Az időszak során uralkodó szabályok szerint a

\footnotetext{
${ }^{11} \mathrm{Az}$ átlagos helyettesítési ráta értékét és az aktív gazdasági szereplők viselkedését megváltoztathatta a 13 . havi nyugdíj bevezetése.
} 
3. fejezet: Parametrikus nyugdíjreformok és életciklus-munkakínálat

csökkentés mértéke a tövényes korhatár betöltéséhez szükséges hónapok számának és az előrehozott teljes nyugdíjhoz szükséges szolgálati évek számának az egytizede. 62 éves törvényi korhatár mellett 60 éves korban történő nyugdíjba vonulás és 33 szolgálati év esetén például ez $24 \times 0,5=12$ százalékos csökkentést jelentett. A törvényi nyugdíjkorhatár utáni munkát ösztönözhette, hogy a nyugdíjba vonulás elhalasztása esetén az öregségi nyugdíj értéke 30 naponként 0,3 , a késóbbi változások után 0,4 ill. 0,5 százalékkal nôtt. Az így kiszámított nyugdíj - ellentétben a törvényi korhatár idején igényelttel - meghaladhatta a korábbi nettó keresetek átlagát.

A munkakínálatot nem csupán a kezdő öregségi nyugdíj, hanem a várható nyugdíjak jelenértéke, így a nyugdíjak indexálása is befolyásolja. A vizsgált idôszakra a bérindexálást a felerészt árakat, felerészt béreket követő követő svájci indexálás váltotta fel.

Rokkantsági nyugdíjra a vizsgált időszakban életkortól függetlenül az volt jogosult, akinek a munkaképesség-romlása, késóbb egészségkárosodása meghaladt egy bizonyos mértéket, és nem dolgozott vagy keresete jelentősen visszaesett a megrokkanás óta. A teljes rokkantsági nyugdíjhoz életkortól függóen egy minimális szolgálati idő is szükséges volt. Az 1998. előtti rendszerrel szemben a rokkantsági státusz nem szól egy életre, hanem idôközönként felülvizsgálják.

A rokkantsági nyugdíjak értékének a kiszámítása alapvetően megegyezik az öregségiével, leszámítva, hogy itt korcsoportonként eltérô szolgálatiidô-skálát kell használni, illetve a nyugdíj értéke függ a rokkantság fokától is. A legmagasabb, 25 éves szolgálati idő esetén a legenyhébb rokkantsági kategóriába esők (rokkant, de nem teljesen munkaképtelen) korábbi fizetésük átlagának 63 százalékát kapták, de már 15 év szolgálati idô mellett is 58-47,5 százalékos volt a helyettesítési ráta, a nyugdíjazott korától függóen. A nyugdíj értékének van rokkantsági kategóriánként eltérô minimális összege. Egy további szigorítás eredményeként pedig a rokkantsági nyugdíj mellett keresett jövedelem a megrokkanás előtti keresetek kisebb részét tehette ki, mint korábban. Az ONYF Kelen adatbázisa alapján a rokkantsági nyug- 
díjasok átlagos helyettesítési rátája 69,8-ról 66,2 százalékra csökkent 1999 és 2009 között 12

\subsubsection{Nyugdíjasok és foglalkoztatottság 1999 és 2009 között}

A KSH munkaerô-felmérése segítségével, hogy a rokkantsági és az öregségi nyugdíjban részesülő, illetve a rokkantsági és az öregségi nyugdíjba vonuló férfiaknak milyen volt az életkor szerinti eloszlása 1999 és 2009 között.

3.4. ábra. Nyugdíjas és foglalkoztatott férfiak aránya korosztályonként 2004-ben.

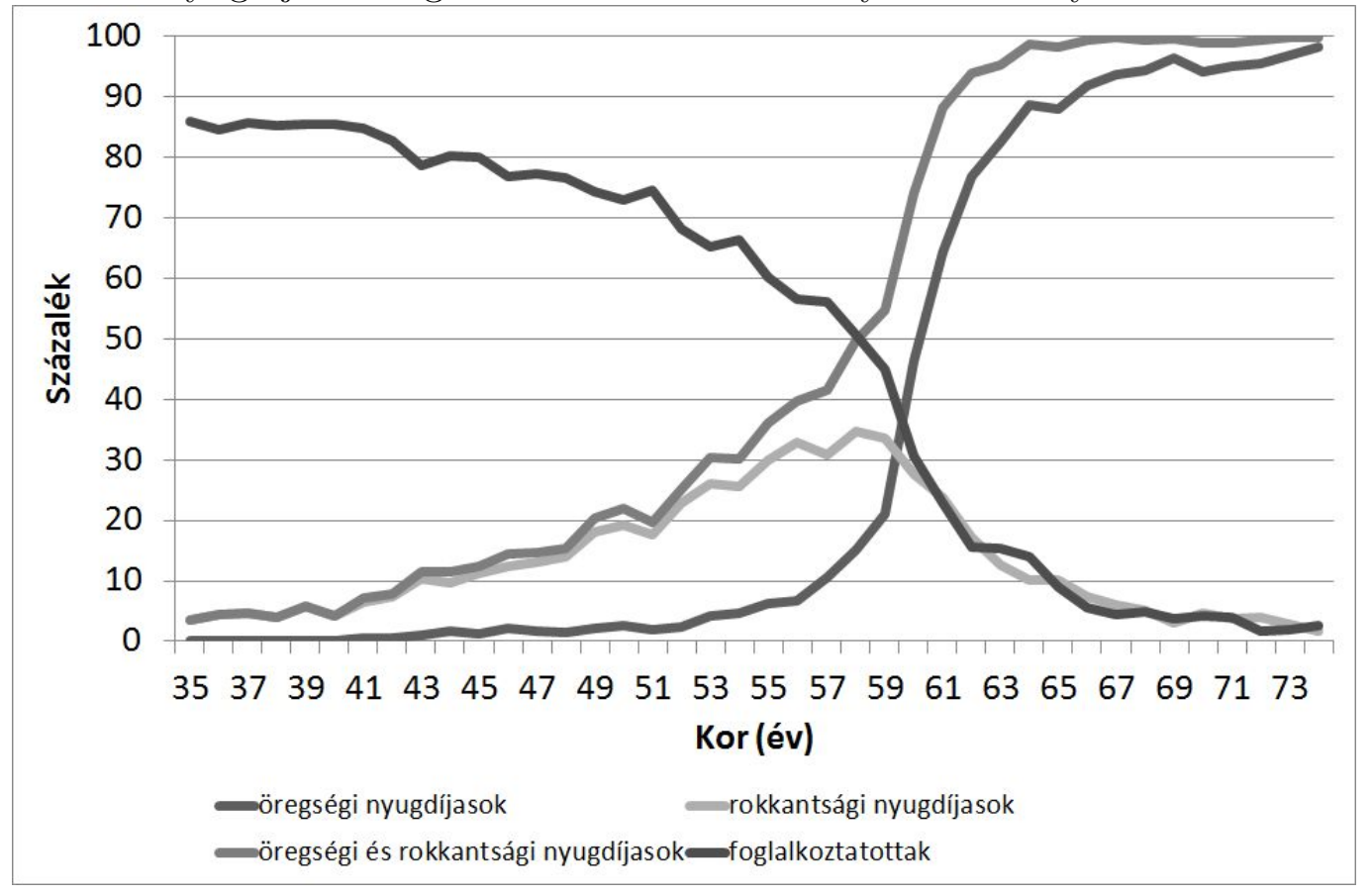

Forrás: saját számítás a KSH munkaerô-felmérése alapján

Az adatokból kirajzolódó tendencia, hogy az idôsebb korcsoportok esetében a foglalkoztatottak aránya és az öregségi nyugdíjban részesülók aránya egymással ellentétesen mozog. A kiemelt 2004. évben az öregségi nyugdíjas férfiak aránya 56

\footnotetext{
${ }^{12} \mathrm{~A}$ fejezetben szereplő modell nem tartalmazza a rokkantsági nyugdíjba vonulás lehetôségét, elsôsorban az ehhez szükséges egészségi állapotra vonatkozó adatok hiánya miatt.
} 
3. fejezet: Parametrikus nyugdíjreformok és életciklus-munkakínálat

éves korban még nem éri el a 7 százalékot, a 61 éveseknek azonban már 64, a 62 éveseknek 77 százalék (3.4 ábra). A két profil ellentétes lefutása természetesen oksági viszonyként még nem értelmezhető. Lehetséges, hogy az egészség, a munkaképesség romlása nyugdíjrendszer hiányában is csökkentené a munkapiaci aktivitást, és a nyugdíjrendszer valóban csak pótolja az így elveszített munkajövedelmek egy bizonyos hányadát. Az is lehetséges azonban, ahogy erre a mikroökonómiai adatokon nyugvó empirikus irodalom alapján következtethetünk, hogy a nyugdíjrendszer maga is ösztönzte a munkapiac elhagyását, illetve maga is befolyásolta idős korban a munkakínálat mértékét. Ez még akkor is igaz lehet, ha a nyugdíjrendszer a vizsgált idôszakban megengedte nyugdíj mellett a foglalkoztatást, és a 60-65 éves nyugdíjasoknak mintegy 5-15 százaléka foglalkoztatott maradt.

A másik jelenség, ami az állományi adatokból megfigyelhető, hogy a foglalkoztatottak arányának csökkenése hamarabb következik be, mint az öregségi nyugdíjasok arányának megemelkedése. A rokkantsági nyugdíjban részesülók aránya viszont éppen ebben a korban emelkedik. A kiemelt 2004-es évben a rokkantnyugdíjasok aránya az 56-58 éves korosztályon belül a legmagasabb (33-34 százalék), de már a 49 éves férfiak között is 18 százalék. A rokkantsági nyugdíjak ismertetésénél láttuk, hogy az alrendszer már 15 év szolgálati év után is mintegy 50 százalékos helyettesítést biztosít. A foglalkoztatottak arányának csökkenéséhez a rokkantsági nyugdíjrendszer viszonylag kedvezô helyettesítési rátája is hozzájárulhatott a jogosultság ellenőrzésének a "lazasága" mellett.

A két nyugdíjrendszer együttes hatása így már jóval a törvényes nyugdíjkorhatár előtt igen jelentôs: 55 éves korára a férfiaknak már 36 százaléka részesült az ellátások egyikében 2004-ben.

Az 1999 és 2009 közötti időbeli alakulást vizsgálva (a Függelék 8.3. ábrája) azt is megállapíthatjuk, hogy az öregségi nyugdíjasok aránya 56 és 63 éves kor között számottevôen csökkent (a 60 évesek között az öregségi nyugdíjasok aránya például 61 százalékról 48 százalékra csökkent az időszak végére), csakúgy, mint a rokkantnyugdíjasok aránya az összes 60 év alatti korosztályban. Az arányok csökkenését a korhatáremelés végigfutása, illetve a két rendszer jogosultsági feltételeinek a szigorítása egyaránt indokolhatja. 
3.5. ábra. Rokkantsági és öregségi nyugdíjba vonuló férfiak aránya korosztályonként
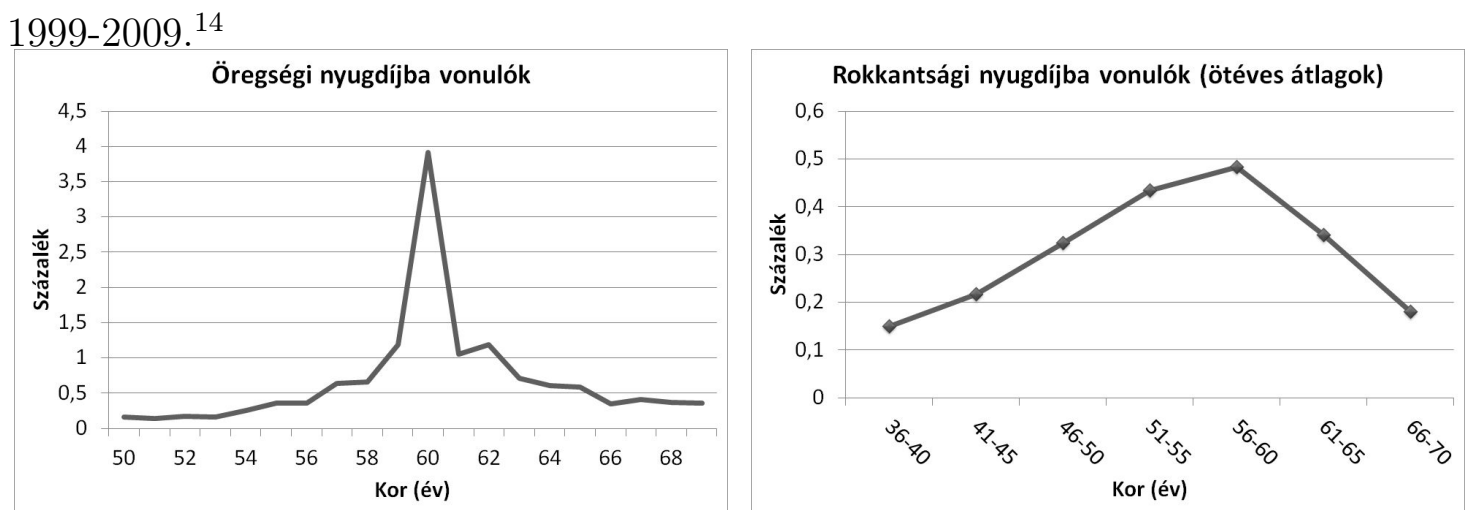

Forrás: saját számítás a KSH munkaerô-felmérése alapján

Az állományi adatokhoz képest informatívabbak lehetnek a KSH munkaerófelméréséból nyert áramlás jellegú mutatók (3.5. ábra), vagyis hogy milyen az öregségi és rokkantsági nyugdíjba vonulók kor szerinti eloszlása.15 A felmérésekból megállapítható, hogy a legnagyobb gyakorisággal 60 éves korukban mentek öregségi nyugdíjba a férfiak. A rokkantsági nyugdíjba vonulás valószínúsége 57-58 éves korban veszi fel maximumát, efölött pedig valószínüsége csökken az öregségi rendszer elérhetősége miatt.

Az adatok szerint az öregégségi nyugdíjasok esetében jellemzô tendencia, hogy az idôszak végére az öregségi nyugdíjba vonulók aránya egyre inkább a 60 éves kor körül koncentrálódott, minden ettől eltérô életkorokban a nyugdíjba vonulás valószínúsége csökkent. Megfigyelhetô az is, hogy 2009-re szinte minden korosztályban alacsonyabb volt a rokkantsági nyugdíjba vonulás valószínúsége, mint az 1999-es évben (a Függelék 8.4. ábrája). Az újonnan nyugdíjba vonulók átlagos életkorát a munkaerő-felmérésból nem lehet megbízhatóan megállapítani, ezért ennek meghatározásánál az ONYF Kelen adatbázisára hagyatkoztunk. Ezek szerint az új öregségi nyugdíjasok átlagos életkora 59,5 év körüli értéket vett fel, kevés változé-

\footnotetext{
${ }^{14} \mathrm{~A}$ rokkantsági nyugdíjba vonulók adatainál ötéves átlagokat jelenítettünk meg.

${ }^{15}$ Öregségi nyugdíjba vonulónak azokat nyilvánítottuk, aki az elôző negyedében még nem kaptak öregségi nyugdíjat, de a következô negyedévben már igen. A rokkantsági nyugdíjba vonulók számát hasonló elvek alapján határoztuk meg.
} 
konyságot mutatva az időszak során, míg a rokkantsági nyugdíjba vonuló férfiak átlagos életkora 46,86 évrôl 50,91 évre nôtt 2009-re.

3.6. ábra. Rokkantsági és öregségi nyugdíjas férfiak aránya korosztályonként, képzettségi csoportonként 1999-2009.
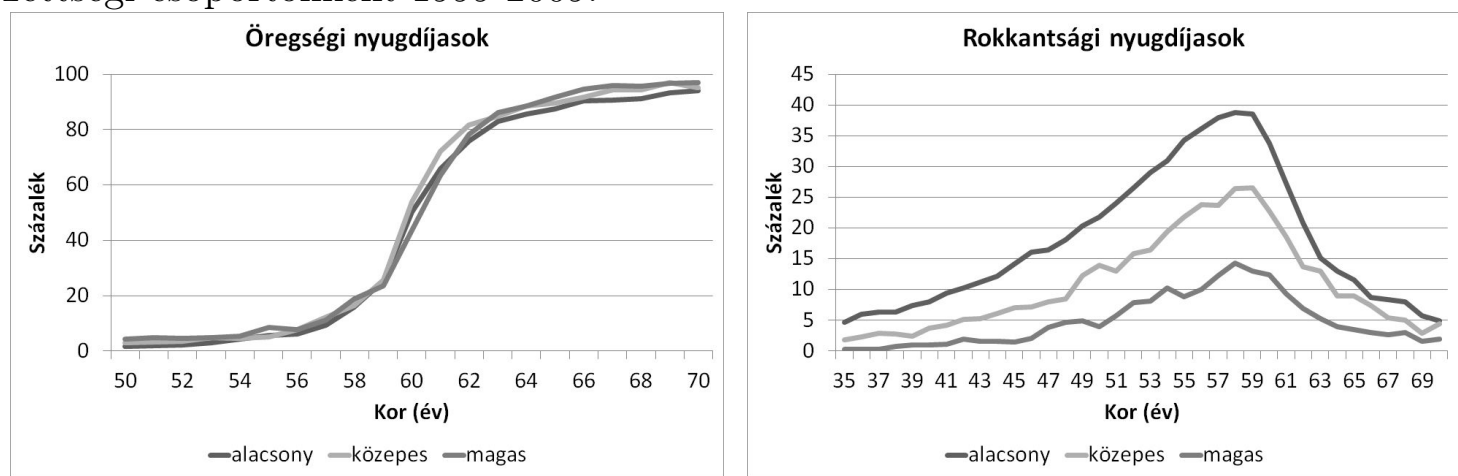

Forrás: saját számitás a KSH munkaeró-felmérése alapján

3.7. ábra. Rokkantsági és öregségi nyugdíjba vonuló férfiak aránya korosztályonként, képzettségi csoportonként 1999-2009.
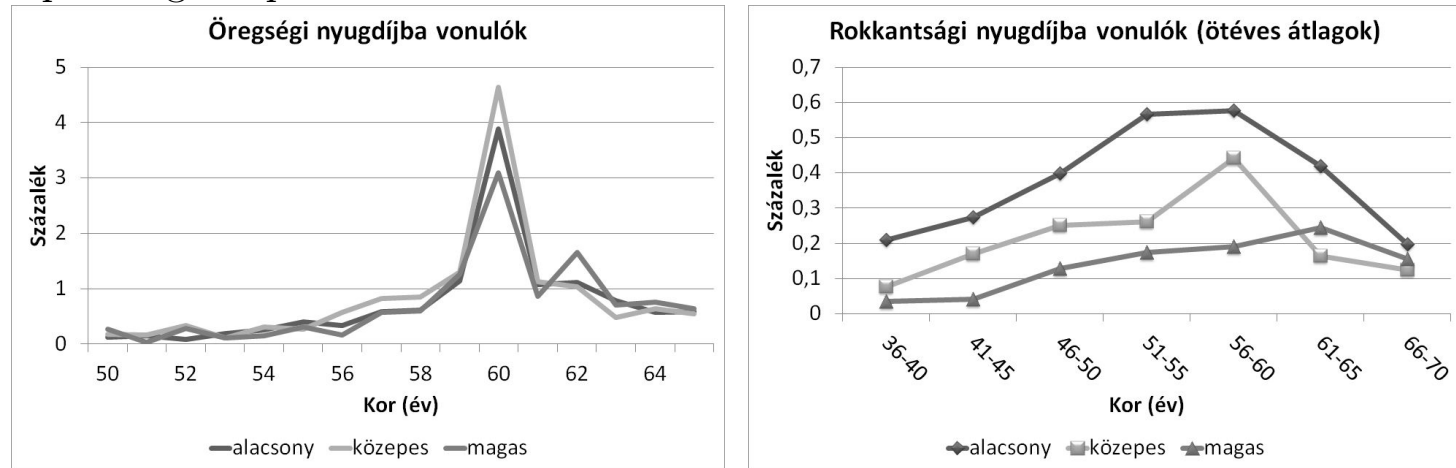

Forrás: saját számitás a KSH munkaerô-felmérése alapján

Óvatos megállípításokkal kiegészíthetjük a leírtakat, ha képzettség szerinti bontásban megismételjük az elóbbi vizsgálatokat. Az öregségi nyugdíjasok állományi adatai alapján a kritikus 60 éves kor környékén a magas képzettségúek a másik két csoport tagjainál kisebb része volt öregségi nyugdíjban (3.6). Az öregségi nyugdíjba vonulók adatai alapján azt emelhetjük ki, hogy a magas képzettségúek kisebb aránya vonul nyugdíjba 60 éves korában, és náluk egy kisebb "csúcs" 62 éves korban is megfigyelhetô. A rokkantsági nyugdíjasok esetében az állományi és a flow 
adatokból egyaránt az a következtetés vonható le, hogy a nyugdíjazás lehetôségével szinte minden életkorban az alacsonyabb képzettségúek éltek jobban.

\subsection{Az életciklus-munkakínálat modellje}

A következőkben felvázoljuk életciklus-munkakínálati modellünk alapjait. Az egyegy képzettségi csoportot reprezentáló fogyasztó három életszakaszban maximalizálja az életpálya-hasznosságát, melynek során fogyasztási-megtakarítási és munkakínálati döntést hoz, majd egy mindenki számára egységes nyugdíjkorhatárt követően felhagy a munkával, és korábbi teljesítménye alapján nyugdíjat kap. Döntései során figyelembe veszi halandósági kockázatait, valamint azt is, hogy késóbbi nyugdíjához nettó munkajövedelmeivel hozzájárul. Egységnyi munkára jutó reálbérét egy életkortól és képzettségtôl függô exogén termelékenységi profil befolyásolja. Nyugdíjának kezdőértéke a "nyugdíjfelhalmozó" évek nettó jövedelmeinek konstans hányada, késôbbi nyugdíja pedig felerészt követi az átlagos termelékenységnövekedést.

A munkakínálati (és fogyasztási) döntést hozó egyéneknek a vizsgált jelenség szempontjából releváns életpályáját három nagy szakaszra bontottuk. A szakaszokon belüli periódusok ötéves időszakoknak feleltethetók meg. A három szakasz a következő.

1. Fiatalok: fogyasztási és munkakínálati döntéseket hoznak, a kereseteknek azonban nincs hatása a késóbbi nyugdíjakra, a nyugdíjak kiszámításának alapjául szolgáló életpálya-átlagkeresetbe nem számítanak be. A fiatal periódusok száma $J_{1}$, azaz a fiatalkori idôszakban $1 \leq j \leq J_{1}$ 트

\footnotetext{
${ }^{16} \mathrm{Az} 1999$ és 2009 között megfigyelt munkavállalók keresetei minden évben hozzájárultak késóbbi nyugdíjukhoz, ezért az alapváltozatban ezen időszakok számát nullának vettük. Az elsô életszakasz elkülönítését mégis fontosnak találtuk, hiszen a kezdô nyugdíj kiszámításának alapjául szolgáló nettó életpálya-kereseteket csak 1988-tól veszik figyelembe, ezért a késóbb született korosztályok nyugdíját több év nettó életpálya-keresetének átlagaként számolják. Ezen válto-
} 
3. fejezet: Parametrikus nyugdíjreformok és életciklus-munkakínálat

2. Középkorúak: fogyasztási és munkakínálati döntéseket hoznak, azonban az utóbbi döntéseik közvetlenül kihatnak a nyugdíjas évekbeli jövedelmeikre. Feltesszük, hogy a nyugdíjak kezdőértékét ezen időszak nettó béreinek az átlaga alapján határozzák meg, egy exogén helyettesítési ráta szerint. A középkori idôszakban $J_{1}+1 \leq j \leq J_{1}+J_{2}$.

3. Nyugdíjasok: ezen idôszak alatt nyugdíjat kapnak (nyugdíjindexálás), munkakínálati döntést nem hoznak, csak fogyasztási döntést. $J_{1}+J_{2}+1 \leq j \leq$ $J_{1}+J_{2}+J_{3}=J$.

Külön indexszel nem jelöljük, de az egyéneknek három típusát, alacsony, közepes és magas végzettségúeket különböztetünk meg. A három típus jellemzói között az egyedüli különbséget a termelékenységi profiljaik paraméterei jelentik, melyek eltérô értékeit a modell kalibrálásánál tüntetjük fel.

\subsubsection{A háztartások döntési problémája}

\section{Az életpálya hasznossága}

A modellben csak a 26 év fölötti férfiak jelennek meg, akik maximálisan 100 évig a modellben tehát 15 idôszakig - élnek, a maximalizálandó életpálya-hasznossági függvényük az alábbi formát ölti:

$$
V=\sum_{j=1}^{J_{1}+J_{2}+J_{3}} \beta^{j-1} \psi_{j} u\left(c_{j}, l_{j}\right),
$$

ahol $\psi_{j}$ a túlélési valószínúség, $0<\beta<1$ a diszkont tényezô. $u(.,$.$) a pillanat-$ nyi hasznossági függvény, amely a fogyasztás $\left(c_{j}\right)$ és az 1-re normált munka $\left(l_{j}\right)$ additíven szeparábilis függvénye:

$$
u\left(c_{j}, l_{j}\right)=\frac{c_{j}^{1-\sigma}}{1-\sigma}-\gamma \frac{l_{j}^{1+\xi}}{1+\xi},
$$

zás munkakínálatra gyakorolt hatását a szimulációk során úgy tudtuk ,inverz” módon figyelembe venni, ha az elsó életszakasz periódusainak a számát nulláról egyre emeltük. 
${ }^{17}$ hhol $\xi>0$ a munkakínálat Frisch-féle rugalmasságának reciproka, $\gamma>0$ mutatja a munka súlyát a döntéshozó preferenciáin belül, $\sigma$ pedig az intertemporális helyettesítési rugalmasság reciproka, melyre igaz, hogy $\sigma>0, \sigma \neq 1 .{ }^{18}$

\section{A költségvetési korlát}

Az aktívak (fiatalok és középkorúak) költségvetési korlátja Egy aktív, $j$ éves munkavállaló költségvetési korlátja

$$
a_{j+1}+c_{j}+\operatorname{Tax}_{j}=\left(1+r_{j}\right) a_{j}+W_{j} \quad h a \quad 1<j \leq J_{1}+J_{2},
$$

azaz a munkabérét $\left(W_{j}\right)$ és felhalmozott vagyonát $\left(a_{j}\right)$, illetve ennek kamatát $\left(r_{j}\right)$ vagyon felhalmozására $\left(a_{j+1}\right)$, fogyasztásra $\left(c_{j}\right)$ és a nettó adók $\left(\operatorname{Tax}_{j}\right)$ megfizetésére fordítja. A nettó adók összetevơi a fogyasztási adó $\left(\tau_{c} c_{j}\right)$, a tôkejövedelem-adó $\left.\left(\tau_{k} r_{j} a_{j}\right)\right)$, a munkajövedelem-adó $\left(\tau_{l} W_{j}\right)$ és a nyugdíjjárulék $\left(\tau_{b} W_{j}\right)$ :

$$
\operatorname{Tax}_{j}=\tau_{c} c_{j}+\tau_{k} r_{j} a_{j}+\left(\tau_{l}+\tau_{b}\right) W_{j}
$$

A nyugdíjasok költségvetési korlátja Egy $j$ éves nyugdíjas költségvetési korlátja

$$
a_{j+1}+c_{j}+\operatorname{Tax}_{j}=\left(1+r_{j}\right) a_{j}+b_{j} \quad h a \quad J_{1}+J_{2}<j \leq J,
$$

azaz nyugdíjasként nyugdíját $\left(b_{j}\right)$ felhalmozott vagyonát $\left(a_{j}\right)$, illetve ennek kamatát $\left(r_{j}\right)$ vagyon felhalmozására $\left(a_{j+1}\right)$, fogyasztásra $\left(c_{j}\right)$ és a nettó adókra $\left(\operatorname{Tax}_{j}\right)$ fordítja. Nyugdíjas korában nem dolgozik $\left(l_{j}=0\right)$, és az adófizetési kötelezettségei is ennek megfelelően csökkennek, ezért csak fogyasztási adót és kamatadót kell fizetnie.

\footnotetext{
${ }^{17} \mathrm{~A}$ hasznossági függvény nem konzisztens a neoklasszikus növekedési modellekkel, ahol az állandósult állapot létezésének feltétele a

$$
u(c, l)=\left\{\begin{array}{c}
\frac{c^{1-\sigma} v(l)}{1-\sigma}, \text { ha } \sigma \neq 1 \\
\ln c-v(l), \text { ha } \sigma=1
\end{array}\right\}
$$

függvényforma. Véges élettartam esetén, egy életciklus modellben azonban ez a korlátozás nem érvényes.

${ }^{18} \sigma \rightarrow 1$ esetben a pillanatnyi hasznosság a fogyasztásban logaritmikus.
} 
A háztartásnak nincs induló vagyona $\left(a_{1}=0\right)$, és nem is tervezi, hogy örökséget hagyjon hátra maximális élettartamának a végére $\left(a_{J+1}=0\right)$.

Reálbér A $j$ éves munkavállaló összes bérét $\left(W_{j}\right)$ a hatékonysági egységre jutó reálbér $(w)$, a termelékenység $\left(e_{j}\right)$ és a ledolgozott órák $\left(l_{j}\right)$ szorzataként kapjuk meg:

$$
W_{j}=w e_{j} l_{j}
$$

Az életpálya során a munkavállalók termelékenysége változik $\left(e_{j}\right)$. Ez az életpályakeresetek ívétól (az ív az életkor kvadratikus függvénye, a függvényt az $a^{0}, a^{1}$, $a^{2}$ paraméterek jellemzik) és a munkakiterjesztô technikai haladástól $\left(A_{j}\right)$ függ:

$$
e_{j}=A_{j} e^{a^{0}+a^{1} j+a^{2} j^{2}}
$$

A technikai haladás növekedési üteme $\lambda$ :

$$
A_{j}=(1+\lambda) A_{j-1},
$$

ahol $A_{1}=1$

A nyugdíjak kiszámításának a módja Az induló nyugdíj értékét $\left(b_{J_{1}+J_{2}+1}\right)$ két tényezố szorzata adja $\sqrt[19]{19}$ A két tényezố a nyugdíjbavonulást megelôző $J_{2}$ periódus nettó munkajövedelmének átlaga $\left(\bar{W}_{J_{1}+1}^{J_{2}}\right)$ és a pótlási arány $(\alpha)$ :

$$
b_{J_{1}+J_{2}+1}=\alpha \bar{W}_{J_{1}+1}^{J_{2}} .
$$

A korábbi $J_{2}$ periódus nettó bérének átlaga:

$$
\bar{W}_{J_{1}+1}^{J_{2}}=\frac{1}{J_{2}} \sum_{j=J_{1}+1}^{J_{1}+J_{2}}\left(1-\tau_{l}-\tau_{b}\right) W_{j} .
$$

Ahhoz, hogy a gazdasági szereplók munkakínálati döntésük során figyelembe tudják venni annak a késóbbi kezdố nyugdíjukra gyakorolt jótékony hatását, az

\footnotetext{
${ }^{19}$ A megoldhatóság érdekében a modellbéli nyugdíjrendszer roppant egyszerű, például nem tartalmaz szolgálati évektôl függó helyettesítési rátát.
} 
összefüggést egy "nyugdíjfelhalmozási egyenletté" alakítottuk. Az összefüggés azt mutatja meg, hogy az egyének idôarányosan mennyivel gyarapítják késóbbi kezdô nyugdíjuk értékét az aktív életszakaszukban $\left(J_{1}+1 \leq j \leq J_{1}+J_{2}\right)$ :

$$
b_{j+1}=b_{j}+\frac{\alpha\left(1-\tau_{l}-\tau_{b}\right) W_{j}}{J_{2}} .
$$

Általános egyensúlyi feltétel és együttélő korosztályok híján a nyugdíjak indexálásához használt bérnövekedési ütem helyettesíthető az exogén technikai haladással. Általánosságban tehát a nyugdíjindexálás formulája $\left(J_{1}+J_{2}+1 \leq j \leq J_{1}+J_{2}+J_{3}\right)$ :

$$
b_{J}=b_{J_{1}+J_{2}+1}(1+\lambda)^{\left(j-J_{1}-J_{2}-1\right)(1-\nu)} J_{1}+J_{2}+1<j \leq J
$$

ahol az inflációt követik a nyugdíjak, ha $\nu=1$, reálbérek növekedését, ha $\nu=0$, és svájci indexálást használnak, ha $\nu=0,5$. A nyugdíjfelhalmozás elôtt $(1 \leq j \leq$ $\left.J_{1}+1\right)$ persze $b_{j}=0$.

\subsubsection{A háztartás fogyasztási és munkakínálati döntése}

A modell megoldását részletesen az F.2. Függelékben ismertetjük. ${ }^{20}$ Itt megvizsgáljuk azt, hogy milyen tényezók hatnak a modellben a fiatalok és középkorúak munkakínálatára. Fiatal korban $\left(1 \leq j \leq J_{1}\right)$, amikor a nettó bérek nem befolyásolják a késóbbi nyugdíj értékét, a döntést egy hagyományos munkakínálati összefüggés vezérli.

$$
l_{j}=\left(\frac{1-\tau_{l}-\tau_{b}}{\left(1+\tau_{c}\right) \gamma} c_{j}^{-\sigma} w e_{j}\right)^{1 / \xi}
$$

A szereplők ekkor a magasabb termelékenységgel és nettó bérrel, illetve alacsonyabb fogyasztással (és magasabb határhaszonnal) jellemezhető időszakok felé csoportosítják át a munkájukat. A fogyasztás pályáját az alábbi kifejezés határozza meg:

$$
c_{j}=\left\{\left[\beta\left(1+r_{\tau}\right)\right]^{j-1} \frac{\psi_{j}}{\psi_{1}}\right\}^{1 / \sigma} c_{1},
$$

\footnotetext{
${ }^{20} \mathrm{~A} 3$ és a 4 fejezetben a háztartások feladata között kis eltérések vannak. A Függelékben egy olyan feladatot oldunk meg, amely speciális esetként tartalmazza mindkét fejezet problémáját. A jelen fejezethez tartozó megoldás konstans fogyasztási adókulcs feltételezésével $\left(\tau_{c}\right)$, az időre vonatkozó indexek elhagyásával, $g=G=1, B e q=z=0$ behelyettesítésekkel adódik.
} 
3. fejezet: Parametrikus nyugdíjreformok és életciklus-munkakínálat

ahol az adózás utáni kamatláb értékére a $r_{\tau}=\left(1-\tau_{k}\right) r$ jelölést vezettük be.

A fogyasztás időbeli pályáját a türelmetlenség, a nettó kamatláb és a túlélési valószínúségek viszonya határozza meg. Akkor lesz meredekebb a fogyasztás pályája, tehát korral akkor nố jobban a fogyasztás, ha a háztartás türelmesebb, a kamatláb magasabb vagy magasabb a késóbbi időszak megélésének valószínúsége. A 3.14 . képletben $1 / \sigma$ mutatja meg, hogy az előbbi tényezók eredőjére milyen rugalmasan reagál a fogyasztás pályája.

A munkakínálat optimális időbeli pályáját, az előbbi két tényező munkakínálatra gyakorolt együttes hatását mutatja fiatal korban a 3.15. intertemporális összefüggés:

$$
\frac{l_{j}}{l_{j+1}}=\left\{\left(1+r_{\tau}\right) \frac{\beta \psi_{j+1} e_{j}}{\psi_{j} e_{j+1}}\right\}^{1 / \xi} .
$$

A munkakínálat tehát akkor csökken korral, ha csökken a termelékenység, illetve a fogyasztók türelmesek a piaci kamatlábhoz képest. A következő időszak feltételes túlélési valószínúsége $\left(\psi_{j+1} / \psi_{j}\right)$ kisebb, mint 1 , ezért ez a tényezô önmagában a

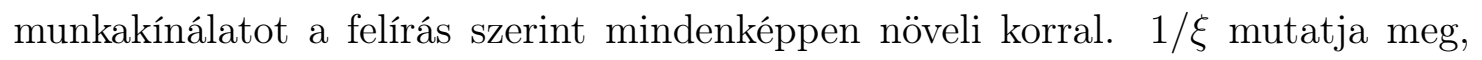
hogy az elóbbi tényezôk eredôjére milyen rugalmasan reagál a munkakínálat.

A középkorúak esetén $\left(J_{1}+1 \leq j \leq J_{1}+J_{2}\right)$ az elóbb említettekhez még egy nem hagyományos hatás is hozzájárul. További ösztönzője ekkor a munkának, hogy a keresetek késóbb a nyugdíjakat gyarapítják:

$$
l_{j}=\left[\frac{w e_{j}}{\gamma}\left(\frac{1-\tau_{l}-\tau_{b}}{1+\tau_{c}} c_{j}^{-\sigma}+\beta^{J_{1}+J_{2}-j-1} \frac{\psi_{J_{1}+J_{2}+1}}{\psi_{j}} \frac{\alpha\left(1-\tau_{l}-\tau_{b}\right) c_{J_{1}+J_{2}+1}^{-\sigma}}{\left(1+\tau_{c}\right) J_{2}}\right)\right]^{1 / \xi} .
$$

Az összefüggés második tagjából megállípítható, hogy ez a hatás erôsebb, ha magasabb a helyettesítési ráta $(\alpha)$, ha rövidebb az átlagolási időszak $\left(J_{2}\right)$, kisebb a munkajövedelem-adó $\left(\tau_{l}\right)$ és a nyugdíjjárulék $\left(\tau_{b}\right)$ kulcsa vagy magasabb a fogyasztás határhaszna (alacsonyabb a fogyasztás) a nyugdíjba vonulás idején $\left(c_{J_{1}+J_{2}+1}^{-\sigma}\right)$. Az ösztönzố erô a nyugdíjba vonulás idôpontjától távolodva gyengül a szereplók türelmetlensége $\left(\beta^{J_{1}+J_{2}-j-1}\right)$ és a nyugdíjazás megélésének alacsonyabb feltételes valószínúsége $\left(\psi_{J_{1}+J_{2}+1} / \psi_{j}\right)$ miatt $(3.16$, egyenlet). 
Az elóbb leírt hatások az ún. helyettesítési hatás kategóriájába tartoztak. Ezen kívül egy vagyonhatás is érvényesül, vagyis alacsonyabb életpálya-jövedelem mellett mind a fogyasztási cikkekból, mind szabadidóból a fogyasztó kevesebbet fogyaszt, ezért munkakínálata emelkedik. A hatás érvényesülését a modellben az intertemporális költségvetési korlát biztosítja:

$$
\sum_{j=1}^{J} \frac{\left(1+\tau_{c}\right) c_{j}}{\left(1+\left(1-\tau_{k}\right) r\right)^{j-1}}=\sum_{j=1}^{J} \frac{\left(1-\tau_{l}-\tau_{b}\right) w e_{j} l_{j}}{\left(1+\left(1-\tau_{k}\right) r\right)^{j-1}}+\sum_{j=1}^{j} \frac{b_{j}}{\left(1+\left(1-\tau_{k}\right) r\right)^{j-1}}
$$

\subsection{A paraméterek értékének megválasztása}

A modell paramétereinek jelentôs részét a megfigyelt időszak, vagyis a kétezres évek első évtizedének átlagos magyar adatai alapján igyekeztünk kalibrálni. Az értékek meghatározásának módját a következókben ismertetjük.

A termelékenységi profilokat a KSH háztartási költségvetési felvétele 1998 és 2008 közötti adatain becsültük a 21 és 65 év közötti korcsoportokra.21 A termelékenységi profil becslésében a főállásban szerzett bruttó munkajövedelem logaritmusát, mint függó változót az életkor (ami most 5 éves korcsoportokat jelent), az életkor négyzete, régiós és év kétértékú változókkal magyaráztuk. A becsléshez Heckman-féle szelekciós modellt használtunk. Ennek oka, hogy a megfigyelhető bruttó béreken a legkisebb négyzetek módszerével elvégzett becslés szelekciós torzítást okozott volna a foglalkoztatottak termelékenységének irányába, ugyanis ez nem vette volna figyelembe az éppen nem dolgozók által potenciálisan megszerezhető munkajövedelmet. A szelekciós egyenletben az elóbb felsorolt magyarázó változók mellett a háztartásban élô 23 év alatti gyermekek száma, az illetô nappali tagozatos, illetve nyugdíjas státusza, a családi állásra utaló magyarázó változók (gyerek, egyedül álló szülő, élettárs, rokon) és a családi állapotra utaló változók (nôtlen, házas, özvegy, elvált) szerepeltek ${ }^{22}$ A szelekciós torzítást mérô Mills-féle

\footnotetext{
${ }^{21} \mathrm{Az}$ adatokhoz a Magyar Nemzeti Bank Nyári Vendégkutatói Programjának jóvoltából jutottunk hozzá 2012-ben.

${ }^{22}$ A termelékenységi profilokat meghatározásánál olyan specifikációt is alkalmaztunk, ahol vagy csak a családi állásra, vagy csak a családi állapotra vonatkozó változók szerepeltek a többi ma-
} 
$\lambda$ inverzarány minden specifikációban szignifikáns, ami a szelekciós torzításra kontrolláló megközelítés alkalmazását igazolja (a Függelék 8.2, 8.3 és 8.4 táblázatai).

A modellben a kor és a kornégyzet változók alapján adódó profilokat szerepeltettük. Az eredmények szerint az alacsony képzettségúekhez képest a közepes és magas képzettségüek a 26-30 évesek között 35, illetve 106 százalékkal, az 56-60 évesek között 35, illetve 134 százalékkal magasabb termelékenységgel rendelkeznek. A közepes és magas képzettségúek legmagasabb termelékenységüket 46-50, illetve 51-55 éves korukban érik el. Ekkor az alacsony végzettségüekéhez képest a termelékenységi differencia 46, illetve 153 százalék, saját 21-25 éves korbéli termelékenységhez képest pedig 89, illetve 227 százalék. Az alacsony végzettségúek profilja lapos, az aktív munkapiaci szakasz végéig nem, csak 61-65 éves életkorban éri el a csúcsát.(3.8. ábra)

3.8. ábra. Alacsony, közepes és magas képzettségú férfiak termelékenységi korprofiljai

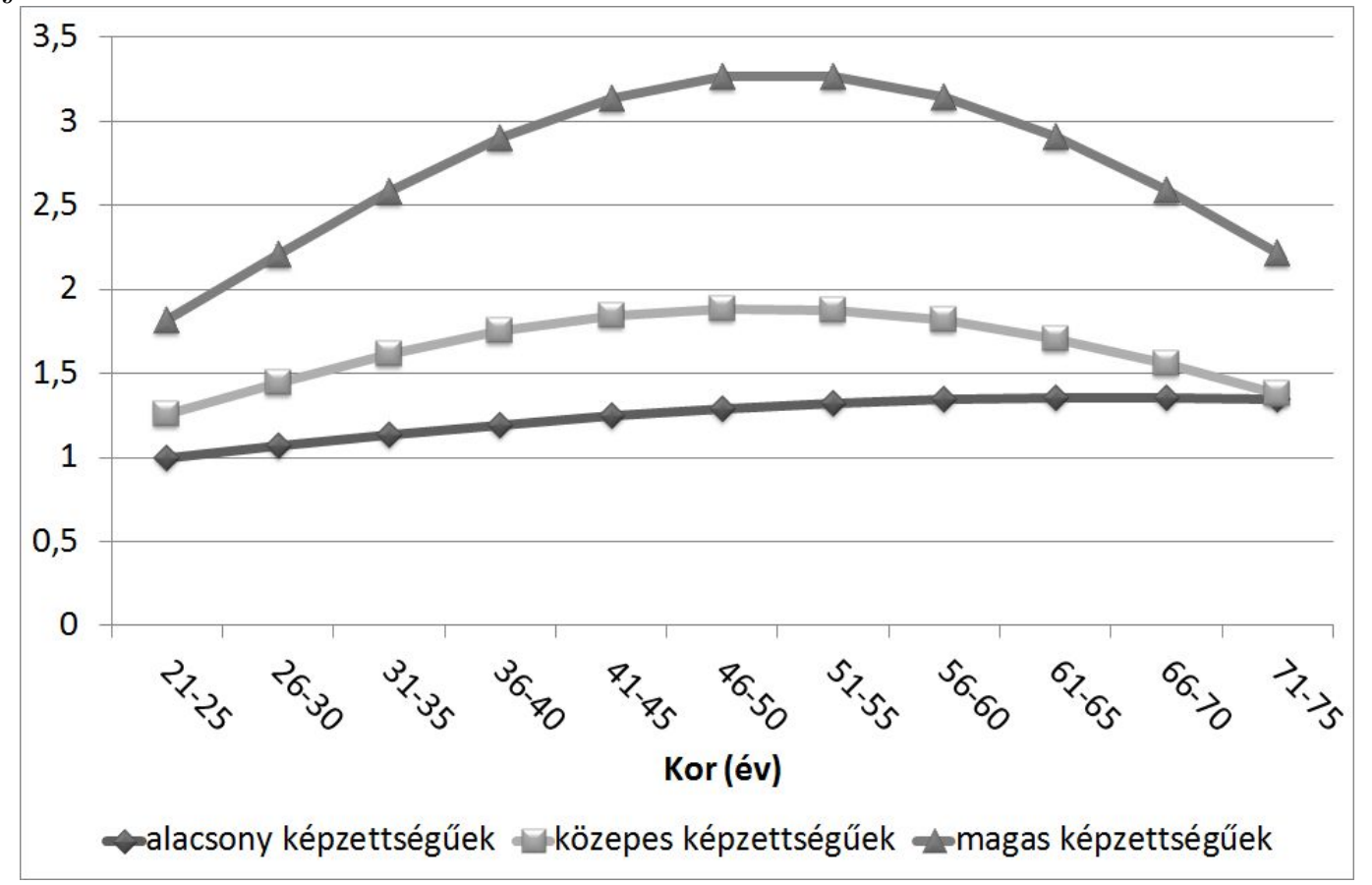

Saját számítás a HKF 1998-2008. évi adatai alapján

gyarázó változó mellett, de a számunkra lényeges becsült együtthatók ettôl nem változtak meg jelentősen. 
A túlélési valószínűségek a magyar férfiak 2001. évi halandósági táblájából származnak (KSH [2001]). A modellben csak a legalább 26 éves férfiak szerepelnek, ezért 100 százaléknak vettük annak valószínúségét, hogy egy egyén a 26 éves kort megéli. A túlélési valószínúségeket a modell szerkezetének megfelelően 5 éves életszakaszokra összesítettük.

Az Eurostat méréseire támaszkodtunk (Eurostat [2012]) a munkajövedelem, a fogyasztás és a tókejövelem implicit adókulcsainak és a nyugdíjjárulékok implicit kulcsainak kalibrálásánál. Az általunk alkalmazott kulcsok a 2000 és 2009 között implicit ráták mértani átlagai. A munkajövedelem implicit adókulcsának és a járulékkulcsnak a kiszámításánál az összes munkát terhelő implicit adót a személyeket terhelő közvetlen adók és a társadalombiztosítási hozzájárulások arányában osztottuk szét.

Az öregségi nyugdíjrendszerben az átlagos helyettesítési ráta alapesetben 75 százalék, a mindenki számára kötelező nyugdíjkorhatár 60 év (a 7. időszak vége). A nyugdíjak indexálása felerészt követi a reálbérek növekedését, a nyugdíjak kiszámításánál a nyugdíjazás elootti 7 idôszak átlagos nettó munkajövedelmét veszik figyelembe.

Az átlagos reálkamatlábat a Világbank statisztikai adatbázisából nyertük, ahol azt a vonatkozó időszak hitelkamatlábának ex post GDP-deflátor alapú mutatójaként számolták (3,77 százalék), majd ötévesítettük. Modellünkben $\lambda$ a technikai haladást és a reálbérek trendnövekedését mutatja egyben. Az egyensúlyi növekedési pálya mentén egy makromodellben a két mutató megegyezik egymással és a reál GDP növekedési ütemével. Ugyanakkor az 1999-2009. évi időszakban a magyar gazdaságban az átlagos reálbér-növekedési ütem (3,78 százalék) jelentôsen meghaladta a reál GDP növekedési ütemét (2,35 százalék). Utóbbi érték közelebb állhat a hosszú távra is tervezhetô növekedési ütemhez, ezért a kalibrálásnál ennek használtuk az ötévesített változatát.

A modell négy paraméterét (a diszkont tényező $(\beta)$, a szabadidő súlyát a pillanatnyi hasznosságban $(\gamma)$, a munkakínálat rugalmasságának reciprokát $(\xi)$ és a fogyasztás relatív kockázatkerülési paraméterét (coefficient of relative risk avers- 
ion, $C R R A)(\sigma))$, melyek a fogyasztó preferenciáit irányítják, úgy határoztuk meg, hogy az adott paraméterértékek mellett a modell által generált munkakínálati pálya és az empirikusan megfigyelhetô korosztályonkénti (26-60 éves kor közötti) átlagos foglalkoztatottsági arányok távolságnégyzeteinek összege minimális legyen a három képzettségi csoportban $\sqrt{23} \mathrm{Az}$ összes ledolgozott óra helyett megengedhető a foglalkoztatottsági arány használata, hiszen láttuk, hogy az intenzív határon a munkakínálat alig változik életkorral. A 60 év felettiek foglalkoztatási arányait nem használtuk az illesztéshez, hiszen ekkor már rendkívül alacsony foglalkoztatási arányokkal találkozhattunk, és egy olyan modellben, ahol mindenki számára kötelezô a 60 éves nyugdíjkorhatár, és nyugdíj mellett senki sem dolgozik, a munkakínálat a korhatárt követően úgyis zérus. A modellben használt paraméterértékeket a 3.1. táblázatban foglaltuk össze.

\footnotetext{
${ }^{23}$ Egy olyan modellben, ahol a munkapiac megtisztul, a munkakínálat változásai akkor esnek egybe a foglalkoztatottság változásaival, ha a munkakereslet tökéletesen rugalmas. Hallgatólagosan tehát ezt feltételeztük.
} 
3.1. táblázat. A modell paraméterei

\begin{tabular}{|l|l|}
\hline A paraméter neve & A paraméter értéke \\
\hline \hline fogyasztás adókulcsa & $\tau_{c}=0.263$ \\
tókejövedelem adókulcsa & $\tau_{k}=0.183$ \\
társadalombiztosítási hozzájáru- & $\tau_{b}=0.259$ \\
lás kulcsa & $\tau_{l}=0.143$ \\
munkajövedelem adókulcsa & $\alpha=0.75$ \\
átlagos helyettesítési ráta & $J_{2}=7$ \\
a nyugdíj megállapításánál figye- & \\
lembe vett idôszakok száma & $J_{1}+J_{2}=7$ \\
nyugdíjkorhatár & $J 3=8$ \\
nyugdíjas évek max. száma & $\nu=0.5$ \\
indexálási paraméter & $a_{l}^{0}=0, a_{l}^{1}=0.071, a_{l}^{2}=-0.004$ \\
alacsony képzettségúek termelé- \\
kenységi paraméterei \\
közepes képzettségúek termelé- \\
kenységi paraméterei \\
magas képzettségúek termelé- \\
kenységi paraméterei \\
$\begin{array}{l}\text { átlagos reálkamatláb } \\
\text { átlagos reálbér-növekedési ütem } \\
\text { túlélési valószínúségek }\end{array}$ \\
\hline \hline
\end{tabular}

Az így leírt eljárással meghatározott a preferenciaparamétereket a három képzettségi csoportra a 3.2 táblázat elsô számoszlopa tartalmazza. A diszkont tényezô jelentôs, évente mintegy 8,45 százalékos diszkontálásra utal. A CRRA paraméter reciproka, az intertemporális helyettesítési rugalmasság 1,63-as értéke némileg magasabb, mint a szakirodalomban általában kapott 0 és 1 közötti érték (Benczúr [2007]), ezért a fogyasztási pálya erôs kamatérzékenységét implikálja. ${ }^{24}$ A munkakínálat Frisch-féle elaszticitása ennél a hasznossági függvénynél konstans, értékét

\footnotetext{
${ }^{24} \mathrm{Az}$ intertemporális helyettesítési rugalmasság 1,63-as arra utal, hogy egy egyszázalékos kamatváltozás hatására a fogyasztási pálya meredeksége 1,63 százalékkal növekszik.
} 
3. fejezet: Parametrikus nyugdíjreformok és életciklus-munkakínálat

a becsült $\xi$ reciproka mutatja. A 1,39 szazalékos rugalmasság magasabb, mint a magyar adatokon becsült 0,28-as érték (Benczúr et al. [2012]), de a két eredmény nem hasonlítható össze minden további nélkül, hiszen Benczúr et al. [2012] nem Frisch-féle (intertemporális), hanem Hicks-féle (steady state) rugalmasságot becsül. Ugyanakkor a paraméter abba a 0,03 és 6,25 közötti tartományba esik, melyet Keane [2011] 13 tanulmány feldolgozása alapján határoz meg 25 ${ }^{25}$ Felmérésében azonban azok a korai tanulmányok is szerepeltek, amelyek igen nagy elaszticitást becsültek. Chetty et al. [2011] több mikroökonómiai tanulmány alapján a becsült Frisch-féle munkakínálati rugalmasságok átlagos értékét az összes munkaórára 0,82, az extenzív határon 0,28 százalékban állapítja meg. Ugyanakkor megjegyzi, hogy ezek az értékek nem konzisztensek az üzleti ciklusokat magyarázó, reprezentatív szereplőt tartralmazó makroökonómiai modellekkel, melyekben a foglalkoztatottság nagy ingadozását csak 2,82 százalékos Frisch-féle munkakínálati rugalmasság segítségével képesek magyarázni.

3.2. táblázat. Becsült preferenciaparaméterek

\begin{tabular}{|l|l|l|}
\hline A paraméter neve & 3 csoport & 2 csoport \\
\hline \hline$\beta$ & 0.643 & 0.766 \\
$\gamma$ & 1.390 & 1.293 \\
$\xi$ & 0.718 & 0.559 \\
$\sigma$ & 0.614 & 0.765 \\
\hline \hline
\end{tabular}

Mivel az alacsony képzettségúek termelékenységi profilja, amely a becslés alapjául szolgált, kései maximuma miatt nem tûnt elég meggyôzoónek, ezért kísérletet tettünk arra, hogy az alacsony képzettségúeket kihagyva, a preferenciaparamétereket kizárólag a közepes és a felsőfokú végzettségúek foglalkoztatási arányainak megfelelően becsüljük meg (3.2. táblázat második számoszlopa). A diszkont tényezô így évente körülbelül 5,2 százalékos szubjektív diszkontálást mutat. A fogyasztás intertemporális helyettesítési rugalmassága 1,31-re csökkent az elóző esethez képest, így a fogyasztási pálya kamatérzékenysége közelebb került az elfogadott

\footnotetext{
${ }^{25} \mathrm{~A}$ tanulmányokban becsült paraméterek súlyozatlan átlagánál, 0,85-nál azonban így is magasabb az általunk becsült érték.
} 
tartományhoz. A munkakínálat Frisch-féle elaszticitásának 1,79-as értéke viszont az elôzố esethez képest tovább nôtt, a nettó bérek még erôsebb hatását vonva maga után.

Bár kielégítő illeszkedésre a modell jelenlegi specifikációja alapján még nem számíthattunk, a 3.9 , ábrán látható, hogy a két magasabb képzettségi csoportnál a becsült ráták az életpálya nagyobb részén megragadják legalább a foglalkoztatás korprofiljainak alapvető irányát, a pálya görbületeit azonban az illesztett profilok nehezen tudják követni. Idôs korban mindkét képzettségi csoportban felülbecsültük a foglalkoztatás valószínûségét, fiatal korban pedig a közepes végzettségúek a becsültnél kevesebbet dolgoztak.

3.9. ábra. Magas és közepes képzettségúek megfigyelt és becsült foglalkoztatási arányai
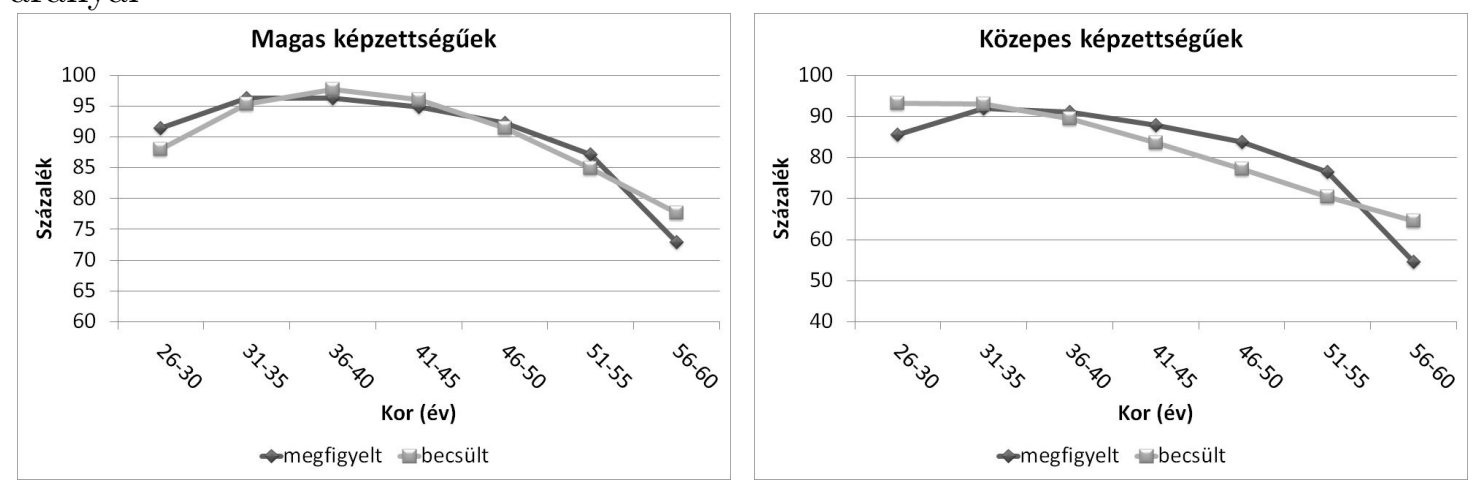

\section{6. Életciklus-munkakínálat és parametrikus nyug- díjreformok}

Hogyan reagál a munkakínálat a parametrikus nyugdíjreformokra? A felvázolt egyszerú modellkeretben az elôzőkben - magas és közepes képzettségú csoportoknak megfelelően - kalibrált paramétereket felhasználva, olyan reformokat vizsgáltunk meg, amelyek az öregségi nyugdíjrendszer fenntarthatóságát szolgálják 3.3. táb- 
3. fejezet: Parametrikus nyugdíjreformok és életciklus-munkakínálat

lázat) ${ }^{26}$ Ilyen reform az átlagos helyettesítési ráta csökkentése, a nyugdíjkorhatár megemelése, a svájci indexálás inflációt követó indexálásra való cserélése, illetve a nyugdíj kiszámításának alapjául szolgáló életpálya-átlagkeresetben figyelembe vett évek számának megemelése ${ }^{27}{ }^{28}$

3.3. táblázat. A magas és közepes képzettségú férfiak munkakínálatának százalékos megváltozása parametrikus nyugdíjreformok hatására

\begin{tabular}{|l|c|c|c|c|c|c|c|c|}
\hline \hline Korosztály & \multicolumn{2}{|c|}{ 1. reform } & \multicolumn{2}{c|}{ 2. reform } & \multicolumn{2}{c|}{ 3. reform } & \multicolumn{2}{c|}{ 4. reform } \\
\hline & Magas & Közepes & Magas & Közepes & Magas & Közepes & Magas & Közepes \\
\hline \hline 26-30 év & 2.21 & 2.12 & 1.73 & 1.92 & -2.57 & -1.99 & 2.27 & 2.21 \\
$31-35$ év & 2.11 & 2.02 & 1.42 & 1.61 & -0.70 & -0.10 & 2.27 & 2.21 \\
$36-40$ év & 1.97 & 1.88 & 0.97 & 1.17 & -0.52 & 0.07 & 2.27 & 2.21 \\
$41-45$ év & 1.76 & 1.67 & 0.32 & 0.51 & -0.27 & 0.33 & 2.27 & 2.21 \\
$46-50$ év & 1.46 & 1.37 & -0.64 & -0.45 & 0.10 & 0.70 & 2.27 & 2.21 \\
$51-55$ év & 1.01 & 0.92 & -2.02 & -1.84 & 0.64 & 1.24 & 2.27 & 2.21 \\
$56-60$ év & 0.37 & 0.28 & -4.01 & -3.83 & 1.43 & 2.04 & 2.27 & 2.21 \\
\hline összesen & 1.62 & 1.58 & 6.90 & 5.79 & -0.38 & 0.07 & 2.27 & 2.21 \\
\hline \hline
\end{tabular}

1. reform: a helyettesítési ráta csökkentése. Amennyiben a helyettesítési rátát 10 százalékponttal csökkentjük $(\alpha=0,65)$, a munkakínálat pályáját két tényezố befolyásolja. Változatlan munka mellett a reform csökkenti az életpályajövedelmek jelenértékét. Emiatt a vagyonhatáson keresztül a férfiak csökkentik mindkét képzettségi csoportban a szabadidő-fogyasztásukat, és többet kezdenek

\footnotetext{
${ }^{26}$ A mindhárom képzettségi csoportra együttesen kalibrált modell szimulációjának az eredményeit a Függelék 8.1. táblázatában közöljük.

${ }^{27}$ Ahogy korábban említettük, ezt a reformot "inverz módon", vagyis a beszámított idôszakok számának csökkentésén keresztül mutatjuk be.

${ }^{28}$ A nyugdíj kiszámításának alapjául szolgáló életpálya-átlagkeresetbe a 1999 és 2009 között megfigyelt munkavállalók minden keresete beleszámított. Az elsố életszakasz elkülönítését mégis fontosnak találtuk, hiszen az életpálya-átlagkeresetbe 1988-tól számítanak bele a keresetek, ezért a később született korosztályok számára a nyugdíjat az életpályájuk egyre nagyobb részének keresetei alapján számítják. Ezen változás munkakínálatra gyakorolt hatását a szimulációk során úgy tudtuk "inverz" módon figyelembe venni, ha az elsô életszakasz periódusainak a számát nulláról egyre emeltük.

${ }^{29}$ A 61-65 éves korosztályban a korhatáremelés reformok 0-ról rendre 66,4 ill. 56,1 százalékra emelte a magas és közepes képzettségúek foglalkoztatottsági arányát.
} 
dolgozni. A vagyonhatással szemben hat az, hogy gyengültek a munkavállalás marginális ösztönzói (3.16, egyenlet): a munka egy pótlólagos egysége a helyettesítési ráta csökkenése miatt kisebb mértékben gyarapítja a későbbi nyugdíjakat. Az eredeti pályák és a reform utáni pályák összevetéséból az is látszik, hogy a munkakínálatot csökkentô marginális hatás korral erôsödik: nyugdíjba vonulás idôpontjához közeledve az idóbeli közelség és a nyugdíjazás megélésének nagyobb esélyei miatt a fogyasztók már nem diszkontálják olyan mértékben a leendő nyugdíjból származó hasznosságot, ezért a helyettesítési ráta csökkenésére is nagyobb munkakínálatcsökkenéssel reagálnak. Az "ellenösztönzés" az 56-60 éves korosztályban olyan erôs, hogy a foglalkoztatottság már alig változik meg az alapesethez képest.

2. reform: a nyugdíjkorhatár emelése. A mindenki számára egységes nyugdíjkorhatárt a modellben egy időszakkal emeltük meg (60-ról 65 évre; $J_{1}=0$, $J_{2}=8, J_{3}=7$ ). Mivel a nyugdíjak folyósításának maximális időtartama csökkent, ezért a várható nyugdíjak jelenértéke változatlan munka mellett ismét csökkentette az összes életpálya-jövedelem jelenértékét, így ez a hatás önmagában növeli a munkakínálatot a teljes élethosszon. A hatás erősségét mérsékli, hogy a teljes életciklus-munkakínálatot most már eggyel több időszak alatt lehet ledolgozni. A vagyonhatás mellett azonban ismét megváltoznak a marginális ösztönzók is. Minden egyes munkavállalói korosztály esetében az alapesethez képest egy időszakkal, öt évvel késóbb kezdik folyósítani a nyugdíjat. A várható nyugdíjakat emiatt erôteljesebben diszkontálják, a nyugdíjaskor megélésének valószínúsége is csökken minden egyes korosztály számára, ezért a változás kevésbé teszi "kifizetôdôvé" a nyugdíjvagyon felhalmozását. A marginális hatás gyengülése egyre erôteljesebb, ahogy a nyugdíjba vonulás időpontjához közeledünk. A két hatás eredője már 46 éves kortól csökkenti a munkakínálatot. Természetesen a szabadidő-fogyasztás (és munkakínálat) simítására vonatkozó törekvéseknek köszönhetôen jelentôsen megemelkedik a modellben a korábban nem dolgozó 61-65 éves korosztály foglalkoztatási rátája (66,4 illetve 56,1 százalék).

A nyugdíjkorhatár megemelése nagymértékben, 58 illetve 54,4 százalékkal növelte az 56-65 éves korosztály foglalkoztatottságát. A nagy változás a modell azon tulajdonságának köszönhető, hogy a reform előtt a kötelező nyugdíjkorhatár után, 
3. fejezet: Parametrikus nyugdíjreformok és életciklus-munkakínálat

61-65 éves korban senkinek sem engedte meg a foglalkoztatottságot, és a preferenciaparaméterek a fogyasztót az életciklus-munkakínálat erôteljes simítására ösztönzik. Az eredményrôl azonban így sem mondható, hogy nagyságrendileg eltérne a korábbi hazai eredményektól. Benczúr et al. [2012] szerint az effektív nyugdíjkorhatár 1 éves megemelése összességében a teljes foglalkoztatottságot 1,68 százalékkal, az 55-65 éves korosztály foglalkoztatottsági arányát 4,26 százalékponttal (mintegy 12 százalékkal) emeli meg. "Arányosítva" a saját eredményeinket, egy egyéves korhatáremelésnek köszönhetően a teljes foglalkoztatottság 1,38 illetve 1,16 százalékkal, az 56-65 éves korosztály foglalkoztatottsága a két képzettségi csoportban 11,6 illetve 10,9 százalékkal bôvül a reform hatására, ami nem különbözik jelentôsen Benczúr et al. [2012] eredményétől.

3. reform: az indexálás megváltoztatása. Az alapváltozatban a nyugdíjak értékét svájci indexálásnak megfelelően módosítják, vagyis a megállapított nyugdíjak a későbbiekben felerészt a bérek (és a gazdaság) növekedési ütemét követték, felerészt az inflációt. Az elméleti keretünk reálmodell, ezért mindez a reálgazdasági növekedés 50 százalékos követését jelentette. A bevezetett reform a svájci indexálást árkövető indexálásra cseréli, tehát a nyugdíjak megtartják vásárlóértéküket $($ ind $=1)$. Az intézkedés valamennyi dolgozó korosztály munkakínálatát megemelte. A 3.3. táblázatból az is látszik, hogy a foglalkoztatottság minden korosztályban ugyanolyan arányban változott. Ennek az oka, hogy a reform nem változtatja meg a koronként eltérő erôsségű marginális ösztönzőket, csak a várható nyugdíjak jelenértékét csökkenti. Az életpálya-jövedelmek visszaesése így az összes érintett korosztályban 2,27 illetve 2,21 százalékkal növelte a foglalkoztatottak arányát a két képzettségi csoportban.

4. reform: az átlagolási időszak csökkentése. A nyugdíjkorhatár megemelése a modellben valójában két reform együttes hatását tükrözte, ugyanis amellett, hogy a nyugdíjkorhatár megemelkedett, a nyugdíjak kiszámításához felhasznált évek száma is nőtt. A két hatás elkülönítésére a modellben egy további "reformként" a nyugdíjfelhamozó szakasz hosszának csökkentését is szimuláltuk. Reformnak természetesen a nyugdíj kiszámításához figyelembe vett évek számának emelését gondoljuk, azonban az alapváltozatban minden aktív időszak munkajöve- 
delme beleszámított a nyugdíj alapjául szolgáló életpálya-átlagkeresetbe $\left(J_{1}=0\right)$, ezért a reformnak csak az ellentettjét tudtuk szimulálni $\left(J_{1}=1, J_{2}=6, J_{3}=8\right)$. A reform tanulmányozását az is indokolja, hogy Magyarországon az 1988 óta nyugdíjba vonulók esetén valóban emelkedik azoknak az éveknek a száma, amelyeket a nyugdíjak alapjául szolgáló életpálya-átlagkeresetek kiszámításakor figyelembe vesznek.

Az átlagolási idôszak hosszának csökkenésével alacsonyabb termelékenységú időszak kerül ki a nyugdíj kiszámításából, és ez növeli a nyugdíj alapjául szolgáló nettó életpálya-átlagkeresetet, és így az induló nyugdíj értékét is. A vagyonhatáson keresztül ez kevesebb munkára ösztönzött az egész életpálya során. A marginális ösztönzés ugyanakkor az elsô idôszakot leszámítva javult: rövidebb idôszak átlagjövedelme szolgál a nyugdíj alapjául, ezért az egyes évek jelentősége a nyugdíjhoz való hozzájárulás tekintetében nôtt (3.16. egyenlet), és ez a munkakínálatot növeló hatás a nyugdíjkorhatárhoz közeledve egyre erôsebb. A legfiatalabb korosztály keresetei a reform után már nem szolgálnak a késóbbi nyugdíjuk alapjául, így ebben az életkorban a vagyonhatás jelentősen csökkentette a munkakínálatot. A magas képzettségűeknél 45, a közepes képzettségűeknél 35 éves korig a negatív vagyonhatáshoz képest még nem játszik olyan fontos szerepet a marginális ösztönzók javulása, ezért a munkakínálat itt is csökken. Idősebb korban azonban már a pozitív marginális ösztönző hatás dominál, a munkakínálat életkorral egyre erôteljesebben nő az alapváltozathoz képest.

\section{Aggregált változások az egyes képzettségi csoportok foglalkoztatott-}

ságában. Az egyes képzettségi csoportok korosztályonként megoszlásának felhasználásával összegeztük az egyes korosztályok foglalkoztatottságának a növekedését. ${ }^{30}$ Legkedvezóbb foglalkoztatási hatása a bemutatott reformok közül a szimuláció szerint az ötéves korhatáremelésnek van, amely a magas képzettségűek között 6,9, a közepes képzettségúek között 5,79 százalékkal emelte meg a foglalkoztatottak számát. A helyettesítési ráta 10 százalékpontos csökkentése 1,62, illetve 1,58, az indexálás megváltoztatása 2,27, illetve 2,21 százalékkal emelte a két csoportban együttesen a

\footnotetext{
${ }^{30} \mathrm{Az}$ arányok meghatározásánál Hablicsek [2010] férfiakra vonatkozó iskolai végzettség szerinti népesség-előrejelzésének 2004. évét használtuk. Az aggregált hatások tehát mechanikus összegzés eredményei, semmilyen közvetett általános egyensúlyi visszacsatolással nem számoltunk.
} 
3. fejezet: Parametrikus nyugdíjreformok és életciklus-munkakínálat

foglalkoztatottságot. A nyugdíj alapjául szolgáló életpálya-áltagkeresetbe beszámító évek számának csökkentése a foglalkoztatottságot összességében 0,38 százalékkal csökkentette a magas képzettségúek, és 0,07 százalékkal növelte a közepes képzettségúek esetében.

\subsection{Következtetések}

A nyugdíjreformoknak a nyugdíjrendszer fenntarthatóságára gyakorolt hatását több ízben értékelték már a hazai irodalomban. Az elemzések mindvégig a foglalkoztatási viszonyok változatlanságának feltételezésével vagy exogén megváltoztatásával számoltak. A reformok rövid távú hatásának értékelésénél ez aligha jelent problémát, de hosszú távon létezhetnek olyan viselkedési, munkakínálati reakciók, amelyek árnyalják a képet.

Ebben az írásban arra tettünk egy első kísérletet, hogy strukturális, optimalizáló szereplőket feltételezố megközelítés segítségével meghatározzuk néhány alapvetô parametrikus nyugdíjreformnak a férfiak életciklus-munkakínálatára gyakorolt hatását.

A magyar férfiak 1999 és 2009 közötti átlagos életciklus-munkagörbéinek és nyugdíjba vonulási jellemzőinek a bemutatását követően felvázoltuk egy életciklusmunkakínálati modell alapjait, amelynek paramétereit a magyar gazdaság 1999 és 2009 közötti jellemzőinek megfelelően kalibráltuk. A parametrikus nyugdíjreformok életciklus-munkakínálatra gyakorolt hatásainak elemzésekor két hatást különítettünk el. Amennyiben egy reform változatlan munka mellett csökkentette a várható nyugdíjak jelenértékét, akkor a vagyonhatáson keresztül összességében növelte a munkakínálatot a teljes életciklus során. A másik tényező a nyugdíjfelhalmozás marginális ösztönzőinek megváltozása. A társadalombiztosítási nyugdíjrendszer fenntarthatóságát szolgáló reformok esetén 31 a munkavállalás marginális ösztön-

\footnotetext{
${ }^{31}$ Reformnak a helyettesítési ráta csökkentése, a korhatáremelés és a svájci indexálás árindexálásra történô cserélése mellett természetesen nem a nyugdíj kiszámításának alapjául szolgáló életpálya-átlagkeresetbe beszámító évek számának csökkentését, hanem a növelését gondoljuk.
} 
zői csökkennek, ezért azok - a nyugdíjkorhatárhoz közeledve egyre erôteljesebben - a munkakínálatot csökkentik.

Eredményeink szerint a helyettesítési ráta csökkentése, a nyugdíjkorhatár emelése és az indexálás megváltoztatása összességében növeli az egyes képzettségi csoportok munkakínálatát, míg a nyugdíj alapjául szolgáló életpálya-átlagkeresetbe beszámító évek számának megváltozása nem jár jelentôs aggregált hatással. A reformok azonban az összevont hatások mellett átcsoportosítják a munkakínálatot a korosztályok között. Hosszú távon a reformok a nyugdíjfelhalmozás életkorral fokozódó marginális ösztönzőinek a gyengülése miatt a munkakínálatot a fiatalabb korosztályok felé tolják el. A helyettesítési ráta csökkentése még a két hatás eredôjeként valamennyi korosztályban emelte a foglalkoztatást, de a korhatáremelés és az átlagolási idôszak növelése csökkentette a reform előtt is dolgozó idősebb munkaképes korosztályok foglalkoztatását. Ezzel együtt a korhatáremelés újabb, korábban már egyáltalán nem dolgozó korosztályt vont be a munkaerópiacra, ezért a 6165 éves, illetve összességében az 56-65 éves korosztály foglalkoztatása jelentősen nőtt. A másik három reformtól eltéróen az árkövető indexálás bevezetése minden korosztályban azonos mértékben növelte a foglalkoztatást, hiszen a bevezetése a marginális ösztönzôket nem érintette.

Annak ellenére, hogy a kapott eredmények alapvető várakozásainknak megfelelnek, munkánk csak egy kezdeti lépésnek tekinthető az életciklus-munkakínálat és a nyugdíjrendszer kapcsolatának vizsgálatában, ugyanis a modell még nem képes a foglalkoztatási profilok idősebb korban megfigyelhető meredek, képzettségi csoportonként eltérô mértékú visszaesését reprodukálni. Az idôskori munkakínálat erôteljesebb visszaesését támogatná, ha a munkakínálati döntésen belül elkülönülne az alkalmazkodás intenzív és extenzív határa, amit például a munkaerô-piaci részvétel esetén felmerülő fix költség bevezetésével lehet megoldani. Fontos tényezô még a nyugdíjrendszer részletesebb leírása: a nettó keresetek és a nyugdíjak közötti kapcsolat gyengítése a degresszivitás és a minimális nyugdíj bevezetésével és a korai nyugdíjba vonulás lehetôsége eltérô nyugdíjba vonulási és foglalkoztatottsági mintázatokat eredményezhet a különböző képzettségi csoportokban. Az egészségi állapot, a munkaképesség romlása az életkor előrehaladtával szintén olyan ténye- 
zők, amelyek idôsebb munkavállalói korban az alacsonyabb aktivitást indokolhatják, ezért fontosnak tartjuk megjelenítésüket. 


\section{4. fejezet}

\section{Demográfiai átmenet és}

parametrikus nyugdíjreformok

\section{hatása a gazdasági növekedésre és a nyugdíjrendszer fenntarthatóságára}

\subsection{Bevezetés}

Napjainkban az állam a fejlett világban mindenhol jelentős szerepet vállal az időskorúak nyugdíjbiztosítási rendszerének múködtetésében. A nyugdíjrendszer megfelelô múködésének két alapvető kritériuma, hogy a nyugdíjaknak elégséges szintú megélhetést kell biztosítania idős korban, másrészt a rendszernek fenntarthatónak kell lennie, vagyis nem rakhat túlságosan nagy terhet finanszírozása az állami költségvetésre. A fejlett országok többségében a nyugdíjrendszer finanszírozása javarészt felosztó-kiróvó (pay-as-you-go) alapon történik, azaz az aktuálisan befolyó járulékokból finanszírozzák a nyugdíjjáradékokat, a járulékfizetések alapja pedig a munkajövedelem. Ilyen körülmények között - a nyugdíjrendszer adott paraméterei mellett - a járulékfizetők és a nyugdíjjáradékban részesülők arányának alakulá- 
sa kulcsfontosságú a nyugdíjrendszer fenntartható múködése szempontjából. Az említett arány alakulása a demográfiai és a foglalkoztatási viszonyok függvénye.

Magyarországon az elkövetkezó évtizedben a demográfiai viszonyok hullámzó romlására lehet számítani. A foglalkoztatási viszonyok európai összehasonlításban rosszak, ugyanakkor az elôreszámítások szerint a munkapiaci aktivitás kis mértékú javulása várható a közeljövôben. A két hatás eredőjeként az egy 20-64 éves aktívra esô idôsek (65 év felettiek) száma töretlenül fog emelkedni, és a század második felétôl már a második csoport létszáma lesz nagyobb.

Magyarországon a közelmúltban Orbán és Palotai [2005], [2006] és a Nyugdíj és Időskor Kerekasztal (Holtzer szerk. [2010]) egyaránt végzett szimulációkat, amelyben számításokat készítettek a nyugdíjrendszer valamilyen fenntarthatósági mutatójának jövôbeli alakulásáról különböző nyugdíjreformok mellett. A fent említett megközelítésekben azonban közös, hogy egyik sem klasszikus makroökonómiai modellt használ. Hosszú távon azonban a viselkedési reakciók és az általános egyensúlyi visszacsatolások fontosak lehetnek.

Az együttélố nemzedékeket (overlapping generations, $O L G$ ) tartalmazó makromodellek közül a két együttélő generációt tartalmazók (pl. Diamond [1965]) ugyan képesek fontos kvalitatív következtetéseket levonni a nyugdíjrenszer makroökonómiai hatásairól, de a demográfiai viszonyok változásainak szimulációjára nem alkalmasak, mivel nem képesek a bonyolult demográfiai folyamatok megjelenítésére. Realisztikus szimulációra véleményünk szerint leginkább az Auerbach és Kotlikoff [1987] írásának hagyományaira épülő, együttélő korosztályokat tartalmazó modellcsalád képes, ugyanis a nemstacionárus demográfiai folyamatokat könnyen értelmezhetően tudja megjeleníteni, általános egyensúlyi modell, és a szereplők reagálnak benne a nyugdíjrendszer változásaira. A tanulmányban a modellcsalád általános ismertetését követôen bemutatjuk egy magyar adatokra kalibrált kis, nyitott gazdaság OLG modelljét, ahol a fogyasztók megtakarítása és munkakínálata is endogén, majd elemezzük benne a demográfiai átmenet és a parametrikus nyugdíjreformok hatását. 
4. fejezet: Demográfiai átmenet és parametrikus nyugdíjreformok hatása a gazdasági növekedésre és a nyugdíjrendszer fenntarthatóságára

A tanulmány felépítése a továbbiakban a következő szerkezetet követi. A második részben bemutatjuk a magyar nyugdíjrendszer fenntarthatóságára nagy befolyást gyakorló tényezóket: a demográfiai és foglalkoztatási folyamatokat valamint a nyugdíjrendszer paramétereit. A harmadik fejezetben ismertetjük azt az irodalmat, amely a nyugdíjreformok, illetve a demográfiai átmenet hatását vizsgálják a nyugdíjrendszer fenntarthatóságára. A negyedik fejezetben felvázoljuk a szimuláció során alkalmazandó modellkeretet, meghatározzuk a modell paramétereit, jellemezzük a gazdaság kiinduló állapotát, bemutatjuk, hogy miként hat a demográfiai átmenet a gazdaságra a modell alapváltozatában, majd azt is, hogy egyes parametrikus reformok hogyan módosítják a hatását.

\subsection{A nyugdíjrendszer fenntarthatóságát befolyáso- ló tényezôk}

\subsubsection{Demográfiai folyamatok}

Az éppen élő munkavállalók járulékfizetéseiből finanszírozott felosztó-kiróvó nyugdíjrendszerek fenntarthatósága nagyban függ a nyugdíjjáradékban részesülook és a járulékfizetôk arányától. Egyelőre eltekintve attól, hogy nem minden munkaképes korú dolgozik, a potenciálisan járulékot fizetôk és a járadékban részesülók arányát az előreszámítások szerint kedvezôtlen irányba fogja módosítani a közeljövóben több demográfiai folyamat is. Magyarországon ugyanis a demográfiai viszonyok trendje, a fejlett világhoz hasonlóan az ún. demográfiai átmeneten ment-megy keresztül: a születések számának csökken, a várható élettartam viszont emelkedik. A folyamat azonban közel sem egyenletes, ami miatt a körülmények pillanatnyilag viszonylag kedvezőek, de a közeljövőben számottevő romlás várható majd.

A népesség születéskor várható élettartama az 1960-2010-es időszakban emelkedett: a férfiaknál 65,9 évről 70,5, a nóknél 70,1 évrôl 78,1 évre nôtt. A növekedés a nôk esetében egyenletesnek mondható, a férfiak mutatója azonban a rendszerváltást követôen a mintegy három évtizednyi visszaesés után kezdett újra emelkedni. 
Az OECD országok közül a nők születéskor várható élettartama 2010-ben csak Mexikóban és Törökországban volt alacsonyabb a magyar értéknél, a férfiaké pedig a legalacsonyabb a közösségben (OECD [2014]).

A teljes termékenységi rátd ${ }^{1}$ értéke Magyarországon 1960-ban 2,02, 1990-ben 1,84 volt, 2010-re azonban 1,25-ra csökkent. Utóbbi érték - bár a csökkenô trend általában a többi OECD országban is megfigyelhető - az OECD országok közül a legkisebbek között van, kizárólag Dél-Korea, Portugália és Szlovákia mutatója marad el tôle (OECD [2013]). A teljes termékenységi ráta értéke a népesség természetes reprodukcióját biztosító 2,1 footôl is jelentôsen elmarad, ami mérsékelt bevándorlási szintek mellett is önmagában a népesség fogyásához fog vezetni. A nyugdíjrendszer egyenlegének közép- és hosszú távú előrejelzése szempontjából az is lényeges, hogy a termékenységi ráta esetén a csökkenés a második világháborút követően nem volt egyenletes: a Ratkó-generáció és a gyerekeinek a születése a teljes termékenységi mutatót az 50-es és a 70-es években jelentôsen a csökkenô trend fölé emelte.

Az említett folyamatok az időskori eltartási rátát (száz 20-64 évesre jutó 65 évnél idôsebbek száma) 1960 és 2010 között 14 fơról 26,3 foore növelték 4.1. ábra). A növekedés üteme nem volt egyenletes: a ráta az 1980-as években idóleges visszaesett, az ekkor nyugdíjba vonuló, az elsô világháború idején született generációk kisebb létszáma miatt. A 2010-re elért érték a térség többi országához viszonytva magasnak számít (minimális mértékben Bulgária, Észtország, Lettország és Horvátország értékei haladják meg), viszont a nyugat-európai értékektől elmarad (OECD [2013]).

\footnotetext{
${ }^{1}$ A népességi termékenységi folyamatainak jellemzésére gyakran használt mutató a teljes termékenységi ráta, amely egy nô által szült gyerekek átlagos számát mutatja, amennyiben "követi" az adott idôpontban keresztmetszetben megfigyelhető korspecifikus termékenységi profilt, és megéri a termékeny idôszak végét.
} 
4. fejezet: Demográfiai átmenet és parametrikus nyugdíjreformok hatása a gazdasági növekedésre és a nyugdíjrendszer fenntarthatóságára

4.1. ábra. Az időskori függőségi ráta Magyarországon, 1950-2010.

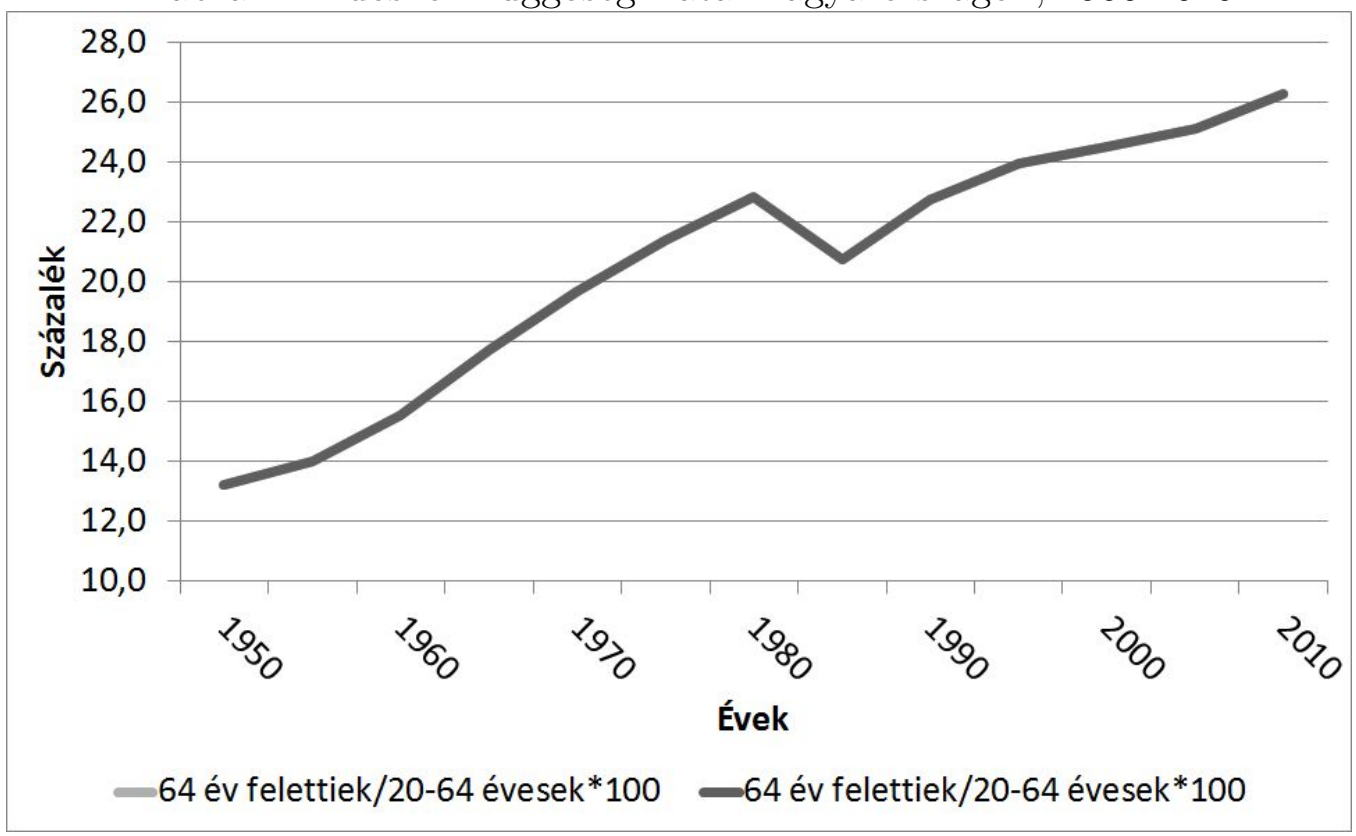

Forrás: World Population Prospects [2010]

Ugyanezen demográfiai mutatók jövőben várható értékeinek jellemzésénél a továbbiakban Hablicsek [2010] demográfiai elốreszámításának alapváltozatára támaszkodunk. Az alapváltozat szerint a teljes termékenységi ráta az 1,34 körüli értékról 2020-ig 1,5-re emelkedik, majd ezen a szinten stabilizálódik, miközben a gyereket szülő nôk átlagos életkora 27,6 évról 31 évre emelkedik. A születéskor várható élettartam a férfiaknál a 2001. évi 68,3 évről 90 évre, a nőknél 76,7 évrôl 95 évre nố 2100-ig. ${ }^{2}$

A fenti folyamatok eredőjeként az időskori függőségi ráta a 2010-es 26 körüli értékrôl meredeken emelkedik, 2100-ra 100 munkaképes korúra már 80 idôs korú fog jutni 4.2. ábra). Az eltartási ráta növekedése ugyanakkor nem egyenletes: a 2010-es évek közepén, a 2040-es és a 2070-80-as években meredekebben emelkedik, nyilvánvalóan a nagyobb létszámú Ratkó-generáció, azok gyerekeinek és unokáinak megöregedése miatt. A nyugdíjrendszerre tehát a népesség öregedése - változatlan

\footnotetext{
${ }^{2} \mathrm{Az}$ alapváltozat ezen kívül még a nettó bevándorlás 5000 fôs csökkenésével is számol 2020-ig a 2006-os 20000 fő körüli szinthez képest.
} 
paraméterek és foglalkoztatási viszonyok mellett - növekvő terheket fog rakni, és az említett három hullámban a nyugdíjbavonulók száma gyorsabban nô majd.

4.2. ábra. Időskori függőségi ráták előrevetítése Magyarországon, 2001-2100.

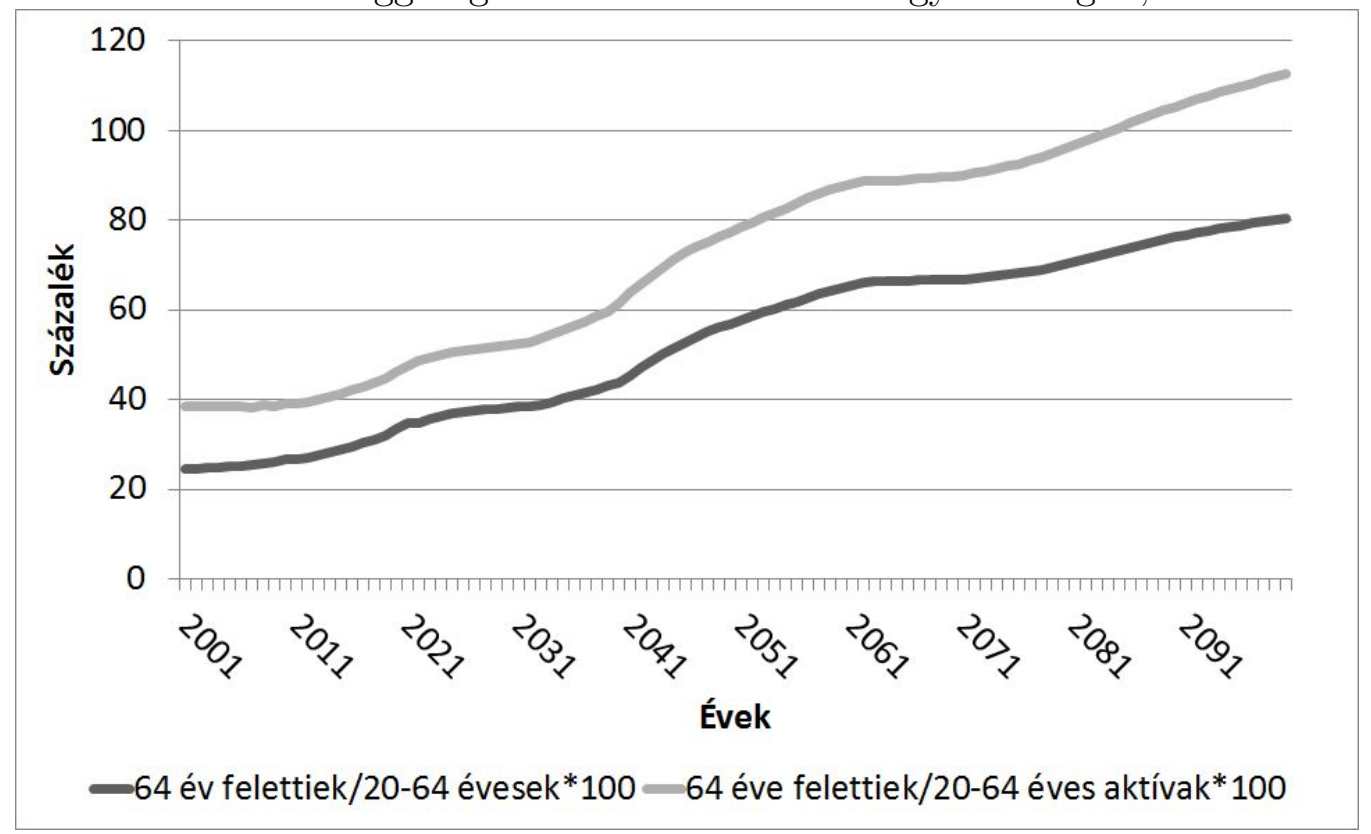

Forrás: Hablicsek [2010]

\subsubsection{Munkapiaci aktivitás}

Az időskori függőségi arány emelkedése természetesen a gyakorlatban nem jelenti azt, hogy a nyugdíjrendszer az elôrevetített demográfiai folyamatokkal azonos mértékú terhet ró majd a költségvetésre. A nyugdíjrendszer fenntarthatósága szempontjából lényeges arány az egy foglalkoztatottra jutó nyugdíjasok száma. A foglalkoztatottak ugyanis járulékot fizetnek, ezáltal javítják a nyugdíjkassza egyenlegét, ugyanakkor a foglalkoztatás jövóbeni nyugdíjkövetelést keletkeztet, ezért a jövôbeli egyenlegeket rontja. Az idôsebb munkavállalók esetén a foglalkoztottság kétszeresen is fontos: amellett, hogy a foglalkoztatottak járulékot fizetnek, ezzel párhuzamosan legtöbbször nem élnek a nyugdíjazás lehetőségeivel. 
4. fejezet: Demográfiai átmenet és parametrikus nyugdíjreformok hatása a gazdasági növekedésre és a nyugdíjrendszer fenntarthatóságára

Annak ellenére, hogy a nyugdíjrendszer fenntarthatósága szempontjából a foglalkoztatottság bír kiemelt jelentôséggel, a továbbiakban a potenciálisan foglalkoztatottak, a gazdaságilag aktív népesség alakulásával foglalkozunk. Hosszú távú előrejelzéssel ugyanis csak a munkakínálatra vonatkozóan rendelkezünk, a késóbbekben alkalmazott makromodellben pedig megtisztul a munkapiac, tehát az aktívak és a foglalkoztatottak száma megegyezik.

Magyarországon a rendszerváltást követôen a gazdaságban olyan drasztikus változások történtek (átállás a piacgazdaságra, korábbi piacok elvesztése, csôdtörvény, privatizáció), melyek hatására nagy visszaesés következett be a foglalkoztatásban: a '90-es évek közepére az 1989-es szinthez képest mintegy 30\%-kal esett. Az állásukat elvesztôk közül sokan munkanélküliek, sokan inaktívak lettek (utóbbiak egy része valójában a fekete gazdaságban talált munkát). Az idôsebbek számára az átmeneti segélyezés és átképzés helyett a kormányok az előrehozott nyugdíj és a rokkantnyugdíj lehetőségével biztosították, hogy végleg elhagyják a munkaerőpiacot. Az 1997-es mélypontot követően, amikor a 20-64 évesek aktivitási rátája 63,4 \%-os volt, a munkakínálatban fokozatos javulás volt megfigyelhetô, melynek eredményeként értéke 2012-re 69,6 \%-ra emelkedett. A növekedés ellenére az elmaradás Európa Unió fejlett részéhez (EU15), de még a hasonló fejlettségú visegrádi országokhoz képest sem szûnt meg (4.3. ábra). 
4.3. ábra. Aktivitási ráta a 20-64 évesek körében a visegrádi országokban, 19982012.

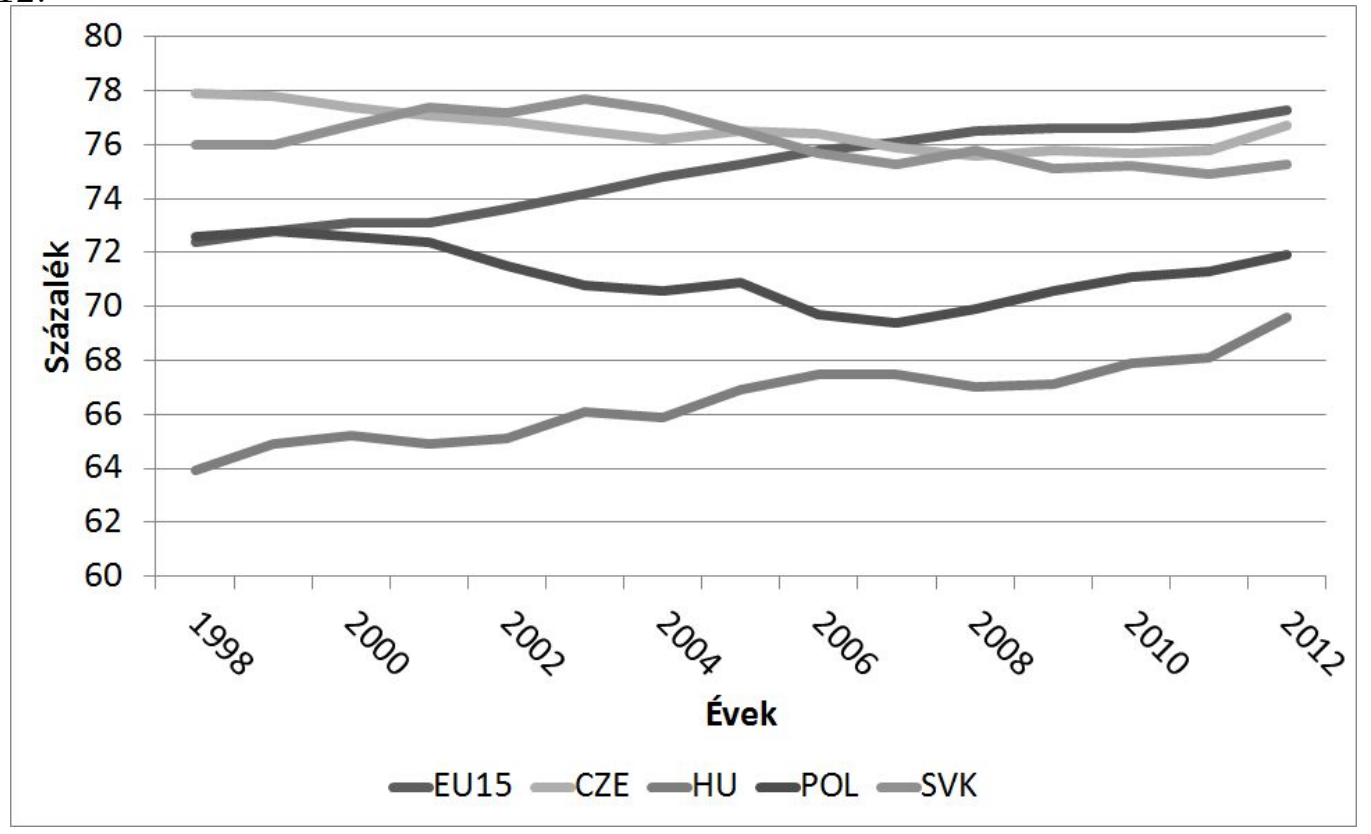

Forrás: Eurostat

Kátay [2009] az aktivitási rátát nem, kor és képzettség szerint bontja fel, és a csoportok közül kiemeli azokat, amelyek esetében jelentős az elmaradás az EU15 országokhoz képest. A csoportok: az 50-64 évesek, az alapfokú végzettséggel rendelkezốk, a fiatalok és a szülóképes korú nók. Az egyes csoportok munkakínálati viselkedésének a változásai az adott idôszakban jól magyarázhatók a vizsgált idôszakban az öregségi- és rokkantsági nyugdíjrendszer, az oktatás és a gyerektámogatási rendszer múködésének változásaival. Az aktivitási ráta változását az egyes csoportok aktivitási rátája mellett a munkaképes korú népesség összetételéból eredô hatás okozza. Összetételhatásként a múltban javította a rátát a Ratkó-unokák munkába állása, és javította a rátát az is, hogy az időszak során nôtt az egymást követô generációk iskolázottsági szintje. A tanulmány publikálása óta több olyan kormányzati intézkedést hoztak, melyek az aktivitási ráta meredekebb emelkedéséhez járultak hozzá. $!^{3}$

\footnotetext{
${ }^{3}$ Ilyen többek között a nyugdíjkorhatár emelése, a korkedvezményes nyugdíjak visszaszorítása, a rokkantnyugdíjak felülvizsgálata, a szociális rendszer szigorítása.
} 
4. fejezet: Demográfiai átmenet és parametrikus nyugdíjreformok hatása a gazdasági növekedésre és a nyugdíjrendszer fenntarthatóságára

Az aktivitási viszonyok hosszú távú elörejelzésénél megint Hablicsek [2010] tanulmányára hagyatkozunk $4^{4}$ Fóként az iskolázottsági expanziónak és kis részben a nyugdíjkorhatár-emeléseknek köszönhetôen az aktívak aránya a 20-64 évesek között az évszázad elsô felében jelentôsen emelkedik. Késóbb azonban az idôsebb, alacsonyabb aktivitású csoportoknak a népességöregedés miatt megemelkedik az aránya a 20-64 évesek között, ami az aktivitási ráta visszaesését okozza (4.4 ábra).

4.4. ábra. Aktivitási ráta előreszámítása Magyarországon, 2001-2100.

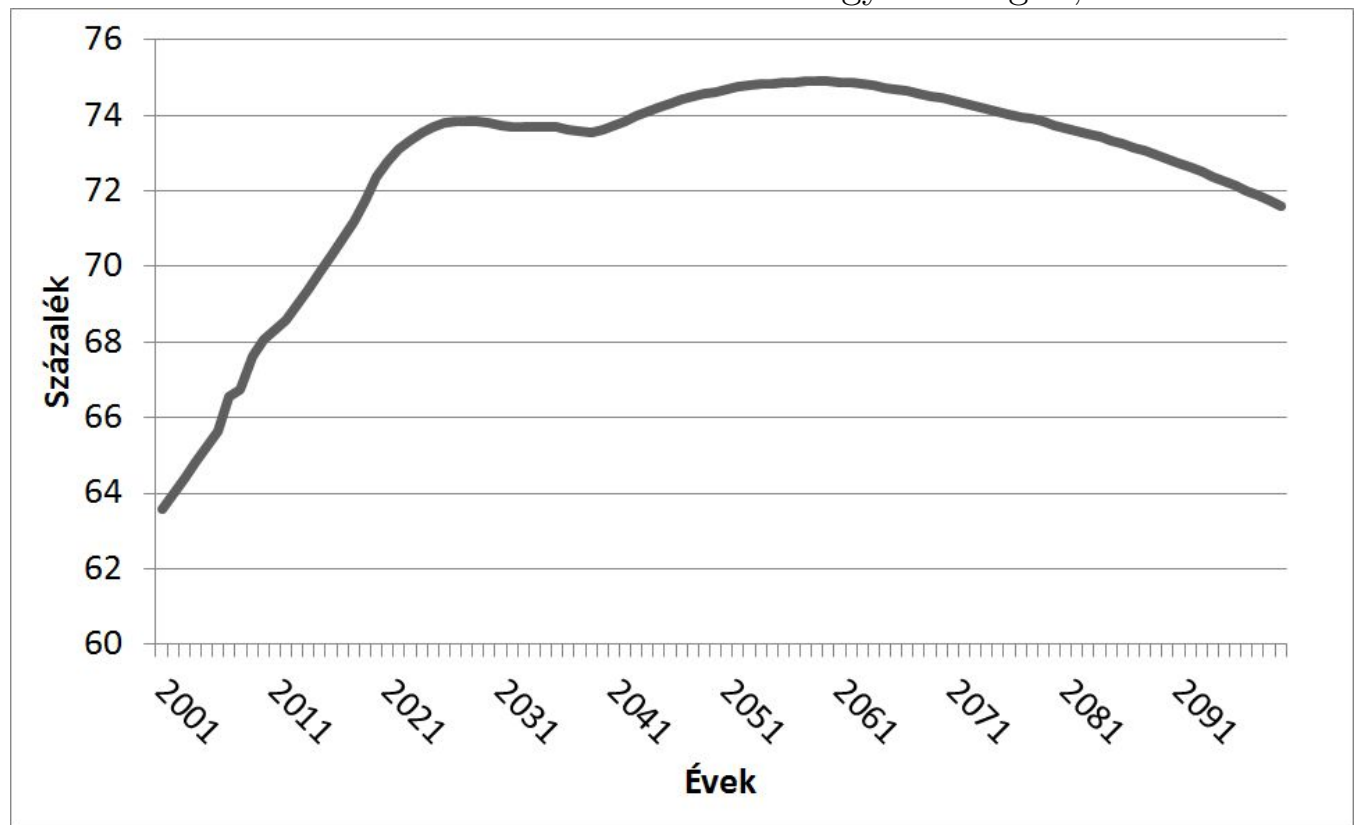

Forrás: Hablicsek [2010]

A 4.2. ábrán látható, hogy a 20 és 64 év közötti aktívakra jutó idősek aránya 2001-ben mintegy 38\%, ami 2100-ig 112 \%-ra emelkedik, tehát ekkora már meghaladja az idősek száma a 20-64 éves aktívakét. Az idôskori eltartási rátával összevetve látható, hogy a kedvezô aktivitási folyamatok miatt az idôszak elején a két mutató között még csökken is a különbség, a késóbbiekben viszont az aktivitás visszaesése tovább rontja a nyugdíjrendszer fenntarthatóságát a demográfiai trendekhez képest is.

\footnotetext{
${ }^{4} \mathrm{Az}$ előreszámítás hipotéziseinek részletes leírásáról lásd: Hablicsek [2010] 129. oldalát.
} 
Meg kell jegyezni, hogy az ilyen módon árnyalt mutató még akkor sem mutatná a nyugdíjrendszer fenntarthatóságára nehezedő, pusztán a két populáció (a nyugdíjasok és a járulékfizetők) arányából következő nyomást, ha mindenki egységesen 65 évesen vonulna nyudíjba. A minimális nyugdíjjogosultsághoz ugyanis 20 év szolgálati időre van szükség. Augusztinovcs és Köllő [2007] számításai szerint a rendszerváltás utáni idôszakot jellemzô töredezett munkapiaci pálya miatt az 1945 után született generációk egyre nagyobb hányada nem fogja tudni a minimális szintet teljesíteni: a 15 vizsgált generáció közül 60 éves korban átlagosan $21 \%$ nem szerez nyugdíjjogosultságot, de az arány a fiatalabb generációk felé romlik. Ebből kifolyólag a 65 év feletti népesség száma a jövốben - a jelenlegi szabályok szerint nagyobb lesz, mint a nyugdíjasoké. Igaz, a jogosultságot nem szerzók egy jelentős hányadáról várhatóan ugyanúgy az államnak kell gondoskodni más formában, tehát összességében csak a nyugdíjrendszer terheit csökkentik, az állami költségvetését nem.

\subsubsection{A nyugdíjrendszer}

A korábban megismert demográfiai és foglalkoztatási folyamatokon felül a nyugdíjrendszer fenntarthatóságának alakulására a nyugdíjrendszer paraméterei hatnak. 5

- 2010-ig Magyarországon három pilléres nyugdíjrendszer múködött (kötelezô társadalombiztosítás, kötelező magánnyugdíj és önkéntes nyudíj). A 2010ban elfogadott új nyugdíjtörvények a két kötelező ág közül csak az egyiket tették választhatóvá, és a korábbi magánnyugdíjpénztár-tagoknak csupán kis hányada maradt a második pillérben. A közelezô tókefedezeti rendszer jelentősége minimálisra csökkent, ezért ennek ismertetésétől eltekintünk, és az

\footnotetext{
${ }^{5}$ A parametrikus nyugdíjreformokon felül a társadalombiztosítási nyugdíjrendszernek elképzelhetôk radikálisabb, szerkezeti reformjai, melyek bevezetésének lehetôségéról Holtzer szerk. [2010] ír, azonban ebben az írásban ezekkel nem foglalkozom.
} 
4. fejezet: Demográfiai átmenet és parametrikus nyugdíjreformok hatása a gazdasági növekedésre és a nyugdíjrendszer fenntarthatóságára

elsô pilléren belül is elsôsorban a közelmúltban fennálló rendszer legfontosabb paramétereire koncentrálunk 6

- Járulékok szintje. A 2012-ben megszünő, munkáltatókat terhelő társadalombiztosítási járulék helyére lépô szociális hozzájárulási adó kulcsa 2014-ban 27\%, a biztosítottak és a magánnyugdíjpénztári tagok által fizetett nyugdíjjárulék kulcsa $10 \%$ volt. A nyugdíjjárulék levonásának a felső határa 2012-ben évi 7.942.200 forint volt, amely 2013-ra megszünt.

- Korhatár és korkedvezmény. Jelenleg az öregségi nyugdíjkorhatár 62 év, mely egy hosszabb emelési periódus eredményeként állt elő. A 2009-es törvényi változások hatására azonban az 1952-es generációnak már 62 és fél év az öregségi nyugdíjkorhatára, ami egy fokozatos átmenet után az 1959 után születettek számára már 65 évre emelkedik. A jogosultság további feltétele minimálisan 20 év szolgálati idô megszerzése 77 2012 elôtt az elôrehozott öregségi nyugdíj korhatára a férfiak esetén 2, a nők esetén 3 évvel maradt el az öregségi nyugdíjkorhatártól. A teljes összegú ellátáshoz szükséges szolgálati idő előrehozott nyugdíj esetén 40, csökkentett összegú ellátás esetén 37 év volt, ahol a csökkentés mértéke a nyugdíj megállapításától az öregségi nyugdíjkorhatár betöltéséig terjedő idôtartamtól, és a 40 (korábban 37) év szolgálati időbôl hiányzó időtartamtól függött. Az előrehozott nyugdíj lehetősége azonban 2012-től megszûnt. Az előrehozott öregségi nyugdíjon kívül több öregségi nyugdíjként múködő forma létezett (például korengedményes, korkedvezményes nyugdíj), amelyek az elórehozott nyugdíjnál is alacsonyabb korban tették lehetôvé a nyugdíjba vonulást, ezek azonban 2012-tôl szintén megszúntek, illetve más, nem nyugdíjszerû ellátássá alakultak. Az új szabályok értelmében azonban a nôk 40 szolgálati év után kortól függetlenül is nyugdíjba mehetnek.

\footnotetext{
${ }^{6}$ A magyar nyugdíjrendszer pontos jellemzôit, fejlődéstörténetét leírja pl. Augusztinovics et al. [2002], Orbán és Palotai [2006], Simonovits [2009a], Holtzer szerk. [2010] és Simonovits [2011], paramétereit összehasonlítja más országokéval Kovács [2008].

${ }^{7}$ Öregségi résznyugdíjhoz minimálisan 15 év szolgálati idő szükséges.
} 
- A kezdó nyugdij értékének meghatározása. Az induló nyugdíjak meghatározásának alapja a nyugdíjba vonulást megelőzó évek nettó béreinek átlagos nettó bérnövekedéssel valorizált átlaga. Az átlagolási periódusba alapesetben az 1988-tól elért nettó keresetek számítanak bele. Az így számolt átlagkeresetnek csak egy degresszív skálának megfelelő hányada vehetô figyelembe, azonban a degresszivitási tábla értékhatárai a törvényi elő́rások alapján gyorsan nônek. Egy további, szolgálati évektôl függó tényezô határozza meg, hogy a korrigált átlagos nettó keresetek mekkora hányada a kezdő nyugdíj értéke. A tényezô a korábbiakkal ellentétben már egyenletesen díjazza az addicionális éveket, vagyis a skála "kiegyenesedett", ezzel párhuzamosan azonban az átlagos szintje csökkent (Augusztinovics, Köllő [2007]). A teljes öregségi nyugdíjnak van minimális értéke (2014-ben 28 500Ft).

- A nyugdíjak indexálása. 2010-tól a korábbi svájci (felerészt béreket, felerészt árakat követô) indexálást az árindexálás váltotta fel.

\subsection{Demográfiai átmenet és a nyugdíjreformok ha- tásainak szimulációja}

\subsubsection{Nyugdíjreformok fenntarthatóságra gyakorolt hatását vizsgáló ad hoc modellek}

A demográfiai átmenet jelensége a nyugdíjrendszerek átalakítását vagy legalábbis az átalakítási igények megfogalmazását váltotta ki a fejlett országokban. A változások gyakran csak a járulékbefizetési, illetve járadékkifizetési szabályok paramétereit befolyásolták (parametrikus reformok), míg máshol a nyugdíjrendszer alapvetô múködésbeli jellemzőit is módosították (szerkezeti, paradigmatikus reformok). A kérdés, hogy az előrevetített demográfiai folyamatok mellett hogyan változik meg a nyugdíjkassza fenntarthatósága különbözô nyugdíjreformok hatására, Magyarországon is a közgazdászok érdeklődésének homlokterébe került (pl. Benczúr [1999], 
4. fejezet: Demográfiai átmenet és parametrikus nyugdíjreformok hatása a gazdasági növekedésre és a nyugdíjrendszer fenntarthatóságára

Rocha, Vittas [2002], Orbán, Palotai [2005], Orbán, Palotai [2006], illetve Holtzer szerk. [2010]). A tanulmányok közül, melyek módszertanilag sok hasonlóságot mutatnak, a teljességre nem törekedve az MNB nyugdíjmodelljével készült két legutóbbi munkát (Orbán, Palotai [2005], [2006]), illetve Holtzer szerk. [2010] alapjául szolgáló szimulációs modellt emeljük ki.

Orbán és Palotai [2005] tanulmányában az MNB nyugdíjmodelljével végrehajtott szimulációk segítségével azt számszerüsíti, hogy a magyar nyugdíjrendszer 1997/1998-as reformja óta bekövetkezett intézkedések (a járulékkulcsokat nem emelték a reform idején elhatározottaknak megfelelően és további járulékcsökkentéseket terveztek, bevezették a 13. havi nyugdíjat és nyugdíjkorrekciót irányoztak elő) miként súlyosbították a nyugdíjrendszer fenntarthatóságát, növelték a nyugdíjrendszer implicit adósságállományát. Ezen kívül kiszámolják azt is, hogy a második pillér bevezetése javította-e a fenntarthatóságot. Orbán, Palotai [2006] az MNB nyugdíjmodelljével végrehajtott szimulációk segítségével azt vizsgálja, hogy a fennálló magyar nyugdíjrendszer különbözô paramétereinek változtatásával (nyugdíjkor-határ emelése a várható élettartamnak megfelelően, árindexálás bevezetése) hogyan lehet a nyugdíjrendszer hiányát, implicit adósságállományát lefaragni.

Mindkét jegybanki tanulmány mögött olyan modell áll, amely a demográfiai folymatok mellett, szakértői becslésekre támaszkodva exogénként kezeli a reálGDP- és reálbér-növekedést, a kamatlábat valamint a munkaerópiacon az aktivitási és munkanélküliségi folyamatokat. A elsô tanulmányban a tőkefedezeti pillér bevezetésének elemzésénél kifejtik, hogy az intézkedés lényegében csak időben hozza előre a költségvetés hiányát, ugyanakkor lábjegyzetben megjegyzik, hogy a megtakarításokra, aktivitásra gyakorolt közvetett hatásokat figyelmen kívül hagyták. A második tanulmányban megjegyzik, hogy a modellben nem tudják kezelni az egyes intézkedések munkaerôpiacra és az államháztartás egyéb alrendszereire gyakorolt hatásait. A nyugdíjkorhatár emelésének szimulációjánál azt is leírják, hogy az aktivitási ráták korévek szerinti eloszlásának elôreszámítása exogén, az idősebbek aktivitása nem reagál a korhatáremelésre, csak egy emelkedő trendnek megfelelôen nô. 
A Nyugdíj és Időskor Kerekasztal tevékenységét bemutató jelentés (Holtzer szerk. [2010]) sok egyéb érdekes tanulmány mellett néhány, a szerzőcsoport által perspektivikusnak talált, paradigmatikus nyugdíjreform bevezetésének lehetôségét latolgatja.8 A számításokhoz mikroszimulációs modellt használnak, amellyel a nyugdíjalap egyensúlyára gyakorolt hatásának kimutatása mellett társadalmi hatásvizsgálat is végezhetô. A Jelentés megállapításaival az egyes paradigmákat illetôen nem foglalkozom, kizárólag az alapjukat szolgáltató modell (Horváth [2010]) felépítésével.

A hatásvizsgálatok elvégzéséhez használt modellben a jegybanki tanulmányokhoz hasonlóan a demográfiai folyamatok mellett, szakértői becslésekre támaszkodva exogénként kezeli a reál-GDP-növekedést és a hozamokat. A foglalkoztatottság előreszámításánál Hablicsek [2010] munkakínálati előreszámítására támaszkodnak. Kategóriákat képeznek az évben ledolgozott napok száma alapján, meghatározzák a munkaerőállomány induló eloszlását a kategóriák között, majd korosztályonként és nemenként, múltbeli adatok alapján átmenet-valószínúségeket becsülnek a kategóriák között. Végül ennek és a munkakínálati elôrejelzésnek a segítségével jelzik előre a foglalkoztatottságot. Az átmeneti valószínúségek kortól, nemtôl és időtől függetlenek és "emlékezet nélküliek". A bérek növekedésének meghatározása a szintén szakértői becsléseken nyugvó - bérinflációt és az ún. "előléptetési fizetésemeléseket" veszi alapul.

Maguk a szerzók is megjegyzik, hogy a hatásvizsgálati modell nem tudott "visszacsatolási körökekkel operálni", azaz nem volt képes számszerúsíteni, hogy "...az ösztönzô vagy ellenösztönzô nyugdíjrendszer maga mennyiben hatna vissza pozitívan vagy negatívan a foglalkoztatási és a járulékfizetési helyzetre." (Holtzer szerk. [2010] p. 22.). A szerzók véleménye szerint a foglalkoztatási háttér, amely a járulékfizetési idôt és a relatív kereseteket befolyásolja, elsôsorban nem a nyugdíj-

\footnotetext{
${ }^{8}$ A paradigamtikus reformok a következók: 1. a pontrendszeres nyugdíjparadigma, 2. egy 65 éves kor felett járó, adókból finanszírozott alapnyugdíjjal kiegészített, csökkentett pontrendszer, 3. névleges egyéni számlás rendszer 70 éves kor felett garantált minimumnyugdíjjal, 4. távlatilag csak magánnyugdíjat adó, addig pedig egyéni számlás nyugdíjrendszer, 70 éves kor felett garantált minimumnyugdíjjal, illetve 5. távlatilag tisztán adókból finanszírozott alapnyugdíjat tartalmazó rendszer.
} 
4. fejezet: Demográfiai átmenet és parametrikus nyugdíjreformok hatása a gazdasági növekedésre és a nyugdíjrendszer fenntarthatóságára

rendszertől függ. Máshol viszont azt írják, hogy a "...a nyugdíjreformra vonatkozó elgondolások legtöbbjéról feltételezhetô, hogy visszacsatolási körök is kialakulhatnak benne..." (Holtzer szerk. [2010] p. 31.), az elvégzett hatásvizsgálat mégsem építette be óket az átfogó módszertani megoldások hiánya és a szúkös idôkeret miatt. A munkakeresleti oldal beépítése saját bevallásuk szerint is szükséges lett volna, azonban nem találtak olyan szakértôt, aki ilyen hosszú távú prognózisra vállalkozott volna.

Általánosságban elmondható, hogy az eddig alkalmazott megközelítések a fóbb makroökonómiai változók pályáját szakértői becslések alapján határozzák meg, a munkakínálati és megtakarítási reakcióktól eltekintenek, tehát figyelmen kívül hagyják a demográfiai folyamatoknak és a nyugdíjrendszer változásainak a lehetséges visszahatását a munkavállalók viselkedésére. A téma irodalma szerint azonban a viselkedési reakciók fontosak lehetnek. Egy reform, amely hatást gyakorol a nyugdíjvagyon/járulékkulcsok értékére a szereplők munkakínálati döntésére hathat vissza. A költségvetést megterhelő nyugdíjkasszahiány eladósodás híján valamelyik torzító adó emelését válthatják ki, amelynek szintén lehet hatása a háztartások (munkaerőpiaci) viselkedésére. A nyugdíjrendszert tehát érdemes együtt kezelni az általános költségvetéssel. A felosztó-kiróvó nyugdíjrendszer másik gyakran vizsgált hatása, hogy bevezetése/méretének növelése csökkenti-e a megtakarításokat, visszaveti-e a tőkefelhalmozási folyamatokat (például Feldstein [1995]). Az említett viselkedési reakciók eredményeként megváltozhat a tőkeállomány és a foglalkoztatottak száma, amely a reálbérekre és a kamatlábra is visszahathat.

\subsubsection{Az Auerbach-Kotlikoff típusú modellek általános fel- építése}

A nyugdíjrendszerek makroökonómiai modellezéséhez egy olyan modellkeretre volt szükség, ahol egyszerre több korosztály él együtt, és különbözik az egyes korosztályok viselkedése. Ehhez szolgáltatott alapot Samuelson [1958], késóbb Diamond [1965] úttörő munkái által kifejlesztett, együttéló nemzedékeket tartalmazó (overlapping generations, OLG) modellcsalád. A két periódusig élő szereplőket tartal- 
mazó modellek azonban inkább csak kvalitatíve képesek annak hatásmechanizmusát illusztrálni, hogy hogyan hat a nyugdíjrendszer a makrogazdaság pályájára, kvantitatív következtetések levonására nem alkalmasak, mivel nem képesek elég árnyaltan megjeleníteni a demográfiai folyamatokat. A kvantitatív következtetések megfogalmazására képes, együttélő korosztályokat tartalmazó modellek közül a továbbiakban én csak az Auerbach és Kotlikoff [1987] alapmunkájára épüló irányzattal foglalkozom. 9

Auerbach és Kotlikoff [1987] Samuelson [1958] és Diamond [1965] munkáira építette a megközelítés alapkövének számító modelljét. A megközelítés sok tekintetben hagyományos, determinisztikus makroökonómiai modellnek számít, külön a háztartások döntését érdemes kiemelni. Az elődök munkájával ellentétben az eredeti felírásban 55 korosztály él egymással párhuzamosan. Az éppen munkapiacra lépő, egységesen 55 időszakig élő háztartások életpálya-hasznosságát időben szeparálható CES hasznossági függvény adja meg:

$$
U=\sum_{j=1}^{55} \beta^{j-1} \frac{1}{1-\frac{1}{\gamma}}\left[c_{j}^{1-1 / \rho}+\alpha l_{j}^{1-1 / \rho}\right]^{\frac{1-\frac{1}{\gamma}}{1-1 / \rho}}
$$

ahol $c_{j}$ a háztartás fogyasztása, $l_{j}$ a háztartás szabadidő-fogyasztása. $\beta, \gamma, \rho$ és $\alpha$ rendre a diszkont tényezô, az inter- és intratemporális helyettesítési rugalmasság és a szabadidő súlya a preferenciákban. A munkaerőpiacra újonnan belépók a

$$
\sum_{j=1}^{55}\left[\left(1-l_{j}\right) h_{j} w-c_{j}-T_{j}\right](1+r)^{1-j}+\sum_{j=j_{R}}^{55} b_{j}(1+r)^{1-j}=0
$$

intertemporális költségvetési korlát mellett maximalizálják a korábban megadott életpálya-hasznosságukat. Az egyenletben $r$ a kamatláb, $h_{j}$ a háztartás hatékonysága, amely az egyes életpálya-szakaszokban változhat, $w$ a hatékonysági egységre jutó reálbér $T_{j}$ a több adónemet tartalmazó nettó adókat jelöli, beleértve a társadalombiztosítási hozzájárulásokat, $j_{R}$ a nyugdíjbavonulás korhatára (innentól $l_{j}=1$ ),

\footnotetext{
${ }^{9}$ Egy másik modellcsalád Blanchard [1985] és Yaari [1965] tanulmányaira épül. Az ilyen dinamikus sztochasztikus általános egyensúlyi modelleket rendre használják fiskális politikai akciók hatásainak kvantitatív elemzéséhez (lásd pl. Kumhof és Laxton [2009]). A modellkeret számtalan erôssége van, azonban az öregedési folyamat speciális felírása a demográfiai sokkok értelmezését nehézkessé teszi.
} 
4. fejezet: Demográfiai átmenet és parametrikus nyugdíjreformok hatása a gazdasági növekedésre és a nyugdíjrendszer fenntarthatóságára

$b_{j}$ pedig a nyugdíj értéke. A háztartások szabadidő-fogyasztása egyre normált, ezért a maximalizálási feladathoz tartozik a $l_{j} \leq 1$ korlát is.

A modell részletesen írja le az adó- és járulékrendszer sok tulajdonságát (az eredeti írás címe sem speciálisan nyugdíjkérdésekre utal: "Dinamikus fiskális politika"). Az egyes, eltérô létszámú korosztályok optimalizáló viselkedésükból levezetett munka- és tókekínálatukkal és fogyasztásukkal jelentkeznek a munka-, tôke- és árupiacon. A kínálati döntések egy reprezentatív vállalat munka- és tókekeresleti függvényével (a piacokon természetesen szerepel az állam is) együtt határozzák meg egyensúlyban a reálbért és a tôke hozamát, az általános egyensúlyelméleti megközelítésnek megfelelően.

Egy tipikus szimulációban az aktuális fiskális politikához kalibrálják a gazdaság induló állandósult állapotát, majd meghatároznak egy új fiskális politikához tartozó záró állandósult állapotot, és az odáig vezető átmenetet. Az igen hosszú átmenet modellezése a nyugdíjrendszerek szempontjából fontos, mert lehetséges, hogy egy változás hosszú távon növeli minden korosztály jólétét, de az átmenet alatt élő generációk jóléte romlik. Az aggregált jóléti hatás (máskor aggregált hatékonyság) számszerúsítésének céljából Auerbach és Kotlikoff [1987] egy ún. "egyösszegú transzfereket újraelosztó hatóságot" (lump sum redistribution agency; LSRA) fejlesztett ki. A hatóság a reform idején élő korosztályokat egyösszegú adók és transzferek segítségével kompenzálja úgy, hogy helyreállítsa jólétük azon szintjét, amit reformok híján élvezhettek volna. Ha ezek után az LSRA vagyona pozitív marad, akkor a reform javította az aggregált hatékonyságot, ellenkezô esetben rontotta.

A likviditási korlát hiánya és a biztos élethossz miatt magánmegtakarítások segítségével a szereplők tökéletesen képesek biztosítani magukat időskorukra, ezért egy kötelezô magánnyugdíjrendszer bevezetésének nincs hatása. Ugyanakkor egy felosztó-kiróvó nyugdíjrendszer erôforrásokat csoportosít át a fiataloktól az idôsek felé és csökkenti, kiszorítja a tőkefelhalmozást.

A modellcsaládot a későbbiekben egyre inkább speciálisan a nyugdíjrendszer hatásainak tanulmányozására használták, ezért az összetevőit ennek megfelelően módosították. Auerbach és Kotlikoff munkája óta a legfontosabb változások, ame- 
lyek a modellt a nyugdíjreformok hatásainak szimulálására alkalmassá tették a demográfiai átmenet során, a következôk voltak.

- A demográfiai szakértók által elörejelzett demográfiai folyamatok (születések, halálozások, várható élettartam és a migráció alakulása, melyek mind hatnak a népesség korosztályok közötti eloszlásának alakulására) exogén megjelenítése a modellben.

- A halálozási kockázat bevezetése. A 100\%-nál kisebb túlélési valószínúség a türelmetlenségi tényezôhöz hasonlóan magasabb jelenbeli fogyasztásra és kevesebb munkára sarkallja a háztartásokat. A felosztó-kiróvó nyugdíjrendszer biztosítási szerepet tölthet be, kiküszöbölve a bizonytalan élet-hosszból eredő kockázatokat, ezért ez a tulajdonsága növelheti a háztartások hasznosságát.

- Örökség. A maximális élethossz előtt bekövetkezett halálozásokból nem szándékolt örökség keletkezik, melyet valamilyen módon szét kell osztani a modell résztvevôi között. Ennek mechanizmusa modellenként eltér: a nem szándékolt örökséget szétoszthatják bizonyos generációk között egyenletesen, kimunkáltabb demográfiai struktúra alapján az elhalálozott csoportok gyerekeihez juthat, vagy egyszerűen a kormány kaphatja meg. Egy másik kérdés a szándékolt örökség. A legtöbb esetben nem szerepel a modellekben, ezért ha végigélik a maximális életpályahosszt, a háztartások nem hagynak örökséget. Amikor mégis megjelenik a szándékolt örökség, mivel a háztartásoknak haszna származik belóle, akkor ezt azzal indokolják, hogy az idôsek az empirikus megfigyelések alapján nem élik fel olyan ütemben a megtakarításaikat, mint ahogy azt az életciklus-modell mutatná altruista motívumok nélkül.

- Életpálya-termelékenység. A modellek figyelembe veszik, hogy a reálbérek egy élet során szisztematikus ívet írnak le. Ezt a makromodellben a munkahatékonyság korspecifikus alakulásaként jelenítik meg, az összes reálbér pedig a hatékonysági egységre jutó reálbér, a munkakínálat és a hatékonyság szorzata. A korspecifikus termelékenységi tényezô értékei a modell számára exogének, mikroszintű béradatok segítségével becslik meg őket. A jellemzően 
4. fejezet: Demográfiai átmenet és parametrikus nyugdíjreformok hatása a gazdasági növekedésre és a nyugdíjrendszer fenntarthatóságára

fordított U-alakú profil miatt a munkakínálat a leghatékonyabb években a legmagasabb.

- Likviditási korlát bevezetésével megakadályozható, hogy az alacsonyabb termelékenységú fiatal években, a késóbbi magasabb jövedelem reményében a háztartások eladósodnának. Magasabb idôskori nyugdíjak növelik a késói évek jövedelmét, ezért az eladósodási hajlam még erôsebb lehet.

- A bizonytalan életpályahossz mellett, bizonytalan lehet a munkapiaci helyzet is (reálbér, foglalkoztatás), ami ellen szintén biztosítást jelenthet a felosztókiróvó nyugdíjrendszer (pozitív jóléti hatás). Bizonytalan jövedelmek esetén a szereplők (megfelelő hasznossági függvény esetén) óvatossági megtakarítást képeznek, ezért csökken a hajlandóság az eladósodásra fiatal korban is.

- A modellekben részletesen leírt nyugdíjrendszer szerepel, amely degresszivitást, alsó ás felsô korlátokat és minden olyan elemet képes megjeleníteni, amely a magyar nyugdíjrendszer szempontjából fontos. Amennyiben a munkakínálat nem exogén a modellben, a felosztó-kiróvó nyugdíjrendszer bevezetése torzítja a munkakínálati döntést.

- Korosztályon belüli heterogenitás. Az egyes reformok nem csak az egyes korosztályokat, hanem az egyes korosztályokon belüli (jövedelem vagy képzettség szerinti) csoportokat is eltérốen érinthetik, ezért a modellekben bizonyos fokú generáción belüli heterogenitás is megjelenhet, hogy tükrözze a nyugdíjrendszerek ilyen irányú redisztribúciós szerepét.

- Korai nyugdíjazás lehetôsége. A legtöbb nyugdíjrendszerben a nyugdíjba vonulás nem csak egy rögzített korban lehetséges, hanem egy bizonyos intervallumon belül bármikor. A modellek egy részében az egyes háztartások optimálisan választják meg a határok között ennek időpontját.

- Munkakinálat az intenzív és extenzív határon. Az életpálya során az összes ledolgozott órák száma változékony. A váltakozás részben a munkavállalók által ledolgozott órákban, részben a foglalkoztatottságban következik be. A legújabb modellek megkülönböztetik a két határt. 


\subsubsection{Demográfiai átmenet és nyugdíjreformok szimulációja A-K modellekkel}

Auerbach-Kotlikoff-féle modellt használ a német demográfiai átmenet hatásainak szimulációjához Fehr [2000], majd az aktuális nyugdíjrendszer reformjainak hatását szimulálja, és megvizsgálja, hogy miként változik a reformok hatására a makrogazdaság pályája, a szereplók jóléte és a nyugdíjrendszer fenntarthatósága, amit a nyugdíjrendszer egyensúlyát biztosító nyugdíjjárulék nagyságával mér. A reformok között mérsékelteket (pl. a nyugdíjkorhatár emelése, a nyugdíjak fokozatos csökkentése) és radikálisakat (erôteljesebb, igaz fokozatos nyugdíjcsökkentés a járulék-nyugdíj kapcsolat javításával vagy megszüntetésével) különböztet meg. A felhasznált modellben megjelenik a demográfiai átmenet, a generációkon belül öt jövedelemkvintilist különböztet meg, akiknek az életpályatermelékenységük eltér, az adó- és nyugdíjrendszer szorosan követi a német rendszer jellemzőit. A modellben nem jelenik meg bizonytalanság sem az élethossz, sem a jövedelmek tekintetében, és nincs örökség. A nyugdíjkasszát a járulékkulcsok változása, a költségvetést a fogyasztási adóé tartja egyensúlyban. A tanulmányban már nyomon követhetők a modellcsaládban múködô legfontosabb mechanizmusok, alapvető következtetései közül sok a késóbbi tanulmányokban is megismétlődik.

A demográfiai átmenet során, a 2020. utáni évtizedekben a munkaerőállomány és a tôkeállomány is csökken, a fogyasztás is mérséklődik. A munka és a tôke pályájának megfelelôen a reálbérek ezen időszak alatt nőnek, a kamatláb pedig mérséklődik. Ebben az idôszakban a fogyasztási adó kulcsának és a járulékkulcsnak is emelkedni kell ahhoz, hogy a költségvetés és a nyugdíjrendszer kiegyensúlyozott maradhasson.

Valamennyi szigorító reform hatására nőnek a megtakarítások és a tőkeállomány. A magasabb tőkeállomány megemeli a béreket, a foglalkoztatás pedig a járulék-nyugdíj kapcsolat megszüntetésének esetétől eltekintve szintén bővül.

A nyugdíjrendszer fenntarthatóságát valamennyi reform javítja, mert csökkentik a nyugdíjkassza egyensúlyához szükséges járulékkulcsot. A korhatáremelés könnyí- 
4. fejezet: Demográfiai átmenet és parametrikus nyugdíjreformok hatása a gazdasági növekedésre és a nyugdíjrendszer fenntarthatóságára

tő hatása az elsô baby boom nyugdíjba-vonulásának idején tetôzik. A nyugdíjcsökkentés kedvező hatásai inkább hosszú távon jelentkeznek: a megtakarítások növekedése megemeli a tókeállományt és a béreket, ezért a munkakínálat is nô, ami a nyugdíjjárulék csökkentését engedi meg. Hosszú távon a járulék-nyugdíj kapcsolat erôsítésével összekötött radikális kiadáscsökkentés az előbbi reakciókat még erôsebbé teszi, amely a nyugdíjjárulék még nagyobb csökkentését teszi lehetôvé. Ha azonban a radikális kiadáscsökkentést a járulék-nyugdíj kapcsolat megszüntetése kíséri, a munkakínálat kissé visszaesik, de az alacsonyabb kiadások miatt a járulékkulcsok így is jelentősen csökkenthetôk.

A reformok bevezetése idején élő idősebb munkavállalók jólétét a változások csökkentik, a fiatalabb, és meg sem született korosztályokét viszont emelik. A radikális reformok esetében a negatív jóléti hatás több generációt érint és erôsebben, mint a mérsékelt reformoknál. Az aggregált hatékonyságot azonban a járuléknyugdíj kapcsolat megszüntetésének esetétôl eltekintve valamennyi reform növelte, leginkább éppen a járulék-nyugdíj kapcsolatot erôsítô radikális reform.

A jövedelmek bizonytalanságának jelentőségét mutatja Nishiyama és Smetters [2007] tanulmánya, akik a nyugdíjak és a járulékok párhuzamos, 50\%-os csökkentésének jóléti hatásait vizsgálták az Egyesült Államokban. Modelljükben a munkavállalók jövedelmét meghatározó képességeket idioszinkretikus sokkok érhetik, a szereplők likviditási korlátokkal szembesülnek.

A reform bevezetése fokozatos, a már nyugdíjban részesülők nyugdíját nem érinti. A bevezetés idején élő legtöbb korosztály jóléte csökken, hiszen nekik kell az átmenetet finanszírozni magasabb adók formájában. A késôbb születendő korosztályok viszont jól járnak: a többletmegtakarítások miatt megemelkedett tókeállomány növeli a béreket, a kisebb állami kiadások miatt alacsonyabb járulékokat és adókat kell fizetniük. Az aggregált hatékonyság azonban csökken, ugyanis a felosztó-kiróvó nyugdíjrendszer jólétet csökkentô, munkakínálattorzító és likviditási hatásai mellett fokozottabban jut érvényre a jólétet növelő biztosítási szerepe a bizonytalan jövedelmek miatt. A biztosítási funkció annál gyengébb, minél szorosabb a kap- 
csolat a befizetett járulékok és a nyugdíjak között.10 Érzékenységvizsgálatukban megmutatják, hogy ha a jövedelmek determinisztikusak lennének, akkor a modell szerint a privatizáció növelné a hatékonyságot.

A makromodellek egyik csoportjában a korai nyugdíjkorhatár és a törvényes nyugdíjkorhatár között a háztartások meghatározhatják nyugdíjba vonulásuk idôpontját. Sánchez Martín [2010] spanyol nyugdíjreformok hatását demográfiai átmenet mellett szimuláló modelljét sikeresen kalibrálja a spanyol háztartások effektív nyugdíjba vonulási kormintázatának megfelelően. Ebben a korosztályon belüli heterogenitás megjelenítése különösen fontos szerepet játszik, ugyanis a relatíve magas minimális nyugdíj az alacsonyabb jövedelmű háztartások esetében vonzó perspektíva, óket bátorítja a munkaerôpiac korai elhagyására (a keresetüket meghatározó becsült termelékenység pedig már jóval a nyugdíjba vonulás elótt csökkenni kezd). Késóbb a modellt historikus és hipotetikus nyugdíjreformok hatásainak szimulációjára használja.

A szimuláció eredményei szerint az 1997-es nyugdíjreform, amely a nettó bérek átlagolási időszakát bơvítette a nyugdíjakat meghatározó képletben, az idősebb korosztályok körében a nyugdíjba vonulás késleltetését okozta, ami (a több felhalmozott tôke miatt magasabb bérekkel együtt) a nettó implicit adósságot kis mértékben csökkentette. Ugyanakkor a 2001-es reform, amely a korai nyugdíjazás lehetôségét több fiatalabb korosztályra is kiterjesztette, csökkentette a nyugdíjba vonulás korcentrumát. A korai nyugdíjazás újabb fellendülése a nyugdíjrendszer fenntarthatóságának javulását teljes mértékben visszafordította.

A hipotetikus reformok közül az átlagolási periódus drasztikus emelése a nyugdíjképletben eltérô reakciókat vált ki az idôsebb munkavállalók egyes csoportjaiban. A magasabb jövedelmúek a korábbiakhoz hasonlóan késóbb vonulnának nyugdíjba, a közepes jövedelmú csoportok nyugdíjának visszaesése azonban olyan mértékú, hogy érdemesebb a korai nyugdíjkorhatáron minimális nyugdíjért folyamodniuk. A fiatalabb korosztályok a reform után már mind többet és tovább dolgoznának.

\footnotetext{
${ }^{10}$ Hasonló indíttatású tanulmányában a német nyugdíjrendszert vizsgálva Fehr, Kallweit, Kindermann [2011] azt mutatja ki, hogy hatékonysági szempontból nem optimális, ha a nyugdíjrendszerben felhalmozott pontok tökéletesen tükrözik a relatív jövedelmeket.
} 
4. fejezet: Demográfiai átmenet és parametrikus nyugdíjreformok hatása a gazdasági növekedésre és a nyugdíjrendszer fenntarthatóságára

Összességében a munkakínálat javul, az implicit adósság nagy mértékben csökken. A másik hipotetikus reform, a törvényes nyugdíjkorhatár emelése minőségileg hasonló viselkedési reakciókat vált ki 11

Fehr, Kallweit, Kindermann [2010] a német nyugdíjrendszer 2007-es reformját szimulálja, melyben a törvényes nyugdíjkorhatár fokozatos, 65 évről 67 évre történő emeléséről döntöttek. A törvényes nyugdíjkorhatár előtti időszakban a munkavállalók itt is dönthetnek a nyugdíjba vonulás évérôl. Döntésük során Sanchez Martinhoz hasonlóan a nyugdíjba vonulás és a további munkavállalás állapotának értékét hasonlítják egymáshoz, de a nyugdíjba vonulás értékéhez egy további, nem megfigyelhető pszichológiai költség vagy haszon kapcsolódik, amely egy adott eloszlású valószínúségi változó. Az újítás eredményeként egy korosztály azonos képzettségú csoportjának tagjai sem egyszerre vonulnak nyugdíjba, szemben Sanchez Martinnal. A nyugdíjasok nyugdíjba vonulási kor szerinti empirikus eloszlását a kalibrált modell itt is jól visszaadja.

A 2007-es reform elótti nyugdíjrendszer fenntarthatatlanságára utal, hogy változtatások híján a nyugdíjkassza egyensúlyát biztosító járulékok kulcsának 19,9 \%-ról 28 \%-ra kell emelkednie 2040-ig, és emellett az időskori szegénység is jelentôsen nô. A törvénybe iktatott két évnyi nyugdíjkorhatár-emelés hosszú távon átlagosan mintegy tizenegy hónappal emeli az effektív nyugdíjkorhatárt. Elsôsorban ennek köszönhetően a nyugdíjrendszer egyensúlyát biztosító járulékkulcsnak is kevésbé kell emelkednie. A hosszabb munkapiaci pálya rövid- és közép távon csökkenti nagy mértékben a járulékokat, hosszú távon a hatást enyhítik a magasabb nyugdíjak.

A szerzôk a tényleges reformok mellett néhány érdekes hipotetikus reform hatását is megvizsgálták. Egy alapnyugdíj bevezetése a pontrendszerbe lazítja a munkapiaci teljesítmény és a nyugdíj közötti kapcsolatot, ami csökkenti a munkakínálatot és a megtakarításokat. Az alacsonyabb várt nyugdíj és az alacsonyabb megtakarítások miatt a nyugdíjba vonulás késôbbre csúszik, de ez sem semlegesíti a munkakínálat kezdeti visszaesését.

\footnotetext{
${ }^{11}$ Csak az új törvényes nyugdíjkorhatár mellett igényelhetô csökkentés nélkül nyugdíj, ezért a korhatár emelése az eredeti törvényes korhatár mellett például nyugdíjcsökkentést jelent.
} 
A másik hipotetikus reform a 60 év fölötti munkavállalók társadalombiztosítási hozzájárulásainak csökkentése az idősebb munkavállalók munkakínálatának ösztönzése érdekében. Az idôsebbek kisebb járulékkulcsából származó bevételkiesést a fiatalok járulékkulcsának növelésével pótolják. Az intézkedés természetesen tovább emeli az átlagos effektív nyugdíjkorhatárt és az aggregált foglalkoztatottságot is, de a kiesô bevételek miatt a fiatalok hozzájárulását kevésbé lehet csak csökkenteni, mint a korhatáremelést követôen.

A makroökonómiai modellek egy másik csoportja a nyugdíjba vonulás idôpontjának megválasztásán kívül megengedi a munkakínálati döntést az extenzív határon a teljes életpálya során. Erosa, Fuster, Kambourov [2011a] tanulmányában az öregségi- és rokkantnyugdíjrendszer és az adózás hatását vizsgálja az életciklusmunkakínálatra, annak is különösen az időskori szakaszára egy Auerbach-Kotlikoffféle általános egyensúlyi modellben. Eredményeik szerint az egyes országok eltérô rendszerei a modell alapján jól magyarázzák az életpálya-munkakínálat kései (50 év feletti) szakaszának eltéréseit. Az egyes alrendszerek közül különösen az öregségi nyugdíjrendszer hat erôsen a munkakínálatra.

Fehr, Halder, Jokisch [2003] a többek között a pótlási arányok fokozatos csökkentésérôl döntő Riester-reform után megvalósuló nyugdíjrendszer mellett nézi meg a demográfiai átmenetet hatásait a makrováltozókra. A modell többrégiós (Egyesült Államok, EU és Japán) kiterjesztéseinek (Fehr, Jokisch, Kotlikoff [2003]) modellstruktúrája szinte azonos, azonban a régiók közötti tókeáramlás lényegesen megváltoztathatja a fejlett országok tényezőárainak alakulását, így végsô soron a nyugdíjrendszer fenntarthatóságát is. Eredményeik szerint az adóemelések, amelyek a népesebb nyugdíjba vonuló korosztályok nyugdíjainak finanszírozásához szükségesek, az idősebb nepesség növekvő tôkekínálata ellenére tókehiányossá teszik a fejlett gazdaságokat, és így csökkentik a reálbéreket és növelik a kamatokat. A nyitottsággal járó tókeáramlás a (hatékonysági egységre jutó) reálbérek csökkenése miatt végsố soron súlyosbítja és nem enyhíti a költségvetésre nehezedő terheket. (Fehr, Jokisch, Kotlikoff [2005]) azonban rámutat arra, hogy Kína gazdaságának a figyelembe vétele drasztikusan változtat a helyzeten: bőséges tókekínálata hosszú távon (a technikai haladás üteménél jobban) növeli a reálbéreket, és ezáltal enyhíti 
4. fejezet: Demográfiai átmenet és parametrikus nyugdíjreformok hatása a gazdasági növekedésre és a nyugdíjrendszer fenntarthatóságára

a nyugdíjrendszer finanszírozási terheit. Ritkábban találkozhatunk az irodalomban kis, nyitott gazdasággal, és ha igen (például De la Croix, Pierrard, Sneesens [2012]), akkor általában a zárt gazdaság ellenpontjaként, tökéletesen elasztikus tôkekínálattal, így a tényezőárak végig változatlanok maradnak.

Magyarországon Simonovits [2003] több fontos kérdését (a nyugdíjak indexálásának változása, tôkefedezeti rendszerre való áttérés) modellezte a nyugdíjreformoknak az együttélő korosztályok modelljének segítségével, de a demográfiai folyamatok változásától közben eltekintett. Demográfiai átmenetet és együttélő korosztályokat egyaránt tartalmazó Simonovits [2009b] modellje a fejlett országok összessége szempontjából elfogadható paraméterek mellett illusztrálja, hogy a demográfiai átmenet során parametrikus nyugdíjreformok hogyan hatnak a nyugdíjrendszer fenntarthatóságát jellemzô mutatókra és az egyes generációk fogyasztására. A modellezési technika több lényeges újítást tartalmaz: az optimalizáló háztartások a fogyasztás relatív változását és nem a szintjét tartják fontosnak, a családméret korral változik, és az átmenet pályáit a szerzô a tökéletes előrelátás és naív várakozások mellett is megoldja. A munkakínálat azonban jelen tanulmánnyal ellentétben rögzített, és a demográfiai folyamatok nem hatnak vissza a reálbérek értékére.

\subsection{Demográfiai átmenet egy kis nyitott gazdaság OLG modelljében}

A továbbiakban felírjuk egy kis nyitott gazdaság OLG modelljét, melyben késóbb a demográfiai változásoknak és parametrikus nyugdíjreformoknak a hatását vizsgáljuk meg. A modellben a fogyasztás-megtakarítási döntés mellett a munkakínálat (az összes ledolgozott óra) is endogén, és a fogyasztó figyelembe veszi halandósági kockázatait és azt, hogy munkavállalóként nettó bérei meghatározzák késóbbi nyugdíját. 


\subsubsection{Demográfia}

A modell felírásában a $t$ index az évekre, $j$ pedig a szereplók korára utal. A gazdaságban minden $t$ idôszakban $J$ korosztály él együtt. A szereplốk maximális életkora $J$, de életük során (idôben változó) halandósági kockázattal szembesülnek: annak a valószínúsége a $t$ idôszakban, hogy a $j$ éves korukat megélik $\psi_{t, j}$. A továbbélési valószínúség a feltételes túlélési valószínűségek szorzata: $\psi_{t, j}=\prod_{i=1}^{j} s_{t+i-j, i}$. A legfiatalabb korosztály létszámát a termékenység, a migráció és a túlélési valószínúségek határozzák meg, melyeket együttesen a $\mu_{t}$ exogén változó tükröz. Ezek hatására a legfiatalabb korosztály létszáma $\mu_{t}$ ütemben nố a $t$ és $t-1$ idôszak között:

$$
N_{t, 1}=N_{t-1,1}\left(1+\mu_{t}\right) .
$$

Az idôsebb korosztályok létszámát a túlélési esélyek $\left(s_{t, j}\right)$ mellett a migrációs folyamatok $\left(m g_{t, j}\right)$ határozzák meg:

$$
N_{t, j}=N_{t-1, j-1} s_{t, j}+m g_{t, j} .
$$

A népesség teljes létszáma a $t$ idôszakban az egyes korosztályok létszámának az összege: $N_{t}=\sum_{j=1}^{J_{1}} N_{t, j}$. A későbbiekben feltételezem, hogy a bevándorló és az "őshonos" népesség viselkedése között nincs különbség.

\subsubsection{A háztartások döntési problémája}

A modellben a háztartás két életszakaszban maximalizálja az életpálya-hasznosságát, melynek során fogyasztási-megtakarítási és munkakínálati döntést hoz, majd egy mindenki számára egységes nyugdíjkorhatárt követôen felhagy a munkával, és korábbi teljesítménye alapján nyugdíjat kap. Döntései során figyelembe veszi halandósági kockázatait, és azt is, hogy késóbbi nyugdíjához hozzájárul a nettó munkajövedelmeivel. Termelékenységét egy életkortól függő exogén termelékenységi profil befolyásolja. Kezdô nyugdíja valorizált nettó jövedelmeinek konstans hányada, késôbbi nyugdíja pedig felerészt követi a gazdaság átlagos nettó kereseteinek növekedését. 
4. fejezet: Demográfiai átmenet és parametrikus nyugdíjreformok hatása a gazdasági növekedésre és a nyugdíjrendszer fenntarthatóságára

A munkakínálati (és fogyasztási) döntést hozó háztartások a vizsgált jelenség szempontjából releváns életpályáját két nagy szakaszra bontottuk:

1. Fiatalok: fogyasztási és munkakínálati döntéseket hoznak. Utóbbi döntéseik közvetlenül kihatnak a nyugdíjas évek alatti jövedelmeikre. Feltesszük, hogy a nyugdíj kezdô összegét ezen idôszak valorizált nettó béreinek az átlaga alapján határozzák meg, egy exogén helyettesítési ráta alapján. A fiatal periódusok száma $J_{1}$, azaz $1 \leq j \leq J_{1}$.

2. Nyugdíjasok: ezen időszak alatt nyugdíjat kapnak (nyugdíjindexálás), munkakínálati döntést nem hoznak, csak fogyasztási döntést. $J_{1}+1 \leq t \leq$ $J_{1}+J_{2}=J$.

\section{Az életpálya hasznossága}

A modellben döntést hozó háztartások az életpálya-hasznossági függvényüket maximalizálják:

$$
U_{t}=\sum_{j=1}^{J} \beta^{j-1} \psi_{t+j-1, j} u\left(c_{t+j-1, j}, l_{t+j-1, j}\right),
$$

ahol $\psi_{t, j}$ a túlélési valószínúség $\beta$ a türelmetlenségi paraméter. A $u(.,$.$) pillanatnyi$ hasznossági függvény a fogyasztás és a munka függvénye:

$$
u\left(c_{t, j}, l_{t, j}\right)=\ln c_{t, j}-\gamma \frac{l_{t, j}^{1+\xi}}{1+\xi}
$$

ahol $c_{t, j}$ a fogyasztás, $l_{t, j}$ a ledolgozott órák száma, $\gamma$ a fogyasztás és munka relatív súlyát, $\xi$ a munkakínálat Frisch-féle rugalmasságának a reciproka.

\section{Korlátok}

Termelékenység Az életpálya során a háztartások termelékenysége egy exogén pályának $\left(e_{j}\right)$ megfelelôen változik:

$$
e_{j}=e^{a_{0}+a_{1} j+a_{2} j^{2}} .
$$


A fiatalok költségvetési korlátja Egy j éves munkavállaló költségvetési korlátja a $t$ évben $\left(j \leq J_{1}\right)$ :

$$
a_{t+1, j+1}+c_{t, j}+\operatorname{Tax}_{t, j}=\left(1+r_{t}\right)\left(a_{t, j}+B e q_{t} / N_{t}\right)+w_{t} e_{j} l_{t, j}
$$

azaz az összes bérét $\left(w_{t} e_{j} l_{t, j}\right)$, felhalmozott vagyonát $\left(a_{t, j}\right)$, az örökségét $\left(B e q_{t} / N_{t}\right)$ és ezek kamatait $\left(r_{t}\left(a_{t, j}+B e q_{t} / N_{t}\right)\right)$ vagyon felhalmozására $\left(a_{t+1, j+1}\right)$, fogyasztásra $\left(c_{t, j}\right)$ és a nettó adók és járulékok befizetésére $\left(\operatorname{Tax}_{t, j}\right)$ fordítja. A vagyon $\left(a_{t, j}\right)$ államkötvényekból $\left(b_{t, j}^{g}\right)$, külföldi vagyonból $\left(b_{t, j}^{f}\right)$ és tókéból áll $\left(k_{t, j}\right)$ A nettó adók összetevői a fogyasztási adó $\left(\tau_{c, t} c_{t, j}\right)$, a tókejövedelemadó $\left(\tau_{k} r_{t} a_{t, j}\right)$, a munkajövedelemadó $\left(\tau_{l} w_{t} e_{j} l_{t, j}\right)$, a nyugdíjjárulék $\left(\tau_{b, t} w_{t} e_{j} l_{t, j}\right)$ és a transzferek $\left(z_{t, j}\right)$ :

$$
\operatorname{Tax}_{t, j}=\tau_{c, t} c_{t, j}+\tau_{k} r_{t}\left(a_{t, j}+B e q_{t} / N_{t}\right)+\left(\tau_{l}+\tau_{b, t}\right) w_{t} e_{t, j} l_{t, j}-z_{t, j}
$$

A nyugdíjasok költségvetési korlátja Egy $j$ éves fogyasztó költségvetési korlátja a $t$ évben, ha nyugdíjas $\left(j \geq J_{1}+1\right)$

$$
a_{t+1, j+1}+c_{t, j}+\operatorname{Tax}_{t, j}=\left(1+r_{t}\right)\left(a_{t, j}+B e q_{t} / N_{t}\right)+b_{t, j}
$$

azaz nyugdíjasként nyugdíját $\left(b_{t, j}\right)$, felhalmozott vagyonát $\left(a_{t, j}\right)$, az örökségét $\left(B e q_{t} / N_{t}\right)$ és ezek kamatait $\left(r_{t}\left(a_{t, j}+B e q_{t} / N_{t}\right)\right.$ vagyon felhalmozására $\left(a_{t+1, j+1}\right)$, fogyasztásra $\left(c_{t, j}\right)$ és a nettó adók $\left(\operatorname{Tax}_{t, j}\right)$ fordítja. Nyugdíjas korában nyugdíján felül nem kap egyéb transzfert, nem dolgozik $\left(l_{t, j}=0\right)$, és az adófizetési kötelezettségei is ennek megfelelően csökkennek:

$$
\operatorname{Tax}_{t, j}=\tau_{c, t} c_{t, j}+\tau_{k} r_{t}\left(a_{t, j}+B e q_{t} / N_{t}\right)
$$

Örökség A háztartásnak nincs induló vagyona $\left(a_{t, 1}=0\right)$, és nem is tervezi, hogy örökséget hagyjon hátra a $\left(a_{t+J, J+1}=0\right)$ a tervezési horizont végére. A legfeljebb $J$ idôs korban elhunyt szereplók vagyonát transzfer formájában egyenletesen

\footnotetext{
${ }^{12} \mathrm{Az}$ elsố kettô kamata egyaránt $r_{t}$, a tôke bérbeadásából a háztartás $r_{t}^{K}$ bérleti díjat kap, a tôke $\delta$ ütemben amortizálódik, és a tókefelhalmozást a szokásos $i_{t}=k_{t+1}-(1-\delta) k_{t}$ egyenlet határozza meg. Az optimális helyettesítés feltétele, hogy az eszközök (amortizáció utáni) hozama megegyezik, azaz $r_{t}=r_{t}^{K}-\delta$. A 4.8 egyenlet felírásánál már feltettük, hogy a feltétel teljesül.
} 
4. fejezet: Demográfiai átmenet és parametrikus nyugdíjreformok hatása a gazdasági növekedésre és a nyugdíjrendszer fenntarthatóságára

$\left(B e q_{t} / N_{t}\right)$ osztják szét a lakosság között. Ennek értéke:

$$
B e q_{t}=\sum_{j=1}^{J}\left(1-s_{t, j}\right) N_{t-1, j-1} a_{t, j} .
$$

\section{A nyugdíjak kiszámításának a módja}

Az induló nyugdíj értéke Az induló nyugdíj értékét $\left(b_{t+1, J_{1}+1}\right)$ a $t+1$ időszakban két tényezô szorzata adja. A két tényezô a nyugdíjbavonulást megelôzô $J_{1}$ periódus valorizált nettó munkajövedelmének átlaga $\left(\bar{W}_{t, J_{1}}\right)$ és a helyettesítési arány $(\alpha)$ :

$$
b_{t+1, J_{1}+1}=\alpha \bar{W}_{t, J_{1}} .
$$

A korábbi $J_{1}$ periódus nettó bérének valorizált átlaga:

$$
\bar{W}_{t, J_{1}}=\sum_{j=1}^{J_{1}}\left(1-\tau^{l}-\tau^{b}\right) G_{t+1, t-J_{1}+j} w_{t+j-J_{1}} e_{j} l_{t+j-J_{1}, j} / J_{1},
$$

ahol a nettó bérek átlagos növekedési tényezője (a munkajövedelem adókulcsának és a járulékkulcsnak a változatlanságát már figyelembe véve) a $t$ és a $t-1$ időszak között

$$
g_{t}=\frac{\sum_{j=1}^{J_{1}} w_{t} e_{j} l_{t, j} N_{t, j} / \sum_{j=1}^{J_{1}} N_{t, j}}{\sum_{j=1}^{J_{1}} w_{t-1} e_{j} l_{t-1, j} N_{t-1, j} / \sum_{j=1}^{J_{1}} N_{t-1, j}},
$$

a nettó bérek kumulált növekedési tényezője a $k$ és a $l-1$ idôszak között pedig $G_{k, l-1}=\prod_{s=l}^{s=k} g_{s}$

Ahhoz, hogy a háztartások munkakínálati döntésük során figyelembe tudják venni annak a késóbbi kezdő nyugdíjukra gyakorolt jótékony hatását, az összefüggést egy "nyugdíj-felhalmozási egyenletté" alakítottuk. Az összefüggés azt mutatja meg, hogy aktív életszakaszukban az egyének időarányosan mennyivel gyarapítják késôbbi nyugdíjuk kezdőértékét $\left(1 \leq j \leq J_{1}\right)$ :

$$
b_{t+1, j+1}^{J_{1}+1}=g_{t+1}\left[b_{t, j}^{J_{1}+1}+\frac{\alpha\left(1-\tau_{l}-\tau_{b}\right) w_{t} e_{t, j} l_{t, j}}{J_{1}}\right] .
$$


A nyugdíjak indexálása A nyugdíjindexálás formulája szerint a nyugdíjak a reálbérek növekedési ütemét követik az indexálásnak megfelelô mértékben $\left(J_{1}+1 \leq j \leq J\right)$ :

$$
b_{t, j}=b_{t-j+J_{1}+1, J_{1}+1} G_{t, t-j+J_{1}+1}^{1-v},
$$

ahol az inflációt követik a nyugdíjak, ha $v=1$, a bérek növekedését, ha $v=0$, és svájci indexálást használnak, ha $v=0,5$. A nyugdíjas évek elôtt $\left(j \leq J_{1}\right)$ a nyugdíjak értéke 0 .

\subsubsection{A háztartások problémájának a megoldása}

A háztartások problémájánk a megoldását a F.2. Függelékben ismertetjük részletesen 13

Amennyiben fiatal korban $\left(1 \leq j \leq J_{1}\right)$ a háztartás nem venné figyelembe, hogy a nettó bérei a késóbbi nyugdíjának az alapját képezik, akkor munkakínálati döntését egy hagyományos összefüggés vezérelné:

$$
l_{t, j}=\left(\frac{1-\tau_{l}-\tau_{b, t}}{\left(1+\tau_{c, t}\right) \gamma c_{t, j}} w_{t} e_{j}\right)^{1 / \xi},
$$

vagyis a háztartás a magasabb termelékenységgel és nettó bérrel, illetve alacsonyabb fogyasztással (és magasabb határhaszonnal) jellemezhetô idôszakok felé csoportosítaná át a munkájukat.

De mitől függ a fogyasztás pályája?

A munkakínálati függvényt intertemporális összefüggéssé alakíthatjuk, ha felhasználjuk a fogyasztás optimális idóbeli pályáját leíró Euler-egyenletet:

$$
\frac{1}{c_{t, j}\left(1+\tau_{c, t}\right)} \psi_{j, t+j-1}=\left[\beta\left(1+r_{t+1}\left(1-\tau_{k}\right)\right)\right] \psi_{j+1, t+j} \frac{1}{c_{t+1, j+1}\left(1+\tau_{c, t+1}\right)} .
$$

\footnotetext{
${ }^{13} \mathrm{~A} 3$. és a 4 fejezetben a háztartások feladata között kis eltérések vannak. A Függelékben egy olyan feladatot oldunk meg, amely speciális esetként tartalmazza mindkét fejezet problémáját. A jelen fejezethez tartozó megoldás $\sigma=1$ behelyettesítéssel adódik.
} 
4. fejezet: Demográfiai átmenet és parametrikus nyugdíjreformok hatása a gazdasági növekedésre és a nyugdíjrendszer fenntarthatóságára

Az összefüggés szerint akkor lesz meredekebb a fogyasztás pályája, tehát korral akkor nó jobban a fogyasztás, ha a háztartás türelmesebb, magasabb a kamatláb vagy a későbbi időszak megélésének a feltételes valószínúsége, illetve a fogyasztási adó kulcsa csökkenni fog.

Az Euler-egyenletből és a korábbi munkakínálati összefüggésből meghatározható a munkakínálat optimális idóbeli pályája:

$$
\frac{l_{t, j}}{l_{t+1, j+1}}=\left\{\left(1+r_{t+1}\left(1-\tau_{k}\right)\right) \frac{\beta \psi_{j+1, t+j} w_{t} e_{j}}{\psi_{j, t+j-1} w_{t+1} e_{j+1}}\right\}^{1 / \xi}
$$

A munkakínálat korral tehát akkor csökken, ha csökken a termelékenység, csökkennek a bérek, illetve a fogyasztók türelmesek a piaci kamatlábhoz képest. A feltételes túlélési valószínúségek $\left(\psi_{j+1, t+j} / \psi_{j, t+j-1}\right)$ javulása fiatalabb kor felé rendezi át a munkakínálatot. $1 / \xi$ mutatja meg, hogy az előbbi tényezôk eredôjére milyen rugalmasan reagál a munkakínálat.

Amennyiben azt is figyelembe veszi a háztartás, hogy az ún. "nyugdíjfelhalmozási egyenlet" szerint a nettó keresetek a késôbbi nyugdíj kezdőértékét gyarapítják, a munkakínálatnak további ösztönzője is jelentkezik (a jobboldali kifejezés második $\operatorname{tagja):~}$

$$
l_{t+j-1, j}=\left[\frac{w_{t+j-1} e_{j}}{\gamma}\left(\frac{1-\tau_{l}-\tau_{b}}{1+\tau_{c, t+j-1}} c_{t+j-1, j}^{-1}+\beta^{J_{1}-j-1} \frac{\psi_{t+J_{1}, J_{1}+1}}{\psi_{t+j-1, j}} \frac{G_{t+J_{1}, t+j-1} \alpha\left(1-\tau_{l}-\tau_{b}\right) c_{t+J_{1}, J_{1}+1}^{-1}}{\left(1+\tau_{c, t+J_{1}}\right) J_{1}}\right)\right]^{1 / \xi} .
$$

Az összefüggés második tagjából megállípítható, hogy ez az ösztönző hatás erősebb, ha magasabb a várható átlagos reálbérnövekedés a nyugdíjig hátralévô években $(G)$ vagy magasabb a helyettesítési ráta $(\alpha)$, ha rövidebb az átlagolási idôszak $\left(J_{1}\right)$, kisebb a munkajövedelem-adó $\left(\tau_{l}\right)$ és a nyugdíjjárulék $\left(\tau_{b}\right)$ kulcsa vagy magasabb a fogyasztás határhaszna (alacsonyabb a fogyasztás) a nyugdíjba vonulás idején $\left(c_{J_{1}+1}^{-1}\right)$. Az ösztönzô erố a nyugdíjba vonulás időpontjától távolodva gyengül a szereplők türelmetlensége $\left(\beta^{J_{1}-j-1}\right)$ és a nyugdíjazás megélésének alacsonyabb feltételes valószínúsége $\left(\psi_{J_{1}+1} / \psi_{j}\right)$ miatt.

Egy további optimális viselkedést leíró összefüggés szerint amortizáció után a tókének, a belföldi és külföldi vagyoneszközöknek a hozama meg kell hogy egyezzen 
(a kifejezés a külső adósságráta által meghatározott (lásd később) kamatláb mellett egy tökéletesen rugalmas inverz tôkekínálati függvény):

$$
r_{t+1}^{K}=r_{t+1}+\delta
$$

A háztartás optimális döntésénél az ún. vagyonhatás érvényesülését az intertemporális költségvetési korlát biztosítja.

$\sum_{j=1}^{J} R_{t, t+j-1}\left(1+\tau_{c, t+j-1}\right) c_{t+j-1, j}=\sum_{j=1}^{J} R_{t+j-1, j}\left(\left(1-\tau_{l}-\tau_{b}\right) w_{t} e_{t+j-1, j} l_{t+j-1, j}+b_{t+j-1, j}\right)$

ahol a $t$ és az $i$ idôszak közötti diszkonttényezô

$$
R_{t, i}=\left\{\begin{array}{c}
\prod_{z=t+1}^{i}\left(1+\left(1-\tau_{k}\right) r_{z}\right)^{-1}, \text { ha } t<i \\
1, \text { ha } t=i
\end{array}\right\}
$$

\subsubsection{Vállalatok}

A gazdaságban sok azonos, az output- és inputpiacon egyaránt versenyzố vállalat múködik, a számuk egyre normált. A reprezentatív vállalat technológiáját CobbDouglas típusú termelési függvény jellemzi

$$
Y_{t}=K_{t}^{\varepsilon}\left(A_{t} L_{t}\right)^{1-\varepsilon}
$$

ahol $L_{t}$ az effektív munkaórák számát, $K_{t}$ az aggregált tôkeállományt jelöli, $A_{t}$ a teljes tényezôtermelékenység, $\varepsilon$ pedig a kibocsátás tőke szerinti rugalmassága $(0<\varepsilon<1)$.

A munkakiterjesztő technikai haladás növekedési üteme $\lambda$ :

$$
A_{t+1}=(1+\lambda) A_{t} .
$$


4. fejezet: Demográfiai átmenet és parametrikus nyugdíjreformok hatása a gazdasági növekedésre és a nyugdíjrendszer fenntarthatóságára

\section{A vállalatok problémájának a megoldása}

A vállalat a termelés során számára adott reál bérleti díj $\left(r_{t}^{K}\right)$ mellett vesz bérbe a háztartástól tôkét és adott reálbér $\left(w_{t}\right)$ mellett alkalmazza a munkásokat. A vállalat profimamaximalizálási feladatának megoldásából kapjuk a vállalat munkaés tôkekeresleti függvényeit:

$$
\begin{aligned}
\varepsilon\left[\frac{K_{t}}{A_{t} L_{t}}\right]^{\varepsilon-1} & =r_{t}^{K} \\
(1-\varepsilon)\left[\frac{K_{t}}{A_{t} L_{t}}\right]^{\varepsilon} A_{t} & =w_{t} .
\end{aligned}
$$

\subsubsection{Az állam költségvetése}

Az állam minden időszakban nettó adóbevételeibö $14\left(\sum_{j=1}^{J} \operatorname{Tax}_{t, j} N_{t, j}\right)$, az újonnan kibocsátott egyperiódusú kötvényeiból $\left(B_{t+1}^{g}\right)$ jut bevételhez, amit kormányzati vásárlásokra $\left(G o v_{t}\right)$, az államadósság és kamatainak visszafizetésére $\left(\left(1+r_{t}\right) B_{t}^{g}\right)$ és nyugdíjkiadásaira fordít $\left(P_{t}\right)$ :

$$
\operatorname{Gov}_{t}+\left(1+r_{t}\right) B_{t}^{g}+P_{t}=\sum_{j=1}^{J} \operatorname{Tax}_{t, j} N_{t, j}+B_{t+1}^{g}
$$

A nettó adó- és járulékbevételek összetevőit a 4.11 egyenlet mutatja be. Az állam minden évben a GDP gov százalékát fordítja kormányzati vásárlásra. A kormány a fogyasztási adók kulcsát minden időszakban úgy igazítja, hogy a GDParányos államadósság konstans szinten maradjon.

\section{A társadalombiztosítási nyugdíjrendszer}

A társadalombiztosítási nyugdíjrendszer bevételeit a járulékok, kiadásait az öregségi nyugdíjak képezik a modellben. Egy j éves munkavállaló által befizetett járulék

\footnotetext{
${ }^{14} \mathrm{~A}$ nettó adóbevételek tartalmazzák a nyugdíjkassza összes járulékbevételét is.
} 
értéke a $t$ évben a járulékkulcs $\left(\tau_{b}\right)$ és az összes bér $\left(w_{t} e_{t, j} l_{t, j}\right)$ szorzata, a nyugdíjrendszer összes járulékbevétele pedig az összes munkavállaló járulékbefizetéseinek az összege: $T_{t}^{b}=\sum_{j=1}^{J_{1}} \tau_{b} w_{t} e_{t, j} l_{t, j} N_{t, j}$. A nyugdíjrendszer által kifizetett összes nyugdíj a $t$ évben: $P_{t}=\sum_{j=J_{1}+1}^{J} b_{t, j} N_{t, j}$.

A nyugdíjrendszer fenntarthatóságát, a terhet, melyet a költségvetés számára okoz, a nyugdíjkassza jövedelemarányos egyenlegeinek alakulásával mérjük:

$$
\frac{S_{t}^{b}}{Y_{t}}=\frac{T_{t}^{b}-P_{t}}{Y_{t}}
$$

\subsubsection{Egyensúlyi feltételek}

Általános egyensúly a $t$ időszakban akkor jön létre, ha az egyes piacokon olyan relatív árak alakulnak ki, hogy a szereplók adott árak mellett hozott optimális viselkedése mellett a piacok megtisztulnak, azaz a kereslet megegyezik a kínálattal.

Az árupiacon a vállalatok kibocsátása megegyezik a belföldi kereslet és a nettó export összegével:

$$
C_{t}+I_{t}+G_{0 v_{t}}+N X_{t}=Y_{t}
$$

ahol $C_{t}=\sum_{j=1}^{J} c_{t, j} N_{t, j}$ a háztartások aggregált fogyasztása, $I_{t}$ az aggregált beruházás, $N X_{t}$ pedig a nettó export. Az aggregált beruházások a tókefelhalmozási egyenleten keresztül határozzák meg a tôkeállomány dinamikáját

$$
K_{t+1}=I_{t}+(1-\delta) K_{t}
$$

ahol $\delta$ az amortizációs ráta. A nettó export pedig az alábbi egyenleten keresztül hat a külföldi vagyon $\left(B_{t}^{f}\right)$ alakulására:

$$
B_{t+1}^{f}=N X_{t}+\left(1+r_{t}\right) B_{t}^{f}
$$

azaz a küföldi vagyon változása a nettó export és a külföldi kamatjövedelmek összege. A munkapiacon a munkások teljes (effektív) munkakínálata megegyezik a vál- 
4. fejezet: Demográfiai átmenet és parametrikus nyugdíjreformok hatása a gazdasági növekedésre és a nyugdíjrendszer fenntarthatóságára

lalatok munkakeresletével:

$$
L_{t}^{D}=\left[\frac{(1-\varepsilon)}{w_{t}} A_{t}\right]^{1 / \varepsilon} \frac{K_{t}}{A_{t}}=\sum_{j=1}^{J} e_{j} l_{t, j} N_{t, j} .
$$

A tôkepiacon a vállalatok tőkekereslete megegyezik a fogyasztók tôkekínálatával:

$$
\varepsilon\left[\frac{K_{t}}{A_{t} L_{t}}\right]^{\varepsilon-1}=r_{t}^{K}=r_{t}+\delta
$$

A kamatláb a jövedelemarányos külső adósságban $\left(-B_{t+1}^{f} / Y_{t}\right)$ növekszik az exogén világpiaci kamatláb $\left(r^{*}\right)$ felett:

$$
r_{t+1}=r^{*}+\left(e^{-\omega B_{t+1}^{f} / Y_{t}}-1\right)
$$

ahol a kamatláb rugalmasságát a jövedelemarányos külső adósság szerint az $\omega$ paraméter mutatja. A vagyoneszközök piacán az aggregált tókeállomány $\left(K_{t+1}\right)$, államadósság $\left(B_{t+1}^{g}\right)$ és külföldi vagyon $\left(B_{t+1}^{f}\right)$ megegyezik a háztartások aggregált vagyonával $\left(\right.$ Asset $\left._{t+1}=\sum_{j=J}^{J} a_{t+1, j+1} N_{t, j}\right)$ :

$$
\text { Asset }_{t+1}=K_{t+1}+B_{t+1}^{g}+B_{t+1}^{f} .
$$

\subsubsection{A modell megoldása}

A kis nyitott gazdaság modelljének megoldásához minden $t$ időszakra meg kell adni a gazdaság egyéni változóinak, reálárainak és aggregált változóinak az értékét, melyekre teljesülnek az előzô részben leírt egyensúlyi feltételek. A modell megoldása során a gazdaság egy induló stacionárius állapotból a távoli jövôben egy záró stacionárius állapotba érkezik, a kettő között pedig a demográfiai átmenet során az átmeneti pályán halad. A gazdaság stacionárius állapotában állandó a népesség növekedési üteme $\left(\mu_{t}\right)$ és minden korosztály továbbélési valószínúsége is $\left(\psi_{t, j}\right)$. A technológiai exogén bơvülése miatt az egyensúlyi növekedési pálya mentén a legtöbb endogén változó értéke nem konstans, ezért normáltuk óket. Belátható, hogy az egyensúlyi növekedési pályán az aggregált változók, a reálárak és az egyéni vál- 
tozók növekedési üteme $\lambda \cdot \sqrt{15}$ zért a fajlagos változókat az eredeti változók $\widetilde{x_{t}}=\frac{x_{t}}{A_{t}}$ átalakításaként állítottuk elő, hogy az így létrehozott fajlagos változóknak már meg tudjuk határozni az állandósult állapotát. Az egyes korosztályok munkamennyisége, a tôke bérleti díja és a reálkamatláb az egyensúlyi növekedési pálya mentén nem változik, ezért ezeket a változókat nem normáltuk. A normált egyenleteket, melyeknek idôtól független, állandósult állapotai a gazdaság stacionárius állapotát adják meg, a F.3. Függelékben mutatjuk be. Az induló stacionárius állapotból a záró stacionárius állapotig a gazdaság dinamikáját a Matlab Dynare kiegészítő programcsomagjának segítségével oldottuk meg, amely minden egyes időszakra a gazdaságot leíró szimultán egyenletrendszer megoldását a Newton-módszerrel kereste meg.

\subsubsection{A paraméterek megválasztása és a gazdaság 2006-2010- es állapota}

A modell paramétereinek jelentős részét a magyar gazdaság és társadalom átlagos adatai alapján próbáltuk meghatározni, a paraméterek további részének értékét az irodalomban szokásásosan felvett értéktartományon belül állítottuk be.

A modellben az egyes periódusok a valóság ötéves időszakainak felelnek meg. Csak a legalább 26 éves háztartások hoznak döntést, akik maximálisan 115 éves korukig élnek, így $j=1,2, \ldots, J=18$. A szimuláció hossza 60 időszak, és 1950-tôl 2250-ig tart. A tanulmány a 2006-10 és 2066-70 közötti időszak eseményeit igyekszik bemutatni, az ennél korábbi évekre a gazdaság endogén állapotváltozóinak kialakulásához van szükség, a 2070 utáni időszakokra pedig azért, hogy a gazdaságnak legyen "ideje" eljutni az új stacionárius állapotáig. A populáció nagyságát, eloszlását és a túlélési valószínúségeket 2010-ig a Human Mortality Database [2014] alapján határoztuk meg, ezt követően pedig Hablicsek [2010] előreszámításait vettük alapul. A migrációs értékeket úgy állítottuk be, hogy az egyes korosztályok

\footnotetext{
${ }^{15}$ A legfiatalabb korosztály növekedési üteme az induló és a záró állandósult állapotban 0, ezért a népességgel való normálástól el lehetett tekinteni. A vizsgált idôszaktól mindkettô kellôen távol van, ezért a feltevés nem befolyásolja érdemben a késóbb kiemelésre kerülő idôszak eredményeit.
} 
4. fejezet: Demográfiai átmenet és parametrikus nyugdíjreformok hatása a gazdasági növekedésre és a nyugdíjrendszer fenntarthatóságára

létszáma megfelejen a tényadatoknak, illetve az előreszámításoknak. Mivel a modellben 26 évnél fiatalabb szereplók nem szerepelnek, ezért a 26-30 éves korosztály továbbélési valószínúsége 1 ; minden termelékenységi, migrációs és halandósági változás, amely 26-30 éves kor elôtt jelentkezik, a modellben a legfiatalabb korosztály létszámának változásában tükröződik.

A népesség korosztályok szerinti megoszlását a 2006-10-es és a 2066-70-es időszakban a 4.5. ábra mutatja. A 26-60 évesekre jutó 60 évnél idősebbek száma a 2006-10-es 43,1 \%-ról 2066-70-re 99,94 \%-ra nô. Az életszakasz elején (26 évesen) várható életkor így a modell 2006-2010-es időszakában 76,99 év, amely 2066-70-re 89,21 évre nô. 60 éves nyugdíjkorhatár mellett a nyugdíjazáskor várható életkor 2006-10-ben 87,58 év, amely 2066-70-re 92,92 évre emelkedik.

4.5. ábra. A népesség megoszlása az egyes korosztályok között a 2006-10-es és a 2066-70-es időszakában
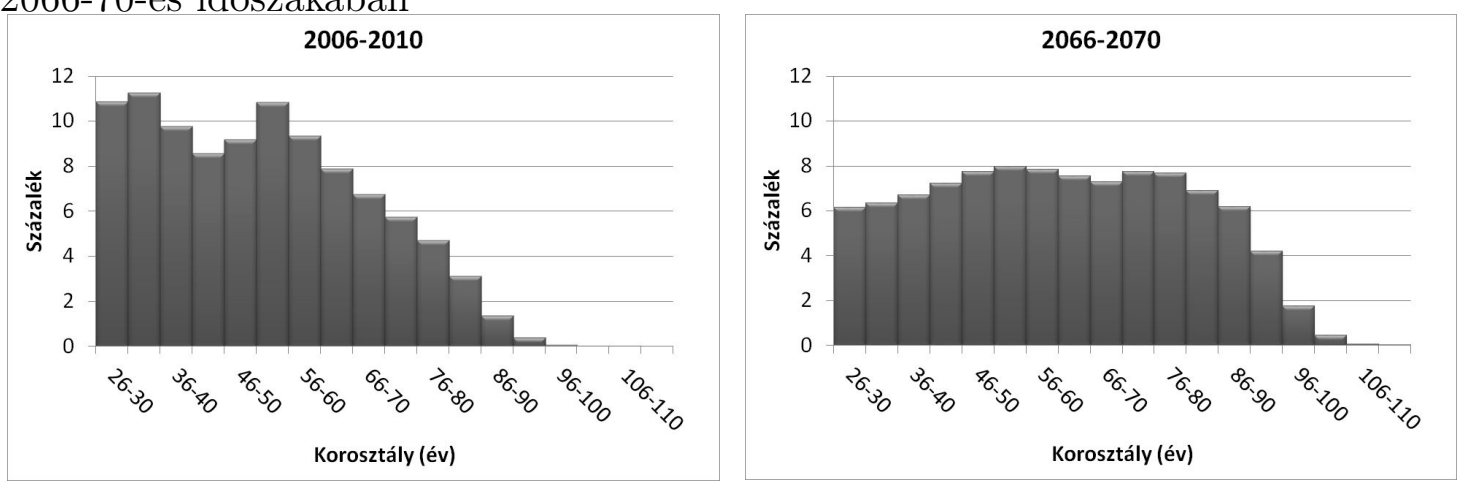

Az Eurostat méréseire támaszkodtunk (Eurostat [2012]) a munkajövedelem, a fogyasztás és a tókejövelem implicit adókulcsainak és a nyugdíjjárulékok implicit kulcsainak a kalibrálásánál. Az alkalmazott kulcsok a 2000 és 2009 közötti implicit ráták mértani átlagai. A munkát terhelő adókulcsot úgy osztottuk szét a munkajövedelemadók és nyugdíjjárulékok között, hogy a társadalombiztosítási nyugdíjrendszer a szimuláció 2006-2010-es időszakában közel kiegyensúlyozott legyen.

Az öregségi nyugdíjrendszerben az átlagos helyettesítési ráta alapesetben 75 százalék, a mindenki számára kötelezô nyugdíjkorhatár 60 év (a 7. időszak vége). A nyugdíjak indexálása felerészt követi a nettó reálbérek növekedését, a nyugdíjak 
kiszámításánál a nyugdíjazás előtti 7 időszak valorizált átlagos nettó munkajövedelmét veszik figyelembe.

A háztartások preferenciáit leíró paraméterek közül a munka súlya a pillanatnyi hasznosságban $(\gamma)$ és a munkakínálat rugalmasságának reciproka $(\xi)$ Major és Varga [2013] cikkéból származnak ${ }^{16}$. A termelékenységi profil paraméterei lehetôvé teszik, hogy a munkaórák kor szerinti alakulása közel essen a magyar férfiak 1999 és 2009 közötti átlagos munkaóra korprofiljához.

Modellünkben $\lambda$ a technikai haladás ütemét mutatja, amely az egyensúlyi növekedési pályán megegyezik az egy főre jutó reál GDP növekedési ütemével. Az 1999-2009 időszakban a magyar gazdaságban a reál GDP növekedési üteme 2,35 százalék volt, aminek az ötévesített változatát használtunk. A kormányzati vásárlások a GDP 19\%-át teszik ki, ami a végsố kormányzati fogyasztásnak az átlagos GDP-arányos értéke 1999 és 2009 között. A nyugdíjkiadásokon felüli transzferkiadások GDP-arányos értéke 10 \% körül alakul, a GDP-arányos államadósság pedig a modell 2006-10-es időszakában 62,5\%, amely szintén az 1999 és 2009 közötti idôszak átlagos értéke. 2006-10-ben a modell társadalombiztosítási nyugdíjrendszerének egyenlege csaknem teljesen kiegyensúlyozott, a GDP 11,32 \%-át kitevố nyugdíjkiadásokat fedezik a nyugdíjjárulékból származó bevételek.

A világpiaci (ötéves) reálkamatláb 10 százalékos, a kockázati prémium GDParányos külső vagyon szerinti rugalmasságát úgy adtam meg, hogy a külső adósság az éves GDP-nek 90 \%-a körül alakuljon 2006-10-ben, az azt megelőző évtized nettó nemzetközi befektetési pozíciójának átlagához igazodva. A kalibrált 2,1-es érték szerint az ötéves kamatprémium 2,1 \%-kal nő, ha a külsố adósságráta az ötéves GDP 1 \%-kával emelkedik. Ez egyenértékű azzal, hogy az egyéves GDP 1\%-kának megfelelô adósságnövekedés az éves kamatprémiumot körülbelül 0.084 \%-kal emeli. Az eltérô függvényforma miatt a kalibrált paraméterértékünket nehéz összehasonlítani a korábbi tanulmányok igen nagy terjedelmen belül szóródó értékeivel (pl. Schmitt-Grohé-Uribe [2003], Schmitt-Grohé-Uribe [2015] 4. táblázata).

\footnotetext{
${ }^{16}$ A 3 fejezetben írtunk arról, hogy a munkakínálati rugalmasság választott értéke hogyan viszonyul a szakirodalomban található értékekhez.
} 
4. fejezet: Demográfiai átmenet és parametrikus nyugdíjreformok hatása a gazdasági növekedésre és a nyugdíjrendszer fenntarthatóságára

A reprezentatív vállalat termelési függvényében a kibocsátás tôke szerinti rugalmassága 0,33, az ötéves amortizációs ráta pedig 20\%-os, melynek köszönhetően 2010-ben az éves $K / Y$ arány 2,19. A paraméter értékeit az 4.1. táblázat tartalmazza.

4.1. táblázat. A modell paraméterei az alapváltozatban

\begin{tabular}{|l|r|}
\hline Paraméter neve & Param. értéke \\
\hline \hline diszkont tényezó́ & $\beta=0.81$ \\
a munka relatív súlya a hasznosságban & $\gamma=0.559$ \\
a munkakínálat rugalmasságának re- & $\xi=0.765$ \\
ciproka & \\
fogyasztás adókulcsa & $\tau_{c}=0.263$ \\
tôkejövedelem adókulcsa & $\tau_{k}=0.183$ \\
társadalombiztosítási hozzájárulás kul- & $\tau_{b}=0.159$ \\
csa & \\
munkajövedelem adókulcsa & $\tau_{l}=0.243$ \\
átlagos helyettesítési ráta & $\alpha=0.75$ \\
nyugdíjkorhatár & $J_{1}=7$ \\
nyugdíjas évek max. száma & $J 2=11$ \\
indexálási paraméter & $v=0.5$ \\
termelékenységi paraméterek & $a^{0}=0.000$ \\
& $a^{1}=0.194$ \\
& $a^{2}=-0.021$ \\
a világpiaci reálkamatláb & $r^{*}=0.1$ \\
a technikai haladás üteme & $\lambda=0.123$ \\
a kamatprémium rugalmassági paramé- & $\omega=2.1$ \\
tere & \\
a kormányzati vásárlások aránya a & \\
GDP-ben & \\
a kibocsátás tóke szerinti rugalmassága & \\
az amortizációs ráta & \\
\hline \hline
\end{tabular}




\subsubsection{Szimuláció}

\section{A demográfiai átmenet hatása a makrováltozók értékére és a nyugdíj- rendszer egyenlegére}

A szimuláció szerint 2006-10 és 2066-70 között az idôsödő társadalomban a 100 2660 évesre jutó idősek száma 43 főrôl 100 fôre emelkedik (4.6. ábra). A társadalom szerkezeti átalakulása mechanikusan, a viselkedési reakciók nélkül is megváltoztatja az egy fốre jutó makrováltozók pályáját, a háztartások viselkedésének megváltozása azonban lényegesen módosítja óket.

4.6. ábra. A 26-60 évesekre jutó 60 évnél idôsebbek száma 2006-10 és 2066-70 között

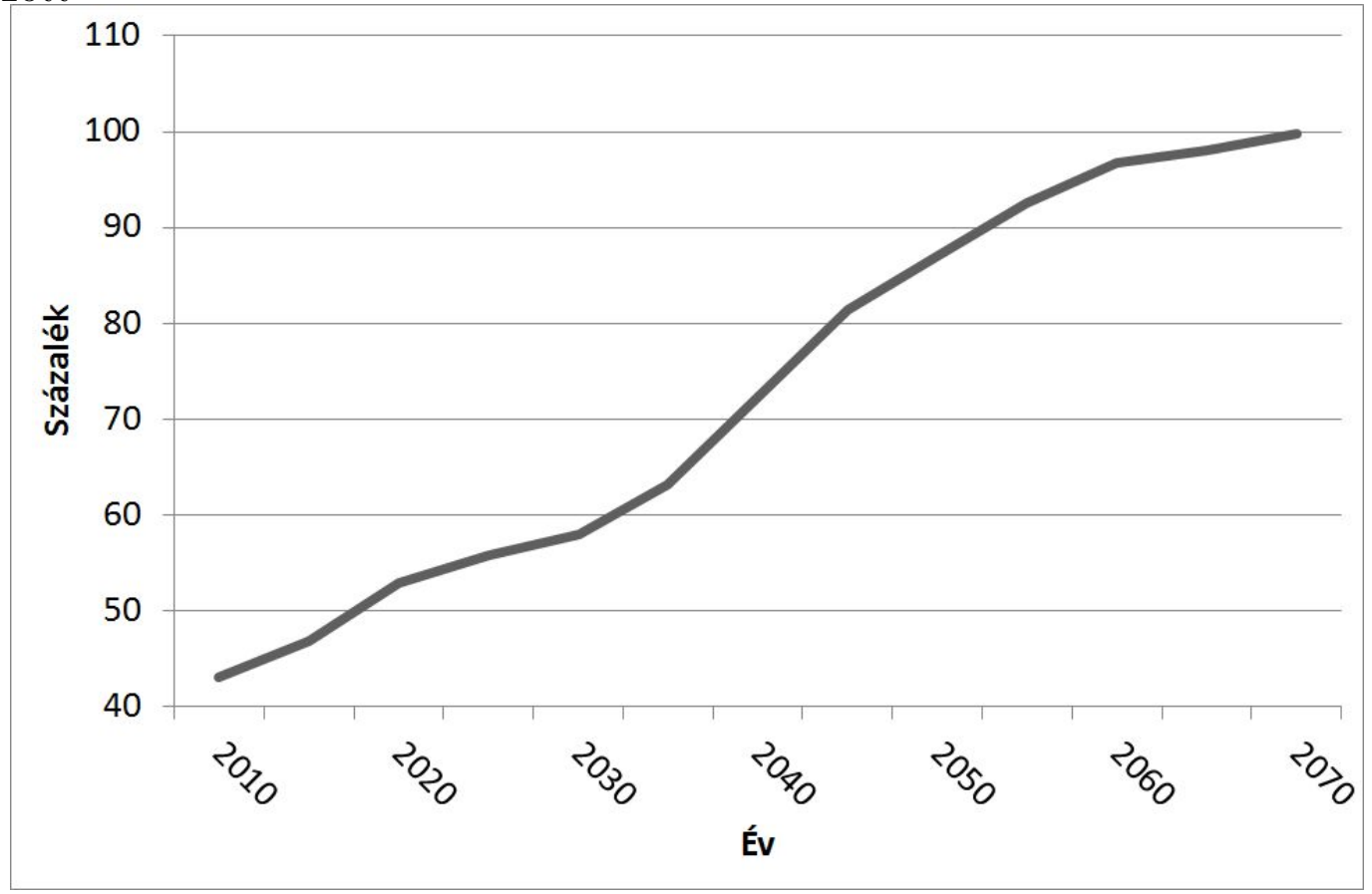

A neoklasszikus növekedési modellben a hatékony főre jutó GDP 19,98 \%-al csökken 2066-2070-re a 2006-2010-es időszakhoz képest, ami azt jelenti, hogy az egy före jutó GDP a periódus végére ennyivel marad el attól a szinttól, amit az évi 2,35\%-os technikai haladás tett volna lehetővé (az egy főre jutó GDP nem a 
4. fejezet: Demográfiai átmenet és parametrikus nyugdíjreformok hatása a gazdasági növekedésre és a nyugdíjrendszer fenntarthatóságára

négyszeresére, hanem "csak" a 3,26-szorosára emelkedik). A demográfiai átmenet hatására az egy fơre jutó effektív munkaórák száma ennél jobban, a hatékony főre jutó tôkeállomány kevésbé marad el a technikai fejlődés által lehetôvé tett szinttôl, mivel a háztartások a csak kevéssé visszaesó hatékony fơre jutó vagyonukból több beruházást tudnak finanszírozni.

De milyen tényezók állnak az output és a termelési tényezők változása mögött?

Az egy fớre jutó effektív munkakínálat $\left(L_{t}\right)$ 23,32 \%-kal csökken (4.7. ábra) a demográfiai átmenet során. ${ }^{17}$ Egy egyszerú dekompozíciós eljárássa ${ }^{18}$ az effektív munkakínálat csökkenése felbontható a munkaképes korú népesség arányának és szerkezetének változására, illetve az egyes korosztályok munkakínálatának változására. Pusztán a 60 év alatti népesség fogyása $\left(\Delta n_{60}\right)$ 27,56 \%-kal, a munkaképes korú népesség szerkezetében az alacsonyabb effektív munkakínálatú idősebb korosztályoknak súlyának emelkedése $(\Delta n)$ további 1,93\%-kal csökkentené az egy fốre jutó effektív munkakínálatot (4.2. táblázat). A teljes hatás $(\Sigma)$ azonban enyhébb az elôzô két tényezôból adódó mintegy 30 \%-os csökkenésnél az egyes korosztályok munkakínálati reakciójának $(\Delta x)$ köszönetôen, ami a dekompozíció szerint minden egyéb tényező változatlansága mellett 6,17 \%-kal növelte volna az effektív munkakínálatot. A 35 év alattiaktól eltekintve mindenki több effektív órát dolgozik.

4.2. táblázat. A hatékony főre jutó aggregált változók 2006-10 és 2066-70 közötti változásának dekompozíciója (\%-os változás)

\begin{tabular}{|l|ccc|}
\hline \hline & $L / N$ & $C / N$ & Asset $/ N$ \\
\hline$\Delta x$ & 6,17 & $-7,86$ & 18,96 \\
$\Delta n$ & $-1,93$ & $-7,42$ & $-25,10$ \\
$\Delta n_{60}$ & $-27,56$ & - & - \\
\hline$\Sigma$ & $-23,32$ & $-15,28$ & $-6,14$ \\
\hline \hline
\end{tabular}

\footnotetext{
${ }^{17}$ A teljes, hatékony munkaórák száma $\left(A_{t} L_{t}\right)$ a munkakiterjesztő technikai haladás miatt tehát 23,32 \%-kal marad el 2066-70-re attól a szinttól, amit a technikai haladás megendegett volna.

${ }^{18} \mathrm{~A}$ dekompozíciós módszert a F.4. Függelékben mutatom be.
} 
Az egy fơre jutó effektív munkaórák alacsonyabb száma ceteris paribus relatíve bőségessé teszi a hatékony főre jutó tôke mennyiségét, ez pedig csökkenti a tôke határtermékét, a vállalatok tôkekeresletét, ezért nem bôvítik úgy a tôkeállományt, ahogy a technikai haladás indokolná. A fajlagos beruházások csökkenése a folyó fizetési mérleg egyenlegét növeli és csökkenti a külsô adósságot. Ez azonban nem feltétlenül csökkenti a kockázati prémiumot, hiszen a fajlagos tôke és effektív munka csökkenése a fajlagos GDP-t is mérsékli, így a külsố adósságráta változása nem egyértelmú. A GDP-arányos külsố adósság csökkenését és ezzel a kamatok mérséklődését ezért végső soron a háztartások megtakarítási-vagyonfelhalmozási viselkedése határozza meg.

A hatékony fôre jutó fogyasztást a modellben a munkakínálathoz hasonlóan a demográfiai átalakulások közvetlenül és közvetve is érintik. A hatékony fớre jutó fogyasztás 15,28 \%-os csökkenéséból (4.2 táblázat) 7,86 \% az egyes korosztályok egy főre jutó fogyasztásának mérséklődése (80 év alatt minden korcsoportban csökkent az egy főre jutó hatékony fogyasztás), 7,42 \% pedig a népesség alacsonyabb fogyasztású csoportok felé történô átrendeződése miatt következett be (a 65 év alatti magasabb fogyasztású csoportok mindegyikének csökkent az aránya). 
4. fejezet: Demográfiai átmenet és parametrikus nyugdíjreformok hatása a gazdasági növekedésre és a nyugdíjrendszer fenntarthatóságára

4.7. ábra. A demográfiai átmenet hatása a makrováltozókra 2006-10 és 2066-70 között (1.)
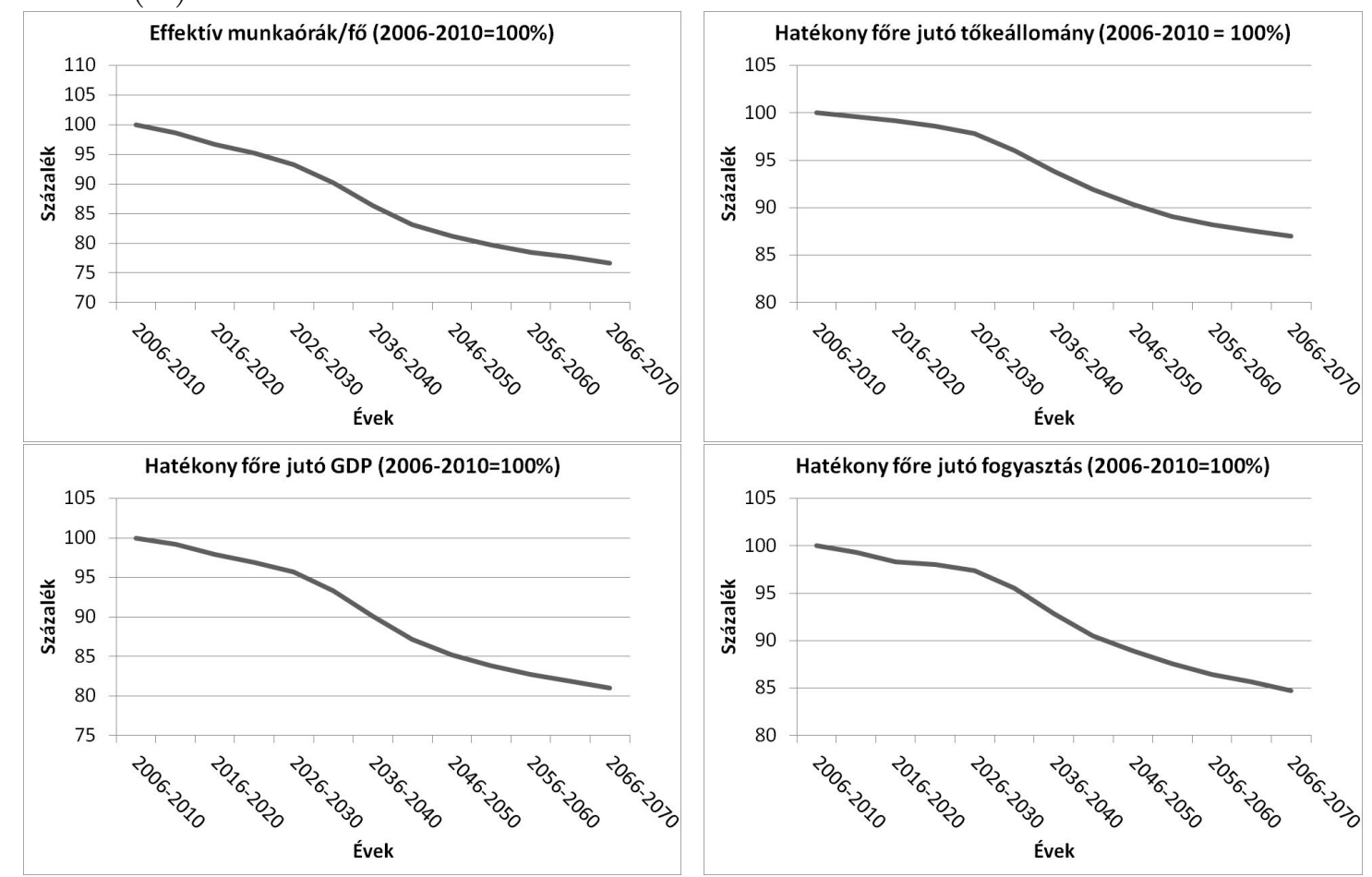

Az alacsonyabb fajlagos jövedelmeknek köszönhetően, a kisebb fajlagos fogyasztás ellenére a háztartások hatékony főre jutó vagyonfelhalmozása is csökken, de csak 6,14 \%-kal 4.8. ábra). Változatlan vagyonfelhalmozási viselkelkedés mellett a hatékony före jutó vagyon ennél sokkal jobban, 25,1 \%-kal csökkent volna pusztán a népesség öregedése miatt (az életciklus motívumok miatt már alacsony vagyonnal rendelkezô idősebb korosztályok súlya megnő), de az öngondoskodás javulásának köszönhetóen 40 és 85 éves korra már magasabb vagyont halmoznak fel a háztartások, ami enyhíti az aggregált hatást (4.2. táblázat). Éppen ez a többletmegtakarítás az, amely lehetővé teszi, hogy GDP-arányosan a háztartások vagyona már ne csökkenjen, hanem nôjön. A külsô adósság GDP-arányosan ezzel csökken, megengedve a kockázati prémium és a kamatok mérséklődését. A kamatlábhoz igazodó bérleti díjak csökkenése valamennyit ellensúlyoz a tôke határtermékének kezdeti csökkenéséból, így a vállalatok fajlagos tőkekereslete kevésbé mérséklődik. A tôke- 
intenzívebb termelés (a magasabb tôke-munka arány) pedig növeli a hatékonysági egységre jutó bruttó reálbéreket.

4.8. ábra. A demográfiai átmenet hatása a makrováltozókra 2006-10 és 2066-70 között (2.)
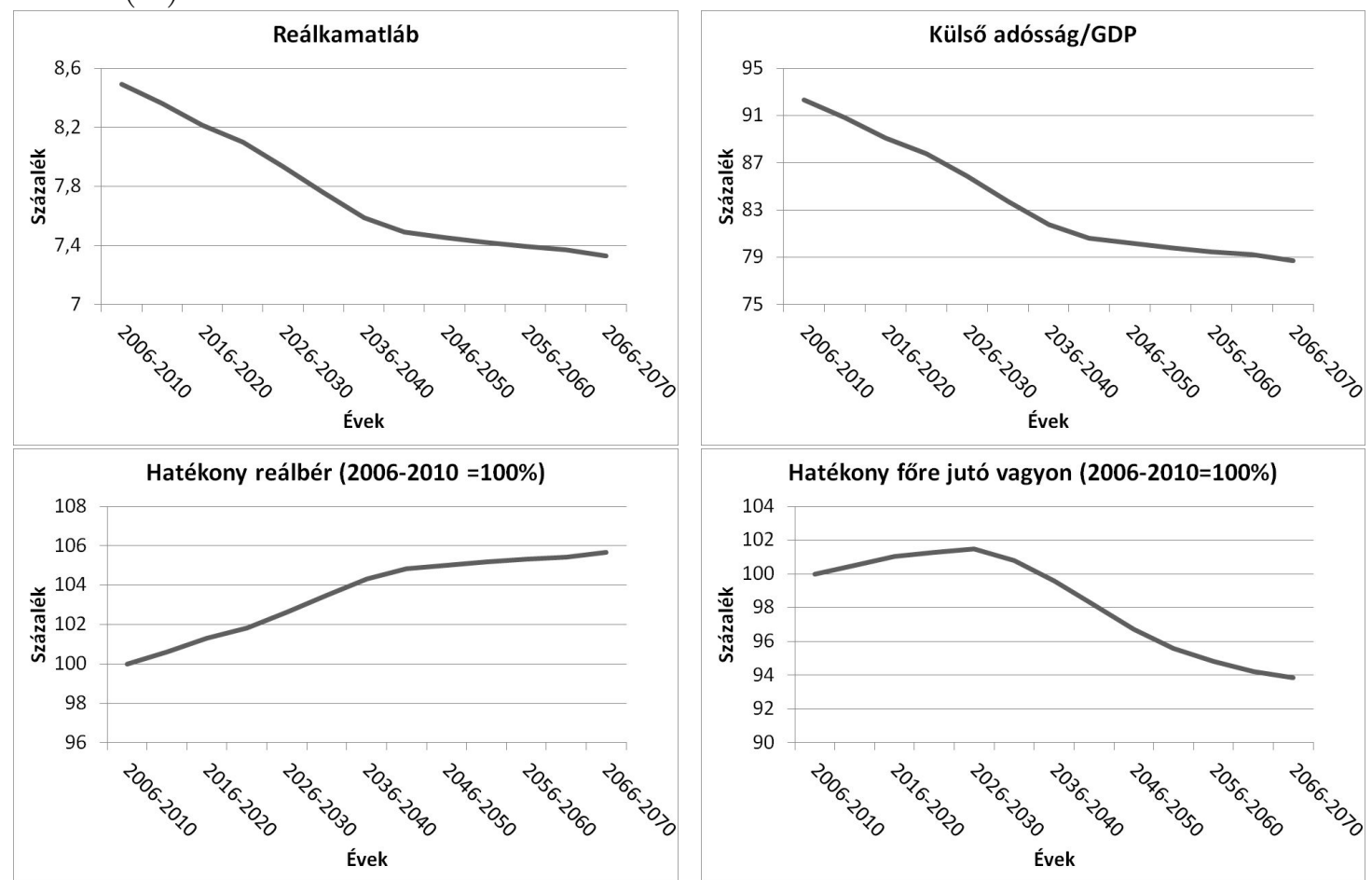

A demográfiai folyamatoknak, a háztartások megváltozott viselkedésének és azok makrogazdasági hatásainak köszönhetôen a nyugdíjrendszer kiadásai a GDP 11,32 \%-áról a 23,3 \%-ára nőnek változatlan nyugdíkorhatár mellett (4.9. ábra). A nyugdíjrendszer hiánya a GDP 0,67 \%-áról a 12,37\%-ára emelkedik, jelentôsen terhelve ezzel az állami költségvetést, amely a magasabb kiadások ellentételezésére a fogyasztási adók kulcsát 28,35 \%-ról 43,07 \%-ra emeli19. A változások nem egyen-

${ }^{19}$ A rendkívül magas fogyasztási adókulcs politikai megvalósíthatóságának kérdését ebben a tanulmányban nem vizsgáljuk. Meg kell jegyezni azonban, hogy Magyarországon az adóelkerülés mértéke - mind a fogyasztási, mind a munkajövedelem adók és járulékok tekintetében már jelenleg is magas, ezért az effektív fogyasztási adókulcs növelése feltehetóen nagy nehézségekbe ütközne. Az állami költségvetés kiegyensúlyozásának alternatív eszköze lehetett volna 
4. fejezet: Demográfiai átmenet és parametrikus nyugdíjreformok hatása a gazdasági növekedésre és a nyugdíjrendszer fenntarthatóságára

letesek: meredekebben emelkednek a mutatók a Ratkó-unokák nyugdíjba vonulását követően.

A fogyasztók várhatóan több idôt töltenek nyugdíjban, így változatlan nyugdíjparaméterek mellett a 2006-10-ben született korosztály 60 éves korban várható nyugdíjának jelenértéke a reálbérhez viszonyítva mintegy 30,9\%-kal meghaladja a az 1951-55-ös korosztályét 4.10, ábra).

4.9. ábra. A demográfiai átmenet hatása az állami költségvetésre 2006-10 és 2066-70 között
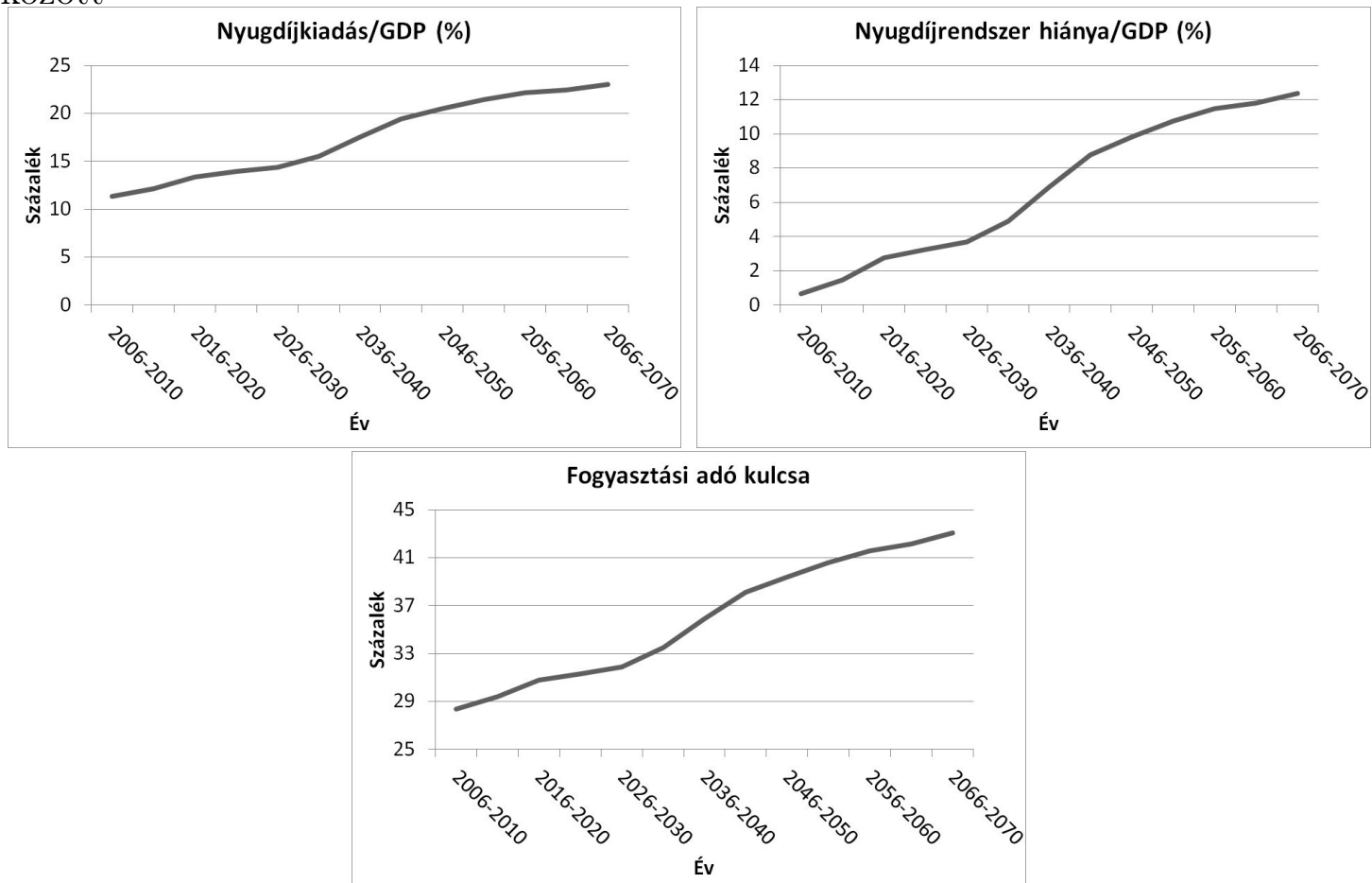

a járulékkulcsok emelése, illetve a helyettesítési ráta drasztikus csökkentése, azonban a polikai fenntarthatatlanság kérdése ezekben az esetekben is felmerült volna. 
4.10. ábra. Az 1951-55 és 2006-10 között született kohorszok 60 éves korban várható nyugdíjának jelenértéke a reálbérhez viszonyítva: 1951-55-ös kohorsz=100\%

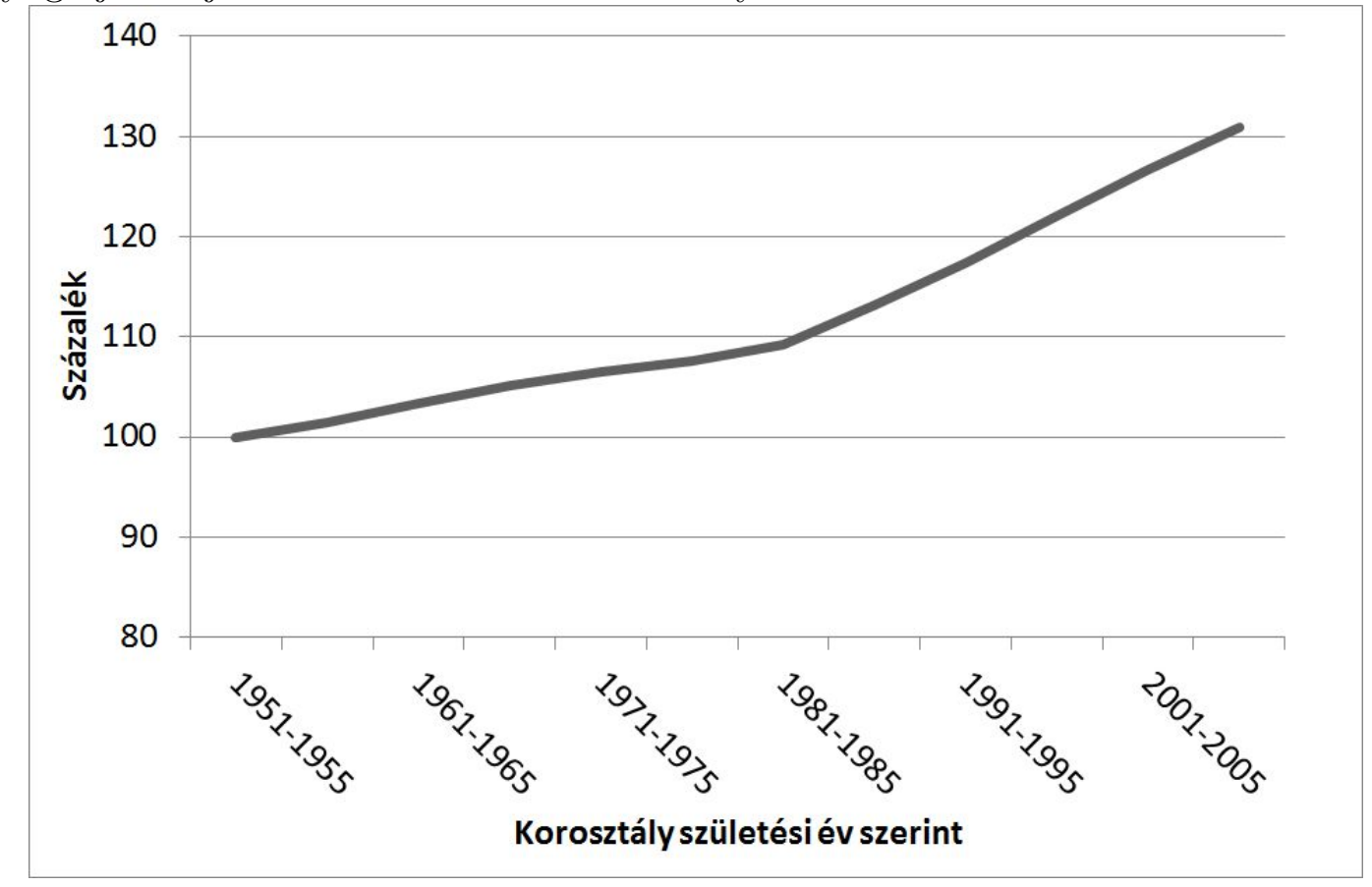

\section{Parametrikus nyugdíjreformok hatása}

A továbbiakban parametrikus nyugdíjreformoknak a hatását vizsgáljuk a makrogazdaságra, a társadalombiztosítási nyugdíjrendszer kiadásaira és a nyugdíjkassza egyenlegére. Az ún. "egyszerü" reformok a következők: a helyettesítési ráta 10 százalékpontos csökkentése (hely.ráta), a járulékkulcs 5 százalékpontos emelése (járulék), a nyugdíjkorhatár megemelése 5 évvel (korhatár) és a nyugdíjak értékét rögzítő svájci indexálás árindexálásra cserélése (index). Valamennyi reformot 2011-15-ben vezetik be, váratlanul.

Ahogy látható lesz, a fenti reformok egyenként nem képesek a vizsgált idôhorizonton stabilizálni a nyugdíjrendszer GDP-arányos hiányát, ezért az elôzô reformoknak néhány kombinációját ("összetett reformok") is megvizsgálom, ahol az elsô esetben a helyettesítési ráta csökkentését, a nyugdíjkorhatár emelését és az inde- 
4. fejezet: Demográfiai átmenet és parametrikus nyugdíjreformok hatása a gazdasági növekedésre és a nyugdíjrendszer fenntarthatóságára

xálás cseréjét egyszerre valósítják meg (összetett1), a második esetben ezeken felül a járulékkulcsot is megemelik (összetett2).

A fontosabb makromutatókat szemügyre véve látható, hogy a járulékemeléstôl eltekintve az "egyszerü" reformok - leginkább a korhatáremelés - mérsékelni tudták a hatékony fôre jutó GDP, az effektív munka, a hatékony fôre jutó tôke, fogyasztás és vagyon visszaesését. A két reformtól azonban eltér a korhatáremelés abban, hogy - a járulékemeléshez hasonlóan - a GDP-arányos külsô adósságot és a reálkamatot növeli, a fajlagos reábért pedig csökkenti 4.34.10. táblázat).

Ahogy az alappálya makrováltozóinak értelmezésénél láttuk, a gazdaság külsô egyensúlyát elsôsorban a háztartások GDP-arányos vagyonfelhalmozási viselkedése határozza meg. A járulékemelés és a korhatáremelés reformjai azok, amelyek az alappályához képest visszafogják ezt a mutatót. A járulékemelés (járulék) fékezi a háztartások munkakínálatát és jövedelmeit, kezdetben (2030-ig) a fogyasztás csökkenésénél erôteljesebben, hiszen a munkát terhelô adók súlya megemelkedik a fogyasztást terhelő adóké pedig csökken, ezért vagyonuk az alappályához képest (GDP-arányosan is) csökken. Késôbb bekövetkezik némi visszarendezôdés, de összességében 2070-ig a reform csökkenti a jövedelemarányos vagyonfelhalmozást, növeli a GDP-arányos külsô adósságot és a kamatokat is. A kamatokkal párhuzamosan emelkedő tôke bérleti díjak csökkentik a termelés tôkeintenzitását, a fajlagos reálbérek pedig ezzel csökkennek.

A korhatáremelés makrogazdasági hatásai mások, de a GDP-arányos külsô adósságot végül hasonlóan befolyásolják. Az idôsebb, 61-65 éves korosztály bevonásával az effektív munkakínálat jelentősen nő az alappályához viszonyítva, a fogyasztás viszont nem nô ugyanilyen mértékben (jövedelmet a reform elótt is kaptak nyugdíjból a 61-65 évesek, ezért az életpályájuk során felhasználható jövedelmeik és ezzel fogyasztásuk nem nőtt annyira, mint a munkakínálatuk). A vagyonfelhalmozás így az alappályához képest ugyan magasabb, de az output növekedésénél kisebb. A GDP-arányos vagyon csökkenése pedig a járulékemeléshez hasonlóan a kamatok növekedéséhez, és a fajlagos reálbér illetve a tôkeintenzitás csökkenéséhez vezet. 
A helyettesítési ráta csökkentése és az árindexálás bevezetése a korhatáremeléshez hasonlóan, de kisebb mértékben ösztönzik a munkakínálatot. A fogyasztás viszont kevésbé nô, az idôsebb korban kapott alacsonyabb nyugdíj miatt a fiatalabbak többet takarítanak meg, az alappályához képest a vagyonfelhalmozás ezúttal GDP-arányosan is emelkedik. A mérséklődő kockázati prémium miatt a tóke bérleti díja is csökken, ami beruházásokhoz, a tôkeintenzitás és a fajlagos reálbérek növekedéséhez járul hozzá.

Az "összetett" reformok hatásmechanizmusa "kikeverhetô" az egyszerû reformokéból, ezért esetükben inkább az az érdekes, hogy milyen nagyságrendben tudják befolyásolni a gazdaság makropályáját az alappályához képest. A helyettesítésirátacsökkentés, az árindexálás és a korhatáremelés (összetett1) együttes végrehajtása esetén az effektív munkaórák száma 6,59 \%-kal is nagyobb lehet 2066-70-re. Ezzel párhuzamosan 2066-70-re a GDP 7,73, a fogyasztás 7,15, a vagyon 11,95, a tôkeállomány 10,47 \%-kal nő, a GDP-arányos külső adósság 2,55 százalékponttal mérséklődik, a reálbérek viszont csak 1,07 \%-kal nônek. A kedvező makrogazdasági hatásokat mérsékli, ha az elóbb említett reformok mellett a járulékkulcsot is megemelik (összetett2). 
4. fejezet: Demográfiai átmenet és parametrikus nyugdíjreformok hatása a gazdasági növekedésre és a nyugdíjrendszer fenntarthatóságára

4.3. táblázat. A hatékony fớre jutó munkakínálat \%-os eltérése az alappályájától 2006-10 és 2066-70 között, parametrikus nyugdíjreformok mellett

\begin{tabular}{|l|c|c|c|c|c|c|}
\hline Idôszak & hely.ráta & járulék & korhatár & index & összetett1 & összetett2 \\
\hline \hline 2011-2015 & 0,38 & $-1,60$ & 3,92 & $-0,62$ & 3,55 & 1,71 \\
$2016-2020$ & 0,45 & $-1,72$ & 4,74 & $-0,21$ & 4,87 & 2,84 \\
$2021-2025$ & 0,44 & $-1,53$ & 3,88 & 0,10 & 4,29 & 2,49 \\
$2026-2030$ & 0,57 & $-1,51$ & 3,64 & 0,39 & 4,41 & 2,66 \\
$2031-2035$ & 0,74 & $-1,47$ & 4,33 & 0,54 & 5,38 & 3,64 \\
$2036-2040$ & 0,89 & $-1,42$ & 5,35 & 0,56 & 6,58 & 4,86 \\
$2041-2045$ & 0,94 & $-1,36$ & 5,62 & 0,53 & 6,90 & 5,26 \\
$2046-2050$ & 0,91 & $-1,30$ & 5,23 & 0,52 & 6,49 & 4,92 \\
$2051-2055$ & 0,88 & $-1,26$ & 5,30 & 0,54 & 6,55 & 5,02 \\
$2056-2060$ & 0,85 & $-1,23$ & 5,19 & 0,61 & 6,48 & 4,99 \\
$2061-2065$ & 0,85 & $-1,23$ & 4,89 & 0,71 & 6,26 & 4,78 \\
$2066-2070$ & 0,88 & $-1,23$ & 5,13 & 0,77 & 6,59 & 5,11 \\
\hline \hline
\end{tabular}

4.4. táblázat. A hatékony fơre jutó fogyasztás \%-os eltérése az alappályájától 2006-10 és 2066-70 között, parametrikus nyugdíjreformok mellett

\begin{tabular}{|l|c|c|c|c|c|c|}
\hline Időszak & hely.ráta & járulék & korhatár & index & összetett1 & összetett2 \\
\hline \hline $2011-2015$ & $-0,69$ & $-0,27$ & 3,03 & $-1,98$ & 0,61 & 0,21 \\
$2016-2020$ & 0,07 & $-1,01$ & 3,23 & $-0,46$ & 2,85 & 1,72 \\
$2021-2025$ & 0,53 & $-1,50$ & 2,43 & 0,48 & 3,33 & 1,68 \\
$2026-2030$ & 0,83 & $-1,75$ & 2,38 & 1,00 & 3,99 & 2,07 \\
$2031-2035$ & 1,17 & $-1,86$ & 3,23 & 1,18 & 5,24 & 3,14 \\
$2036-2040$ & 1,56 & $-1,83$ & 4,21 & 1,17 & 6,49 & 4,32 \\
$2041-2045$ & 1,82 & $-1,74$ & 4,36 & 1,16 & 6,82 & 4,73 \\
$2046-2050$ & 1,85 & $-1,66$ & 4,01 & 1,23 & 6,59 & 4,63 \\
$2051-2055$ & 1,83 & $-1,58$ & 4,23 & 1,33 & 6,85 & 4,97 \\
$2056-2060$ & 1,78 & $-1,52$ & 4,17 & 1,46 & 6,87 & 5,05 \\
$2061-2065$ & 1,71 & $-1,51$ & 3,93 & 1,61 & 6,73 & 4,95 \\
$2066-2070$ & 1,72 & $-1,50$ & 4,26 & 1,70 & 7,15 & 5,35 \\
\hline \hline
\end{tabular}


4.5. táblázat. A hatékony fôre jutó vagyon \%-os eltérése az alappályájától 2006-10 és 2066-70 között, parametrikus nyugdíjreformok mellett

\begin{tabular}{|l|c|c|c|c|c|c|}
\hline Időszak & hely.ráta & járulék & korhatár & index & összetett1 & összetett2 \\
\hline \hline $2011-2015$ & 1,49 & $-1,42$ & $-0,02$ & 2,39 & 3,36 & 1,87 \\
$2016-2020$ & 2,44 & $-2,23$ & $-0,09$ & 3,69 & 5,26 & 2,81 \\
$2021-2025$ & 3,14 & $-2,53$ & 0,24 & 4,36 & 6,69 & 3,82 \\
$2026-2030$ & 3,83 & $-2,58$ & 0,78 & 4,71 & 7,98 & 4,94 \\
$2031-2035$ & 4,42 & $-2,46$ & 1,17 & 4,975 & 8,97 & 5,96 \\
$2036-2040$ & 4,74 & $-2,29$ & 1,24 & 5,26 & 9,55 & 6,69 \\
$2041-2045$ & 4,79 & $-2,14$ & 1,29 & 5,58 & 9,95 & 7,25 \\
$2046-2050$ & 4,75 & $-2,00$ & 1,55 & 5,90 & 10,47 & 7,87 \\
$2051-2055$ & 4,69 & $-1,90$ & 1,65 & 6,20 & 10,82 & 8,31 \\
$2056-2060$ & 4,68 & $-1,84$ & 1,69 & 6,48 & 11,13 & 8,66 \\
$2061-2065$ & 4,77 & $-1,80$ & 1,88 & 6,70 & 11,60 & 9,13 \\
$2066-2070$ & 4,90 & $-1,76$ & 1,97 & 6,88 & 11,95 & 9,50 \\
\hline \hline
\end{tabular}

4.6. táblázat. A hatékony före jutó tókeállomány \%-os eltérése az alappályájától 2006-10 és 2066-70 között, parametrikus nyugdíjreformok mellett

\begin{tabular}{|l|c|c|c|c|c|c|}
\hline Időszak & hely.ráta & járulék & korhatár & index & összetett1 & összetett2 \\
\hline \hline $2011-2015$ & 1,47 & $-1,99$ & 1,84 & 1,79 & 4,61 & 2,43 \\
$2016-2020$ & 1,85 & $-2,07$ & 1,49 & 2,55 & 5,30 & 2,95 \\
$2021-2025$ & 2,36 & $-2,23$ & 1,47 & 3,06 & 6,07 & 3,51 \\
$2026-2030$ & 2,89 & $-2,22$ & 1,82 & 3,37 & 7,04 & 4,42 \\
$2031-2035$ & 3,36 & $-2,12$ & 2,31 & 3,61 & 8,08 & 5,48 \\
$2036-2040$ & 3,60 & $-1,99$ & 2,60 & 3,86 & 8,80 & 6,33 \\
$2041-2045$ & 3,62 & $-1,87$ & 2,62 & 4,11 & 9,10 & 6,75 \\
$2046-2050$ & 3,58 & $-1,76$ & 2,68 & 4,33 & 9,32 & 7,05 \\
$2051-2055$ & 3,54 & $-1,69$ & 2,77 & 4,56 & 9,61 & 7,41 \\
$2056-2060$ & 3,54 & $-1,65$ & 2,73 & 4,79 & 9,79 & 7,62 \\
$2061-2065$ & 3,64 & $-1,62$ & 2,80 & 4,98 & 10,09 & 7,91 \\
$2066-2070$ & 3,75 & $-1,59$ & 2,94 & 5,13 & 10,47 & 8,30 \\
\hline
\end{tabular}


4. fejezet: Demográfiai átmenet és parametrikus nyugdíjreformok hatása a gazdasági növekedésre és a nyugdíjrendszer fenntarthatóságára

4.7. táblázat. A hatékony fôre jutó kibocsátás \%-os eltérése az alappályájától 2006-10 és 2066-70 között, parametrikus nyugdíjreformok mellett

\begin{tabular}{|l|c|c|c|c|c|c|}
\hline Időszak & hely.ráta & járulék & korhatár & index & összetett1 & összetett2 \\
\hline \hline $2011-2015$ & 0,25 & $-1,08$ & 2,61 & $-0,42$ & 2,37 & 1,14 \\
$2016-2020$ & 0,79 & $-1,81$ & 3,78 & 0,44 & 4,78 & 2,70 \\
$2021-2025$ & 0,90 & $-1,71$ & 3,08 & 0,90 & 4,62 & 2,65 \\
$2026-2030$ & 1,16 & $-1,75$ & 2,92 & 1,26 & 4,95 & 2,94 \\
$2031-2035$ & 1,45 & $-1,72$ & 3,49 & 1,46 & 5,93 & 3,90 \\
$2036-2040$ & 1,70 & $-1,65$ & 4,34 & 1,56 & 7,07 & 5,07 \\
$2041-2045$ & 1,81 & $-1,57$ & 4,61 & 1,62 & 7,53 & 5,61 \\
$2046-2050$ & 1,80 & $-1,49$ & 4,36 & 1,69 & 7,34 & 5,52 \\
$2051-2055$ & 1,76 & $-1,42$ & 4,43 & 1,77 & 7,46 & 5,69 \\
$2056-2060$ & 1,73 & $-1,38$ & 4,39 & 1,90 & 7,50 & 5,78 \\
$2061-2065$ & 1,73 & $-1,37$ & 4,17 & 2,04 & 7,41 & 5,71 \\
$2066-2070$ & 1,78 & $-1,36$ & 4,35 & 2,14 & 7,73 & 6,02 \\
\hline \hline
\end{tabular}

4.8. táblázat. A GDP-arányos külsô adósság százalékpontos eltérése az alappályájától 2006-10 és 2066-70 között, parametrikus nyugdíjreformok mellett

\begin{tabular}{|l|c|c|c|c|c|c|}
\hline Idôszak & hely.ráta & járulék & korhatár & index & összetett1 & összetett2 \\
\hline \hline 2011-2015 & 0,32 & $-1,34$ & 3,22 & $-0,52$ & 2,92 & 1,41 \\
$2016-2020$ & $-0,83$ & 0,23 & 2,33 & $-1,64$ & 0,21 & 0,33 \\
$2021-2025$ & $-1,15$ & 0,46 & 1,92 & $-1,97$ & $-0,79$ & $-0,37$ \\
$2026-2030$ & $-1,43$ & 0,60 & 1,74 & $-2,13$ & $-1,29$ & $-0,68$ \\
$2031-2035$ & $-1,70$ & 0,62 & 1,98 & $-2,24$ & $-1,26$ & $-0,60$ \\
$2036-2040$ & $-1,94$ & 0,57 & 2,36 & $-2,39$ & $-1,12$ & $-0,47$ \\
$2041-2045$ & $-2,07$ & 0,51 & 2,33 & $-2,59$ & $-1,40$ & $-0,81$ \\
$2046-2050$ & $-2,10$ & 0,46 & 2,01 & $-2,79$ & $-1,92$ & $-1,38$ \\
$2051-2055$ & $-2,10$ & 0,41 & 2,02 & $-2,93$ & $-2,04$ & $-1,52$ \\
$2056-2060$ & $-2,09$ & 0,37 & 1,86 & $-3,05$ & $-2,30$ & $-1,81$ \\
$2061-2065$ & $-2,08$ & 0,34 & 1,66 & $-3,14$ & $-2,59$ & $-2,11$ \\
$2066-2070$ & $-2,12$ & 0,32 & 1,79 & $-3,22$ & $-2,55$ & $-2,08$ \\
\hline
\end{tabular}


4.9. táblázat. A reálkamatláb százalékpontos eltérése az alappályájától 2006-10 és 2066-70 között, parametrikus nyugdíjreformok mellett

\begin{tabular}{|l|c|c|c|c|c|c|}
\hline Időszak & hely.ráta & járulék & korhatár & index & összetett1 & összetett2 \\
\hline \hline $2011-2015$ & 0,03 & $-0,12$ & 0,28 & $-0,04$ & 0,25 & 0,12 \\
$2016-2020$ & $-0,07$ & 0,02 & 0,20 & $-0,14$ & 0,02 & 0,03 \\
$2021-2025$ & $-0,10$ & 0,04 & 0,16 & $-0,17$ & $-0,07$ & $-0,03$ \\
$2026-2030$ & $-0,12$ & 0,05 & 0,15 & $-0,18$ & $-0,11$ & $-0,06$ \\
$2031-2035$ & $-0,15$ & 0,05 & 0,17 & $-0,19$ & $-0,11$ & $-0,05$ \\
$2036-2040$ & $-0,16$ & 0,05 & 0,20 & $-0,20$ & $-0,10$ & $-0,04$ \\
$2041-2045$ & $-0,18$ & 0,04 & 0,20 & $-0,22$ & $-0,12$ & $-0,07$ \\
$2046-2050$ & $-0,18$ & 0,04 & 0,17 & $-0,24$ & $-0,16$ & $-0,12$ \\
$2051-2055$ & $-0,18$ & 0,03 & 0,17 & $-0,25$ & $-0,17$ & $-0,13$ \\
$2056-2060$ & $-0,18$ & 0,03 & 0,16 & $-0,26$ & $-0,20$ & $-0,15$ \\
$2061-2065$ & $-0,18$ & 0,03 & 0,14 & $-0,27$ & $-0,22$ & $-0,18$ \\
$2066-2070$ & $-0,18$ & 0,03 & 0,15 & $-0,27$ & $-0,22$ & $-0,18$ \\
\hline \hline
\end{tabular}

4.10. táblázat. A hatékonysági egységre jutó reálbér \%-os eltérése az alappályájától 2006-10 és 2066-70 között, parametrikus nyugdíjreformok mellett

\begin{tabular}{|l|c|c|c|c|c|c|}
\hline Időszak & hely.ráta & járulék & korhatár & index & összetett1 & összetett2 \\
\hline \hline $2011-2015$ & $-0,13$ & 0,53 & $-1,26$ & 0,21 & $-1,15$ & $-0,56$ \\
$2016-2020$ & 0,33 & $-0,09$ & $-0,92$ & 0,66 & $-0,08$ & $-0,13$ \\
$2021-2025$ & 0,46 & $-0,18$ & $-0,76$ & 0,80 & 0,32 & 0,15 \\
$2026-2030$ & 0,58 & $-0,24$ & $-0,70$ & 0,87 & 0,52 & 0,27 \\
$2031-2035$ & 0,70 & $-0,25$ & $-0,80$ & 0,92 & 0,52 & 0,25 \\
$2036-2040$ & 0,80 & $-0,23$ & $-0,96$ & 0,99 & 0,46 & 0,20 \\
$2041-2045$ & 0,86 & $-0,21$ & $-0,95$ & 1,08 & 0,58 & 0,33 \\
$2046-2050$ & 0,88 & $-0,19$ & $-0,82$ & 1,17 & 0,80 & 0,57 \\
$2051-2055$ & 0,88 & $-0,17$ & $-0,83$ & 1,23 & 0,85 & 0,63 \\
$2056-2060$ & 0,87 & $-0,15$ & $-0,76$ & 1,28 & 0,96 & 0,76 \\
$2061-2065$ & 0,87 & $-0,14$ & $-0,69$ & 1,32 & 1,09 & 0,89 \\
$2066-2070$ & 0,89 & $-0,13$ & $-0,74$ & 1,36 & 1,07 & 0,87 \\
\hline \hline
\end{tabular}


4. fejezet: Demográfiai átmenet és parametrikus nyugdíjreformok hatása a gazdasági növekedésre és a nyugdíjrendszer fenntarthatóságára

Az "egyszerû" reformok közül (hely.ráta-index) a GDP-arányos nyugdíjkiadásokat emelkedését mind hosszabb távon, 2066-70-ig, mind a reform megvalósítását követő években a korhatáremelés (korhatár) fékezi a leginkább, de végül így is jelentősen megugranak a GDP 19,58 \%-ára. A legkisebb mértékben, a GDP-nek mintegy 1,89\%-ával pedig a járulékkulcs megemelése (járulék) csökkenti a kiadásokat az alappályához képest. Igaz, ez a reform a nyugdíjrendszer hiányát elsôsorban a bevételek növelésével igyekszik visszafogni, de a nettó bérek közvetlen mérséklésével és a munkakínálat elbátortalanításával az egyes korosztályok induló nyugdíját is csökkenti 4.11. táblázat).

A nyugdíjrendszer GDP-arányos hiányának emelkedését hosszú távon a járulékemelés fékezte a leginkább: az alapváltozat 12,37 \%-ához képest a hiány csak a GDP 7,2 \%-át éri így el 2066-70-re. A többi reform hosszú távú hatása nagyon hasonló az egyenlegre, valamennyi esetben a GDP körülbelül 9-9,5 \%-ára emelkedik a hiány. Időbeli lefutásukat tekintve azonban a korhatáremelés rövid távú egyenlegjavító hatásai erôsebbek, a járulékemeléshez hasonlóan a reformot követô 5-10 évben még szufficitessé is tudja tenni a nyugdíjrendszer egyenlegét (4.12. táblázat).

A helyettesítésiráta-csökkentés, a korhatáremelés és az árindexálás együttes bevezetése (összetett1) a reformot követôen mintegy 3,64 százalékponttal javítja a GDP-arányos egyenleget, 2041-45-re "helyreáll" a kiinduló állapot közel kiegyensúlyozott egyenlege, majd 2070-re a hiány a GDP 4,5\%-ára nô. A járulékkulcs megemelésével együtt (összetett2) azonban már elegendőnek bizonyulnak ahhoz, hogy a GDP-arányos hiányt egészen 2070-ig eltüntessék. A két reform azonnali hatásaként a GDP-arányos nyugdíjkiadások 7,5-7-7\%-ra csökkennek, de aztán 2041-50-ig elérik a kiinduló szintjüket, és végül a GDP 14-15\%-ára nőnek. A költségvetésre rótt alacsonyabb teher lehetôvé teszi, hogy a fogyasztási adó kulcsát kevésbé emeljék. Az egyszerú reformok 2026-35-ig csökkentik a fogyasztási adó kulcsát, de 2070-ig is 4 (korhatár), illetve 8 (járulék) százalékponttal kisebb emelést tesznek szükségessé, mint az alapesetben. Az "összetett" reformok közül az első (összetett1) 2046-50-ig csökkenti a GDP-arányos államadósság szinten tartásához szükséges adókulcsot, a bôvebb reform (összetett2) pedig alacsonyabb, 23,82 \%-os kulcsot engednek meg még 2070-ben is (4.13. táblázat). 
Eközben a 60 éves korban várható nyugdíjak jelenértéke is csökken az adott időszak béreihez képest (4.14. táblázat). Az egyszerú reformok közül a legjobban a korhatáremelés (korhatár), a legkevésbé az árindexálás (index) bevezetésének hatására. A járulékkulcs emelése (járulék) nem azonnal fejti ki hatását: a közvetlenül a reformokat követôen nyugdíjba vonuló korosztályok várható nyugdíjai még nem csökkennek olyan mértékben, mint a fiatalabb kohorszoké. A korhatáremelés (korhatár) és a helyettesítésiráta-csökkentés (hely.ráta) esetében megfigyelhetô, hogy a fiatalabb kohorsz nyugdíjvagyona már kevésbé csökken, az aktív életkorban ledolgozott több munkaórának köszönhetően. A várható nyugdíjak jelenértéke a reálbérhez képest az "összetett" reformok hatására már számottevô mértékben, több, mint harmadával is csökkenhet, az idôsek jelentős relatív elszegényedésését okozva.

4.11. táblázat. A GDP-arányos nyugdíjkiadások alakulása a parametrikus nyugdíjreformok mellett

\begin{tabular}{|l|c|c|c|c|c|c|c|}
\hline Időszak & alap & hely.ráta & járulék & korhatár & index & összetett1 & összetett2 \\
\hline \hline $2011-2015$ & 12,13 & 11,62 & 12,25 & 8,17 & 11,75 & 7,68 & 7,87 \\
$2016-2020$ & 13,39 & 12,35 & 13,49 & 9,32 & 12,53 & 8,09 & 8,25 \\
$2021-2025$ & 13,92 & 12,56 & 13,83 & 10,95 & 12,72 & 9,17 & 9,17 \\
$2026-2030$ & 14,36 & 12,73 & 14,09 & 11,80 & 12,92 & 9,61 & 9,47 \\
$2031-2035$ & 15,55 & 13,61 & 15,04 & 12,42 & 14,02 & 9,95 & 9,67 \\
$2036-2040$ & 17,57 & 15,25 & 16,73 & 13,55 & 15,99 & 10,82 & 10,36 \\
$2041-2045$ & 19,43 & 16,82 & 18,26 & 15,31 & 17,77 & 12,28 & 11,59 \\
$2046-2050$ & 20,48 & 17,74 & 19,07 & 16,87 & 18,64 & 13,55 & 12,64 \\
$2051-2055$ & 21,41 & 18,57 & 19,81 & 17,76 & 19,33 & 14,17 & 13,12 \\
$2056-2060$ & 22,13 & 19,22 & 20,39 & 18,62 & 19,77 & 14,74 & 13,59 \\
$2061-2065$ & 22,47 & 19,51 & 20,66 & 19,30 & 19,82 & 15,13 & 13,91 \\
$2066-2070$ & 23,03 & 19,98 & 21,14 & 19,58 & 20,16 & 15,18 & 13,94 \\
\hline \hline
\end{tabular}


4. fejezet: Demográfiai átmenet és parametrikus nyugdíjreformok hatása a gazdasági növekedésre és a nyugdíjrendszer fenntarthatóságára

4.12. táblázat. A nyugdíjrendszer GDP-arányos hiánya 2006-10 és 2066-70 között parametrikus nyugdíjreformok mellett

\begin{tabular}{|l|c|c|c|c|c|c|c|}
\hline Idôszak & alap & hely.ráta & járulék & korhatár & index & összetett1 & összetett2 \\
\hline \hline $2011-2015$ & 1,48 & 0,96 & $-1,76$ & $-2,48$ & 1,10 & $-2,97$ & $-6,14$ \\
$2016-2020$ & 2,74 & 1,69 & $-0,51$ & $-1,33$ & 1,88 & $-2,56$ & $-5,75$ \\
$2021-2025$ & 3,26 & 1,91 & $-0,18$ & 0,30 & 2,06 & $-1,48$ & $-4,83$ \\
$2026-2030$ & 3,70 & 2,08 & 0,09 & 1,14 & 2,27 & $-1,05$ & $-4,53$ \\
$2031-2035$ & 4,90 & 2,96 & 1,04 & 1,77 & 3,36 & $-0,71$ & $-4,34$ \\
$2036-2040$ & 6,91 & 4,59 & 2,73 & 2,90 & 5,34 & 0,17 & $-3,64$ \\
$2041-2045$ & 8,77 & 6,16 & 4,26 & 4,66 & 7,12 & 1,63 & $-2,41$ \\
$2046-2050$ & 9,82 & 7,08 & 5,07 & 6,22 & 7,99 & 2,90 & $-1,36$ \\
$2051-2055$ & 10,76 & 7,92 & 5,80 & 7,10 & 8,68 & 3,52 & $-0,88$ \\
$2056-2060$ & 11,48 & 8,56 & 6,39 & 7,97 & 9,12 & 4,09 & $-0,42$ \\
$2061-2065$ & 11,82 & 8,86 & 6,66 & 8,65 & 9,17 & 4,47 & $-0,10$ \\
$2066-2070$ & 12,37 & 9,33 & 7,13 & 8,93 & 9,51 & 4,53 & $-0,06$ \\
\hline \hline
\end{tabular}

4.13. táblázat. A fogyasztási adó kulcsa 2006-10 és 2066-70 között parametrikus nyugdíjreformok mellett

\begin{tabular}{|l|c|c|c|c|c|c|c|}
\hline Időszak & alap & hely.ráta & járulék & korhatár & index & összetett1 & összetett2 \\
\hline \hline $2011-2015$ & 29,41 & 28,65 & 23,87 & 24,46 & 29,03 & 23,85 & 18,44 \\
$2016-2020$ & 30,78 & 28,93 & 25,30 & 26,40 & 29,16 & 24,00 & 18,63 \\
$2021-2025$ & 31,32 & 28,73 & 25,80 & 28,44 & 28,88 & 24,75 & 19,35 \\
$2026-2030$ & 31,90 & 28,76 & 26,17 & 29,41 & 28,98 & 24,88 & 19,37 \\
$2031-2035$ & 33,49 & 29,75 & 27,42 & 30,20 & 30,41 & 25,17 & 19,50 \\
$2036-2040$ & 35,95 & 31,54 & 29,36 & 31,71 & 32,86 & 26,26 & 20,33 \\
$2041-2045$ & 38,09 & 33,18 & 30,97 & 33,90 & 34,90 & 27,96 & 21,66 \\
$2046-2050$ & 39,38 & 34,28 & 31,88 & 35,75 & 35,88 & 29,32 & 22,65 \\
$2051-2055$ & 40,60 & 35,34 & 32,77 & 36,82 & 36,66 & 29,96 & 23,06 \\
$2056-2060$ & 41,55 & 36,18 & 33,49 & 37,94 & 37,11 & 30,57 & 23,48 \\
$2061-2065$ & 42,16 & 36,73 & 33,97 & 38,84 & 37,22 & 30,97 & 23,76 \\
$2066-2070$ & 43,07 & 37,50 & 34,76 & 39,30 & 37,78 & 31,06 & 23,82 \\
\hline
\end{tabular}


4.14. táblázat. Az 1951-55 és 2006-10 között született kohorszok 60 éves korban várható nyugdíjának jelenértéke a reálbérhez viszonyítva: \%-os eltérés az alappályától

\begin{tabular}{|l|c|c|c|c|c|c|}
\hline Korosztály & hely.ráta & járulék & korhatár & index & összetett1 & összetett2 \\
\hline \hline $1951-1955$ & $-12,44$ & $-2,31$ & $-29,38$ & $-6,46$ & $-38,51$ & $-42,32$ \\
$1956-1960$ & $-11,99$ & $-3,94$ & $-29,78$ & $-5,49$ & $-40,15$ & $-42,86$ \\
$1961-1965$ & $-11,69$ & $-5,34$ & $-29,15$ & $-4,77$ & $-39,15$ & $-42,79$ \\
$1966-1970$ & $-11,44$ & $-6,73$ & $-29,28$ & $-4,11$ & $-39,03$ & $-43,45$ \\
$1971-1975$ & $-11,23$ & $-7,88$ & $-29,22$ & $-3,95$ & $-39,00$ & $-44,08$ \\
$1976-1980$ & $-11,11$ & $-8,79$ & $-28,62$ & $-4,36$ & $-38,74$ & $-44,34$ \\
$1981-1985$ & $-11,13$ & $-9,57$ & $-27,82$ & $-5,03$ & $-38,42$ & $-44,49$ \\
$1986-1990$ & $-11,09$ & $-9,67$ & $-26,74$ & $-5,27$ & $-37,45$ & $-43,65$ \\
$1991-1995$ & $-11,16$ & $-9,64$ & $-26,06$ & $-5,78$ & $-37,12$ & $-43,33$ \\
$1996-2000$ & $-11,19$ & $-9,66$ & $-25,49$ & $-6,07$ & $-36,79$ & $-43,06$ \\
$2001-2005$ & $-11,20$ & $-9,67$ & $-24,93$ & $-6,18$ & $-36,40$ & $-42,72$ \\
$2006-2010$ & $-11,18$ & $-9,66$ & $-24,41$ & $-6,28$ & $-36,01$ & $-42,37$ \\
\hline \hline
\end{tabular}

\subsubsection{Következtetések és továbblépési irányok}

A demográfiai folyamatok alakulása a közeljövőben jelentős terhet ró majd a fejlett államok költségvetésére a nyugdíjrendszer finanszírozási nehézségei miatt, és ezzel párhuzamosan visszafogja a potenciális növekedésüket. A demográfiai átmenetnek a magyar nyugdíjrendszerre és a makrogazdaságra gyakorolt hatását egy együttélő korosztályokat tartalmazó kis nyitott gazdaságban szimuláltuk, ahol a szereplők rugalmasan reagálnak megtakarításaikkal és munkakínálatukkal a változásokra. A 2000-es évek elsô évtizedének magyar gazdaságára kalibrált modellben az átmenet folyamatait hat évtizeden keresztül követtük végig. A vizsgált idôszakban a népesség szerkezeti átrendeződése, a munkaképes korú és jelentôs vagyonnal rendelkezô háztartások arányának csökkenése önmagában számottevôen mérsékli a hatékony munkakínálatot, a hatékony főre jutó tôkekínálatot, és az egy főre jutó GDP-t a technikai haladás által indokolt emelkedéshez képest. Egy dekompozíciós 
4. fejezet: Demográfiai átmenet és parametrikus nyugdíjreformok hatása a gazdasági növekedésre és a nyugdíjrendszer fenntarthatóságára

eljárással azonban megmutatjuk, hogy a kedvezôtlen szerkezeti átalakulások okozta elmaradást mérsékli, hogy a háztartások - reagálva a történtekre - növelik munkakínálatukat és több vagyont halmoznak föl. A többletmegtakarítás a külsô pozíciót is javítja, a mérséklődô kockázati prémium hatására csökkenô kamatok pedig beruházásokat indukálnak, tôkeintenzívebbé teszik a termelést, ez pedig a reálbérekre is kedvezốen hat. Az öregedô társadalomban változatlan nyugdíjparaméterek mellett jelentôsen nônek a GDP-arányos nyugdíjkiadások, a 2006-10-ben született kohorsz 60 éves korban várható nyugdíjának jelenértéke a reálbérhez viszonyítva mintegy 30,9\%-kal meghaladja a az 1951-55-ös korosztályét. A tb-nyugdíjkassza egyenlege 2070-ig a GDP több, mint 10 \%-ával romlik, és a GDP-arányos államadósság stabilizálásához szükséges fogyasztási adókulcs is megemelkedik.

A másik kérdés, amit vizsgáltunk, hogy a nyugdíjrendszer parametrikus változásai hogyan tudják befolyásolni a finanszírozási terhet, melyet a társadalombiztosítási nyugdíjrendszer a költségvetésre ró, illetve miként hatnak vissza a makrováltozók pályájára. Az "egyszerû" parametrikus reformok hosszabb távon megállítani nem, csak lassítani tudják a GDP-arányos kiadásoknak és a tb-hiánynak az emelkedését. A helyettesítési ráta csökkentése, a korhatáremelés és az árindexálás együttes bevezetése az azonnali, a GDP 3,64 \%-ára tehetô egyenlegjavító hatása is csak 2041-45-ig képes megtartani a nyugdíjrendszer egyenlegének kiegyensúlyozottságát. A járulékemeléssel kiegészülve azonban már egészen 2070-ig képes ellensúlyozni a demográfiai átmenet egyenlegrontó hatását, kezdetben pedig több, mint 6 százalékpontos javuláshoz vezet. Ennek ára, hogy az egyes korosztályok 60 éves korban várt nyugdíjainak jelenértéke a reálbérhez képest minden esetben csökken. Az "összetett" reformok esetén a csökkenés minden érintett korosztály számára számottevő, az alappályához képest 36-42\%-os veszteséget jelent, az idôsek jelentôs relatív elszegényedését okozva. A járulékemeléstől eltekintve a reformok ösztönzik a háztartások munka- és tókekínálatát, és együttes végrehajtásuk hatására az effektív munkaórák száma 5,11, a GDP 8,09, a fogyasztás 5,35, a vagyon 9,5, a tókeállomány 8,3 százalékkal is nagyobb lehet 2066-70-re az alappálya értékeinél, a GDP-arányos külső adósság pedig 2,08 százalékponttal mérséklődhet. Járulékemelés nélkül a makrogazdasági hatások még ennél is kedvezőbben alakulhatnak, de a nyugdíjrendszer fenntarthatósága kisebb mértékben javul. 
Az írásban igyekeztünk kiemelni, hogy a demográfiai átmenet, illetve a parametrikus nyugdíjreformok hatásainak értékelésénél fontos figyelembe venni, hogy a háztartások munka- és tôkekínálatukkal reagálnak a változásokra. A reakciók megjelenítése a modellben a háztartások költségvetési korlátjának, elsôsorban a nyugdíjrendszer ösztönzőinek a pontosabb, a háztartások viselkedésének árnyaltabb megjelenítésével tovább javítható.

A nyugdíjrendszer már most is tartalmaz olyan elemeket (például degresszió a nyugdíjak kezdô értékének kiszámításánál), melyek korosztályokon belül újraosztják a jövedelmeket. A későbbiekben csökkenő helyettesítési arány esetén egyre fontosabb lesz az alapjövedelem, illetve a nyugdíjjóváírás bevezetése, amely még lényegesebbé teszi, hogy a gazdaságban ne csak a korosztályok közötti, hanem a korosztályokon belüli heterogenitást is megjelenítsük. Ezzel tanulmányozhatóvá válik a társadalombiztosítási nyugdíjrendszer korosztályokon belüli újraelosztó szerepe, illetve ennek ösztönző hatásai.

A háztartások reakciói között kiemelendô a munkakínálat, melynek megjelenítési módjai a különbözô Auerbach-Kotlikoff-féle szimulációkban számottevô eltéréseket mutatnak. Imrohorglu et al. [1995] gazdaságában például a munkakínálat rögzített, Imrohoroglu et al. [1999] esetén viszont a foglalkoztatottság és munkanélküliség állapota közötti átmenet exogén Markov-folyamatot követ. A korábban ismertetett modellekben (pl. Fehr [2000]) a munkakínálat endogén, de - hasonlóan ehhez a tanulmányhoz - nem tesznek különbséget az intenzív (foglalkoztatottak által ledolgozott órák) és extenzív (foglalkoztatottság) határon hozott munkakínálati döntések között. Börsch-Supan, Ludwig [2010] tanulmányában egy háztartás exogén hányada foglalkoztatott, viszont ók dönthetnek afelől, hogy hány órát dolgozzanak. Más makromodellekben (pl. Sánchez Martín [2010], Fehr, Kallweit, Kindermann [2010]) csak az összes munkaóráról döntenek, viszont egy bizonyos időszakban, a korai nyugdíjkorhatár és a törvényes nyugdíjkorhatár között meghatározhatják nyugdíjbavonulásuk időpontját. Vannak olyan megközelítések is, ahol szintén döntenek a nyugdíjbavonulás időpontjáról, de a munkakínálat az extenzív és intenzív határon is külön-külön endogén (pl. Imrohoroglu és Kitao [2010], Erosa, Fuster, Kambourov [2011]). 
4. fejezet: Demográfiai átmenet és parametrikus nyugdíjreformok hatása a gazdasági növekedésre és a nyugdíjrendszer fenntarthatóságára

A nyugdíjreformok hosszú távon a háztartások olyan döntéseit is befolyásolhatják, melyeket a modell jelenleg exogén változóként kezel. Az egyik ilyen csatorna az, hogy a nyugdíjreformok közvetlenül visszahatnak a demográfiai folyamatokra azáltal, hogy a háztartások termelékenységi döntését módosítják. ${ }^{20}$ Ennek iránya azonban nem egyértelmú. Becker és Barro [1988] megközelítése szerint a gyermekvállalás "fogyasztási" döntés, a szülóknek öröme, hasznossága származik a gyereknevelésból. Ebból az következik, hogy egy szigorító nyugdíjreform, amely az életpályajövedelmek jelenértékét csökkenti, a szülők fogyasztásával együtt csökkenti a termékenységet is. Boldrin, De Nardi és Jones [2005] azonban a gyerekek "öregkori biztonsághoz" való hozzájárulását emeli ki, így a gyermekválllalás inkább "beruházási" döntés. Ebben az esetben a csökkenô nyugdíjak pótlására megtakarításaik növelése mellett növekvő gyermekvállalással is válaszolhatnak. Billari és Galasso [2009] olasz nyugdíjreformokat természetes kísérletként használva empirikus vizsgálatokat folytat, és a kettő közül a második, "beruházási" elméletet támogatja az eredményeivel. Modellünkben a háztartások termelékenysége egy exogén kvadratikus ívet követ, hosszú távon azonban a demográfiai folyamatok és a nyugdíjrendszer reformjai befolyásolhatják a humán tóke beruházát is. A demográfiai átmenet során a fizikai tôke csökkenô bérleti díja a háztartásokat nagyobb humán tóke beruházásra ösztönözheti. Ez a reakció kedvezően hathat a nyugdíjrendszer pillanatnyi egyenlegére és az egy fơre jutó GDP növekedésére is, tehát tovább enyhíthetik a demográfiai átmenet kedvezôtlen hatásait. Amennyiben a szigorító parametrikus nyugdíjreformoknak köszönhetôen a háztartások idôs korukban kevesebb nyugdíjra számíthatnak, nemcsak munkakínálatuk nagyobb mennyiségével, hanem annak jobb minôségével is reagálhatnak a humán tôke beruházásaik révén. Ugyanakkor ha a nyugdíjreform a járulékok emelését jelenti, akkor ezzel ellentétes hatást várhatunk (lásd pl. Vogel, Ludwig, Börsch-Supan [2012]). Szintén exogén változóként kezeli a dolgozat a nettó migrációt, pedig a nyugdíjrendszer reformjai visszahathatnak ezekre a folyamatokra is. A migrációt nyilvánvalóan egyéb, például kulturális tényezők is befolyásolják, de a gazdasági tényezők szerepe meghatározó. A migráció alapvetô közgazdasági modelljei (például Harris és Todaro [1970]) szerint egy

\footnotetext{
${ }^{20} \mathrm{Ez}$ abban az esetben is bekövetkezhet, ha a nyugdíjkifizetési szabályok explicit módon nem tartalmazzák a gyermekszámot. Azoknak a nyugdíjrendszereknek a modellezéséról, amelyek gyermekszámtól függó nyugdíjat tartalmaznak, lásd például Regós [2015] írását.
} 
háztartás akkor vándorol be $A$ országból $B$ országba, ha a migráció költségeit is figyelembe véve a várható életpálya-jövedelmeinek jelenértéke magasabb $B$ országban, mint $A$-ban $2^{212}$ Adott aktív életpályakereset mellett a kevésbé nagyvonalú nyugdíjrendszer csökkenti az életpálya-jövedelmek jelenértékét, ezért ceteris paribus ösztönzóleg hat a kivándorlásra, és visszafogja a bevándorlást.

\footnotetext{
${ }^{21}$ Alacsony vagyonú és jövedelmú háztartásoknál a hitelkorlát megakadályozhatja a migrációs költségek megfinanszírozását, még ha a feltétel fönn is áll.

${ }^{22} \mathrm{~A}$ lehetséges migránsok várható jövedelmek alapján mérlegelnek, tehát figyelembe veszik a foglalkoztatási esélyeket is.
} 


\section{5. fejezet}

\section{Befejezés}

Az értekezés három önálló tanulmányból áll, melyek témáját összeköti, hogy mindegyik a hosszú távú munka- és tôkekínálatot befolyásoló tényezókrôl, és azok makrogazdasági következményeiról fogalmaz meg gondolatokat.

A közgazdaságtanban az ágens-alapú modellezés egyik viszonylag új alkalmazási területe a makroökonómia. Minden makromodellnek, így az ágens-alapú modelleknek is, fontos része a megtakarítási döntések kezelése. A megtakarítások nem tartoznak az ágens-alapú mikroökonómiai modellek népszerú alkalmazási területei közé, ezért a makromodellezók a hagyományos megtakarítási elméletekhez nyúltak vissza, és a megtakarítási viselkedések bizonyos leegyszerúsített válfajait, amelyet viselkedési szabályként lehet felfogni, építették be modelljeikbe. A 2 fejezetben azt kérdeztük, hogy néhány népszerú megtakarítási szabály létét feltételezve egy adaptív-evolúciós megközelítésból endogén módon tudunk-e következtetni ezen szabályok relatív életképességére, illetve arra, hogy milyen társadalmi kimeneteket kapunk, amikor az egyes megtakarítási szabályok versenyeznek egymással. Három típust vezetünk be: egy prudens, egy rövidlátó, és egy a permanens jövedelem elméletnek megfelelően múködő típust. Rendkívül erôs szelekciós nyomás mellett a prudens típus egyértelmúen kiszorítja a másik kettôt. Talán furcsa módon a második legéletképesebbnek a rövidlátó típus tûnik, de már közepes szelekciós nyomásnál sem hal ki egyik típus sem. Szokásos tókehatékonyság mellett a prudens típus túl- 
beruházási tendenciát visz a gazdaságba, és a gazdaság az aranykori megtakarítási rátánál magasabbat produkál. A hitelkorlátok oldása még nagyobb túlberuházáshoz vezethet, a hitelek mennyiségének növekedése mellett a tôketulajdonosok, akik itt endogén módon alakulnak ki, mintegy kizsákmányoltatják magukat azokkal, akiknek nincs pozitív tőkejövedelmük. A hosszú távú átlagos fogyasztás szempontjából a típusok kiegyensúlyozott aránya adja a legjobb eredményt, ugyanakkor ez jóval nagyobb ingadozással jár, mint amikor csak prudens típusú háztartások léteznek.

Korai lenne a modellt az adatokkal is egybevetni. Mindenestre egy fontos üzenete a munkának az, hogy új típusú adatokat kellene használni a megtakarítások empirikus vizsgálatánál. Az emberek társadalmi lények, akik kevés dolgot csinálnak egyedül. A megtakarítást is a társadalmi kapcsolatok szükségképpen befolyásolják. A család, a baráti és munkahelyi környezet vagy a média hatása a megtakarítási viselkedésre eddig nem igazán voltak a közgazdasági elemzés témái. Nem ismert olyan tanulmány sem, amely a viselkedési típusok örökölhetőségét vizsgálná.

A 3. fejezet a magyar férfiak 1999 és 2009 közötti életciklus átlagos munkaprofiljainak és nyugdíjba vonulási jellemzóinek a bemutatását követően felvázol egy magyar adatokra kalibrált életciklus-munkakínálati modellt, és parametrikus nyugdíjreformok hatását szimulálja a segítségével. Az eredmények szerint a helyettesítési ráta csökkentése, a nyugdíjkorhatár emelése és az indexálás megváltoztatása összességében növeli az egyes képzettségi csoportok munkakínálatát, míg a nyugdíj alapját képező életpálya-átlagkeresetbe beszámító évek számának megváltozása nem jár jelentős aggregált hatással. A reformok azonban az összevont hatások mellett átcsoportosítják a munkakínálatot a korosztályok között. Hosszú távon a reformok a nyugdíjfelhalmozás életkorral fokozódó marginális ösztönzőinek a gyengülése miatt a munkakínálatot a fiatalabb korosztályok felé tolják el. A helyettesítési ráta csökkentése még a két hatás eredôjeként valamennyi korosztályban emelte a foglalkoztatást, de a korhatáremelés és az átlagolási időszak növelése csökkentette a reform előtt is dolgozó idősebb munkaképes korosztályok foglalkoztatását. Ezzel együtt a korhatáremelés újabb, korábban egyáltalán nem dolgozó korosztályt vont be a munkaerőpiacra, ezért a 61-65 éves, illetve összességében az 56-65 éves 
korosztály foglalkoztatása jelentősen nőtt. A másik három reformtól eltérően az árkövetô indexálás bevezetése minden korosztályban azonos mértékben növelte a foglalkoztatást, hiszen a bevezetése a marginális ösztönzóket nem érintette.

A munka csak egy kezdeti lépésnek tekinthető az életciklus-munkakínálat és a nyugdíjrendszer kapcsolatának vizsgálatában, ugyanis a modell még nem képes a foglalkoztatási profilok idôsebb korban megfigyelhetô meredek, képzettségi csoportonként eltérô mértékú visszaesését reprodukálni. Az idôskori munkakínálat erôteljesebb visszaesését támogatná, ha a munkakínálati döntésen belül elkülönülne az alkalmazkodás intenzív és extenzív határa, amit például a munkaerôpiaci részvétel esetén felmerülő fix költség bevezetésével lehet megoldani. Fontos tényező még a nyugdíjrendszer részletesebb leírása: a nettó keresetek és a nyugdíjak közötti kapcsolat gyengítése a degresszivitás és a minimális nyugdíj bevezetésével és a korai nyugdíjba vonulás lehetôsége eltérố nyugdíjba vonulási és foglalkoztatottsági mintázatokat eredményezhet a különbözô képzettségi csoportokban. Az egészségi állapot, a munkaképesség romlása korral szintén olyan tényezők, amelyek idősebb munkavállaló korban az alacsonyabb aktivitást indokolhatják, ezért szükségesnek tartjuk a megjelenítésüket.

A 4. fejezet másdik része megvizsgálja, hogya demográfiai átmenet hogyan hat a nyugdíjkassza GDP-arányos egyenlegére és a makrováltozók pályájára, illetve meghatározza, hogy egyes parametrikus nyugdíjreformok hogyan módosítják a hatásokat. Elemzési keretül egy kis nyitott gazdaság kockázati prémiumot, együttélő korosztályokat tartalmazó neoklasszikus növekedési modellje szolgál, ahol a gazdasági szereplők munkakínálata és megtakarítása reagál a nyugdíjrendszer ösztönzőire.

A szimuláció során a 2006 és 2070 közötti időszakban a magyar népesség szerkezeti átrendeződése, a munkaképes korú és jelentős vagyonnal rendelkező háztartások arányának csökkenése önmagában számottevően mérsékli a hatékony munkakínálatot, a hatékony fốre jutó tókekínálatot, és az egy fốre jutó GDP-t a technikai haladás által indokolt emelkedéshez képest. Egy dekompozíciós eljárás azonban megmutatja, hogy a kedvezőtlen szerkezeti átalakulások okozta elmaradást mérsékli, hogy a háztartások, reagálva a történtekre növelik munkakínálatukat és több vagyont 
halmoznak föl. A többletmegtakarítás a külső pozíciót is javítja, a mérséklődő kockázati prémium hatására csökkenő kamatok pedig beruházásokat indukálnak, tôkeintenzívebbé teszik a termelést, ez pedig a reálbérekre is kedvezően hat. Az öregedô társadalomban változatlan nyugdíjparaméterek mellett jelentôsen nônek a GDP-arányos nyugdíjkiadások, a tb-nyugdíjkassza egyenlege 2070-ig a GDP több, mint $10 \%$-ával romlik.

Az "egyszerü" parametrikus reformok hosszabb távon megállítani nem, csak lassítani tudják a GDP-arányos kiadásoknak és a tb-hiánynak az emelkedését. A helyettesítési ráta csökkentése, a korhatáremelés és az árindexálás együttes bevezetése az azonnali egyenlegjavító hatása is csak 2041-45-ig képes megtartani a nyugdíjrendszer egyenlegének kiegyensúlyozottságát, járulékemeléssel kiegészülve azonban már egészen 2070-ig képes ellensúlyozni a demográfiai átmenet egyenlegrontó hatását, kezdetben pedig számottevő javuláshoz vezet. Ennek ára, hogy az egyes korosztályok 60 éves korban várt nyugdíjainak jelenértéke a reálbérhez képest minden esetben csökken. Az "összetett" reformok esetén a csökkenés minden érintett korosztály számára számottevô, az alappályához képest akár 36-42\%-os veszteséget is jelenthet, az idősek jelentôs relatív elszegényedését okozva. A járulékemeléstôl eltekintve a reformok ösztönzik a háztartások munka- és tókekínálatát, és együttes végrehajtásuk hatására az effektív munkaórák száma, a GDP, a fogyasztás és a háztartások vagyona nagyobb lehet 2066-70-re az alappálya értékeinél, és a GDP-arányos külső adósság is mérséklődhet.

Az írásban igyekeztünk kiemelni, hogy a demográfiai átmenet, illetve a parametrikus nyugdíjreformok hatásainak értékelésénél fontos figyelembe venni, hogy a háztartások munka- és tókekínálatukkal reagálnak a változásokra. A reakciók megjelenítése a modellben azonban egyelöre még nem elég pontos, ahhoz a háztartások költségvetési korlátjának, elsôsorban a nyugdíjrendszer ösztönzőinek a pontosabb, a háztartások viselkedésének az árnyaltabb megjelenítését tartjuk szükségesnek. A fejezet záró része megemlíti, hogy a munka- és tókekínálati reakciók mellett hosszú távon a háztartások termékenységi, humántőke-beruházási és migrációs dönétseikkel is reagálhatnak a nyugdíjrendszer reformjaira, ezért a jövôben fontosnak tartjuk a megjelenítésüket. Egy másik továbblépési irány, ha a gazdaságban nem 
csak a korosztályok közötti, hanem a korosztályokon belüli heterogenitást is megjelenítjük, és így tanulmányozhatóvá válik a társadalombiztosítási nyugdíjrendszer korosztályokon belüli újraelosztó szerepe is. 
Hosszú távú munkakinálat, tôkekínálat és makrogazdasági hatásaik 


\section{6. fejezet}

\section{Hivatkozások}

- Acemoglu, D., Johnson, S., Robinson, J. [2004]: Institutions as the Fundamental Cause of Long-Run Growth. NBER Working Papers Working Paper 10481. http://dx.doi.org/10.1016/S1574-0684(05)01006-3

- Aiyagari, S., R. [1994]: Uninsured Idiosyncratic Risk and Aggregate Saving. Quarterly Journal of Economics, Vol. 109(3), pp. 659-684. http://dx.doi. $\operatorname{org} / 10.2307 / 2118417$

- Auerbach, A.J., L.J. Kotlikoff [1987]: Dynamic Fiscal policy, Cambridge University Press, Cambridge.

- Arifovic, J. [2000]: Evolutionary algorithms in macroeconomic models. http: //dx.doi.org/10.1017/S1365100500016059 Macroeconomic Dynamics 4.03 (2000): 373-414.

- Augusztinovics M., Gál R., Matits Á. Máté L., Simonovits A., Stahl J. [2002]: A magyar nyugdíjrendszer az 1998-as reform elótt és után. Közgazdasági Szemle, 6. sz.

- Augusztinovics M. [2005]: Népesség, foglalkoztatottság, nyugdíj. Közgazdasági Szemle, LII. évf., 2005 május (429-447. o.) 
- Augusztinovics M., Köllő J. [2007]: Munkapiaci pálya és nyugdíj, 1970-2020. Közgazdasági Szemle, LIV. évf., 2007. június (529-559. o.)

- Augusztinovics M., Gyombolai M., Máté L. [2008]: Járulékfizetések és nyugdíjjogosultság 1997-2006. Közgazdasági Szemle, LV. évf., 2008. július-augusztus (665-689. о.)

- Azariadis, C., Stachurski, J. [2005]: Poverty Traps. In: Aghion, P., Durlauf, S. szerk. [2005]: Handbook of Economic Growth. Elsevier, edition 1, volume 1, December. http://dx.doi.org/10.1016/S1574-0684(05)01005-1

- Bálint M., Köllő J., Molnár Gy. [2010]: Nyugdíjjogszerzés a teljes életpályára vonatkozó adatok alapján. Jelentés a KSH-ONYF adatfelvételrôl. In: Holtzer P. (szerk.) [2010]: Jelentés A Nyugdíj és Időskor Kerekasztal tevékenységéról. Miniszterelnöki Hivatal.

- Benczúr P. [2007]: Az adókulcsok hatása a különböző gazdasági szereplő viselkedésére - irodalmi összefoglaló. Közgazdasági Szemle, LIV. évf., 2007. február (125-141. o.)

- Benczúr P., Kátay G., Kiss Á. [2012]: Assessing changes of the Hungarian tax and transfer system: A general-equilibrium microsimulation approach. MNB Working Papers 7.

- Bewley, T. F. [1980]: The permanent income hypothesis and long-run economic stability. Journal of Economic Theory, 22(3), p. 377-394. http: //dx.doi.org/10.1016/0022-0531(80)90049-6

- Billari, C., F, Galasso, V. [2008]: What Explains fertility? Evidence from Italian pension reforms. IGIER (Innocenzo Gasparini Institute for Economic Research), Bocconi University Working Papers number 343.

- Blanchard, O. J. [1985]: Debt, Deficits and Finite Horizon. Journal of Political Economy, 93, pp. 223-247. http://dx.doi.org/10.3386/w1389

- Blundell, R., Bozio, A., Laroque, G. [2011]: Extensive and intensive margins of labour supply: working hours in the US, UK and France. IFS Working 
Hivatkozások

Papers W11/01, Institute for Fiscal Studies. p 1-80. http://dx.doi.org/ 10.1920/wp. ifs.2011.1101

- Börsch-Supan, A., H., Ludwig, A. [2010]: Old Europe Ages: Reforms and Reform Backlashes. NBER Working Paper Series 15744. http://dx.doi. org/10.3386/w15744

- Brenner, T. [2006]: Agent learning representation: advice on modelling economic learning. Handbook of computational economics 2: 895-947.

- Brock, W., A., Hommes, C. [1997]: A Rational Route to Randomness. Econometrica, vol. 65, issue 5, 1059-1096.

- Carroll, C. D., Summers, L. H. [1991]: Consumption growth parallels income growth: some new evidence. In National saving and economic performance (pp. 305-348). University of Chicago Press.

- Carroll, C., D. [1996]: Buffer-stock saving and the life cycle/permanent income hypothesis. No. w5788. National Bureau of Economic Research. http://dx.doi.org/10.3386/w5788

- Campbell, J. Y., Mankiw, N. G. [1989]: Consumption, income and interest rates: Reinterpreting the time series evidence. In NBER Macroeconomics Annual 1989, Volume 4 (pp. 185-246). MIT Press.

- Chetty, R., Guren, A., Manoli, D., Weber, A. [2011]. Are Micro and Macro Labor Supply Elasticities Consistent? A Review of Evidence on the Intensive and Extensive Margins. American Economic Review, 101(3): 471-75. http: //dx.doi.org/10.1257/aer.101.3.471

- Cseres-Gergely Zs. [2007]: Inactivity in Hungary - the impact of the pension system. Budapest Working Papers on the Labour Market 2007/1.

- Cseres-Gergely [2015]: A 2000-es évek magyarországi nyugdíjkorhatár-emeléseinek azonnali hatása az érintett nők munkavállalására 652-673. Közgazdasági Szemle, LXII. évfolyam, 2015. június 652-673. o. 
- De la Croix, D., Pierrard, O., Sneesens, H., R. [2012]: Aging and pensions in general equilibrium: Labor market imperfections matter. Journal of Economic Dynamics and Control. http://dx.doi.org/10.1016/j.jedc.2012. 06.011.

- Deissenberg, C., Van Der Hoog, S., Dawid, H. [2008]: EURACE: A massively parallel agent-based model of the European economy. Applied Mathematics and Computation, 204(2), 541-552. http://dx.doi.org/10.1016/j.amc. 2008.05 .116

- Delli Gatti, D., Desiderio, S., Gaffeo, E., Cirillo, P., Gallegati, M. [2011]: Macroeconomics from the Bottom-up. New economic windows. Springer.

- Diamond, P. [1965]: National Debt in a Neoclassical Growth Model. American Economic Review, 55, pp. 1126-1150. http://dx.doi.org/10.2307/ 1809231

- Dickey, D. A., Fuller, W. A. [1979]: Distribution of the estimators for autoregressive time series with a unit root. Journal of the American Statistical Association 74 (366a): 427-431. http://dx.doi.org/10.1080/01621459. 1979.10482531

- Dobrescu, L. I., Kotlikoff, L., J., Motta, A. [2012]: Why aren't developed countries saving?. European Economic Review 56.6 1261-1275. http://dx. doi.org/10.3386/w14580

- Dosi, G., Fagiolo, G., Napoletano, M., Roventini, A. [2013]: Income distribution, credit and fiscal policies in an agent-based Keynesian model. Journal of Economic Dynamics and Control, 37(8), 1598-1625.

- Duffy, J. [2006]: Agent-based models and human subject experiments. Handbook of computational economics 2: 949-1011.

- Erdős, P., Rényi, A. [1959]: On Random Graphs. Publicationes Mathematicae 6: 290-297. 
Hivatkozások

- Erosa, A., Fuster, L., Kambourov, G. [2011a]: A Theory of Labor Supply Late in the Life Cycle: Social Security and Disability Insurance. Mimeo, University of Toronto.

- Erosa, A., Fuster, L., Kambourov, G. [2011b]: Towards a Micro-Founded Theory of Aggregate Labor Supply. Mimeo, University of Toronto.

- Eurostat [2012]: Taxation trends in the European Union. Data for the EU Member States, Iceland and Norway. Eurostat Statistical Books.

- Evans, G. W., S. Honkapohja [1999]: Learning Dynamics, in: Handbook of Macroeconomics I. Vol. A, Ch. 7., eds.: J.B. Taylor-M. Woodford, Elsevier.

- Fehr, H. [2000]: Pension Reform During the Demographic Transition. Scandinavian Journal of Economics, 102, pp. 419-443. http://dx.doi.org/10. 1111/1467-9442.03206

- Fehr, H., Halder, G., Jokisch, S. [2003]: A Simulation Model for the Demographic Transition in Germany. Data Requirements, Model Structure and Calibration. Würzburg Economic Papers No. 48.

- Fehr, H., Halder, G., Jokisch, S. [2003]: The Developed World's Demographic Transition - The Roles of Capital Flows, Immigration, and Policy. NBER Working Paper No. 10096. http://dx.doi.org/10.3386/w10096

- Fehr, H., Halder, G., Jokisch, S., Kotlikoff, L., J. [2005]: Will China Eat Our Lunch or Take Us Out to Dinner? Simulating the Transition Paths of the U.S., EU, Japan, and China. NBER Working Paper No. 11668. http://dx.doi.org/10.3386/w11668

- Fehr, H., Kallweit M., Kindermann F. [2010]: Pension Reform with Variable Retirement Age - A Simulation Analysis for Germany. Network for Studies on Pensions, aging and Retirement. Discussion Paper 02/2010 - 013 http: //dx.doi.org/10.2139/ssrn.1625789

- Fehr, H., Kallweit M., Kindermann F. [2011]: Should pensions be progressive? Yes, at least in Germany! Netspar Discussion Papers 2011-010. http://dx. doi.org/10.2139/ssrn.1809699 
- Feldstein, M. [1995]: Social Security and Saving: New Time Series evidence. NBER Working Paper 5054. http://dx.doi.org/10.3386/w5054

- Fisher, I. [1930]: The Theory of lnterest, Macmillan, New York, 1930

- French, E. [2005]: The effects of health, wealth and wages on labor supply and retirement behavior. Review of Economic Studies, 72, 395-427. http: //dx.doi.org/10.1111/j.1467-937X.2005.00337.x

- Fudenberg, D., Levine, D. K. [2006]: A dual-self model of impulse control. The American Economic Review. p. 1449-1476. http://dx.doi.org/10. $1257 /$ aer.96.5.1449

- Gibbons, J. D. [1985]: Nonparametric Statistical Inference. New York: Marcel Dekker Inc., second ed.

- Gilbert, G., N. [2008]: Agent-based models. No. 153. Sage.

- Greenwood, J., Vandenbroucke, G. [2005]: Hours worked: Long-Run Trends. NBER Working Paper 11629. p. 1-17. http://dx.doi.org/10.3386/ W11629

- Grazzini, J. [2012]: Analysis of the Emergent Properties: Stationarity and Ergodicity Journal of Artificial Societies and Social Simulation 15 (2) 7

- Gruber, J., Wise, D. A. [2002], Social Security Programs and Retirement Around the World: Microestimation, NBER Working Paper 9407. http: //dx.doi.org/10.3386/w9407

- Hablicsek L. [2010]: Társadalmi-demográfiai előreszámítások a nyugdíjrendszer átalakításának modellezéséhez. Elöreszámítási rendszer és adatbázis. In: Holtzer P. (szerk.) [2010]: Jelentés A Nyugdíj és Időskor Kerekasztal tevékenységérôl. Miniszterelnöki Hivatal.

- Hall, R., E., Mishkin, F., S. [1982]: The Sensitivity of Consumption to Transitory Income: Estimates from Panel Data on Households. Econometrica, 50(2), p. 461-81. http://dx.doi.org/10.3386/w0505 
Hivatkozások

- Hansen, G., D. [1985]: Indivisible labor and the business cycle. Journal of Monetary Economics Volume 16, Issue 3, November 1985. p. 309-327. http://dx.doi.org/10.1016/0304-3932(85)90039-X

- Harris, J., R., Todaro, M., P. [1970]: Migration, Unemployment and Development: A Two-Sector Analysis. American Economic Review 60 (1): 126 Ü142

- Heath, B., Hill, R., Ciarallo, F. [2009] A Survey of Agent-Based Modeling Practices (January 1998 to July 2008) Journal of Artificial Societies and Social Simulation 12 (4) 9.

- Holtzer P. szerk. [2010]: Jelentés a Nyugdíj és Időskor Kerekasztal tevékenységérôl. Miniszterelnöki Hivatal.

- Horváth Gy. [2010]: A hatásvizsgálat mikroszimulációs modellje. In: Holtzer P. szerk. [2010]: Jelentés a Nyugdíj és Időskor Kerekasztal tevékenységéról. Miniszterelnöki Hivatal.

- Human Mortality Database. University of California, Berkeley (USA), and Max Planck Institute for Demographic Research (Germany). Elérhetőség: www.mortality.org Letöltés dátuma: 2014.04.01.

- Imrohoroglu, A., Imrohoroglu, S., Joines, D., H. [1995]: A life cycle analysis of social security, Economic Theory, 6, p. 83-114. http://dx.doi.org/10. 1007/BF01213942

- Imrohoroglu, A., Imrohoroglu, S., Joines, D., H. [1999]: Social security in an overlapping generations economy with land, Review of Economic Dynamics, 2, p. 638-665. http://dx.doi.org/10.1006/redy.1999.0066

- Imrohoroglu, S., Kitao S. [2010]: Social Security, Benefit Claiming, and Labor Force Participation: A Quantitative General Equilibrium Approach. Federal Reserve Bank of New York Staff Reports no 436. http://dx.doi.org/10. $2139 /$ ssrn. 1567542

- Kátay G. szerk. [2009]: Az alacsony aktivitás és foglalkoztatottság okai és következményei Magyarországon. MNB-tanulmányok-79. 
- Keane, M. P. [2011]: Labor Supply and Taxes: A Survey. Journal of Economic Literature 2011, 49:4, p. 961-1075. http://dx.doi.org/10.1257/jel. 49.4 .961

- Kovács E. [2008]: A nyugdíjparaméterek nemzetközi összehasonlítása. Biztosítási Szemle 3., p. 26-37.

- Krugman, P. [1991]: Increasing Returns and Economic Geography, Journal of Political Economy, University of Chicago Press, vol. 99(3), p. 483-99, June. http://dx.doi.org/10.1257/aer.99.3.561

- Kumhof, M., Laxton, D. [2009]: Fiscal Deficits and Current Account Deficits. IMF Working Paper No. 09/237.

- Laibson, D. [1997]: Golden Eggs and Hyperbolic Discounting. Quarterly Journal of Economics, 112(2), p. 443-477. http://dx.doi.org/10.1162/ 003355397555253

- Madrian, B. C., Shea, D. F. [2001]: The power of suggestion: Inertia in 401 (k) participation and savings behavior. The Quarterly Journal of Economics, 116(4), p. 1149-1187. http://dx.doi.org/10.1162/003355301753265543

- Magnani G. [2011]: A general equilibrium evaluation of the sustainability of the new pension reforms in Italy. Research in Economics 65 p. 5 Ú35. http://dx.doi.org/10.1016/j.rie.2010.02.001

- Manoli, D., Mullen, K., Wagner, M. [2011]: Policy Variation, Labor Supply Elasticities and a Structural Model of Retirement. Mimeo UCLA.

- Modigliani, F., Brumberg, R. [1954]: Utility Analysis and the Consumption Function. In Post-Keynesian Economics. Edited by K. Kurihara. New Brunswick, N.J.: Rutgers University Press, 1954. p. 338-436.

- Murphy, K., M., Shleifer, A., Vishny, R., W. [1989]: Industrialization and the Big Push. The Journal of Political Economy. Vol 97, Issue 5. p. 1003-1026. http://dx.doi.org/10.3386/w2708 
Hivatkozások

- Nishiyama, S. and K. Smetters [2007]: Does social security privatization produce efficiency gains? Quarterly Journal of Economics 122(4), p. 1677-1719. http://dx.doi.org/10.3386/w11622

- OECD [2013]: Pensions at a Glance 2013. OECD and G20 Indicators. http: //dx.doi.org/10.1787/pension_glance-2013-en

- OECD [2014]: Key Tables from OECD. OECD.

- Orbán G., Palotai D. [2005]: A magyar nyugdíjrendszer fenntarthatósága. MNB-tanulmányok 40.

- Orbán G., Palotai D. [2006]: Kihívások előtt a magyar nyugdíjrendszer. MNB-tanulmányok 55.

- Országos Nyugdíjbiztosítási Főigazgatóság [2011]: 1996-2008. közötti új rokkantsági nyugdíjasok fóbb adatainak vizsgálata, Budapest.

- Országos Nyugdíjbiztosítási Fóigazgatóság [2011]: Központi Elektronikus Nyilvántartási Rendszer.

- Piketty, T. [2014] Capital in the Twenty-first Century. Harvard University Press.

- Rocha, R. Vittas, D. [2002]: The Hungarian Pension Reform: A Preliminary Assessment, Feldstein and Siebert, eds., p. 365-400.

- Rebelo, S. [1991]: Long-Run Policy Analysis and Long-Run Growth. The Journal of Political Economy, Vol. 99, No. 3 (Jun., 1991), p. 500-521. http://dx.doi.org/10.1086/261764

- Regős, G. [2015]: Can Fertility be Increased With a Pension Reform? Ageing International June 2015, Volume 40, Issue 2, pp 117-137 http://dx.doi. org/10.1007/s12126-014-9206-y

- Romer, P., M. [1990]: Endogenous Technological Change. The Journal of Political Economy, Vol. 98, No. 5, Part 2. p. 71-102. http://dx.doi.org/ $10.3386 / w 3210$ 
- Rust, J.,Phelan C. [1997]: How Social Security and Medicare Affect Retirement Behavior In a World of Incomplete Markets. Econometrica 65 (4), p. 781-831.

- Samuelson, P. A. [1958]: An Exact Consumption-loan Model of Interest, with or without the Social Contrivance of Money. Journal of Political Economy, 66, p. 467-482. http://dx.doi.org/10.1086/258100

- Sanchez Martin, A. R. [2010]: Endogenous retirement and public pension system reform in Spain. Economic Modelling 27 (2010) p. 336-349. http: $/ /$ dx.doi.org/10.1016/j.econmod.2009.09.013

- Schmitt-Grohé, S., Uribe, M. [2003]: Closing small open economy models. Journal of International Economics 61 (2003) 163Ü185. http://dx.doi. org/10.1016/S0022-1996(02)00056-9

- Schmitt-Grohé, S., Uribe, M. [2015]: How Important Are Terms Of Trade Shocks? NBER Working Paper No. 21253. http://dx.doi.org/10.3386/ w21253

- Schooler, L. J., Hertwig, R. [2005]: How Forgetting Aids Heuristic Inference. Psychological Review, 112(3), 610-628. http://dx.doi.org/10.1037/ 0033-295X.112.3.610

- Simonovits A. [2003]: Modeling Pension Systems, Palgrave Macmillan, Houndmills, UK.

- Simonovits A. [2009a]: Hungarian Pension System and its Reform. MTA KTI Discussion Papers 2011/11.

- Simonovits A. [2009b]: Népességöregedés, tb-nyugdíj és megtakarítás - parametrikus nyugdíjreformok. Közgazdasági Szemle, LVI. évf., 2009. április 297-321. o.

- Simonovits A. [2011]: International Economic Crisis and the Hungarian Pension Reform. MTA KTI Discussion Papers 2009/8. 
- Simonovits A. [2012]: Optimális lineáris adó- és nyugdíjrendszer rugalmas munkakínálat esetén, Szigma, 43. évf. 1Ū2. sz. 1Û14. o.

- Solow, R., M. [1956]: A Contribution to the Theory of Economic Growth. The Quarterly Journal of Economics, Vol. 70, No. 1. (Feb., 1956), p. 65-94. http://dx.doi.org/10.2307/1884513

- Tesfatsion, L. [2001]: Introduction to the Special Issue on Agent-Based Computational Economics. Journal of Economic Dynamics and Control 25(3-4), 281-293.

- Tesfatsion, L. [2006]: Agent-Based Computational Economics: A Constructive Approach to Economic Theory, in: Tesfatsion.L. - K. L. Judd (eds.) Handbook of Computational Economics, Vol. 2, Ch. 16., Elsevier. 831-880.

- Vogel, E., Ludwig, A., Börsch-Supan, A. [2012]: Aging and Pension Reform: Extending the Retirement Age and Human Capital Formation. SAFE Working Paper No. 82. http://dx.doi.org/10.2139/ssrn.2553236

- Wallenius, J. [2013]: Social Security and Cross-Country Differences in Hours: A General Equilibrium Analysis. Journal of Economic Dynamics and Control 37 (2013), p. 2466-2482.

- Yaari, M. E. [1965]: Uncertain Lifetime, Life Insurance, and the Theory of the Consumer. Review of Economic Studies, 32(2), p. 137-150. http: $/ /$ dx.doi.org/10.2307/2296058 
Hosszú távú munkakínálat, tôkekinálat és makrogazdasági hatásaik 


\section{7. fejezet}

\section{Saját publikációk a témában}

- Major K., Varga G. [2013]: Parametrikus nyugdíjreformok és életciklusmunkakínálat. Közgazdasági Szemle LX. évf., 2013. november 1169-1207. o.

- Varga G. [2014a]: Demográfiai átmenet, gazdasági növekedés és a nyugdíjrendszer fenntarthatósága. Közgazdasági Szemle LXI. évf., 2014. november 1279-1318. o.

- Varga G. [2014b]: Demográfiai átmenet, parametrikus nyugdíjreformok és munkakínálat az együttélő korosztályok modelljeiben. Külgazdaság LVIII. évf., 2014/9-10. 70-95. o.

- Varga G., Vincze J. [2015a]: Ants and crickets: arbitrary saving rates in an agent-based model with infinitely lived agents. Institute of Economics, Centre for Economic and Regional Studies, Hungarian Academy of Sciences. Discussion papers. MT-DP - 2015/4.

- Varga G., Vincze J. [2015b]: Megtakarítási típusok: egy adaptív-evolúciós megközelítés. Magyar Tudományos Akadémia Közgazdaság- és Regionális Tudományi Kutatóközpont, Közgazdaság-tudományi Intézet. Múhelytanulmányok. MT-DP - 2015/43. 
Hosszú távú munkakínálat, tôkekinálat és makrogazdasági hatásaik 


\section{8. fejezet}

\section{Függelék}

\section{F.1. Ábrák, táblázatok}

8.1. ábra. A férfiak átlagos egy főre jutó munkaórái, foglalkoztatottsági rátái és egy munkásra jutó munkaórái 1999., 2004. és 2009. években
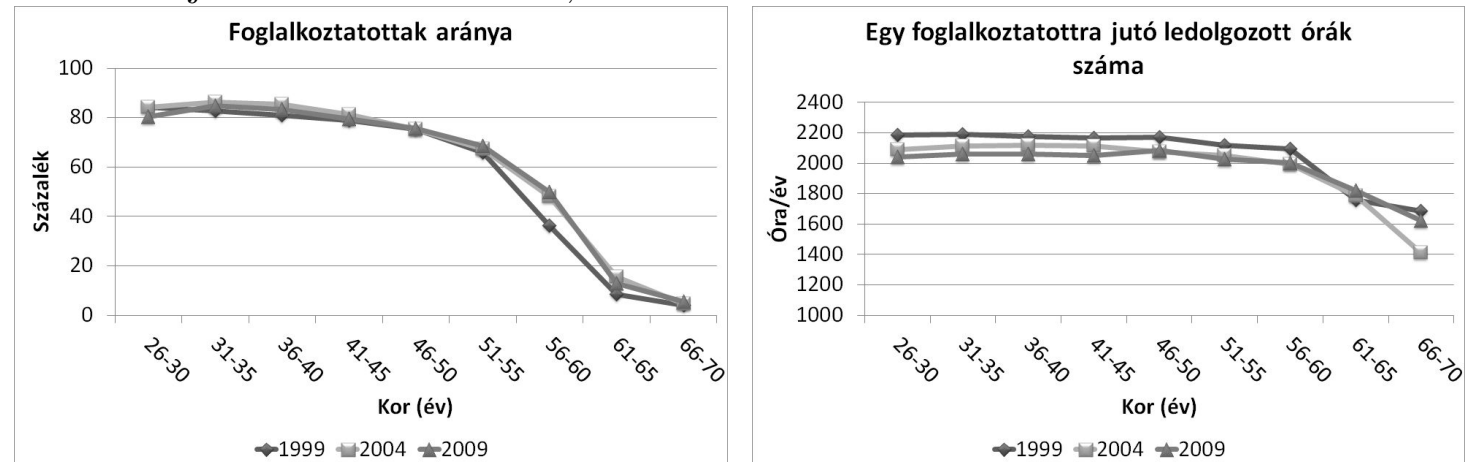

$\downarrow 1999+2004 \mp 2009$

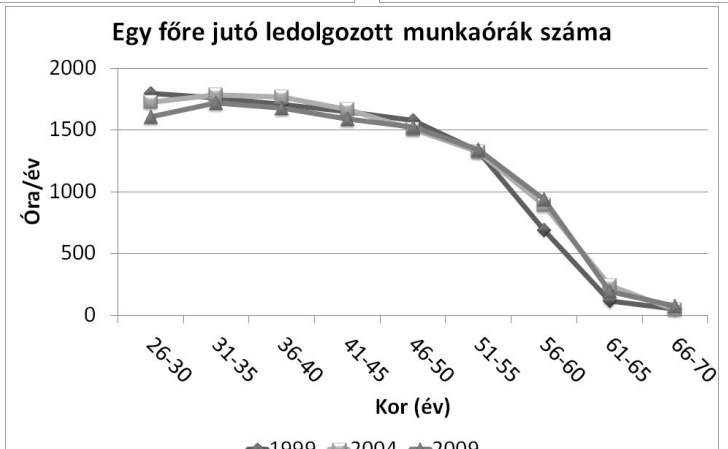

Forrás: saját számitás a KSH munkaerô-felmérése alapján 
8.2. ábra. A férfiak átlagos egy fôre jutó munkaóráinak, foglalkoztatottsági rátáinak és egy munkásra jutó munkaóráinak arányai képzettségi csoportonként 1999-2009
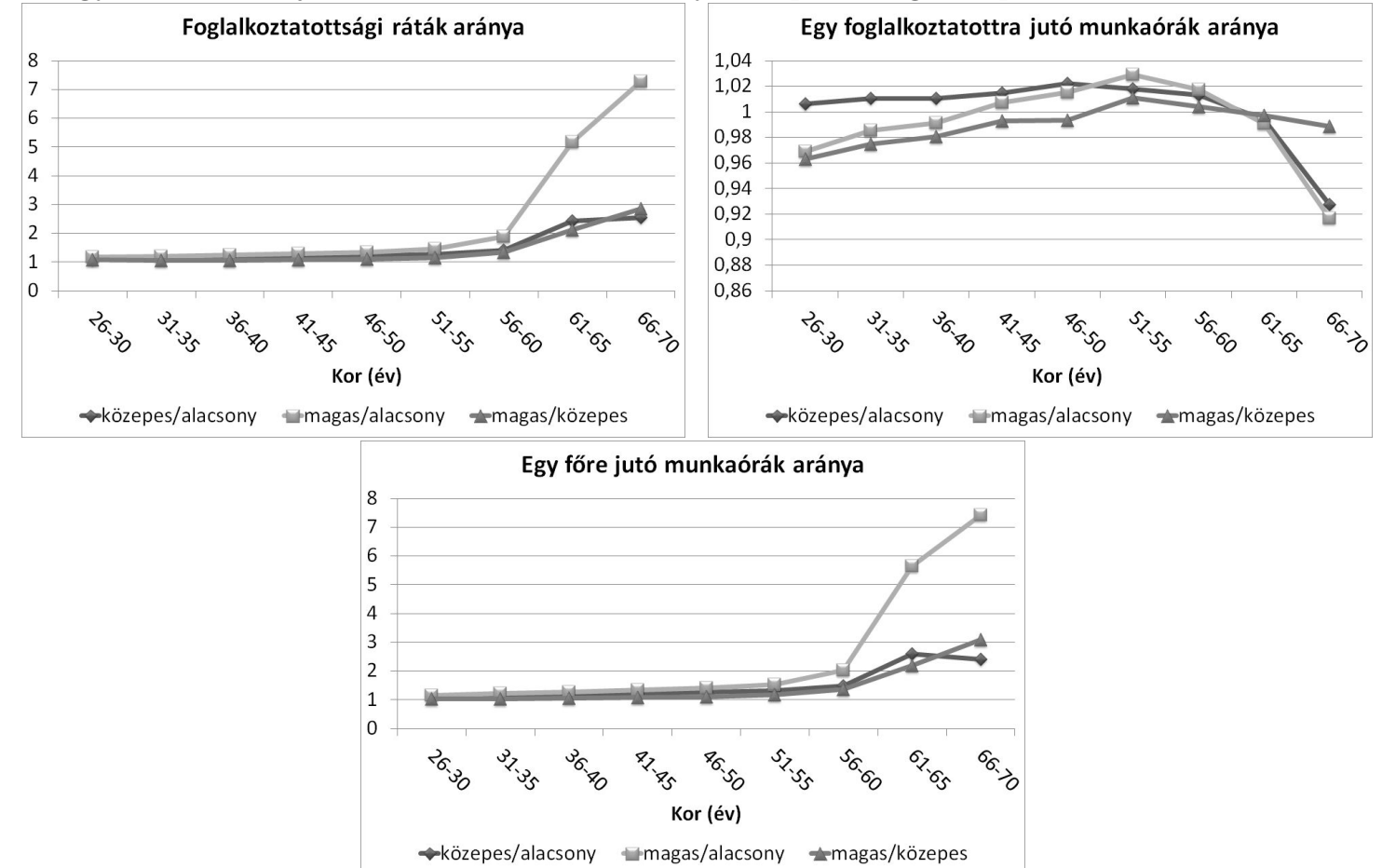

Forrás: saját számítás a KSH munkaerô-felmérése alapján

8.3. ábra. Nyugdíjas és foglalkoztatott férfiak aránya korosztályonként 1999. és 2009. években
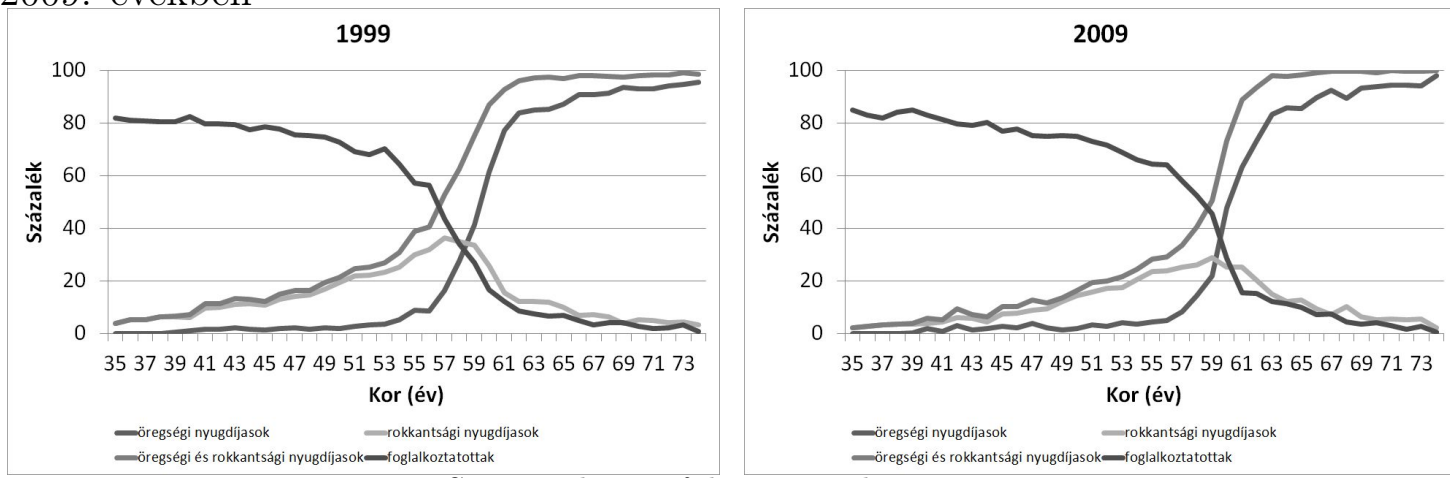

Forrás: saját számítás a KSH munkaeró-felmérése alapján 
8.4. ábra. Rokkantsági és öregségi nyugdíjba vonuló férfiak aránya korosztályonként az 1999., 2004. és 2009. években
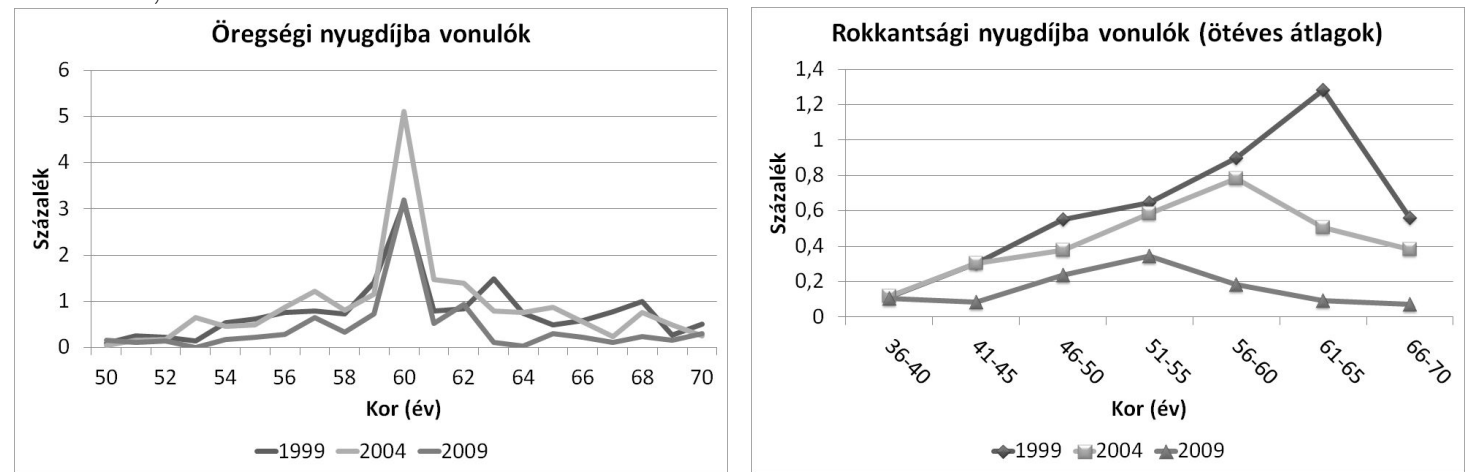

Forrás: saját számitás a KSH munkaerô-felmérése alapján

8.1. táblázat. A munkakínálat százalékos megváltozása a parametrikus nyugdíjreformok hatására az egyes korosztályokban. 3 képzettségi csoport

\begin{tabular}{|c|c|c|c|c|c|c|c|c|c|c|c|c|}
\hline \hline Koroszt. & \multicolumn{3}{|c|}{ 1. reform } & \multicolumn{3}{c|}{ 2. reform } & \multicolumn{3}{c|}{ 3. reform } & \multicolumn{3}{c|}{ 4. reform } \\
\hline & F. & K. & A. & F. & K. & A. & F. & K. & A. & F. & K. & A. \\
\hline \hline 26-30 év & 1.71 & 1.65 & 1.65 & 1.37 & 1.51 & 0.75 & -1.05 & -0.67 & -0.42 & 1.80 & 1.76 & 1.75 \\
$31-35$ év & 1.67 & 1.61 & 1.61 & 1.21 & 1.35 & 0.59 & -0.55 & -0.16 & 0.09 & 1.80 & 1.76 & 1.75 \\
$36-40$ év & 1.60 & 1.54 & 1.54 & 0.93 & 1.07 & 0.32 & -0.46 & -0.07 & 0.17 & 1.80 & 1.76 & 1.75 \\
$41-45$ év & 1.47 & 1.42 & 1.41 & 0.44 & 0.58 & -0.18 & -0.31 & 0.08 & 0.33 & 1.80 & 1.76 & 1.75 \\
$46-50$ év & 1.25 & 1.19 & 1.19 & -0.44 & -0.30 & -1.04 & -0.03 & 0.36 & 0.60 & 1.80 & 1.76 & 1.75 \\
$51-55$ év & 0.86 & 0.80 & 0.80 & -1.97 & -1.84 & -2.57 & 0.45 & 0.84 & 1.09 & 1.80 & 1.76 & 1.75 \\
56-60 év & 0.18 & 0.12 & 0.12 & -4.61 & -4.48 & -5.20 & 1.28 & 1.68 & 1.93 & 1.80 & 1.76 & 1.75 \\
\hline összesen & 1.30 & 1.28 & 1.29 & 6.73 & 5.63 & $7.33^{1}$ & -0.18 & 0.15 & 0.38 & 1.80 & 1.76 & 1.75 \\
\hline \hline
\end{tabular}

8.2. táblázat: Termelékenységi profil becslése - alacsony képzettségüek

\begin{tabular}{|l|c|c|c|}
\hline \hline \multicolumn{3}{|c|}{ Függő változó: bruttó munkajövedelem logaritmusa } \\
\hline & Együttható & $\mathrm{z}$ & $\mathrm{P}>\mathrm{z}$ \\
\hline életkor & 0.071 & 9.37 & 0 \\
életkor ${ }^{2}$ & -0.004 & -3.71 & 0 \\
közép_du & -0.100 & -5.96 & 0 \\
nyugat_du & -0.115 & -6.94 & 0
\end{tabular}


8.2. táblázat: Termelékenységi profil becslése - alacsony képzettségüek, folyt.

\begin{tabular}{|l|c|c|c|}
\hline & Együttható & $\mathrm{z}$ & $\mathrm{P}>\mathrm{z}$ \\
\hline dél_du & -0.298 & -16.81 & 0 \\
észak_mo & -0.288 & -18.28 & 0 \\
észak_alföld & -0.328 & -21.92 & 0 \\
dél_alföld & -0.212 & -13.75 & 0 \\
év_1999 & 0.200 & 9.86 & 0 \\
év_2000 & 0.361 & 17.49 & 0 \\
év_2001 & 0.464 & 22.61 & 0 \\
év_2002 & 0.632 & 31.05 & 0 \\
év_2003 & 0.763 & 36.72 & 0 \\
év_2004 & 0.793 & 38.85 & 0 \\
év_2005 & 0.877 & 43.32 & 0 \\
év_2006 & 0.943 & 46.19 & 0 \\
év_2007 & 1.035 & 49.11 & 0 \\
év_2008 & 1.009 & 46.69 & 0 \\
konstans & 13.217 & 601.4 & 0 \\
\hline \hline Szelekciós egyenlet & \multicolumn{2}{|l}{} \\
\hline életkor & 0.090 & 7.44 & 0 \\
életkor ${ }^{2}$ & -0.025 & -16.05 & 0 \\
közép_du & 0.233 & 8.73 & 0 \\
nyugat_du & 0.274 & 10.28 & 0 \\
dél_du & 0.024 & 0.88 & 0.38 \\
észak_mo & -0.071 & -2.99 & 0.003 \\
észak_alföld & -0.040 & -1.76 & 0.078 \\
dél_alföld & -0.105 & -4.56 & 0 \\
év_1999 & 0.000 & -0.01 & 0.99 \\
év_2000 & -0.149 & -4.82 & 0 \\
év_2001 & -0.053 & -1.69 & 0.091 \\
év_2002 & 0.114 & 3.6 & 0 \\
év_2003 & 0.039 & 1.21 & 0.227 \\
\hline
\end{tabular}


8.2. táblázat: Termelékenységi profil becslése - alacsony képzettségüek, folyt.

\begin{tabular}{|l|c|c|c|}
\hline & Együttható & $\mathrm{z}$ & $\mathrm{P}>\mathrm{z}$ \\
\hline év_2004 & 0.092 & 2.91 & 0.004 \\
év_2005 & -0.027 & -0.87 & 0.382 \\
év_2006 & -0.003 & -0.08 & 0.935 \\
év_2007 & -0.016 & -0.49 & 0.626 \\
év_2008 & 0.013 & 0.4 & 0.692 \\
23 év alatti gy. & -0.082 & -10.47 & 0 \\
gyerek & -0.384 & -4.27 & 0 \\
egy. szülő.gy. & -0.303 & -2.95 & 0.003 \\
egyedülálló & -0.389 & -4.35 & 0 \\
élettárs & -0.304 & -3.49 & 0 \\
rokon & -0.672 & -7.19 & 0 \\
nappali tag. & -1.439 & -9.57 & 0 \\
nyugdíjas & -1.780 & -76.04 & 0 \\
nótlen & -0.120 & -1.35 & 0.178 \\
házas & -0.095 & -0.83 & 0.406 \\
özvegy & 0.249 & 2.42 & 0.015 \\
elvált & -0.005 & -0.06 & 0.956 \\
konstans & 0.940 & 7.86 & 0 \\
\hline mills lambda & -0.578 & -32.46 & 0 \\
\hline \hline
\end{tabular}

8.3. táblázat: Termelékenységi profil becslése - közepes képzettségüek

\begin{tabular}{|l|c|c|c|}
\hline \hline \multicolumn{3}{|c|}{ Függő változó: bruttó munkajövedelem logaritmusa } \\
\hline & Együttható & $\mathrm{z}$ & $\mathrm{P}>\mathrm{z}$ \\
\hline életkor & 0.149 & 14.56 & 0 \\
életkor ${ }^{2}$ & -0.014 & -9.27 & 0 \\
közép_du & -0.115 & -5.35 & 0 \\
nyugat_du & -0.141 & -6.6 & 0 \\
\hline
\end{tabular}


8.3. táblázat: Termelékenységi profil becslése - alacsony képzettségüek, folyt.

\begin{tabular}{|l|c|c|c|}
\hline & Együttható & $\mathrm{z}$ & $\mathrm{P}>\mathrm{z}$ \\
\hline dél_du & -0.265 & -10.71 & 0 \\
észak_mo & -0.226 & -11.28 & 0 \\
észak_alföld & -0.261 & -12.71 & 0 \\
dél_alföld & -0.238 & -11.78 & 0 \\
év_1999 & 0.179 & 5.97 & 0 \\
év_2000 & 0.301 & 9.82 & 0 \\
év_2001 & 0.419 & 13.66 & 0 \\
év_2002 & 0.570 & 19 & 0 \\
év_2003 & 0.708 & 24.32 & 0 \\
év_2004 & 0.729 & 24.94 & 0 \\
év_2005 & 0.808 & 28.26 & 0 \\
év_2006 & 0.840 & 29.57 & 0 \\
év_2007 & 0.842 & 29.4 & 0 \\
év_2008 & 0.894 & 29.7 & 0 \\
konstans & 13.457 & 452.74 & 0 \\
\hline \hline Szelekciós egyenlet & \multicolumn{2}{|l}{} \\
\hline életkor & 0.050 & 2.45 & 0.014 \\
életkor ${ }^{2}$ & -0.017 & -6.62 & 0 \\
közép_du & 0.170 & 4.56 & 0 \\
nyugat_du & 0.168 & 4.49 & 0 \\
dél_du & 0.003 & 0.07 & 0.946 \\
észak_mo & 0.066 & 1.95 & 0.051 \\
észak_alföld & 0.005 & 0.15 & 0.88 \\
dél_alföld & -0.030 & -0.9 & 0.368 \\
év_1999 & 0.046 & 0.9 & 0.368 \\
év_2000 & -0.172 & -3.39 & 0.001 \\
év_2001 & -0.187 & -3.69 & 0 \\
év_2002 & 0.088 & 1.71 & 0.088 \\
póüő év_2003 & -0.023 & -0.47 & 0.64 \\
\hline
\end{tabular}


8.3. táblázat: Termelékenységi profil becslése - alacsony képzettségüek, folyt.

\begin{tabular}{|l|c|c|c|}
\hline & Együttható & $\mathrm{z}$ & $\mathrm{P}>\mathrm{z}$ \\
\hline év_2004 & 0.027 & 0.55 & 0.581 \\
év_2005 & -0.034 & -0.69 & 0.489 \\
év_2006 & 0.009 & 0.19 & 0.852 \\
év_2007 & 0.091 & 1.84 & 0.066 \\
év_2008 & -0.014 & -0.28 & 0.78 \\
23 év alatti gy. & -0.031 & -2.13 & 0.033 \\
gyerek & -0.443 & -3.14 & 0.002 \\
egy.szülő.gy. & -0.364 & -2.17 & 0.03 \\
egyedülálló & -0.206 & -1.45 & 0.148 \\
élettárs & -0.082 & -0.59 & 0.555 \\
rokon & -0.410 & -2.7 & 0.007 \\
nappali tag. & -2.204 & -42.14 & 0 \\
nyugdíjas & -1.587 & -41.38 & 0 \\
nótlen & -0.004 & -0.02 & 0.983 \\
házas & -0.153 & -0.72 & 0.471 \\
özvegy & 0.091 & 0.44 & 0.658 \\
elvált & -0.210 & -1.15 & 0.249 \\
konstans & 1.011 & 4.59 & 0 \\
\hline \hline mills lambda & -0.582 & -26.48 & 0 \\
\hline
\end{tabular}

8.4. táblázat: Termelékenységi profil becslése - magas képzettségüek

\begin{tabular}{|c|c|c|c|}
\hline \multicolumn{4}{|c|}{ Függó változó: bruttó munkajövedelem logaritmusa } \\
\hline & Együttható & $\mathrm{z}$ & $\mathrm{P}>\mathrm{Z}$ \\
\hline életkor & 0.208 & 13.56 & 0 \\
\hline életkor ${ }^{2}$ & -0.018 & -9.07 & 0 \\
\hline közép_du & -0.224 & -7.51 & 0 \\
\hline nyugat_du & -0.182 & -5.91 & 0 \\
\hline
\end{tabular}


8.4. táblázat: Termelékenységi profil becslése - alacsony képzettségüek, folyt.

\begin{tabular}{|l|c|c|c|}
\hline & Együttható & $\mathrm{z}$ & $\mathrm{P}>\mathrm{z}$ \\
\hline dél_du & -0.329 & -9.77 & 0 \\
észak_mo & -0.292 & -9.99 & 0 \\
észak_alföld & -0.223 & -7.93 & 0 \\
dél_alföld & -0.367 & -13.48 & 0 \\
év_1999 & 0.077 & 1.64 & 0.101 \\
év_2000 & 0.289 & 6.1 & 0 \\
év_2001 & 0.428 & 8.99 & 0 \\
év_2002 & 0.597 & 12.9 & 0 \\
év_2003 & 0.764 & 18.41 & 0 \\
év_2004 & 0.850 & 20.5 & 0 \\
év_2005 & 0.872 & 21.62 & 0 \\
év_2006 & 0.900 & 22.31 & 0 \\
év_2007 & 0.948 & 23.02 & 0 \\
év_2008 & 0.982 & 22.95 & 0 \\
konstans & 13.836 & 299.54 & 0 \\
\hline \hline Szelekciós egyenlet & \multicolumn{2}{|l}{} \\
\hline életkor & -0.012 & -0.4 & 0.687 \\
életkor ${ }^{2}$ & -0.009 & -2.38 & 0.017 \\
közép_du & 0.219 & 4.21 & 0 \\
nyugat_du & 0.192 & 3.57 & 0 \\
dél_du & 0.011 & 0.19 & 0.85 \\
észak_mo & 0.155 & 3.11 & 0.002 \\
észak_alföld & 0.212 & 4.31 & 0 \\
dél_alföld & 0.186 & 3.93 & 0 \\
év_1999 & 0.159 & 2 & 0.046 \\
év_2000 & -0.132 & -1.7 & 0.089 \\
év_2001 & -0.320 & -4.21 & 0 \\
év_2002 & 0.072 & 0.92 & 0.356 \\
év_2003 & 0.033 & 0.47 & 0.636 \\
\hline
\end{tabular}


8.4. táblázat: Termelékenységi profil becslése - alacsony képzettségüek, folyt.

\begin{tabular}{|l|c|c|c|}
\hline & Együttható & $\mathrm{z}$ & $\mathrm{P}>\mathrm{z}$ \\
\hline év_2004 & 0.043 & 0.61 & 0.541 \\
év_2005 & 0.049 & 0.72 & 0.469 \\
év_2006 & 0.082 & 1.2 & 0.231 \\
év_2007 & 0.078 & 1.13 & 0.26 \\
év_2008 & 0.085 & 1.17 & 0.242 \\
23 év alatti gy. & -0.039 & -2.28 & 0.023 \\
gyerek & -0.106 & -0.61 & 0.544 \\
egy.szülő.gy. & 0.789 & 3.89 & 0 \\
egyedülálló & 0.326 & 1.91 & 0.056 \\
élettárs & 0.348 & 2.05 & 0.041 \\
rokon & 0.006 & 0.03 & 0.974 \\
nappali tag. & -1.704 & -15.72 & 0 \\
nyugdíjas & -1.470 & -30.33 & 0 \\
nótlen & 0.315 & 1.86 & 0.063 \\
házas & 0.677 & 3.14 & 0.002 \\
özvegy & 0.387 & 1.88 & 0.06 \\
elvált & 0.130 & 0.76 & 0.446 \\
konstans & 0.380 & 1.65 & 0.099 \\
\hline mills lambda & -0.742 & -21.08 & 0 \\
\hline \hline
\end{tabular}




\section{F.2. A háztartás feladatának megoldása}

A feltételes optimalizálási feladathoz rendelt Lagrange-függvény a következớ2

$$
\begin{aligned}
& \mathcal{L}\left(c_{t+j-1, j}, l_{t+j-1, j}, \lambda_{j}, \mu_{j}, \theta_{j}\right)=\sum_{j=1}^{J} \beta^{j-1} \psi_{t+j-1, j}\left(\frac{c_{t+j-1, j}^{1-\sigma}}{1-\sigma}-\gamma \frac{l_{t+j-1, j}^{1+\xi}}{1+\xi}\right)+ \\
& +\sum_{j=1}^{J_{1}} \lambda_{j}\left(\begin{array}{c}
\left(1+r_{t+j-1}\left(1-\tau_{k}\right)\right)\left(a_{t+j-1, j}+B e q_{t+j-1} / N_{t+j-1}\right)+z_{t+j-1, j}+ \\
+\left(1-\tau_{l}-\tau_{P A Y G}\right) w_{t+j-1} e_{j} l_{t+j-1, j}-a_{t+j, j+1}-\left(1+\tau_{c, t+j-1}\right) c_{t+j-1, j}
\end{array}\right)+ \\
& +\sum_{j=J_{1}+1}^{J} \mu_{j}\left(\begin{array}{c}
\left(1+r_{t+j-1}\left(1-\tau_{k}\right)\right)\left(a_{t+j-1, j}+B e q_{t+j-1} / N_{t+j-1}\right)+ \\
+b_{t-j+J_{1}+1, J_{1}+1} G_{t, t-j+J_{1}+1}^{(1-v)}-a_{t+j, j+1}-\left(1+\tau_{c, t+j-1}\right) c_{t+j-1, j}
\end{array}\right)+ \\
& +\sum_{j=1}^{J_{1}} \theta_{j}\left(b_{t+j, j+1}-g_{t+j}\left(b_{t+j-1, j}-\alpha\left(1-\tau_{l}-\tau_{b}\right) w_{t+j-1} e_{j} l_{t+j-1, j} / J_{1}\right) .\right.
\end{aligned}
$$

A fogyasztás szerinti elsô rendű feltétel

$$
\frac{\partial \mathcal{L}}{\partial c_{t+j-1, j}}=\beta^{j-1} \psi_{t+j-1, j} c_{t+j-1, j}^{-\sigma}-\lambda_{j}\left(1+\tau_{c, t+j-1}\right)=0
$$

akkor ha $1 \leq j \leq J_{1}$ és

$$
\frac{\partial \mathcal{L}}{\partial c_{t+j-1, j}}=\beta^{j-1} \psi_{t+j-1, j} c_{t+j-1, j}^{-\sigma}-\mu_{j}\left(1+\tau_{c, t+j-1}\right)=0
$$

ha $J_{1}+1 \leq j \leq J$. A két összefüggésból kifejezhetô a Lagrange-multiplikátorok értéke: $\lambda_{j}=\beta^{j-1} \psi_{t+j-1, j} c_{t+j-1, j}^{-\sigma} \frac{1}{\left(1+\tau_{c, t+j-1}\right)}$, illetve $\mu_{j}=\beta^{j-1} \psi_{t+j-1, j} c_{t+j-1, j}^{-\sigma} \frac{1}{\left(1+\tau_{c, t+j-1}\right)}$.

A pénzügyi vagyon szerinti elsô rendú feltételre kapjuk a Lagrange-függvény deriválásából, hogy

$$
\frac{\partial \mathcal{L}}{\partial a_{t+j, j+1}}=-\lambda_{j}+\lambda_{j+1}\left(1+r_{t+j}\left(1-\tau_{k}\right)\right)=0,
$$

akkor ha $1 \leq j<J_{1}$ és

$$
\frac{\partial \mathcal{L}}{\partial a_{t+j, j+1}}=-\mu_{j}+\mu_{j+1}\left(1+r_{t+j}\left(1-\tau_{k}\right)\right)=0
$$

\footnotetext{
${ }^{2} \mathrm{Az}$ adózás utáni kamatláb értékére a $r_{\tau}=\left(1-\tau_{k}\right) r$ jelölést vezettük be.
} 
lesz, ha $J_{1}+1 \leq j \leq J$. A harmadik eset akkor áll elő, ha $j=J_{1}$. Ilyenkor

$$
\frac{\partial \mathcal{L}}{\partial a_{t+J_{1}, J_{1}+1}}=-\lambda_{J_{1}}+\mu_{J_{1}+1}\left(1+r_{t+j}\left(1-\tau_{k}\right)\right)=0 .
$$

Mindhárom összefüggésból azt kapjuk, hogy bármely két egymást követô időszakban fenn kell állnia, hogy

$$
\frac{c_{t+j, j+1}}{c_{t+j-1, j}}=\left\{\beta\left(1+r_{t+j}\left(1-\tau_{k}\right)\right) \frac{\psi_{t+j, j+1}}{\psi_{t+j-1, j}} \frac{1+\tau_{c, t+j-1}}{1+\tau_{c, t+j}}\right\}^{1 / \sigma} .
$$

Az optimális döntési pálya minden eleme felírható $c_{t, 1}$ függvényeként

$$
c_{t+j-1, j}=\left\{\left[\beta\left(1+r_{t+j}\left(1-\tau_{k}\right)\right)\right]^{t-1} \psi_{t+j-1, j} \frac{1+\tau_{c, t+j}}{1+\tau_{c, t}}\right\}^{1 / \sigma} c_{t, 1}
$$

A munkakínálat meghatározásához tekintsük a Lagrange-függvény $l_{t+j-1, j}$ szerinti deriváltját az elsố életszakaszra.

$$
\begin{aligned}
& \frac{\partial \mathcal{L}}{\partial l_{t+j-1, j}}=\gamma \beta^{j-1} \psi_{t+j-1, j} l_{t+j-1, j}^{\xi}-\lambda_{j}\left(1-\tau_{l}-\tau_{b}\right) w_{t+j-1} e_{j}+ \\
& +\theta_{j} g_{t+j} \alpha\left(1-\tau_{l}-\tau_{b}\right) w_{t+j-1} e_{j} / J_{1}=0
\end{aligned}
$$

ha $1 \leq j \leq J_{1}$. Behelyettesítve $\lambda_{j}$-t és a kifejezést némileg átrendezve kapjuk, hogy a munkakínálat nagysága ekkor

$$
l_{t+j-1, j}=\left[\frac{w_{t+j-1} e_{j}}{\gamma}\left(\frac{1-\tau_{l}-\tau_{b}}{1+\tau_{c, t+j-1}} c_{t+j-1, j}^{-\sigma}-\frac{\theta_{j} g_{t+j} \alpha\left(1-\tau_{l}-\tau_{b}\right)}{\beta^{t-1} \psi_{t+j-1, j} J_{1}}\right)\right]^{1 / \xi}
$$

alakban lesz megadható. Az ismeretlen $\theta_{j}$ Lagrange együttható értékét a Lagrangefüggvény $b_{t+j, j+1}$ szerinti deriválásával határozhatjuk meg a következók szerint:

$$
\frac{\partial \mathcal{L}}{\partial b_{t+j, j+1}}=\theta_{j}-\theta_{j+1} g_{t+j+1}=0
$$

akkor, ha $1 \leq t \leq J-1$ és

$$
\frac{\partial \mathcal{L}}{\partial b_{T_{1}+T_{2}+1}}=\theta_{J_{1}}+\mu_{J_{1}+1}=0
$$


Függelék

Utóbbiból kapjuk, hogy $\theta_{J_{1}}=-\mu_{J_{1}+1}$. A Lagrange-együtthatók utolsó időszaki értékéból nyerjük $\theta_{J_{1}}$-t, az $\theta_{j}$ sorozatának korábbi elemei pedig egyszerúen adódnak, hiszen

$$
\begin{aligned}
& \theta_{J_{1}}=-\mu_{J_{1}+1}=-\beta^{J_{1}} \psi_{t+J_{1}, J_{1}+1} c_{t+J_{1}, J_{1}+1}^{-\sigma} \frac{1}{\left(1+\tau_{c, t+J_{1}}\right)} \\
& \theta_{J_{1}}=\theta_{J_{1}-1} / g_{t+J_{1}}=\theta_{J_{1}-2} /\left\{g_{t+J_{1}} g_{t+J_{1}-1}\right\}=\ldots=\theta_{1} /\left\{g_{t+J_{1}} g_{t+J_{1}-1} \ldots g_{t+1}\right\}
\end{aligned}
$$

A $\theta_{j}$ értékek behelyettesítése és egy kis átrendezés után kapjuk a második életszakasz munkakínálatát3

$$
l_{t+j-1, j}=\left[\frac{w_{t+j-1} e_{j}}{\gamma}\left(\frac{1-\tau_{l}-\tau_{b}}{1+\tau_{c, t+j-1}} c_{t+j-1, j}^{-\sigma}+\beta^{J_{1}-j-1} \frac{\psi_{t+J_{1}, J_{1}+1}}{\psi_{t+j-1, j}} \frac{G_{t+J_{1}, t+j-1} \alpha\left(1-\tau_{l}-\tau_{b}\right) c_{t+J_{1}, J_{1}+1}^{-\sigma}}{\left(1+\tau_{c, t+J_{1}}\right) J_{1}}\right)\right]^{1 / \xi}
$$

Láttuk, hogy a késóbbi fogyasztások felírhatók az elsô idôszaki fogyasztás, exogén változók és paraméterek függvényében (8.1. egyenlet), és hogy mindkét életszakasz munkakínálata is megadható (adott reálbér és reálkamatláb mellett) a fogyasztások, exogén változók és paraméterek függvényében (8.6. egyenlet). Ugyanakkor a fogyasztás, a munkakínálat és az ezektôl függő nyugdíj értékeinek ki kell elégíteniük a fogyasztó intertemporális költségvetési korlátját:

$$
\sum_{j=1}^{J} R_{t, t+j-1}\left(1+\tau_{c, t+j-1}\right) c_{t+j-1, j}=\sum_{j=1}^{J} R_{t+j-1, j}\left(\left(1-\tau_{l}-\tau_{b}\right) w_{t} e_{t+j-1, j} l_{t+j-1, j}+b_{t+j-1, j}\right) .
$$

Mivel a 8.7. egyenletben a fogyasztás, a munkakínálat és az induló nyugdíj értékeit is fel tudjuk írni (adott reálbér és reálkamatláb mellett) az elsô idôszaki fogyasztás függvényeként, ezért az egyenletnek egyetlen ismeretlenje marad: $c_{t, 1}$. Ennek értékét numerikus módszerekkel meghatározhatjuk, amelynek ismeretében a háztartások többi endogén változójának pályáját is ki tudjuk számolni.

\footnotetext{
${ }^{3}$ A disszertáció 3 fejezetének modelljében az elsó életszakasz nettó keresetei nem részei a kezdő nyugdíjat meghatározó képletnek, ezért ezen évek munkakínálatát nem is ösztönzi a késốbbi nyugdíjhoz való hozzájárulása. Ezekben az években így a munkakínálati függvény nem tartalmazza a jobb oldali kifejezés második tagját.
} 


\section{F.3. Az együttélő korosztályok modelljének normált egyenletei}

A függelék a modell megoldásához szükséges egyenletek technológiai szinttel normált változatait tartalmazza. A normált változókban már létezik a modellnek állandósult állapota, melyet a szimuláció nyitó és záró stacionárius állapotaként használtunk. A fajlagos változókat az eredeti változók $\widetilde{x_{t}}=\frac{x_{t}}{A_{t}}$ átalakításaként állítom elő.

A fogyasztó költségvetési korlátja munkaképes korban:

$$
\widetilde{a}_{t+1, j+1}(1+\lambda)+\widetilde{c}_{t, j}+\widetilde{T} a x_{t, j}=\left(1+r_{t}\right)\left(\widetilde{a}_{t, j}+\widetilde{B e q_{t}} / N_{t}\right)+\widetilde{w}_{t} e_{j} l_{t, j}
$$

A fogyasztó nettó adóbefizetései $j$ évesen :

$$
\widetilde{\operatorname{Tax}}_{t, j}=\tau_{c} \widetilde{c}_{t, j}+\tau_{k} r_{t}\left(\widetilde{a}_{t, j}+\widetilde{B e q_{t}} / N_{t}\right)+\left(\tau_{l}+\tau_{b}\right) \widetilde{w}_{t} e_{j} l_{t, j}-\widetilde{z}_{t, j}
$$

A fogyasztó költségvetési korlátja nyugdíjas korban:

$$
\widetilde{a}_{t+1, j+1}(1+\lambda)+\widetilde{c}_{t, j}+\widetilde{\operatorname{Tax}}_{t, j}=\left(1+r_{t}\right)\left(\widetilde{a}_{t, j}+\widetilde{B e q}_{t} / N_{t}\right)+\widetilde{b}_{t, j}
$$

A fogyasztó fogyasztásának növekedése $j$ és $j+1$ éves kora között:

$$
\widetilde{c}_{t+1, j+1}\left(1+\tau_{c, t+1}\right)(1+\lambda) \psi_{j, t+j-1}=\left[\beta\left(1+r_{t+1}\left(1-\tau_{k}\right)\right)\right] \psi_{j+1, t+j} \widetilde{c}_{t, j}\left(1+\tau_{c, t}\right)
$$

A fogyasztó munkakínálata $j$ évesen:

$$
l_{t+j-1, j}=\left[\frac{\widetilde{w}_{t+j-1} e_{j}}{\gamma}\left(\frac{1-\tau_{l}-\tau_{b}}{1+\tau_{c, t+j-1}} \widetilde{c}_{t+j-1, j}^{-1}+\beta^{J_{1}-j-1} \frac{\psi_{t+J_{1}, J_{1}+1}}{\psi_{t+j-1, j}} \frac{\widetilde{G}_{t+J_{1}, t+j-1} \alpha\left(1-\tau_{l}-\tau_{b}\right) \widetilde{c}_{t+J_{1}, J_{1}+1}^{-1}}{\left(1+\tau_{c, t+J_{1}}\right) J_{1}}\right)\right]^{1 / \xi}
$$

ahol $\widetilde{G}$ az átlagos hatékonysági egységre jutó nettó reálbérek kummulált növekedési tényezője.

A fogyasztó intertemporális költségvetési korlátja:

$$
\sum_{j=1}^{T} R_{t, j}\left(1+\tau_{c, t+j-1}\right) \widetilde{c}_{t+j-1, j}=\sum_{j=1}^{T} R_{t, j}\left(\left(1-\tau_{l}-\tau_{b}\right) \widetilde{w}_{t} e_{j} l_{t+j-1, j}+\widetilde{b}_{t+j-1, j}\right)
$$


A fogyasztó társadalombiztosítási járuléka $j$ évesen:

$$
\widetilde{T B}_{t, j}^{b}=\tau_{b} \widetilde{w}_{t} e_{j} l_{t, j}
$$

A 'nyugdíjfelhalmozási' egyenlet:

$$
\widetilde{b}_{t+1, j+1}^{J_{1}+1}=\widetilde{g}_{t+1}\left[\widetilde{b}_{t, j}^{J_{1}+1}+\frac{\alpha\left(1-\tau_{l}-\tau_{b}\right) \widetilde{w}_{t} e_{t, j} l_{t, j}}{J_{1}}\right],
$$

ahol $\widetilde{g}$ az átlagos hatékonysági egységre jutó nettó reálbérek növekedési tényezője.

A nyugdíjindexálás képlete:

$$
\widetilde{b}_{t, j}=\widetilde{b}_{t+J_{1}+1-j, J_{1}+1} G_{t, t-j+J_{1}+1}^{1-v}(1+\lambda)^{-v\left(j-J_{1}-1\right)}
$$

A vállalat termelési függvénye a $t$ időszakban:

$$
\widetilde{Y}_{t}=\widetilde{K}_{t}^{\varepsilon} L_{t}^{1-\varepsilon}
$$

A vállalat tőke- és munkakeresleti függvénye a $t$ idôszakban:

$$
\begin{aligned}
\varepsilon\left[\widetilde{K}_{t} / L_{t}\right]^{\varepsilon-1} & =r_{t}^{K} \\
(1-\varepsilon)\left[\widetilde{K}_{t} / L_{t}\right]^{\varepsilon} & =\widetilde{w}_{t}
\end{aligned}
$$

Az állam költségvetési korlátja a $t$ időszakban:

$$
\widetilde{G o v}_{t}+\left(1+r_{t}\right) \widetilde{B}_{t}^{g}+\widetilde{P}_{t}=\sum_{j=1}^{J} \widetilde{\operatorname{Tax}_{t, j}} N_{t, j}+\widetilde{B}_{t+1}^{g}(1+\lambda)
$$

Az összes örökség értéke a $t$ időszakban:

$$
\widetilde{B e q_{t}}=\sum_{j=1}^{J}\left(1-s_{t, j}\right) N_{t-1, j-1} \widetilde{a}_{t, j}
$$

Az összes társadalombiztosítási járulék értéke a $t$ idôszakban:

$$
\widetilde{T}_{t, j}^{b}=\sum_{j=1}^{J_{1}} \tau_{b} \widetilde{w}_{t} e_{j} l_{t, j} N_{t, j}
$$


Az összes kifizetett nyugdíj értéke a $t$ idôszakban:

$$
\widetilde{P}_{t}=\sum_{j=J_{1}+1}^{J} \widetilde{b}_{t, j} N_{t, j}
$$

A nyugdíjkassza GDP-arányos egyenlege a $t$ időszakban:

$$
\frac{\widetilde{S}_{t}^{b}}{\widetilde{Y}_{t}}=\frac{\widetilde{T}_{t}^{b}-\widetilde{P}_{t}}{\widetilde{Y}_{t}}
$$

Jelöljük $n_{t, j}$-vel a $t$ időpontban a $j$ korosztály létszámának részesedését a teljes népességéből: $n_{t, j}=\frac{N_{t, j}}{N_{t}}$ ! Ekkor a háztartások hatékony före jutó fogyasztásának értéke a $t$ idôszakban:

$$
\widetilde{C}_{t}=\sum_{j=1}^{J} \widetilde{c}_{t, j} n_{t, j}
$$

A háztartások hatékony fốre jutó vagyonának értéke a $t$ időszakban:

$$
\widetilde{\text { Asset }}_{t+1}=\sum_{j=1}^{T} \widetilde{a}_{t+1, j+1} n_{t, j}
$$

A tókefelhalmozási egyenlet a $t$ idôszakban:

$$
\widetilde{I}_{t}=\widetilde{K}_{t+1}(1+\lambda)-(1-\delta) \widetilde{K}_{t}
$$

A reálkamatláb értéke a $t$ időszakban:

$$
r_{t+1}=r^{*}+\left(e^{-\omega(1+\lambda) \widetilde{B_{t+1}} f} / \widetilde{Y}_{t}-1\right) .
$$

Árupiaci egyensúlyi feltétel a $t$ idôszakban:

$$
\widetilde{C}_{t}+\widetilde{I}_{t}+\widetilde{G o v}_{t}+\widetilde{N X}_{t}=\widetilde{Y}_{t}
$$

A vagyoneszközök piacának egyensúlya a $t$ időszakban:

$$
\widetilde{\text { Asset }}_{t+1}=\widetilde{K}_{t+1}+\widetilde{B}_{t+1}^{g}+\widetilde{B}_{t+1}^{f}
$$


A külföldi vagyon változását mutató egyenlet a $t$ időszakban:

$$
\widetilde{B}_{t+1}^{f}(1+\lambda)-\left(1+r_{t}\right) \widetilde{B}_{t}^{f}=\widetilde{N X}_{t}
$$

\section{F.4. Az effektív munka, a hatékony fôre jutó fo- gyasztás és vagyon dekompozíciójának módszer- tana}

Az egy fôre jutó hatékony munkaórák számának változása dekompozíció segítségével felbontható:

$$
\begin{aligned}
\Delta\left\{\frac{L_{t+1}}{N_{t+1}}\right\}= & \Delta\left\{\frac{L_{t+1}}{N 60_{t+1}} \frac{N 60_{t+1}}{N_{t+1}}\right\}= \\
= & \left\{\frac{N 60_{t}}{2 N_{t}}+\frac{N 60_{t+1}}{2 N_{t+1}}\right\} \Delta \frac{L_{t+1}}{N 60_{t+1}}+\left\{\frac{L_{t}}{2 N 60_{t}}+\frac{L_{t+1}}{2 N 60_{t+1}}\right\} \Delta \frac{N 60_{t+1}}{N_{t+1}}= \\
= & \left\{\frac{N 60_{t}}{2 N_{t}}+\frac{N 60_{t+1}}{2 N_{t+1}}\right\} \Delta \sum_{j=1}^{J_{1}} e_{j} l_{t, j} n_{t, j}+\left\{\frac{L_{t}}{2 N 60_{t}}+\frac{L_{t+1}}{2 N 60_{t+1}}\right\} \Delta n_{60_{t+1}}= \\
= & \left\{\frac{N 60_{t}}{2 N_{t}}+\frac{N 60_{t+1}}{2 N_{t+1}}\right\} \sum_{j=1}^{J_{1}} e_{j}\left(\frac{n_{t, j}+n_{t+1, j}}{2}\right) \Delta l_{t, j}+ \\
& +\left\{\frac{N 60_{t}}{2 N_{t}}+\frac{N 60_{t+1}}{2 N_{t+1}}\right\} \sum_{j=1}^{J_{1}} e_{j}\left(\frac{l_{t, j}+l_{t+1, j}}{2}\right) \Delta n_{t, j}+ \\
& +\left\{\frac{L_{t}}{2 N 60_{t}}+\frac{L_{t+1}}{2 N 60_{t+1}}\right\} \Delta n_{60_{t+1}},
\end{aligned}
$$

ahol $N 60_{t}$ a 60 évnél fiatalabb népesség létszáma a $t$ időszakban, $n 60_{t, j}$ az $j$ korosztály aránya a 60 évnél fiatalabbak között a $t$ idôszakban $\left(\Delta n_{60_{t+1}}\right.$ ennek a változása). Az egy fốre jutó hatékony munkaórák számának változását a felbontás szerint három tényezô befolyásolja: a három tagból az elsố az egyes korosztályok effektív munkaóráinak változásából, a második a 60 év alatti népesség szerkezetének változásából, a harmadik a 60 év alatti népesség arányának változásából eredő hatást mutatja. A dekompozíciót átlagos súlyozással végeztük el. 
A hatékony főre jutó fogyasztás és vagyon és dekompozíciójánál $\left(X_{t}=C_{t}\right.$, Asset $_{t}$ ) a felbontás valamivel egyszerúbb, hiszen csak a viselkedés megváltozásának hatását és a népesség szerkezetének változásából eredő hatást különíti el:

$$
\Delta\left\{\frac{X_{t+1}}{N_{t+1}}\right\}=\sum_{j=1}^{J_{1}+J_{2}}\left(\frac{n_{t, j}+n_{t+1, j}}{2}\right) \Delta x_{t, j}+\sum_{j=1}^{J_{1}+J_{2}}\left(\frac{x_{t, j}+x_{t+1, j}}{2}\right) \Delta n_{t, j}
$$

ahol $x_{t, j}$ az $j$ korosztály adott $\left(x_{t, j}=c_{t, j}, a_{t, j}\right)$ endogén változója a $t$ időszakban. 